
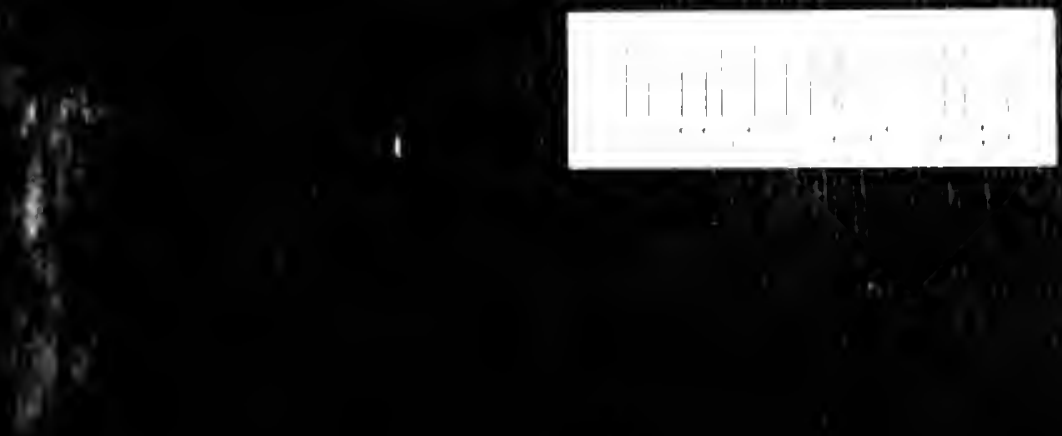

als 4

4 


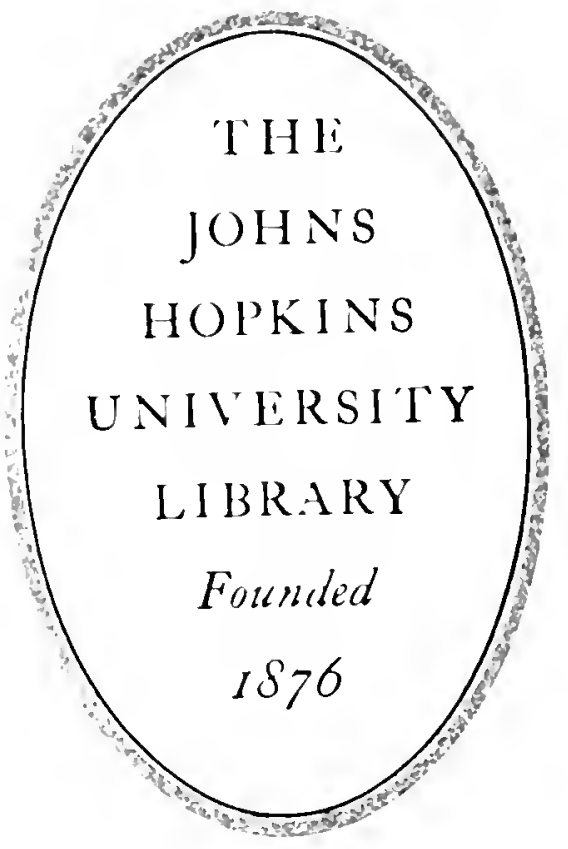






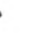




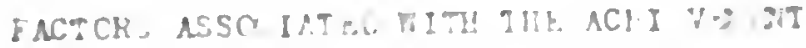

CF

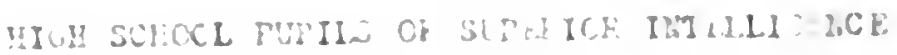

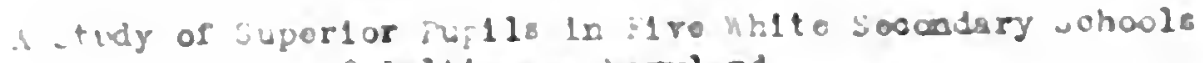
of beltimore, baryland

by

Jotan K. Musselan

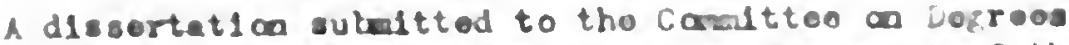
of astar of Eduoation an: jootor of Eduantlon of the Joke isopklas unlversity in canforalby with tha rom quireseat of the cogrso of Dxotor of Fiducatian. 

To Ily wife 

ACYNOH.L.IX:L:LITS

The a uthor gratofully aoknowledper his indobtodness to the merbors of his diseortation oomitteer Dr. J. ''. Stephent. Dr. Arthur I.1chtenstoln, and Dr. Lawronoo RigEs. Ho wishes nloo to nobnowlodgo tho Inepirint assistanoo and cooperation of Dr. Florenco L. Pamberfor, Dr. David k.

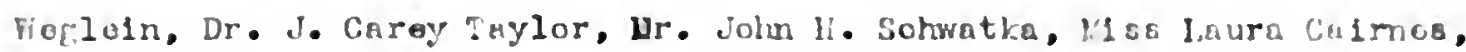

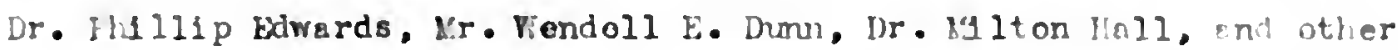
principals and counsellors without whose permission and aseistanou this study would never heve boen completed.

The oheorful cooporation of the many stucents und faculty of the vite Baltimore ochools in fiving thoir time und best efforta wa an Invaluable oontribution to this study.

No one more then the author know and appreolates what ho owes the many asaoclates and authors in the Johns fiopkins Scrinary, who ivith their lonowledgo, constructive ortiolsm and active assiatanco have mouldod this disortation to its final form.

The asistanoe of Conotanoo forler, Adolph Sellpman. Roelnu Doture, Dorothy Nurphy and John C. Brums in proparation of the Eanueorlpt has boen noterorthy 


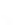


TABLE OF CONTENTS

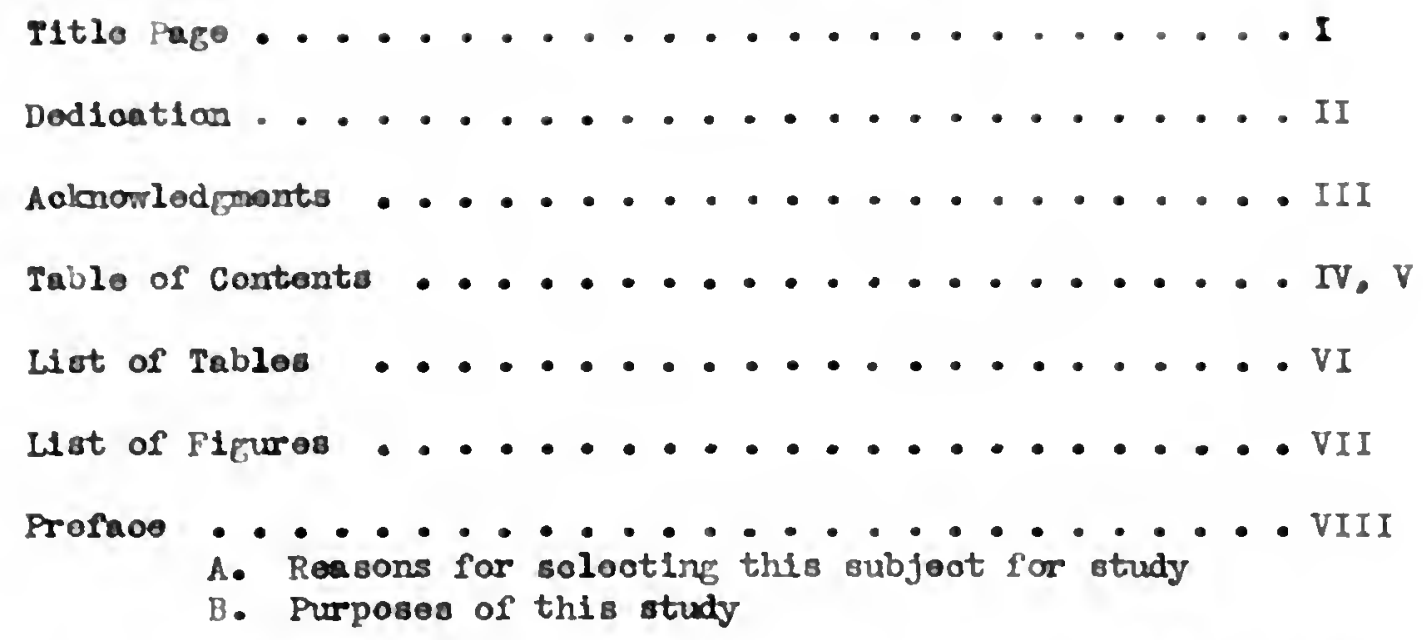

I. Previous Studias of Superior Individualo and Groups who Do llot Aahlevo Up to Their Capacitios.

A. Studios of Individuals

B. The rolation botwoon achievoment of groums and relatod variablos inoluding: (1) antooodonts' country of birth, (2) fanily rolationships, (3) foreign languages spokon in the homo. (4) hoalth, (5) how disolplino, (6) parents' oducation, (7) personality. (B) sibling roletionshipo, (9) 8120 of fanily, (10) sociomoconomio status, (11) study habits.

C. Provisions for superior pupils

D. Summary of Provious Studios

E. Tho Rolation of this Study to Previous Studias

II. Seloction of cases and Colloction of Data on the Cases Studiod.. A. Selootion of casos for tho study

(1) Population fros whioh the cases wore seloctad

(2) Critarion of intelliganos for solootion of cases

3. Collection of data on tho casos studied

(1) Hoesures of intoll1gonos, achlovomant, personal1ty, atudy habits, sociomoononio status, hoalth and physical defeots, genoral questionaloe, and sohool rocordi.

III. Treatmont of tho Data . . . . . . . . . . . . . .

A. Compilation of a mator chart inoludins a.ll data

B. Calculation of the achiovement ratio

C. The mothod usod in oosperting the achiovanent ratio with each varlablo

(1) Division into achiovemont ratio froups for comperison

(2) Graphio represontation of rolationohips of aohioroment ratioa to oach varlablo 



\section{TABLF, OF COITENTS (Con't.)}

IV. Data on Achioranont of Thoso Superior Pupila ......... A. Aahioranent Tosts

B. Uantal Ago

C. Intelligono Quotionto

D. Sahool karko

E. Sohool Rotardation

F. Sohool 100oloration

V.The Rolation of Aahlovonont Ratio to Paraonality Toat Scoros... A. The rolation of sooros on tho Machburno SoolalAdjustment Irvontory" to the achlevemont ratio

(1) trutheulnose

(2) happinoos

(3) aliontion

(4) sympathy

(5) purposo

(6) inpulso-judgnont

(7) control

(8) Tashbourno S-A Inventory Total Scoros

B. The relation of scoros on the "Link Invontary of Activitios and Interests" to achiovament ratio ...... (1) social initiativo

(2) solf-detornination

(3) oconosic solf-dotorination

(4) adjustmont to tho opposito $80 x$

(5) ovorall personality quotient

c. Surmary

VI. The Relation of Hane Baokgrounds to Achlevemont Rat1o.....

A. Sins Soolo-Econaric Status

B. Forelgn lanfuages spokon in the homo

C. lhuber of Anarlaan Born Grandparonto

D. Antocodent B' country of birth

E. Fathars' oducation

F. Mothars' aducation

G. Hember of Slblings in the Family

II. Sibling position in tho Fendly

I. Environenont - Urban vo. Rural

J. Family residonoo - Brokon or Intact Panily

K. Pup11s, Ilaelth

L. Parents' Health

4. Pupilo' Phyoloal Dofooto

11. Ilumo Disoiplino

0. Parents vrorking

P. Study habits

VII. Conolusions . . . . . . . . . . . . . . . .

A. Stemary of tho rolationshipo found botwoon

aohiovonont ratio and tho cosporimontal variablos

B. Inplications lor furthor rozoaroh

C. Bibliography 
• 


\section{LIST OF' TAHLBS}

Table No.

Intelligonoe of Pupl1s by Sohools..............

Distribution of Puplls by Grade and Level of

Distribution of Achiovement Ratios by Sohools,

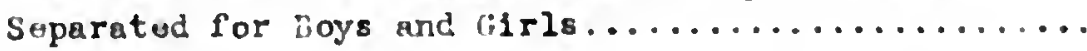

D18tribution of lyor-Ruch Achiovement Standard Soores for 297 Pupl 18 of Suporior Intelligonoe

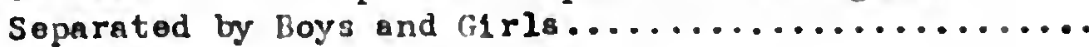

Distribution of Mental Ages in Monthe, Soparated

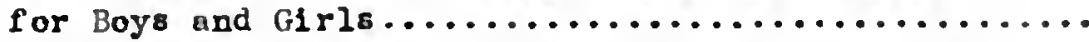

D1stribution of ot16 I.Q'B, Soparated for Boys

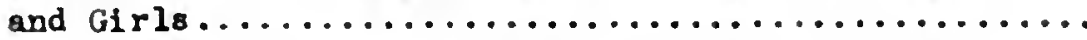

Distribution of Hennon-lielson I.Q.18, Separatod

for Boys and Girls........................

Distribution of Achi evement Ratios for Boys.

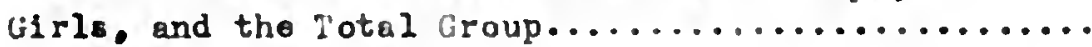

Diatribution of General Sohlorship Avorages for the Semester Completed Preceding the Investigation,

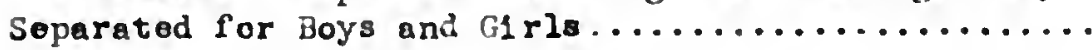

Distribution of Unsatis factory Semoster Conduot Mark Reoelved in High Sohool, Separated for

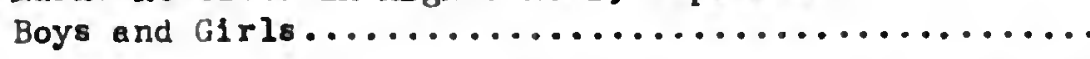

Distribution of the Number of Senester Falled in Hifh Sohool, Separated for Boys and Cirls........

Distribution of the Number of Senestors Skippod Throughout Attendanco in all Sohools, Separated

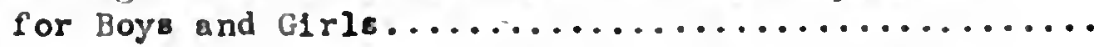


. 
Distribution Showlne, the rinlution of

Aohl overient Ratios to Washburno l'uuthfulnoss

Scores 1 trine the linurs for Boys and (iirls

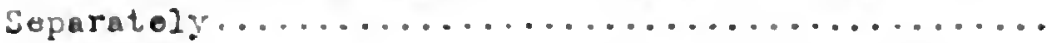

16

If stribution Showlng the fulution of hohisurment

kintlos to Yashbumo Hepinoss Scorus fivin the

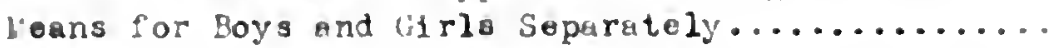

ob

17

Distribution Showing, the Relation of Achleverient

Latios to Fias!hurno Alienation Scores Rivinp the

Lewrs for Boys ard firls Seperatoly.............

90

18

Distribution Showing, the Rolation of Achlevenerit

retios to Wishburno Sympathy scoros giving the

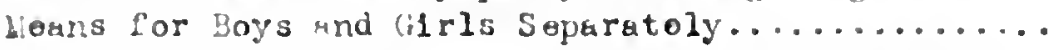

94

19

Distribution Showine, the kelation of Achi everient

Ratios to Wiashburne purpose scores..............

Distribution Showing the kelation of Achlerement Rat1 os to Weshburne Impulse Judgment scores.......

Distributian Showlne the kelation of Achievement

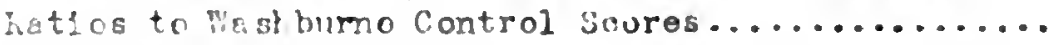

Detribution Shorlne tho Ralution of fichlevement

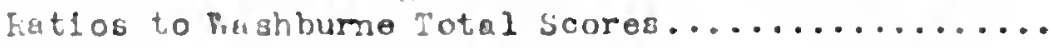


LIST OH MILES (Continuod)

Table lio.

Iago

28

Distribution Showing the Rolation of Achiovenont

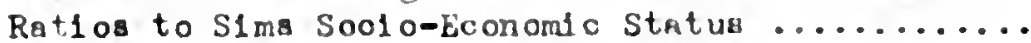

140

29

Distribution of Achiovomont Fiatios Aocording

to Forelgn Lnnguager Spoken in tho llose..........

144

\$o

Distribution of Achievament Ratios According

to Number of Anerioan Born Grandparonts..........

Distribution of Achievoment Ratios Aooording

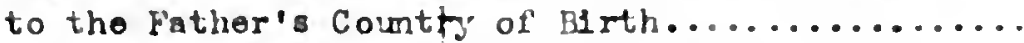

DA otribution of Achi evement Ratios Acjording

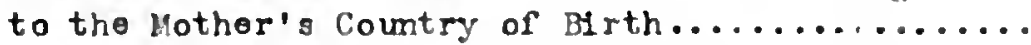

Distribution of Achievement Retios nocording

to Fathor's Father's Country of B1rth............

Distribution of Achievement Ratios According

to the Father's l'other's Country of B1rth........

162

Distribution of Achi evenont Ratiog According

to the l'other's Father's Country of B1rth.........

Distribution of Achievemont Katios According

to Nother's liothor's Country of Birth............

Distribution of Achlevement Ret1 os According

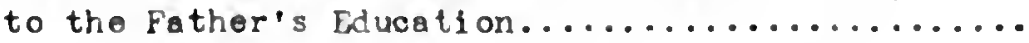

Distribution of Achi evemont Rutios Aocording

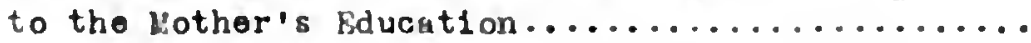

Diatribution of Achievement Ratios Aocording to the Sibling's Position in the faril $1 y$ I.......

Distribution of Achievement Ratios According to the sibling's Position in the faul ly II.......

Dictribution of Achi everont Rutios Aocording,

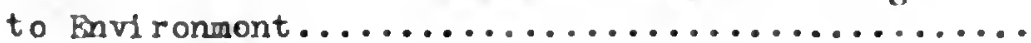





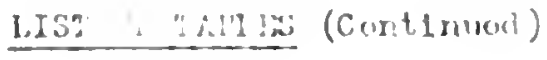

Table Nio.

Page

43

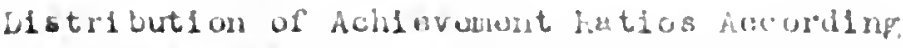

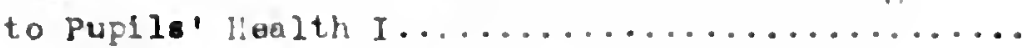

296

44

Distribution of Achleremont Potios Accorling

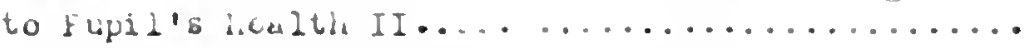

Distriution of Achi uveruent Retios Acrordinc,

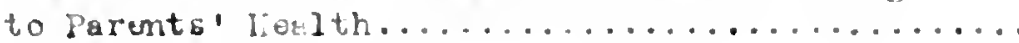

Distribution of Aohiovement Ratios According

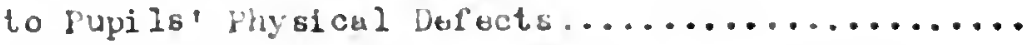

Distribution of Achlevement Katios Aocordin

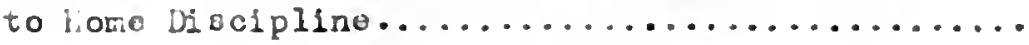

Distribution of Achievemont Futios herording

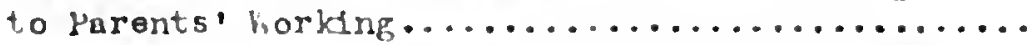

Distribution Showing the Relation of holidevecient

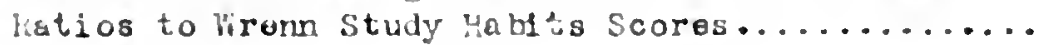




\section{LIST CI HIOURES}

E1rure No.

Pago

Achioventant hatios and Neshburne Truthfulneos

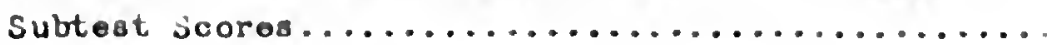

82

Achivesent Ratios and hashburne Happlnos

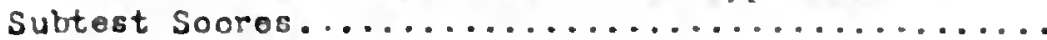

zohdeverent hatios and hashourne Allenation

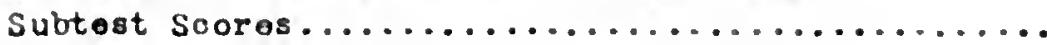

Achlevement Ratios and Washburne Sympathy

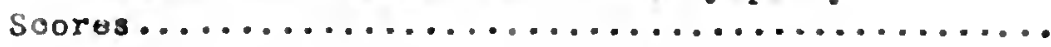

Aohlovemont Ratios and Viashburno Purpnso

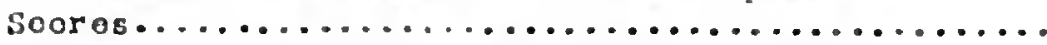

Aohiovement Ratios and hashburno Impulse

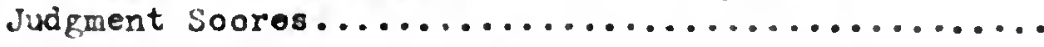

103

Achlevement Ratios and Rishburno Control Scoros....

108

Achioverent Ratios and Vashburne Totul Scores.....

113

Achloverent Ratios and Iink Invontory Socis I

Initiative scores.

Aohievement Ratiog and Iink Inventory Self

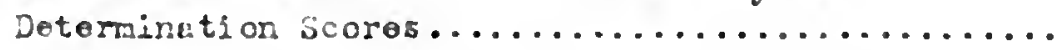

Achievenont Ratlos and Link Invontory biconoris

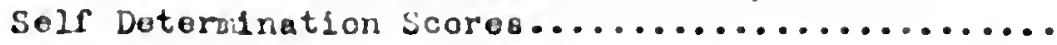

Achievement Rat1os and Link Inventory Adjustment

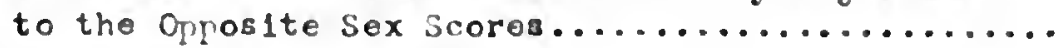

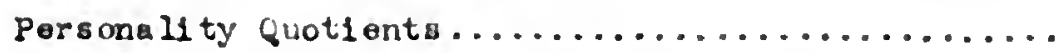

14 Aohs ovement Rat1 os and Sins Soc10-Eoonomio

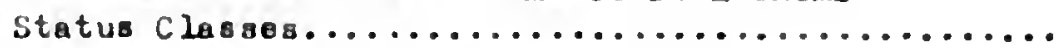

15 Achlovoment RHt1 os and Forelgn I.Anguacos

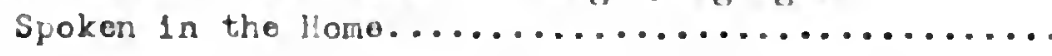

16 Achlevemont Ratios and Nivber of Amerioun

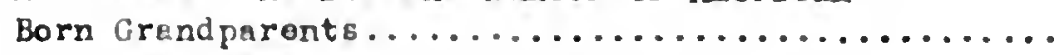

Achlovement Ratios and Fathers Country of B rth.... 



\section{LIST OF F'IGURLS}

Firuro No.

Pago

19

Aohlevament Rutios and Father's Fathera

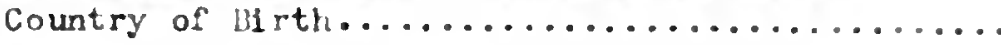

159

20

Achioverst setios and Fathar's Mother'a

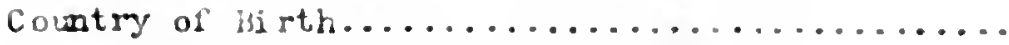

Aclioverient liatios and iother'e Fethor's

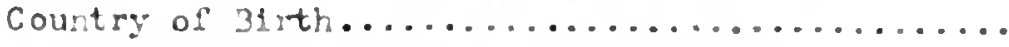

165

Achi evement Ratios and lothor's lothor's

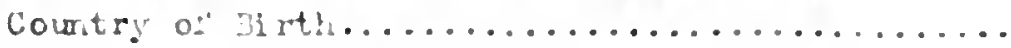

fchlevenurt kution and father's bducution.......

174

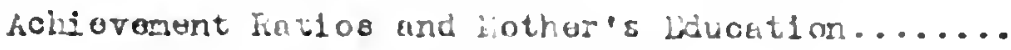

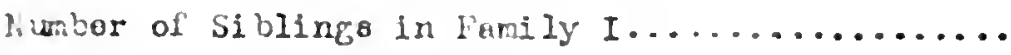

184

26

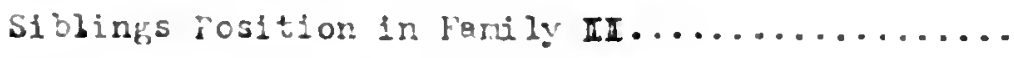

184

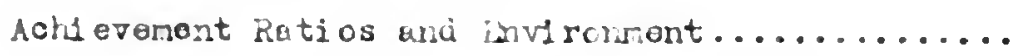

190

28

Aohiovement hatius and Pars ly Rosidenco..........

194

29

Achi ovenent Potioe and Puplis loglth I.........

196 A

30

Achiovement Ratios and I'uplls lloalth II

$156 \mathrm{~A}$

31

Achiovenont hatios and parunts health...........

204

32

icisovement Ratios and Fuplis Ihysioal Defects....

207

33

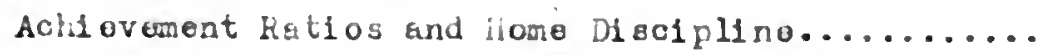

34

Achleveriunt Fetios and Iarents Torkine.......... 



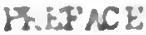

Why do intell1gent purila oftur fas 1 or do modioore rork? rihat are tho causes or faotors ssoolatod with the achl overant of superior pup1ls In soocondary sohools? his do one suporior puplis do good work in high sohools and others of oqual Intell1,once do pocr work? Ilicso, and other quostlons have chnllengod the author in his dealing,s with pup11s

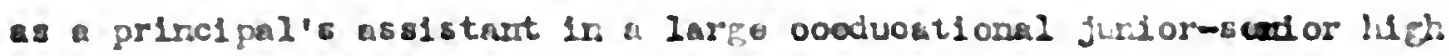
chool in Initinore.

It is not difficult to understarid why the mentally 8 low pupll eay hevo some diffloulty with the ourrloula of our h.1 hh sohools but it is another thing to oxplals why a hichly intoll1gent pupld w111 do bolowavarag work. Others whoso work w111 bo reviowed have wrestlod with the problow but it continues to daserve our conaldoration, for suporior pupllo are still warking far belos thoir oupeaitios in sohoole thoughout the world. A moro cocparioan of ang school's roll of hishly intellegent puplla with Ito ocholastlo honor roll would grovo thls polnt. Sohoolmen should more adoquately moot this problem of stimulating and asistinf. the suporior pup1l more closely to astch his intelligenoe with aollevecient and if thero is eny botter solution, seok it further unt 11 it 18 roumd.

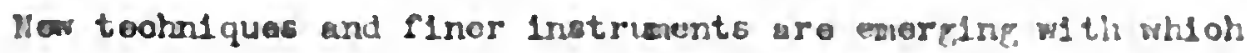
wo may wore offoctivoly study suoh isotors ws study hoble, plycloal health. soclal status, oocnoslo atatus, poraonsilty troits, acjustecat

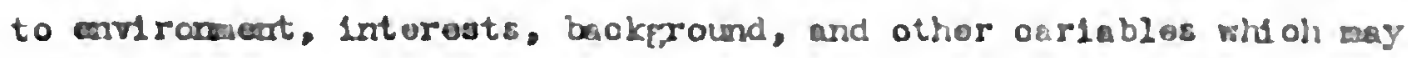
supply bottar answoro to our quections. Fith thoso aldo at hand to ut11120, tho author has folt tho urgo to Eonrch for the answer to this moblces. 

Tho problom is statod. "Mhat aro the factors assoclatod with the achlevamant of high school pup11s of suporior intolligonoo" Terme Deflnod:

High sahool pupils - In this otudy, high school pupils includo only whito pupile attonding grados nino to twolvo in tho Baltimora publio sahools.

or cupariar Intollifonos - puplls who havo an I. Q. of 120 or moro, as mosured by two forms of the otis Solf-Aduinistoring Tost of Kontal Ab1lity. Higher Eramination, and one form of the Hommon Neloon Test of Lental Ability. 
. 
CHLPTER I

PIEVIOUS STUDIES OT SUPERT OR PUPIIS TMO
DO HOT ACHISVE UP TO THELR CA?ACITISE

Introduotion

Idantifiontion of Giftod and Suparior Children

Individual Caseo

Studies of Groups - Rolation of Various Factors to Achiovenont

Anteoodents' Country of Birth

Foully Relationships

Forelgn Languagos Spaken in the Home

Hoalth

Hasso Disolplino

Parents' Eduation

Porsonglity and Aohiovement

Sibline Rolationships

Size of Pently

Socio-Economio Status

Study Habits

Sohool Provisions for Suporior Puplls

Sumary of Provious Studios

Tho Rolation of this study to Proviows Studies 



\section{PPEVIOU STUDISS OL SUPRIIOP. HU! ILS YHO \\ DO bOT ACHIITI: US "O THETE CAShCI:It:}

Introduot 100

iduators havo long adrittod that attertion and epocial help

should bo fiven fiftod ohildren. Su Pont do sumours sthted in 1 Evo in his "iational kluoation in tho United States":

A single day of an oduostad mon of genilus 18 of tworo valuo to tho worid than tho labor of 100,000 men for a yonr.

Tho late lete S. Holldneworthl has writtons

Eduostion 18 ohargou wth responsibility for tho dovelopent of ifted ohlidron. It is the prorosilamal duty of oducators to understand the froup wuch nore fully and proolsoly than they do yet.

On the other hand, many othors (Including oduot ors) have bolleved that bocause the superior ohild is ususlly ablo to do trerago vork, ho needs no speclel ald or attontion.

Only recently, howeror, has any bystocat lo otudy bour mado of tho suporior pupll. In tho 1920's, Termne and hs as Bletants rado an exhaustive study of Biftod ohlidren, tholr plysloal and montal tralts. The rindings Indiatod that tho noan of tho fiftod group was above that of unceloctod ohlidron in oducational aohlovoment, in health and plas lquo. In desirablo peroconalty tralto and in proportion of nas rulatives who had sade notable cantributione. In Vol. II of this aorles, Catherine 4 . Cox wado Hopraphical skotches of tho chlldhiod tralta of threo hundred outatandinf;

1 liollingrorth, lota S. "Clited and felontod chllaron". Journel of Eduartlanal Rosearoh, 6: 65, October, 1956 .

2 Fener. lewe L. and othere. Liental and liyslcal fralts of a Thousand

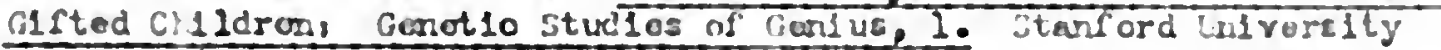
Prose. Callforna. 1925. 640 pp.

$3 \mathrm{Cox}, \mathrm{C}$. K. and ottore. The Larly Trolts of ghroe diundrod Gorluece:

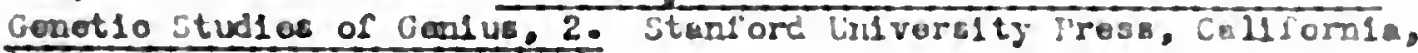
1026. 84. TP. 



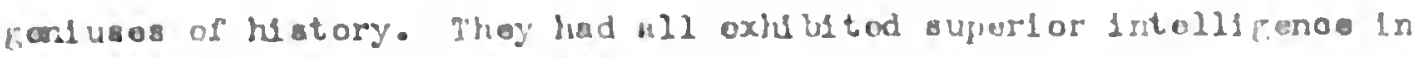

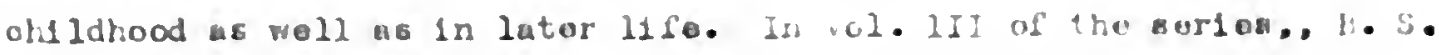

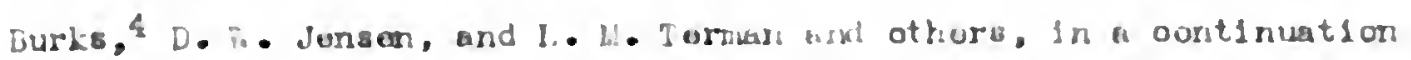

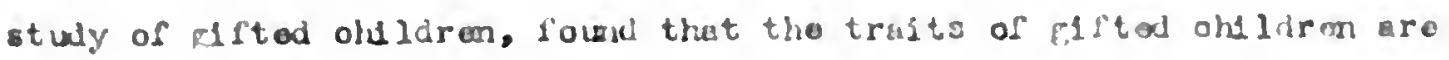
relatively permanent. Vhat wa true of the group studiod in 1s21-22 wos larfoly true of the same proup in 1927-28.

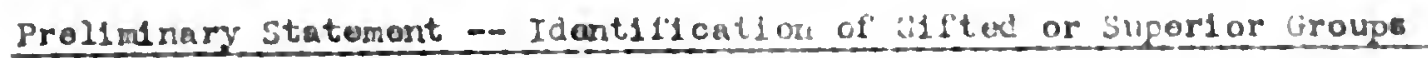
Tormen ${ }^{5}$ used un I. C. (Staniori-Uinot) of If() \& a a lower 11 mit for his flitod froup. llollingworth ${ }^{6}$ ued as hor oriterlon for puplla of superior Intoligence tho most latollifiont 2 per oont of the jurvenilo population. Her lower 1lnit, oaloulatod on tisls bals for auperior puplls, was an I. Q. of 130. Goddard ${ }^{7}$ usod $1 \% 0$ I. Q. ES lower linit in forming olasses for gifted ohildrem. Osburn und Fohan included those with - pocial talenta -- artítio and meohanioel, with no speoial linit an I.Q.,

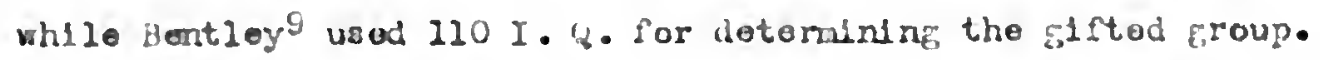
Fhen the Kovisod Stanford-B1not Scales 10 apyoarod 1n 1937, the authors olassed as suporior only those ohildron having. I. W.'s af at least 120 (the highost 12.0 per cont of an unsolected group), and as "very Euporior" only thoso with I. Q.'E of 140 or hicher (tho hishost 1 por oont, roughly)" 11

4 Purke. Bribara Stoddard and othors, The Prost se of Youth: Hollow up studios of a Thousand cifted chlidren, Gonotio studies ul Gunlus, 3 , Stancord linforsity Press, 1930. bou PI.

5 iaman, Jewle b. op.cit. p. 45

6 lollingworth. Lota 3 . Glftod Children: Ihelr Naturo and lourturo. Lnapilian Co. 1926, $374 \mathrm{pp}$.

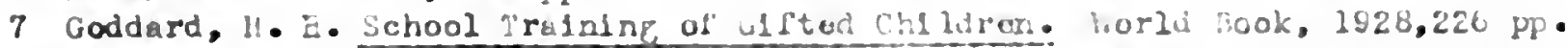

9 Cobrr, i. J., Rohan, Ben J.. Enrlchinf tho Curriculue s or ilited Childron, F. Y. Laoul 11an Co., 1931, $403 \mathrm{pl}$ •

9 Bentloy. John Fdward. Superlor Childron. P. P. . Fortan di Co. il.Y., 1437, 331 pp

10 Lerr111. Vaud $\Lambda$. "Tho SICnIfoance of I. S.' an the Rovisod stanford-Elnot Sor 10a." Journal of Mduoat1 onal Thyoholocy 29, 64. An anymous. "Charactorlotios of superior studonts"

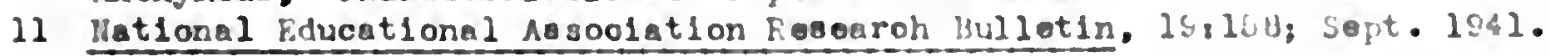





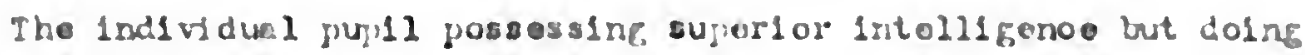
poor bohool mork has boon inveatigated by arliur reourch workoro.

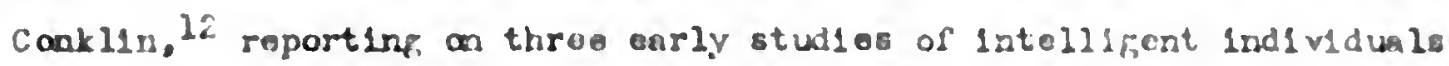
who Inllod, ando this obsorvation that in ouch Individual ondo, ollaical study has resultad in locatin, fuotors assoclutad with poor school adjotmant and in presorlbinf an offootivo remodial program. Othor Livastlfators are in genoral afrecuent with this rinding. Two typloal studios of Indlvidual veeos aro Includod to 11 ustrato this polnt. Irol11roworth13 prosents tho 0000 of child A. On tho adv100 of h18 school prinolapl, boosuso ho was a sohool problen. his paronts brought ism to the clinlo for nuatril tosts. Io wa not adjueting weil in tho sooand grade whore, at the ago of 6 yours, 6 vonths, ho had a stanford-inot

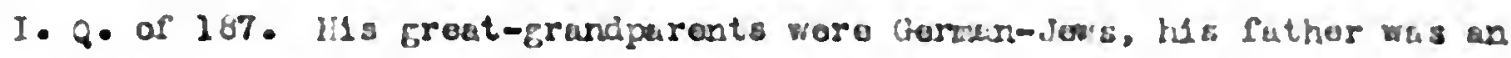
copinoor and arohitoct of ability with ar Army Alpha I. 8 . of 160. A's wother was graduatiod from lifh sohool. Buforo marrlago sho was an oxooutivo in oharge of advortislng, and at aro timo sho had care nawo nowspor work. Tho family in gonerul was notod for outstanding cold evo ments. A oould talk at 10 nonths; at 12 nonths ho oould say the alphabot forward; and at 16 oould sey tho alphabet bookwards. Iis loarnod to read duriar. his thled jour and proforrod truo storles of adventure. \& has always beon heolthys his adenoids and tonslle woro rocovod at 6 yeare of ap,o. ihylorl exarlnatlon roralod no defocts excopt wopla, for which. ho wore Eloases.

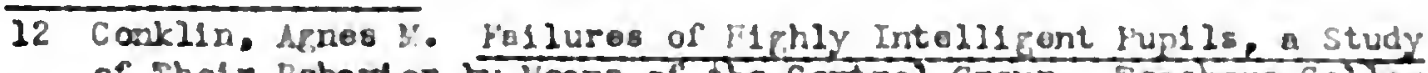
of Thair hehavior by leans of tho Cantrol Croup Toaohors Collog.

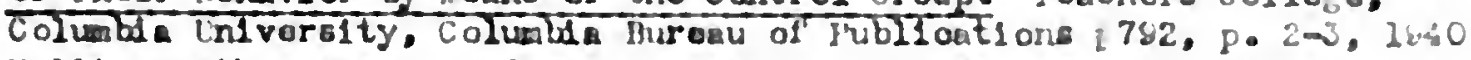

13 llollngorth, lota S. Glfted Clisldren. Ihels helure and liveture,

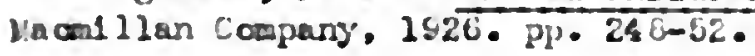




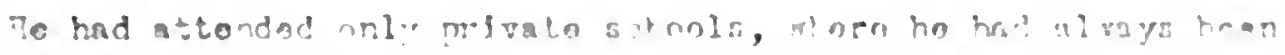
a prohlag to his touohars. Ho wat rot Intarozlud in achoul work ovg? 2 ar 3 gones bayunt the rore for his aro, and ho wat ton omell ard to yourf, to

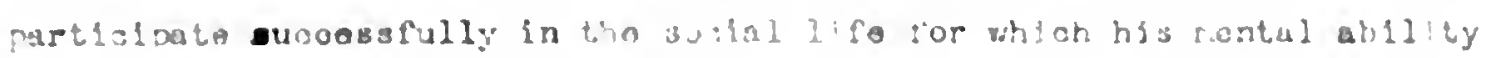
rlttos hir. Ho was ahsontzinde!, unlidy, slow to lato advico, but pood-

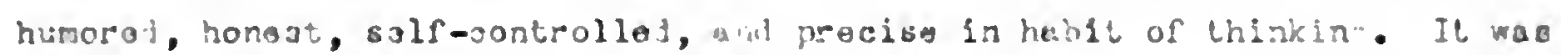
docluod to advanco $k$ ir. sahcol at a rube rapraiontinf a cospromiso between

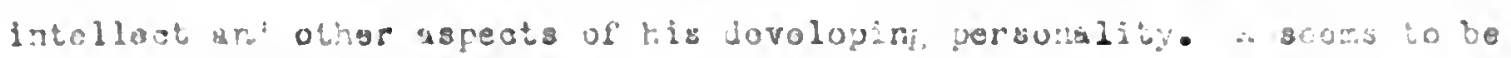
doip quito well undar this treatrent.

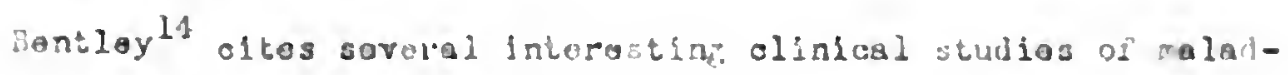

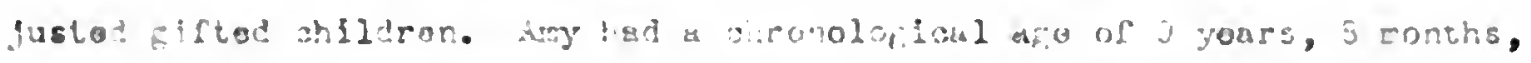

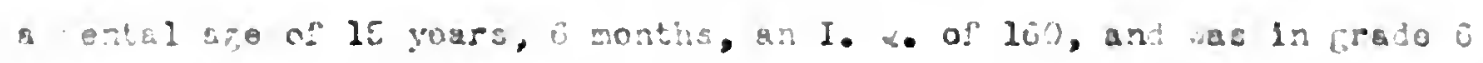
of tho iastingtor, U. i. schools. whe hat diffloulty from tho tirs sho was In the aursory school, and bocaro progrosively worro unt id sho roached tho eth erado. Tho prinolpal thon reocmorded hor reformal to tha ihild

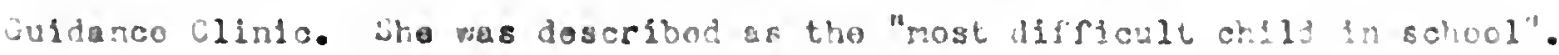
Ehe ras roportod to bo lmportinont, stubborn, and 1rrosporsil 1c. 1n class

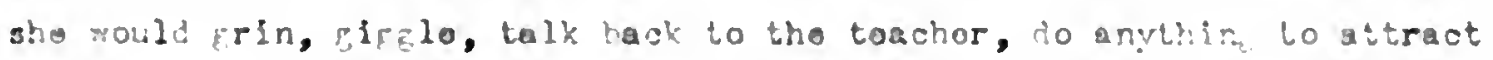

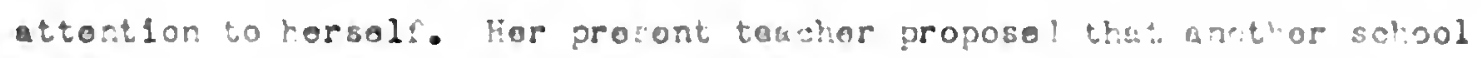

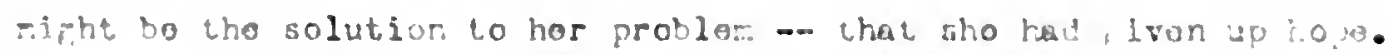

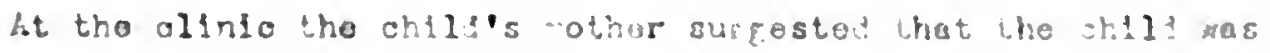

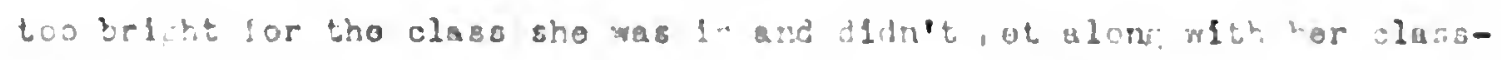

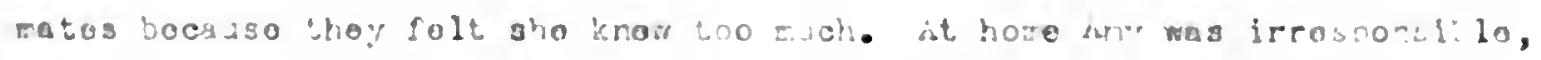

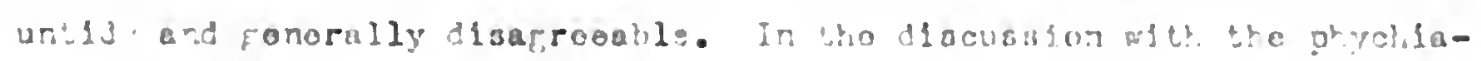

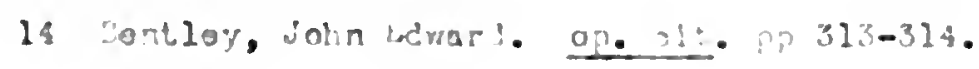



trist, Ary said that tho toachor was loo gtriot, and Eho fult that sho was unNantod by hor alassutes.

Psychologloal oxamination Indloatod that sho was 5 yoars acooleratod In mental ago and possessod a remarkablo romory. Amy vas accoloratod in school, but sho was still far ghove tho avorafo of hor prosont grado. On the clinio's reco-rendation, furthor school promotion was resorted to, which resultod in a dooided improvement in hor caso. Her school attitudo is quito satisfactory and sho cets aloni woll with her olassratos and toachers. Sho has no difficulty in kooping up with the school wark.

Both of these oases above illustrato hor clinical study has resulted in a satisfactory adjustment for maladjusted superior children whose performance was belor the pronjse offered by their intolligenco.

\section{STUDIES CF CROUPS}

Groups ô studonts possossine, hith intolligonco quotionts but failing or doinf, mediocre school work have been studloc, hut, resourch has not boen so suacessful in findin, the causes or proscrihine the romeig for types of maladjuctmont found. Tho difflculty lios in the fact that, wron doalin with proups, factors of hotorogenoity are introducod which. aro not present in "he study of an individual asse, althourh throukh the stidy of Eroups it is possiblo to obtain usoful gonorallzations yhlct may bo applied to similar eroups in tho future. vtudnnts in tho field of oducation have studlod this problam with varylnf docrees of throughnos and with confliotinf, coriclusions. Jany varlod oxplantions havo boen urrivod ut for the disorepanoy botwoen proniso and perfor anoe. 
A numbor of bolke Burgarlzite ruvearet on the ao' lovosont of auporior fropls hivo rocontly boun pul lishod. The mrllar's intention 13

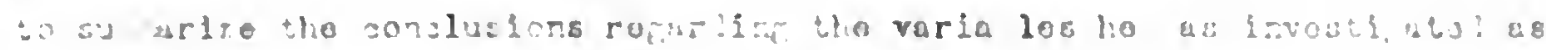

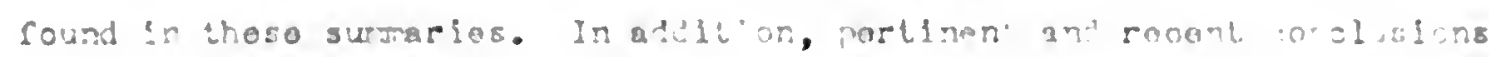

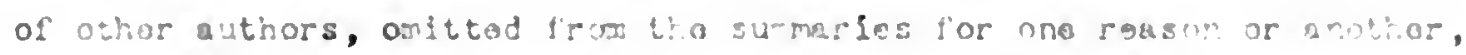

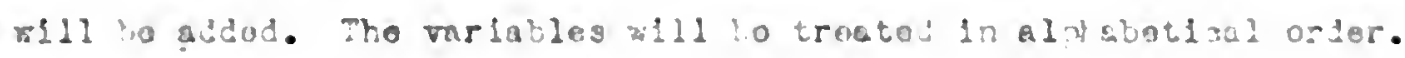
Artecojo:ts' vourtry of 3 irth

e. ant studios indiceta hat ho rastoranco of childror. o:

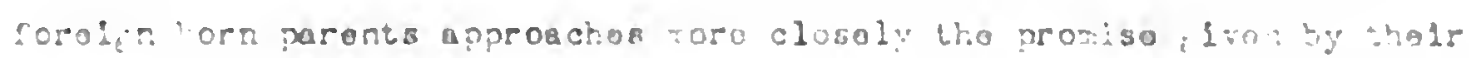

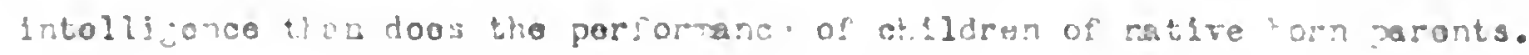

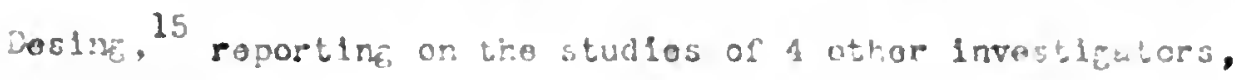

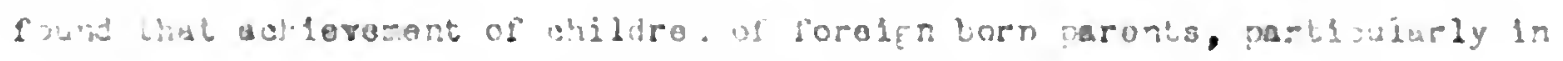

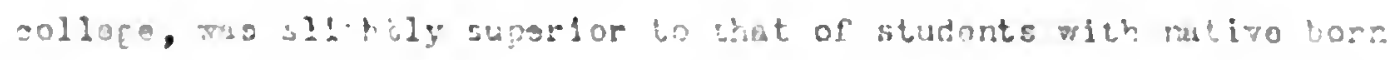

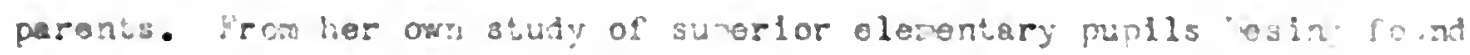

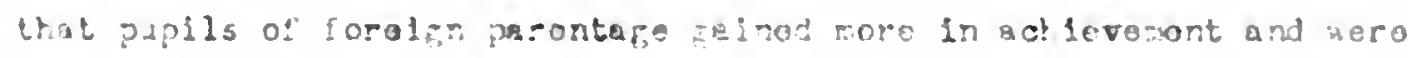

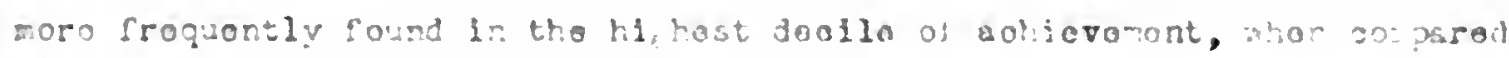
Ith pupls whose pareats wore h-erlonn torn.

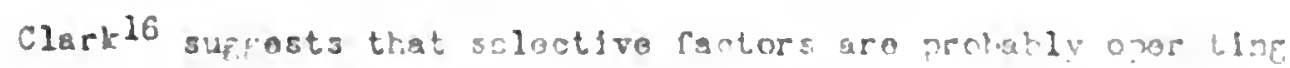

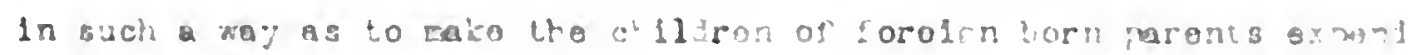

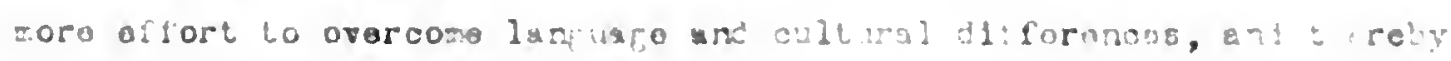
do gl thily bottor work.

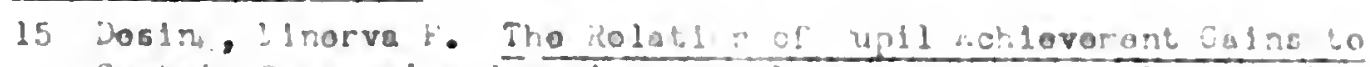

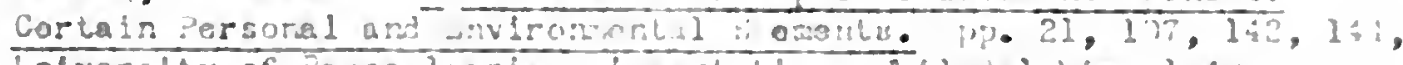

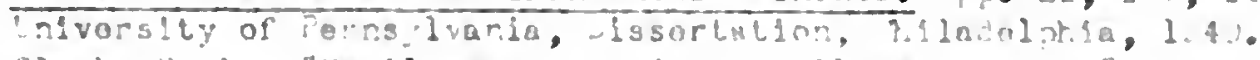

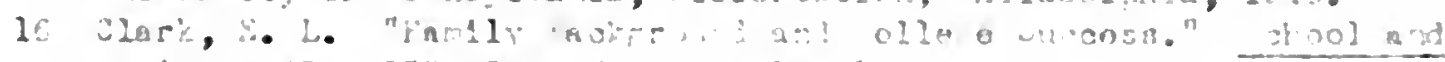

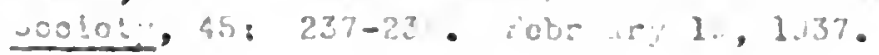



Strabel, ${ }^{\prime 7}$ In a otudy at tho Univorsity of Buffalo, found that a Ereator porcontago of suporior atudents havo forolga born paronts that do inforior studonts. Sho arreod with clark that this could bo aocountod for on tho basis that the pupils of forolen parentago wore probably moro hifhly motivatod.

Conklin, ${ }^{18}$ in comparing two Eroups of pupils of suporior intolliconco (ono froup charaoterized by fallures in secoadary sohool), conoluded that tho parents of both groups, almost 70 per cent of whom wore Imigrants, havo 11vod in Anorica for approximatoly tho sano lonfth of tino. The paternal grandparents of tho failing pupils havo rosidod In Amorica a 3ignificantly longer time than the patornal grandparonts of the sucoessful pup11s. Thero wis no real difforonco in the recency of imigration for the matornal grandparents.

Conklin's Pindings wro in disaproomont with most investigators. This may be accountod for by tho fact that such a high porcantage of her group woro pupilo of farelgn parentege. Possibly, pupils who 11 vo in a prodoninantly forelgn camsunity aro not so hichly motivatod to aohiove up to thoir capacitios as aro puplis who livo in a prodaninantly Anorican comminity.

17 Strabol, Eurtce. "Acadomic Success of Various Afo and Exporionce Groups". Studies in Artioulation of Hich School and Collogo. Univoraity of Ruf́ralo Studies Sor1es II, Julletin 3, Vol. XIII, 1936.

18 Conk11n, AGnos. op. c1t. p 113. 


\section{Fa-11y iolat $102 e^{2}: 20$}

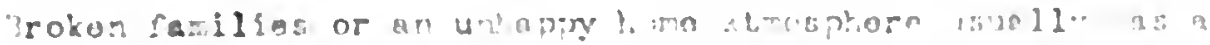

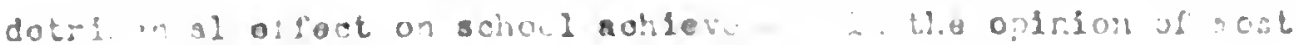

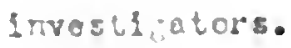

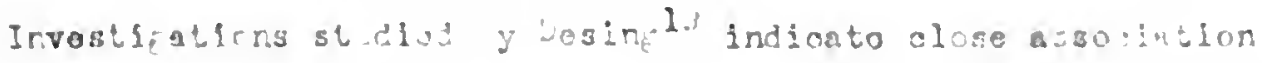

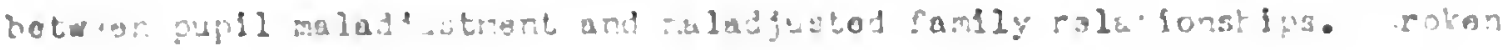

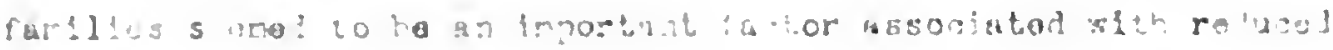
achlevarint of suporior puplis. Le for ant of those rala'jusle?

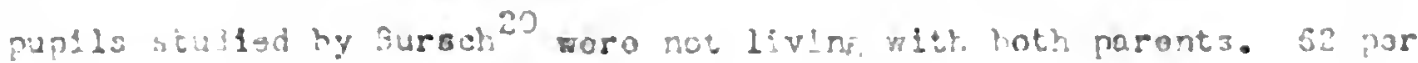
oent rore lisine with lholr actoen onl:"

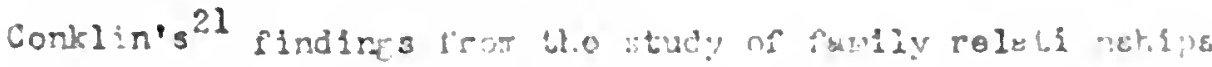
aro all unfaroretlo to the feili.2 cuporsor puplat. U1soipline onploved

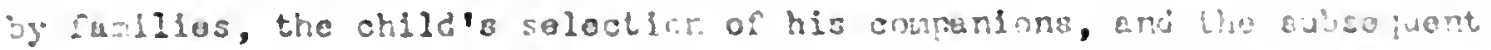

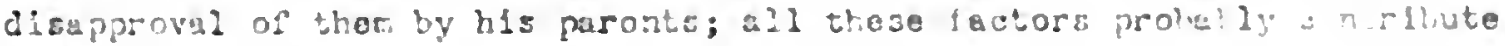
to U.c Elling status of suporior puplas in hlitb scheol. Conilin's diste elco isidcute trat:

Tro oomsratior of tho typleal charator w tho ra-12y, ranlly discisline, at the rolationship hotroen tho

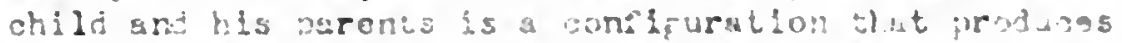
an enfavoretle offact upon tho exporinental proup. (fellin supericr pusili)

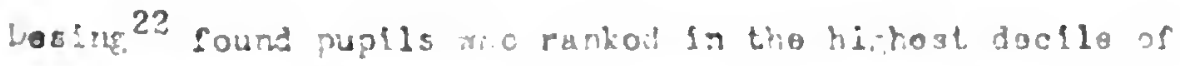

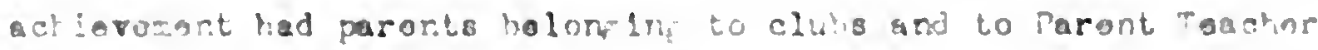
assuclaticns in larzor nutbors than perents of tho puplis in tha larost

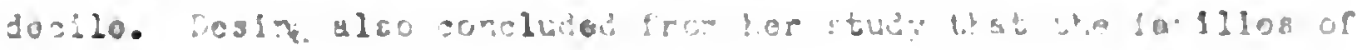

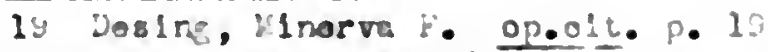

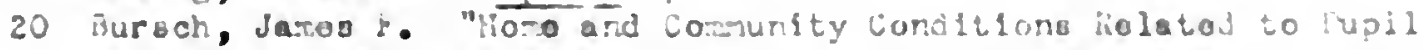
saladiustrent", Personality Adfustomnt of the lilarontar: S-h.ool

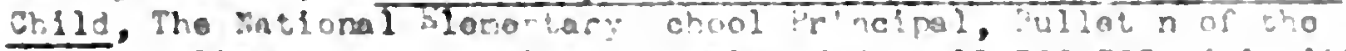

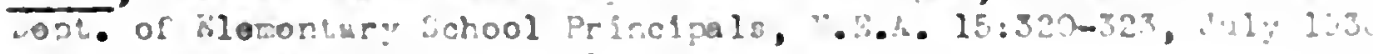

21 Conkin, hon on.e1t. p. 11 .

$22.0812,:\{$ rorva 

childron who wro problam oasoo woro largor, and sho obsarvod that tho problon cases usually ano moro froquently fran unnatural hasos. vosing si $^{20}$ otudy lod hor to tho oonclualon that ohildron of divorood paronts gainod 1880 in achiovamont than those from normal hones. Host of tho childron studiod by Dosing 24 woro sald to bo on olose riendly terms with their parents. A fow voro merely respoctful, Indicatiag a courtoous and disciplinod but formal rolation, wille a vory fow ware assignod othar atogorias.

The majority of the pupils in all groupe studied showod a gonaral lack of profaranoe for olthor parent over the othor. Usually wen preference was ohom, It wa for the mothor, enonf both boys and G1r1s.

Conkl1n 25 on the other hand, fonend that there vero no reliable differonoos botwoon sucoossful and failing puplis in the separation of parents, quarroling of paronts, and ganoral inhamontous relationships botwoen parants.

\section{Rogensburg 26 studier 50 casos of intelloctually ouporior} chlldren roforrod to the Buraqu of Chlldron's Guldance of liew York City. With particular acphasis on the faotors associated with sahool suocess or fallure. Lor findings indicato that,

iranted superior intellectual endorment, school sucoess is noro fully assured (I) if the chlld's oxporianoes at hans, while satisfylng, noverthelosa Induco his to faco weanlar; aporlonces froin an early ago in ordor to

23 Desing, Minerva F., op. o1t. p 107

24 Ib1d. p 121

25 Conklin, Apros. op. ait. p 120

26 Rogensburg, Jeanotto. Studios of Educatiomal Sucoosi and Falluro in Supornormal Childron. Arohivo of Payohology, 110. 129, p 13\%. Now York, lsay. 1931. 
Insure soolal Independemoos and (2) If he is enoouraged to be aotive, interestod in the world outside his, and ager to make oontaot with tho pooplo in it.

\section{Foreign Language Spoken in the Horno}

There 18 general disagreoment regarding the relationship between aohlevement and the use of a forelgn language in the pupil's home. Same investigatora find no relationship and othors Pind that a forelpa language spoken in the home offers no handlcap to the soholast10 aohserement of superior puplis.

In her study. Desing 27 found large numbers of puplls in whose homes a forelgn language was spoken in the group representing the highest 10 per cent in aoblevenent. She especially found that there wao a tendenoy toward a greater aohlevement gain amone children in whose homes a forelgn language was habitually spoken. Conklin28 again disagreed, ooncluding in the stuly of suooeseful superfor students as oompared to unsuooessful superior students, that forelgn languages were spoken in the homes of both groups to about the sams extent.

27 Nosing, Minerva F. op. o1t. p. 144.

28 Conklin, AFnes, op. olt. p. 113. 

Health and Physioal Traita.

There io littlo agreement, too, concerning the relationship botween ahlevement and hoalth, including physiaal traits. Thls appoars to be true whother intolligenoe is held constant or not.

The findings of several authors on the rolation of intelliconoe or mental developmont to hoalth and physios traits havo bean includod hero by way of introduotion.

Paterson 29 otatea in his Sumary and Conolualons that,

"Our detalled survay of avallable quantitative evidenoe has demonstrated that prevalent notions regarding the intimaoy of the relationshlp betwoen physioal tralts and intelleot have been grosaly exagerated. Searoh in the realm of groas anatony for a physical oorrelate of intellect has ylolded uniformly negative results. It appears that suah struotural oharacteristica as helght and welght aro correlated only slightly with intelligence, narrowly deflned."

Aocording to Paterson, 30 head size, skeletal developeent, dentition. physiologioal development measured in terms of pubosoenoe, indioes of body butld, and even physical defeots are found to bo relatively unrelated to mental developent.

The evidence seems quite cloar thet mental development prooeeds in relative independenoe of physionl condition oxoopt when disease prooesses or injuries directly attaok the central nervous systern, espocially the higher oenters. 31

29 Pateraon, Donald G., Phyalque and Intelleot; The Contury Co. Now York. 1930, 304 pp. p. 269

30 I Hd. p. 269

31 Ibd. $p \cdot 26 y-70$ 



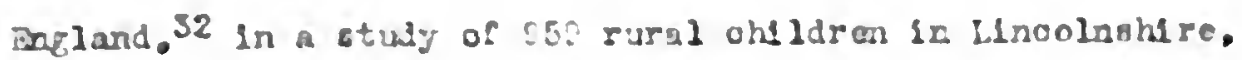
roportal no ralationship botween latoll gonoe and the total laoldanco of tonollar dlseaso. Iho:o was, hericyig, a largor porountago of tans1110otosles amang those of superlor 1ntolligonco. Thoso totnl Incldenoc 1 gires waro elular to thoso reported bs Teran for Aserican ollidren of hige I. Q.

Stout, 33 studylag pup120 tea yours 010. found that "the fact thut o ohlid is aormal in intolligonco givos I1ttlo or no clue to what hlo bealth or plysical ocalltion may bo."

joues 34 stutos in tho February 1939 Rovion of Eduosticnal Reaearoh that. "It 15 now woll eatablishod thet a 100 pasitive ourrelation, rapely hicher than .30. exlsts betroen the 1utol11gonce of childres and tholr physloal derclopacent as roprcoentied, for exanplo, in Eeasures of belght or wolght."

In the same sumerary Jones 35 sots dom several hypcthoses conoeraing the nature of this relaticaship.

"1. A cansea biolofloal factor or group of factors may favor ouperior devolopmeat of tio total organises absonec of thoso factors may have a geoserally handl capplng offeot."

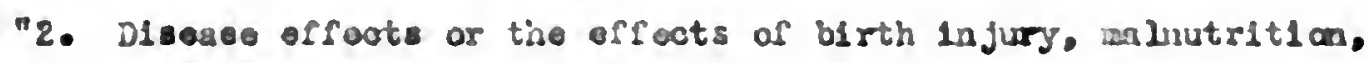
otc.. way be expresad both in the brain and in othor orgens with parallol d1sturbanoes in lator developront.

32 For thl referenoe see Jonos, Harold E., "Relationsh1pe in Physionl and Jantal Dovelogenout." Rovlew of Eduantional Rosearch 8.5\%. Fobruary 1030.

33 I lud. p. 97

34 Iमd. p. 135

35 I b4d. $\cdot 136$ 

"3. Say condition produolng an arrest or distortion in tho growth of intelligonoe or of the oontral integretive funotions may thoroby indirectly handioup the normal dovelopment of other funotions and othor struoturos."

"4. Soolal advantages or handloaps may almultaneously influenoe physical development (through nutrition and rogimen) and mental developront (through eduostian)."

"5. Physical-aental relationship may not be due primerily to a oorselation af superior or Inferlor statu. but to a oorrolation of rates of frowth, in this lattor oase. rolationships would be expocted to diminish in degree at the ond of the growth period." is Jones states, these hypotheses aro recelving considerable attention and their rolative importance will bo doternined by furthor investigation.

Lo on be soen from the introduotory paragraphs giren abore an the roiation of physical dovelopment to mental development, ollght agreesent exdsts. There is epparontly anly a small positive relation exloting between physioal dovelopent and mentel dovelopment as desoribed abovo.

The Enoyolopedia of Eduoational Researoh sumarizes with this pointed statenont:

At cone time physical unfitness wes commanly belloved to be aharaoteristlc of the intellocturily [iftod ohlld, but there is nos wuoh objeotive evidenoe to rofute this hypothes 18.36

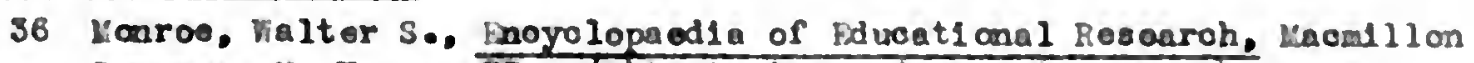
Compang. N. I.. p. 77. (Thi is taken from lloll1nkrorth, Lota., Glftod Chlldren, Tholr Nature and Burturo, Haomilon, 1926.) 
liv $\mathbf{1 1 2}$ noat take up tho rolatlas botwoch nuislercasat and health, inglwing physical tralto. Sovoral studise indicato that hoults or

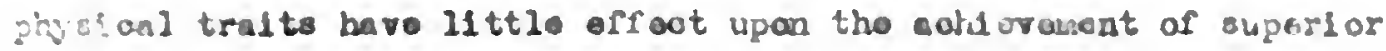
pifis.

Fickort and M111837 rind tho date on health ard health att.1tider alfferg Ifttlo betwoun two groupg of intolligent hith sohool suniurs. me group superior, and the other inferlor in ashervencent. Thoso Eroups wero, moroovor. rollably 31 fiareat in the nubor

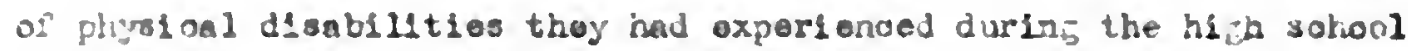
$p$ riod. Luterosting onough, tho wore auceroue ind sure sevare physlcal handloan hed been experloneod by the suporlor eretrol zroup of acinievize, pipilo.

D.. Coaklin38 ocmeluded, in hor stury of $100 \mathrm{kl}$ kh ochool ouplis of Inte1lgonce ranglnf, fran 130 to i6s. that throughout their llves lip to the high oohool porlod physloal hardioaps do not distinfulsh zlenlilantly botwoen puplia of suporior intellicenus who aro dolng gcod work in bleh sohool. and pupils of superlor intelligemoo who are dolne falling wark in high sohnol.

jones, 35 reporting on sororal etudius, said that Grogue found

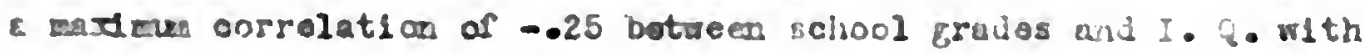
pinyioal 11tnese. Jones also reportal that strect, 38 in comparing wontaily suparior with vorage puplis in a vichlgars olenentary school, found no differenoe in physloal sitnoss.

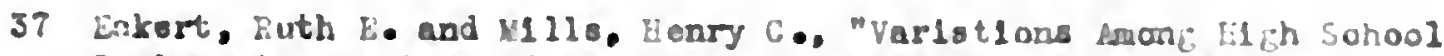
Senlors in Prandeo and Forforasano: L'ensuroe" School hovlcw, 44. 274-282. Apri1, 1936. 

Canolderable ovidonce hus boon found indloating that the opposito 18 true - that phyaloal fitnoss is assoolated with and oharacturlatio of the mentally auperior ohtld who lo dolng well in sohool.

Keal 40 feels that hoalth is the most important factor assoolated with ochool achlevenent. His rindingo indi onte that wherever physioal defeots are carrected, school schievenent loproves.

Invest1gat1ons summarized by Desing 41 indiagte that thore is a positive rolationship between health and sohool suo0es,. Six studies all indioate that various health faotors and physios dofoots are responsible in some mesure for inferior achievenont of aperior pup118.

Hollingworth 42 brings out the relationship between certain defects or talents to aohievement in particular fields. Nervous instablilty and word blindness may decreaso reading ablitiles of ono pup11, while the same pupil may be talented in other rielde.

Baker43 states that:

In geveral hoalth, in physique, and in ideals of sportsmanshlp, bright pupils appear to excol all other groups.

40 Koal. Honry L., "Kental Ratings, Soholarship, and Hoalth." School and Sooloty, 28, 277-280. September 1, 1928.

41 Dosing. LInerva F. op. olt. p. 17

42 Hollingworth, Leta S., Spoolal Talonts and Dereots, Laomillan Company. 1923. $216 \mathrm{pp}$.

43 Baker. Harry J.. Charaoteristio Differemoes in Bright and Dull Pup11s. Publio sohool Publishing Company, Bloomington. Illinols, 1927. p. 85 . 

Lowis, as reported by Janos, 44 found among grado reposters in North Carolina asitivo relationship botweon sohool fallures and possession of physios dofoots suoh unoorrocted visual dofecta, dofeotive tons1ls, and defeot1ve teoth, defective nutrition was less prodinent classification.

To sun up, oonsilerable agreenent extsto oonoerning the relation of physias dovelopuent to jental jevelopment. If any such relation exists it is probebly of small degreo.

On the other hand, when the relation of physical fitness to sohool sohlevement (without intelligenco hold constant) is concerned, there 1 s goneral disagreement. Somo investigators find no relationship and others find poor health and physical defoots assoolated with poor achioveriont oven with puplis of superior lntelifgonce.

Further researoh will evidently be necessary to cloar up many aspoots of the rolation of health and physical traits to acht evement.

44 Jones, barold B., op.c1t. p. 97. 

Bace D1solp1130

Fory 11ttle Invoctlgation has boen made of the relationship betwexs haso disolplino and the achlovasent of superior puplle. :he ovidenoe lalionter that puplis who are probleas in school aro nearly always probless at home.

DecingtE abservod in the study of 1250 onses that tho childran who wero problens at sohool woro also moro frequentiy punithod at rome. l'arants woro cunsiotent in indicating tho most requent typos of punfshwent to bo ioprivation, reprlinand and oorporal punlshont, in the order speoiflal.

\section{Parents: Eduost1 an}

inoro is considortilo disagreanent wong Investigotors regarding tise rolatiunsip betwoen the amount of parents elication and the achlovaneat of pupils. Littie of a conolusire nature has boen found ropardinf this vuriablo.

Ey nay of Illustration, five invostigations reportod by Desingts disagroe on tive effeot of parents' sducation upon achlevenont. Clarkit and $\sin ^{4} 48$ agroo that puplis vinose iathers have sare

\footnotetext{
46 Deslag. H1zarva E. op. o1t. py. 244, 121.

46 Desing, Mlnorva $F$ op. olt. F. 20

47 Clark. S. L. op. olt. p. 237.

48 Selti. llarry P- "Factore Related to Acacalo Achiovesent" (Abatract). Practicul Veluec oi iduestionsl lieceeruh. Aserlown kiduowtional Resaroh Asscolation joport, Gay lase. p. 27.
} 



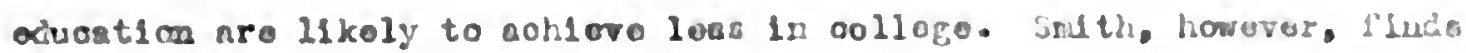
tho alucation of sothers positively related to acadendo oohl ovenent. Fill1amo on ${ }^{45}$ and Douglase and Carpbol2,50 on the other hand. find that pupl 10 who are dolng poor work in hleh sohool and college havo perents who have 1 ees sahoollaf than the arerago.

In her om study. Dealne 51 disooverod a ellehtly negative relation botsoon tho achlovenont galn and the fathor's oduoation, whil 10 there was a positive rolation botwean the achloversent gain of a pupll and hls mother's oducation.

\section{Personalfty and Aohloranent}

Thero are oonflicting recorts conoerning the rolation of perscrality with porformanoe up to proetse in ochool. Good soclal adjuctucent appears to bo assooiatod with high iutolligenoo. The relatian of aoblescant in school to personality tralto or social adjuotraent 18 In question, and oven raore unoertaln is tho assoof ation botwou porsomilty and how olosely echievoment approaches tho frowl se of 1ntolliganos. Stazner62 aays, "Linoar oorralations of 1ntoll1gonco, candereacent and personallty mosuros aro $1 \mathrm{~m}$ and aro probably so as a result of tho Inherent naturo of tho relationship." Tho gelation to be studied my bo divided lato throe partss the relation betwoen persomality and intellifoncos personallty and schlerenent, and perscanlity and achioring up to proxlso (Intell1 fence hold high and onnstant).

4. Filliameon, E.G., "Tho Slgnifieanee for Eduontianal Guldanoe of Porsonal Ilistorl os." Sohool Rovlow, 44: 4, 49. Mrwary, 1936

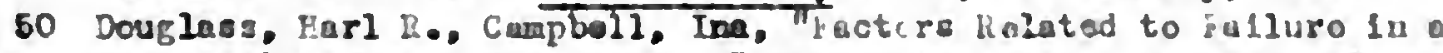
UInncapolis Junl or Ill gh Sohool," El Gmontery Sohool Journal, 37. 186-185. Hoventor, 1936.

51 Desing. Linerva $E$ op. olt. p. 107.

52 Stagner, fios. "Tho Kolation of fornowall ty to hoadealo Aptilude and hohlerescent." Journal of kuluchtlonal hescaroh, 20, 646-600 Lay, 1933. 

The rolation botwoon porsonelity and intalligenco w11l be takon up first by way of introduotion.

Tho Natianal Education Assooiation Rosoaroh Bullatin 53 roports on the social, anotional, and moral treits of montelly suporior ohildron. Thoy tond naturnlly to associnto with othors of sinilar nontal ngo rather then thoso of similar ohronolofical age and aro chosen as lcadoro moro oftan than avorago childron. Thoy bohavo wall in rroup activitioa, but spend more tino in individual activitios. Thoy aro less inclinod to nervous disardors and concrelly, whon social maladjustment occurs, tho causo should bo sought in tho child's homo and sohool orrvtronmont as woll as in his physical condition.

There is considorablo ovidonco to indicato that euporior intell1fonco 18 positively associated with suporics porsonality adjustment. Acoordine to Iorroej4 meseerch on fiftod childron has show good social adjustmont to be asgocieted pith hiph intolligonce". ollingworth 55 found that gifted children ratod as woll as unseloctod ahildren 1s onotlons stability and that there aro feror ncurotics amon them than anon; other proups.

Lost authoritios tako the position that the porsonelity of a givon individual is tho resultant of an intoraction botwoen conotic and onvironmental factors. . ilost thoorios of porconality disturbance aro basod spon a trmarting or frustration of drivos. Froud strossos tlo 'timatias of ploacurablo sensations of tho body', Adlor strossob 'conflict betwoon individual otriving and cooial mores". . Sanotinos tho conflict is due to plysical linitation, somotinos to the social sottinf. 56

55 Ancremous, "Charactoriatica of Supor 1or Studonts", lationa Education Association Rosoarch Bullotin. Vol. XIX, Tio.4, p.160 Soptonber, Iख⿰氵

54 Lonroo, Naltor S. op. c1t. p.77

55 Hollingworth, Lota S. Glitod linldron: Thoir iaturo and urture, lacalilar Co. 1926, $374 \mathrm{pp}$.

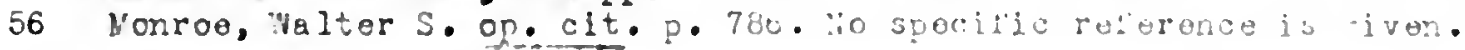



Dosing 57 found in hor study that the groat majority of problan cosos woro in tho lon intelifgonce proup and that thoro waro noro boyo than firls. Tharo is considarable ovidonco, howrovor, that, with or whout school ouocoss. pupilo of ouperior Intolifgonce are found arang madajustod croups. Conklin 58 notes that in hor study thero are 4 tinos es many maladjustod pupils anome her 100 casoo of suparios studonte than would be axpocted in normal sohool population.

Payne and Porry 9 cans to the conclusion that "sorno of those students who make hiph (I.Q.) scorea havo anotional difficulties, porsonality maladjustrouts - - and are satisiod with tho 'fontleman's nerk of C'".

Tho Clinio for tho Soclal Adiustmont of the Gifted of the Sohool of Education, Hew York University, as described by Zorbaugh and Boardman, 60 mentions a numbar of spocifio maladjutmonts of Eiftod childron

-omaresis, masturbation, stuttorine, hysteria, campulsions, mild obscession, seclusiveness, excessivo day dreaming and phantasy, torpor tantrux, quarroling, flehting, dafianco. ruming arry from howo, truancy. lyine, stokline, ouscono talk and valting obscone noter, seor dolinquency, and tho 1ike. In all of theso children, howevor, the bohavi or which lod to tho ohild's rofarral was cloarly symptamentio of an undarlyine asotional disturbanco.

It sooms rothor woll ostablishor that puplis of suporiar Intelligonco are moro likoly to havo well adjuctod porsonalitios tivan thoir less intelligont brothor s. Suporior childron do, howovor, guito

हT Dosing. Minorve F., op. c1t. p. 144

68 Conklin, Apnos, op. cit. p. 6

59 Paymo, Srthur 1. and Porry, James D. "The Intoll1gonoo Randinf of 250 City Collogo Fonor Studonts," School and Soclety 42 : 385-3 44. Soptembar, 1935.

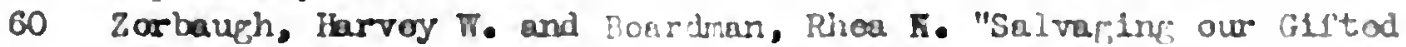
Children". Journal of Educetlomi soclology, 10: 100-108, Dotobor, 1938 . 
. 
reviuenty develop perconulity maladjustmonts which are lib o those of any other typo of pupil.

Wo shall noxt take up the relation of personnlity to

aohievement.

Stagner6l in his review of 45 invostlgutlons, roported almost uniformly low, zero, or slightly nogative correlations botwoen fayorable peroonality qualities and school achievement. Pintner62 in his survey of invostigations found tho samo thing. There is littlo agreancut anong the investigatore reported by conkline3 as to the relatianship botween personality and the achieverant of superior pupils.

Rothnoy 64 rinds little rolationship existing botween most perconalit: traits and coadond collego scholarship aocording to sevoral studi es reported.

Stroud, 65 in sumbarleinf soveral studios on porsonallty. oompared superior pupils (I.Q. 120-148) to inferior pupils (I.Q. 50-79) In social adjustment. "Infantilism and regressivo emotianal and social betavior were more frequent amang the superior; disturbing behavior at home, maladjustmant at sohool und Intersibling oonfliots, anong the inferior."

61 Stagner, Kose. "The Relation of Personality to Acadencis Aptitudo and Aohievement". Journal of Eduostional Reserroh. 26, 648-CiO liay, 1933

62 Pintrer. Rudolph. "Intolligenco Tosts". Phyohologioal Bullotin, 23. 163-472, July. 1935 .

63 Conklin. Agnes. op o1t. p. 3-6.

64 lothney. J.F. and Roena, B.A.. "Appliculiops of Yersonkllty and

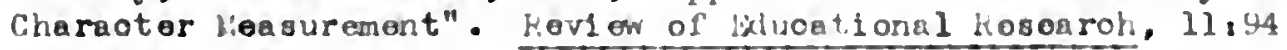
Yabruery. 1941.

65 Stroud. J. B. "Phycholopioul Teats and thuir Uoes". Ruvi ow of Bduostional Research. 11,29, Hobrunry 1941. 
i j 
Inveatigators including Gohan, 60 Stoore, 67 Finch and honcok, 68 Francl $c$ and 11 more. 09 Turnoy, 70 p c: fenberger and Carpenter, 71 peynter and Elanohard 72 and Siagnor 73 found that corrolations botwoen uohlovocont and various personality traita rango frau 0 to . 84 . Neaing ${ }^{74}$ roported that the majority of these investigators found positive relationshipe of varying degreo botwoon achiovement and such traita as anbitian. stoblity. inliative, porsistenoe, trustworthiness, sonse of acauracy. perseveranoe. Industry. leadership. care for dotall, motor inhlbition.

66 Gohnan. A. L., "Factors other than Intellifence Portaining to Sohool

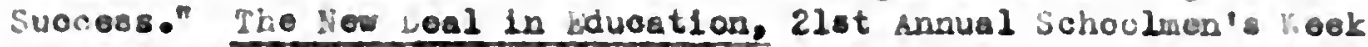

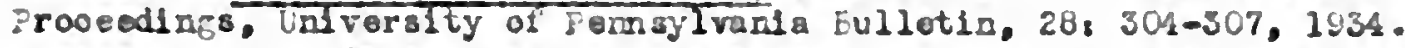

67 Steore. i. J.. "The Effoot of Craractor iralts on scholastic Achiovemeat." school and Society. 29, 707-708. June 1, 1520.

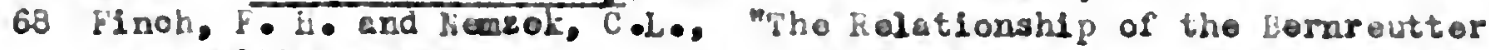
l'orsonality Inventory to Scholastio Achievenest and Intelizenoo." School and 5ociety. 36, 554-556. Noverber 5, 1532.

69 Franois, Konnoth F. and F1lnore, Bva h. The Influenco of Fnvironent upon the forsonality of children. Inivereity of Iowe Studios in Child helfaro, vol. 9, no. 2. ¿'ay 1, 15.34, p. 44.

70 Iurney, Austin Fenry. "Intollizenoe, Lotivation, and Achi evorent."

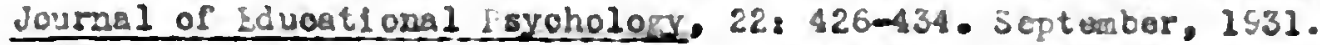

71 Foffeabercor. A. I. and Carpanter. Florovoo L. "Charactor Traits in School Success." Journel of Exporimental I'sychology * 6: 67-74 fobruary. 1924.

72 Jaynter, Kichard Eeary and Elanohard. Phyl116. Eduational Aariavenent of rroblew Childron. Sew York Comomealth Fund 1529. P. 41.

73 Stagner. Bozs. Tho bolation of Porsonallty to sosdonio Aptitudo and Achieverent." Journal of Educational fosecuruh, EG: S48-600. Kay. 1933.

74 Dosing. Hinerva F. op. o1t. p. 16. 

Dosing 75 notod in her ow study that although hor problom casos ranked lowest in intelligenoo. thoy rankod botwoon tho uppor and lowar docilos in achiovomont.

Opinion is apparently dividod on the rolation botwoon porsonality and achievemont. Tho conounous of oplinton appoars to bo that of any rolationohip oxisto it must bo rathor mall.

Wo shall noxt consider a special aspoct of the rolation botwoon personality and achievamant - i.e., tho rolation of persanality to tho disparity botwoen ability and achiovomant. As Starrak says, the falluro to worl consistently up to ono'o capacity is demoralizing to chrrater or pers nality, bosidos boing a groat sourco of waste of hum enoriy.

The Iora stato College has dovolopod a corprohonisive procran for elininating this onornous vasto of onorgy causod by poor aohiovomont of superior pupils. An important part of tho progran concorns porsonality defocts.

If personality dafocts aro found to be one of tho chiof causos of a studont's verking below ability, as is Fonorally bollovod, wo should encourage tho devolopmont of a systamtio program in porsomal dovolopront. 77

This would Lrvolvo sovoral activitios in addition to instruction in personality lraprovmont. Battar study conditions aro providod, tho numbor of sancstor hours of rork is roluoad, participation 75 Dosinc, Linorva $\mathrm{F} \cdot$, op. oft. p. 141

76 Starrak. J.A. "Latching $\Lambda$ bility wh Achlovomant". Journal of Hichar Education, 8, 315-320, p. 315, Juno, 1337. IbId. p. 315 
in axtre-ourrioular aotivitios is restricted, timo spont on out of oollogo work is roduoed, and oooporetinn of parents 1 s anllstod as parts of the propram to etimulate students workag bolow their apperent ablities.

\begin{abstract}
Enowh difforenoes havo boon disoovered, however, to warrant the poneralletion that a moro soourate undorstand 1 p of tho Individusl student w1ll be uttained when the pattern of his performanoe 18 considered us woll as the gonerul lovol at which he aohi over.78
\end{abstract}

According to Wrenn. 79 if we should "step up" tho mindmur levol (of ochlevement) for th16 group (of above average intelligenco) to a polnt where $1 t$ was at leat somexhore near their potantial lurel of achlevenent, wo should flad a largo proportion of them sadly malsdjusted, scholastioally and from the point of view of an integrated porsonality.

Personality defocto in general and certain defects in perticular have boen blamed for causing the disparity between ablity and achievement. Iraxler 80 writes in the ftrruary 1941 Reviow of Bduoational Researchs

"It is rocogaleed that wany instanoes of disparity botweon ablilty and achievanont are explained by variation in a oomplex of personality factors covered by tho tora persistenoe."

Ryans 81 adds to the confusion when he reports lar oorrelations botwoen perolatenoe measures and Bernreutter Personality Iost scoros. Ihls must not be takon to mesn that there is littlo rolation botwoon porsonality and

78 Eckert, Ruth E. and 21118, Heary C. "Patterns of High School Ierformanoo," Studios in Artioulation of Hiph School and Collero. Series II, Eulletinf4, Ualvorsty of Buffelo studios, Vol. 13, 1936. p. 180.

79 Trenn. Charlos Gilbort. "Aldinf the Flt." Joural of Hi hor Education. $6,357-363$, Detbber, 1935.

80 Traxlor. A. E. "Current Canstruotion and isvaluation of For aonallty and Charaotor Iosta". Rovlow of kducatlonal 108enroh, 11,11. Fob. 1941.

81 Ryons. D. G. "A Tontativo Statent of tho kolution of rerelstonoo Iost Scoros to Cortaln Porsonality Traits as soosurod by the bernareuttor Inventory." Podagogloal Seulnary and Jourmal of cicnoral reychology. 64. 225-34. Haroh, 1959. 



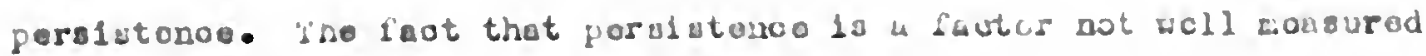
by porsonality tooto nay aocount for a grest part of tho discropancy Letweon ability and aohievement.

Stapner 82 way have tho answar won ho statos thats

"LiEh axotionalit; and tifh solf-sufflelency load to low or cohievenent than would be predicted from intelligman scores."

As yct thero appours to be considerablo dingroesent abnut the relation botween fersonality and the lowor than expooted nahteruicht of auperior pupils.

\section{1 bisig Rolutionships}

Littio ouclusivo ovldenoo has been fourd cancerning tho relation of tino birth rani of albling to tho disorupanoy between proulse and periorince for puplis of supcrior intallifence.

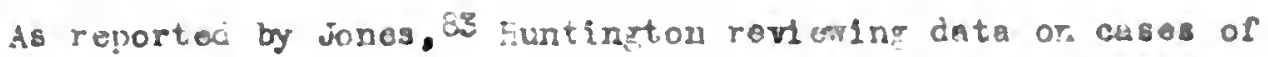
outstanding ochlevemsnt rejorted by Cattell and Lavelock 1.111s, corcluded that the advastage of the firat-born lises primarily in bottar halth.

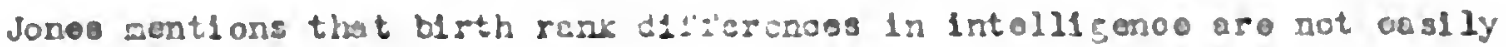
denonstratal. Conk $110^{\prime} 84$ f125\&nes rero not in aprement wlth liuntington on this polnt. Nolther her successful atudente nor her falline superior pupl is show arry predominance oi favoralle pooltion for tho ohlid aron his slblinge.

Undeslrable rolotions botwoon a pull and his slbliaps or ha parente appoor not to differentiale botwoen succosiful and gillin: superi or pup1la.

82 Stapner. Roas- op.c1t. p. 659.

Q3 Jonee, Eorold E. ece elt. P. 100-101.

84 Conklin, Arnos. op. c1t. HP. $119-120$. 

conk11n,85 In her stud; as of bl1ne relationshlpo botweon two Eroupe of fullige and ougoessful hth soliool studonts of suporior Intoll1funoo, fouml that undesirablo rolations betwoen a pupll and his sibliars. suoh a compotition, quarrallne, and domination, aro not espacially oharaoterlstic of olthor froup. Conlila also found thut the

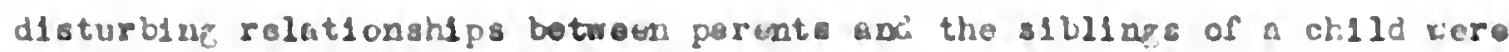
round to coour to an equal extent in both groups. Rotroen a third and a fourth of the chlldron studiad by wesing 86 wore sald to ect aloni better with pleyratos than with their s161100\%

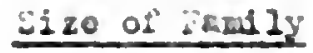

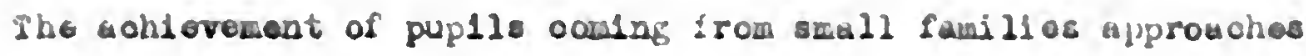
wore olosely tho level thelr intell1 gares leavis us to expect of tisen then does the ahlovement of pupl ls coming from large fasilios. I0 stato it nnothor way. the smaller the pupll's facily, the noro $11 \mathrm{koly}$

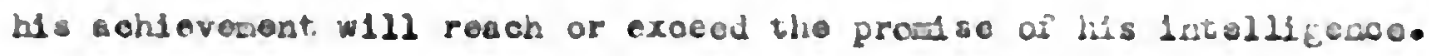
J. L. Stroud. 37 sumarizing is ve ruoent studlos, says that test Intolligonco lo negativoly corrolatod wi hu birth ratu. ihts way be considered re ladiroot oridonce that birth rate cr size of forlly 18 Degatively rolitod to aolitercent. 1.e. the weallor the fenlly tho bottur the sohd erenest.

irifithe 88 and Eurach, 89 as reportad by Dosini,80 flnd a

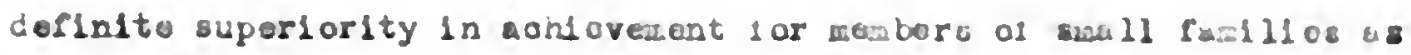

86 IUd. $2 \cdot 120$.

86 Dosing, Klnerva F. op. clt.p. 121

87 stroud. J. H. "Paychologioul Iests and thal usos." liover of

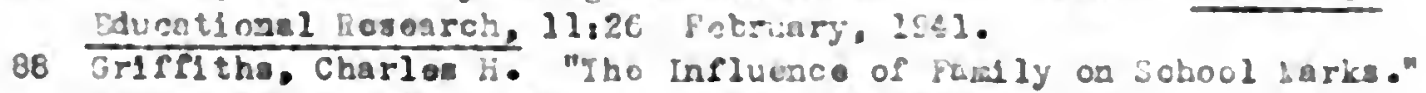
5chool and Soglety, 24, 713-716. Doocibor 4, 1920.

89 Bursch. James F. op. o1t. p. 320.

20 Dosing. "inerva i. 0.01t. . 2ij,21. 
o omparad with matbers of Large fanllies. Desing 91 disoovored that there mas a positive relationshlp between the alze of fandly and maladjustrast in the school.

\section{0-Econocic Status}

For positive results have boon found rozarding the rolationship of soolomoconorlo status and achlerenent of superior pup113. Seroral investlgatlons 11 stod bolow aro in oosontlal agrecunt on this point.

Sigt studies roportod on by Doslag 92 show inoonolusivo results regurding the relationship betweon soclo-oononio status and sohsevesent of Intell1gent pup11B. Corrolations rango frari .02 to .40 .

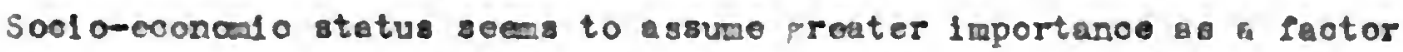
affooting achievenent whore maladjusted children ere ooncornod.

There is 11ttle difference botween the tone settln of

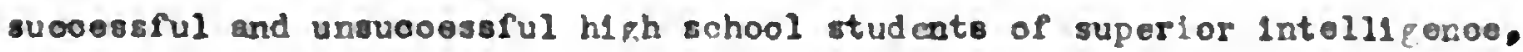
according to Conklin.93

Eokert end $31118^{94}$ IInd 11 tt lo difforenoe betwoen the data on hose bakground for ouocossful and unsuoceseful hl ch sohool scalors of suparlor intelligenoo. Doolnz.06 in her study of 1150 oleseatary puplla of avorago Inte111gence, conoludod that "a tonjenoy was noted for houling adequaoy to be nogetirely rolated to achlovenont galn." She noted that ohlldron of faullies recelving so forn of IInanolel ald gainod less in aritheotio and English, although her otudy Indlat ad

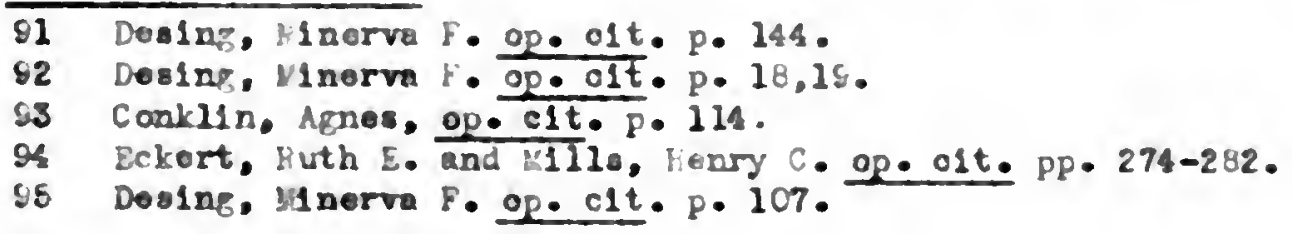




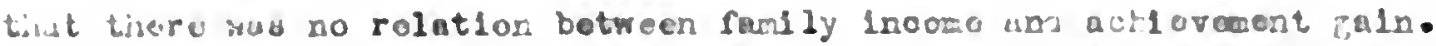

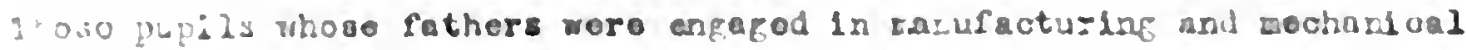

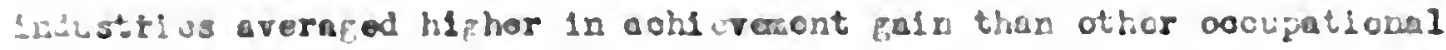
broups. Lor study al6o lod to the conolusion that puplis from homes in

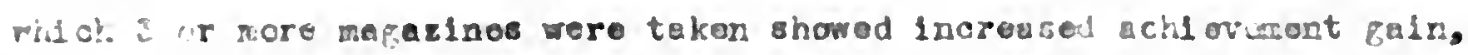
slthouph thit number of books or sewspapers evallublo anflirent. Iy ghowod IC sich relation.

in 1111 ans 96 emphasizes a point proviourly refersus to by

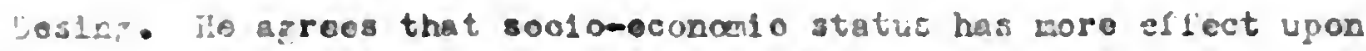
with ovent where raladj atmont 16 also present. illilaw statos that "Btuiles ocntinue to exphanize the relationship oi hous und oomghrity conditions fo soolal calajistment in ohlldren. and thsso are ofton of 1.:-eninto concern to the school."

Investigatora are In goporal a recrent thut ihorc supertos pupile are involved, the relation between sucio-econorio status and whicrecent is positive but low.

\section{Study Eabits}

3lost investigators agreo that there is a posicive rolation botwoen study habits and the cohleverent of suporior fuplis. There is

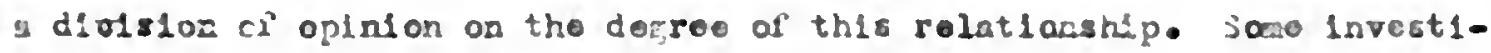
Gutorg tolleve the assrofation to bo very olase bus othare find that the pooltivo assoolation botwoen otudy habls and achloveront 10 soall.

06 nillient, J. Larold. "Tho soolally laladjusted." Revlow of Bduoat1 cemal Researoh, 1250, Juno, 1541. 

Eckert and Mil1s 97 roport that tho difforoncos in studiousnos

botrood suocessngl and uncucooserul hich sohool soulors of suparlor intollifance aro rathor great, and ads that intollifonoo apparantly plays but a ninor rolo in the dyrames of study. irann 98 concludad that studuils whth high Thorndiloo (Intelligonoo) scaros but in the lovor 20 por cont for soholarchip ahowod tho following charaotoristios to a significantly groutar docroo then did the hich soholarshlp group:

1. Thoy miss importart points in a lecturo willo copying down notes on provious material.

2. Thoy rad so slorly thoy cannot got over all assigned material.

3. They aro loss caroful in noting main and paragraph headings and surmarios.

4. They do less ovorloarning boyond tho point of innodiato roce 12.

5. Thej are lose apt to got each point as tiroy go over it, but tond to com beok.

6. Thoy aro inclinod to tako sono tino to got settlad and warned up, to rait for 'tho mood to striko them', and to find it hard to vork undar prossuro.

Aocording to Conking? in hor otudy:

Tho omo psychological findine is that tho coporinontal (superior folline) Eroup compares unfavarably with tho control (superior suocossful) irlth ruspoct to tho studiousness indox. - It 18 moro in tho matruro of a lindiag to discorcr that tho girls of tho exporimantal rroup, not tho boys, lack interest in thoso dosires and aotivitios known to claractorizo studious pooplo.

Throo invastigators, a s roportod by Dusing, 100 cano to tho conclusion that oldor pupils spont moro timo in study than jounges. Girle opont rore tino than bogs, tha avarafo fo hich solnool pupile

97 Eokert, kuth b. and Lills, Houry C. "Vaulations Arom, Heh Sohocl Sontars in Praniso and Por formanoo llorsuros." School Roviom, 14: 280-31, Aps'11, 1936.

93 Tronn. C. Glibort. "Aldis; tho Fit", Journal of Hirhar Eduation 6 . 358-60. Dotobor 1335 .

99 Conklin, Acnos. op. cit. p. 12

100 Desing, Minerva F. op.cit. p. 21 



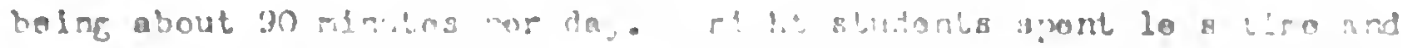

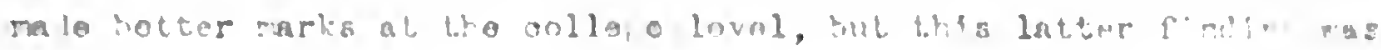
not conel olve.

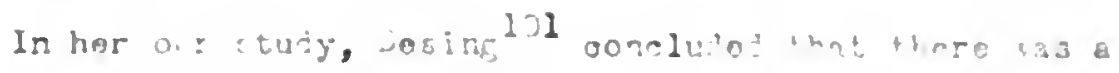

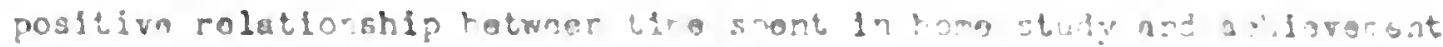

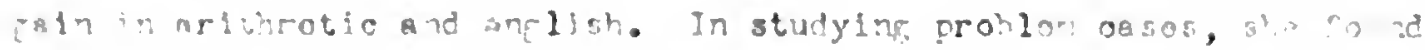

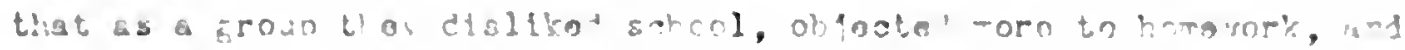

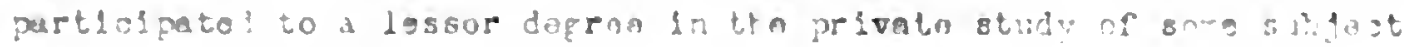
than eo non-problem childron.

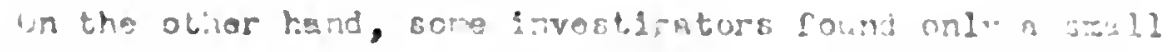

dois so of relationship botwoen stury ha' tha and tho arkievount of suporior pupils. My ray of 111 istration Bacon 102 as reportal :y

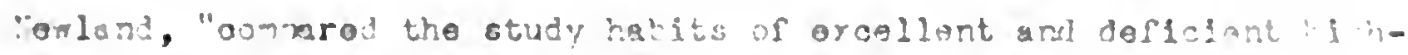
cetool pug1ls and cound the the supariority of tho hettor pry. wat not as zarkat as expotod."

101 IU1E. p. 107

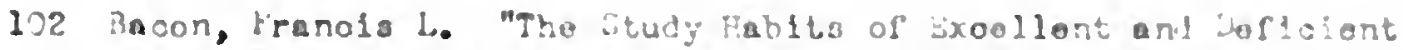

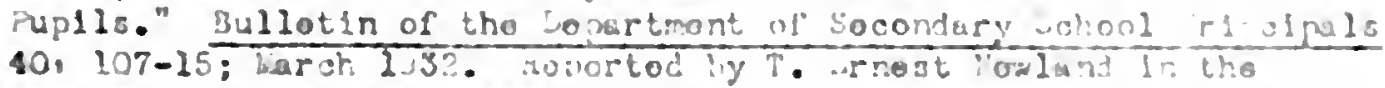
ovion of Educet1onal Kasourel, wap. III "Tho benally iffor," 2: 2ol. vuna 1341. 



\section{Schonl P.r tising gor siportor Punth}

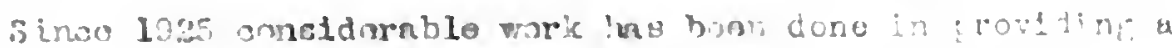

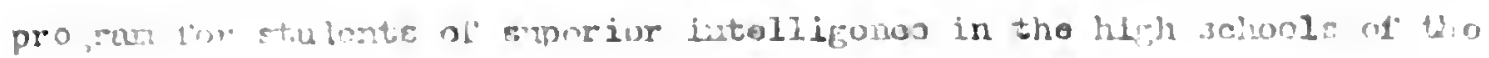

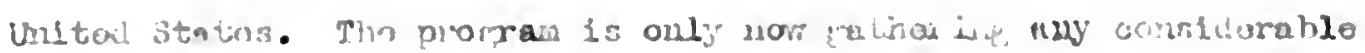

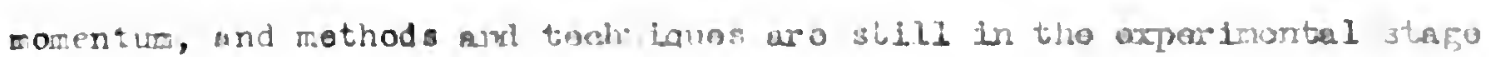
in most preas of this oountry. A sarrolo ai wurso of blu rosk bod ir, done is ovtinind belor.

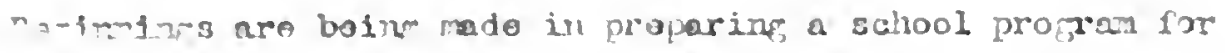
aproior minile in the United statos, bul us yot it is apperontly not,

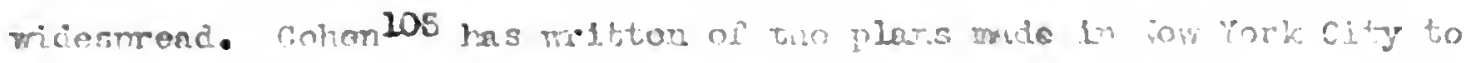

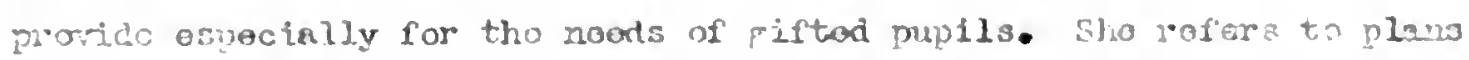
for seprofation, variablos in tho cumpiculum, iabits of industry, thoir

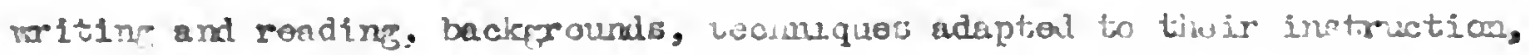

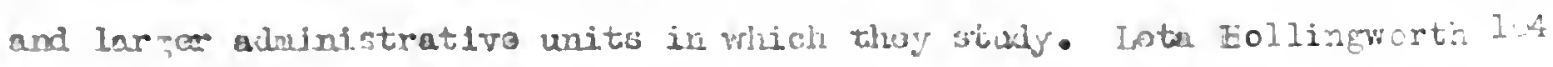
doacribos tho ains and activitios af tro "Torian classos" orcanizod undor

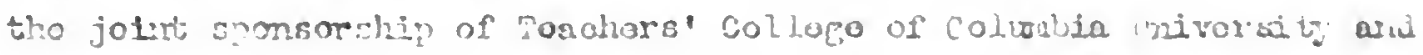
tho Ilov Yark Board of Eduation. Sinc liscussos curricular adaptations, grriclmant unite, and spociel activitios.

Sirilar studios havo boon borm in Baltinore, 105 clovoland, 106

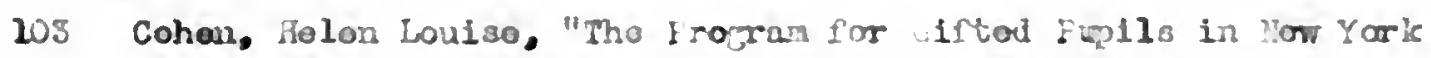

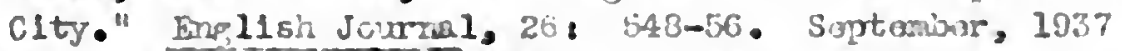

104 Hollinmorth, Low S., "An anichon's ontriculual por rapld learnors at rublio School 500 "Spyer School." Toachors Collg,o Rnomed, 39, 236-300. Jumary, 1938.

105 Thho Haltinoro Progen af Eduation for Phpils of Suprolor Abiliby". Ballimore liullotir of Eivcation, ve. 13, "1. "1 . 1- . Sopt., Octobor, 1झू.

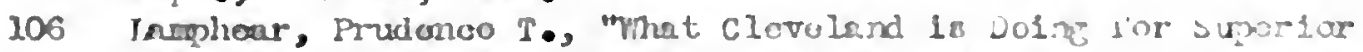
rupils". Finglish Journal, 2i; 723-728. 1!ovantar, 19a? 

Philadolphia,107 Columbur, Oh10,108 Buffalo,109 Rochester, Borkoloy. Apploton, N180.,110 Washingtan,111 Ranar C1ty,112 Los Anfolos 113 and other ofties in the Untted Statos. Th1s 1s a samplo of tha material avallable on the subjeot.

The Natl onal Eduoation Assoolation Rosenrch Bullot in for September 1941, 114 outlines a number of ourrent soliool provisions for eupertor sohool pupl1s. It sumarizes dhut is belng dono throughout tho Unitod Stuter. The concensis of opinion seerns to be that superior students should haves (1) spectally enrlched profrant of class work: (2) a oertain arount of rapld adranocment or aooeleration (not allowings the pupil to be placed with a group which is more than two years his superior in ohranological age): (3) more freodam in 5 oloction of olectives: (4) spoctal provisions for spoolal abliltics; (5) separato classes undor favorable oonditions: (6) superior teachers: and (7) partiolpation in extra ourrioular activities.

107 Boleau, Mara L. "Mothod Ucod with a High AU111ty Group" Soc1al Studi er, 28, 255-258, October, 1938.

108 Coj, Cenerieve. The Interests, Abll1t108, and Aohiovement of a Spocial $61 a 88$ for Giftod Chlidren. New York louchers Collugo, Columbia un versty, 1923. $194 \mathrm{pp}$.

109 Jones. Edward S. A Charter for the superior Student. Burfulo, Wor York. Undvorsity of Buffalo, 1936. 87 Mp. (University of Buffalo studies, Vol. 10 \#3, January, 1936.)

110 Osbum, Fi. J. and Rohan, B. J. Enriching the Currloulum for Giftod Chlldren. liew York. The lacsil 11an Corpeny, 1931. T08 Pi.

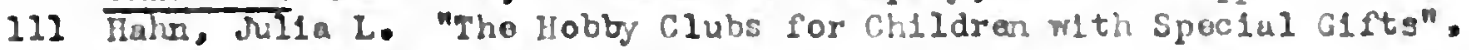
Bduational Lethod, 18, 21-26, October, 1938.

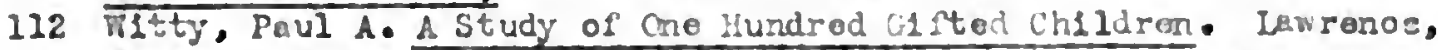
Kansas. Bureau of School Sorv10e und Rocoaroh. Univorbity of Ransas, 1930. 41 Pp.

113 Stodran, Lulu 4. Eduoation of Glfted Chl ldrua. Yonkori-un-iluda oa. Har York. Fiorld Book Compuny. 1924. 109 p?.

114 Nhanymous, "Hifh Sohool vothods for Supurlor Studuts" - liatlansi Eduoation Assoolation Rosearch Bullot1n: 19, 172-1\%, Septembor, 194I. 



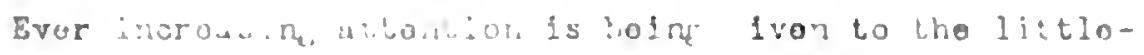

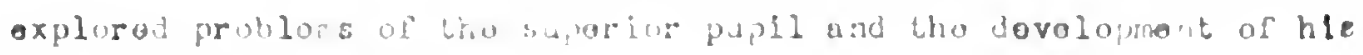
abl11tios and talonts.

\section{Sumarary}

In many rospeots tho litorature of pupll ahiovernent is arton not in acreement. Cortain hypothesis, howovor, aro fairly well accopted and suppcriod. It is conerally agreed that intelliconoo and aoriovomont aro pos ively rolatod, and trat the man oorralation is about .50 .

Recent evidenoe indicates that the chlldren of foroifn bor: parents achieve more in relation to to of intellizenge than children of nutive born parents.

Evidense indicatos that unirapp: farlly rolationshlps havo a deirimental offect on school achievement.

When gonerel health is considerod, thero seors to ho consideraablo ovidonce that the relationship betwoen health and school success is slient but positive and that certain types of physical defecte are zore rotardine than others.

Good study hahits soor to bo closoly rolatod rith sustuinod effort and superior achiovement amone superior pupils.

The whole effect of persomality on a chevement or schiovemont ratio is in guestion.

Socio-economic statuc aprours not to to inportant except whoro caser of railure and othar maladiustmont aro concernod. Tho punoral opinion, however, fevors a smal posilive rolationship betwon sooloooonomio status and achiovoment. 


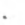


There is ocosoldarablo dieagrounent anomp irvostigators rogarding aohiovoment and paronts' oducation, cortain hoalth fnotor $\varepsilon$, how disoiplino, position in fanily or age of siblings, and cortain porsonality traits.

Tho Relation of this Study to Provious studios

As Desing 115 assorts

In cenoral, it may bo sald that studios of achioromont have boen too restricted in arce. The influencos which conceivably condition achievenent are 80 monorous that otudies involving only threo or four, as most do, are likely to prove inadequate for the interpretation of thoir orm findings - - Any otudy of pupil Erowth must contend with a varioty of lonown and unlenown factors, whioh may exort an influenco so preat as to mullify the results of the recoaroh.

In spito of, or perhaps boceuse of oonsiderable reseer oh on the relation of various elements to school succose, there exists littlo agrocment and considerablo uncertainty as to what eloments in tho hore, sohool, and ocmunity have a direot influenoe upon school progress. By selooting only pupils of high I. Q., tho euthor has atterpted to rule out theeffects of low intolligonoe upon achlevomont. Tho majority of pest studies on the socondary lovel have doalt with only a fow varlables. There 10 noed for noro extensivo otudies of achievomont, partioularly for pupils of superior intelligence, whioh will be comprohonsive onough to includo a larger mulver of olcononte. Tho presont otudy is intonded to bo ono of this typo, comprehensive, covering variables in two flolds-personality and hame baokgrounds which may bo rolatod to the aohiovernent of suporiar sooondary pupili. II5 Deaing. Linerva F., op. o1t. pp. 2s-24. 

It would bo desirablo to coaroh out and find tho relation of overy possible varlablo to tho disarepanoy botweon promiso and performance In pupils of superior intall1gonoe. Booause this task is beyond tho linits of tho writor's abilitios in the timo arailablo, the study has boon 11 mited to two flolds of related variables.

Th1s study differs rom other studios irrost1gating tho ractors assooiatod with tho varied aohlovemont of ouparior pup1ls in serveral rays.

Iwo relativaly new and improved moesures of porsonality havo been selootod to nosure cortain espeots of personality. By the use of the Whahborno S-A Invontory and tho Link Invontory of Activitios and Interests with the camo solocted group of pupils of superiar Intolligence, the writer hopes to establiah the existence of now essociations betweon the aohiovernent ratio and personality traits which might not otherwise have been brought out.

A muber of infrequently studied variablos bollered to bo essooleted with the disarepanoy between praniso and performanoo $f$ cr pupils of superiar intelligence have boon inoluded in this study of tho rolation of aohloroment with have backgrounds. Anong theso are hamo d1solpl1ne, marel verous urban ouvirownent, and oertaln aspocts of farily and ofbling rolationahipa.

Considerable work has boon done irvestigating tho assooiation botwoen achiovement an Sims s0010-000noulo status, study habits, anteoodonts' oountry of blrth, forelgn languages opoken in the how, parents' and pupll's hoalth and physical dofoots, and paronte' oduoation. 

For these variahing, wh Etudy adda a now viowpoint in investf ating, thase rolutionchips by usin; the achlovemant ratio. An Infrequently used rethod of holding intellipanoo constunt

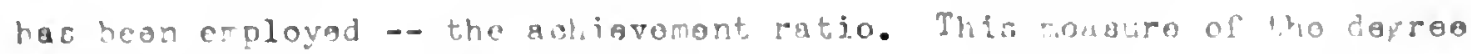
a pupll's oohcol performanoo is apuroach ne his promise has several advantaces. B! usinp, the $\Lambda$. K. It is nossible to inclide many cases which mi ht lave to hy dronred if falpin, or matchin so soze aystor of equating for intallirance is used. Dy fivine a measure of how yoll perforrance aproaches prorise for each pupil, the A. K. allows freator opportinity for dividing a veriatio to be studied into s atopories; and by matin it possible to obtain an A. R. for each catacory, the A. K.'s for the catocorles ma be ompared. In addition, the achievement ratio lands itsolf nicel: to statistical ca?:17, ton.

Care has boen taken to make this ample of pupils of suporior intelligance as represuntative of metropolitan hich sohool puntls as posathle. The pupils havo boan draw from all four conior high sohool rrades of five high schools in differont sections of Baltirore, Jaryland. These pupils have been geleoted so as to olosely anoroal, a grose soction of white rotropolitan high school population of Baltimore. Baltimore is itsolf a represertative oity of a roprosontativo state in tho initur states. 110

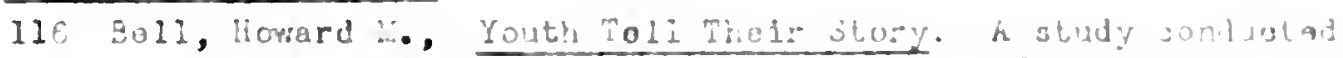
for tho Amorican Youth Comission, Amoricen Louncil on ztheation, iasilnpton, U.C., 1938. 275 0: • 


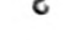


It is noped that as a rooult of those changes in approach to the problem. now data 111 bo unoorored that w11 make a oontribution to the flold of resonroh on superior pup1le. 



\section{SELECTION OF CASES AND COLLECTION OF DATE \\ OH THE CASES STUDIED}

A. Seloction of tho Cases for Study

School Populetion from which Ceses Wero Selocted

Critarion of Superice Intelligenoe

B. Collootion of Data on the Cases Studied

lleacures of Intelligenos

Seasures of Achiorement

Leasures of Perecenality

Measuro of Study Bablto

Leasure of Sooio-Eoonomic Status

Health and Physical Defects

Questionaire

Sohool Records 
CIUPTSR II

\section{SELECTIOH OF CASES AID COLLECTIO: OT DATA \\ OIf THE CASES STUDIBD}

A. Soloction of cabos for the study. School Populatica rom Which tho Casos Noro Soloctod.

Tho casos inoluded in this study wore seloctod froa 5 whito public socondary sahools in Baltimoro City. The canbinod enorollront of thase sahools totalod ampractintely 11,000 pupils. The pupils woro

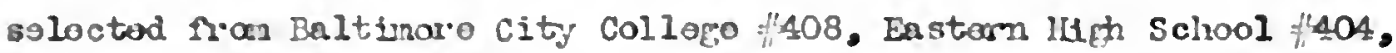
Floranoo Mirhtingula Junior High School $f^{4} 46$, Foroct Park Hifh Sohool i.406, and Southern Junfar-Sanfor High School ft70. These schools havo boen selocted to rejuesont the villto public hich sohools of Baltinore. Baltinora City Collogo $1 \mathrm{~s}$ an all boys' sonior hing school in tho northast soction of Baltinare, dravius pupile from all parts of the city. Bastarn Hich School is an all girls' senfor hich school in tho narthoast quartar of tho city, draring pupils from all parts of Baltimaro. Forest Park Mith School is a oooducational sonior high school in tho northrost quartar of Baltinoro, dravize puplls ohiofly from that sestion. Flarunoo III ghtinge Io Junior Ifgh School is a cooducational junior high ochool

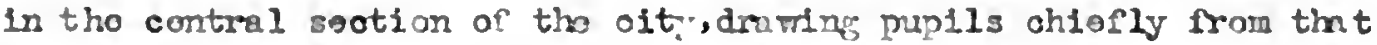
soction. Southern ILlph School is a ooducational junlar-sonior hich Bohool in tho south oontral sootion of Bultinoro drawing pupile ahiofly fram south Baltimoro. Unly mupils in frades $y$ thru 12 iran those Pivo sahoole woro includod in this otudy. Tho pupils fran Southern 14 ch Schonl oano fran a prodasinantly induatrial oootion of tibo clty: pupil. fran tho Eloranos Highinglo Hich School cano Iran a prodarimity 


$$
\text { . }
$$


camerolal coction of tho oity; puplls rrom Bastorn IHch 5chool and tho Baltinore City Colloge can from all soctione of the ofty, inoluding all classos of ocoupations. Studonts fron Forost Parle lif of School cono from a prodonimantly rosidantial soction of the citj and tond to be lanio those pupils noam Southorn IIf Golnvol. Tho objoot of this partioular nothod of eolocting tis cosos for study mas to obtain a carplo poprilation represontativo of the whito pupils of suparior intollifycos fran the soconiary sohonle (orados 9-12) of Baltimoro. Leryland.

Pupils maro asloctod fras tho vallous solfools on a voluntary basis vith thoir parouts' aconsont. It mast bo notod hore that 80 por cont of those invitod accoptod the iuvi fation and complotod tho data roquired for the invostigation. The bable bolow shows tho distributian of pup1lo by Bchools.

TABLE I SHONING IITELLIGEICE OF PUPIIS BY SCHOOLS

\begin{tabular}{|c|c|c|c|c|c|c|c|c|}
\hline School ITo. & E. & $10-118$ & I. . . & $20 \cdot 120$ & $I . Q$. & 0 and ovar & & $\tan 1$ \\
\hline & Bनys & Girlo & Bनy' & GIrIs & $\overline{\mathrm{Boys}}$ & GISIO & Boys ${ }^{-}$ & GIrlo \\
\hline (1) & 4 & 6 & 8 & 17 & 5 & & 17 & 23 \\
\hline (2) & 8 & 19 & 8 & 10 & 4 & & 20 & 29 \\
\hline (3) & & & & 64 & & 6 & & 70 \\
\hline (4) & & & 19 & 32 & 3 & & 22 & 32 \\
\hline (5) & & & 76 & & 8 & & 84 & \\
\hline TOTALS & 12 & 25 & 111 & 123 & 20 & 6 & 143 & 154 \\
\hline
\end{tabular}


Trilo 2 khows how tho pupllo cro d1atributod by crado, sox, And Invol of intollipanoo.

TABLE 2. DISTRIBUTION OF PUPILS BY GRADE, SEX AIT LEVEL OF IMTELLIOETCE

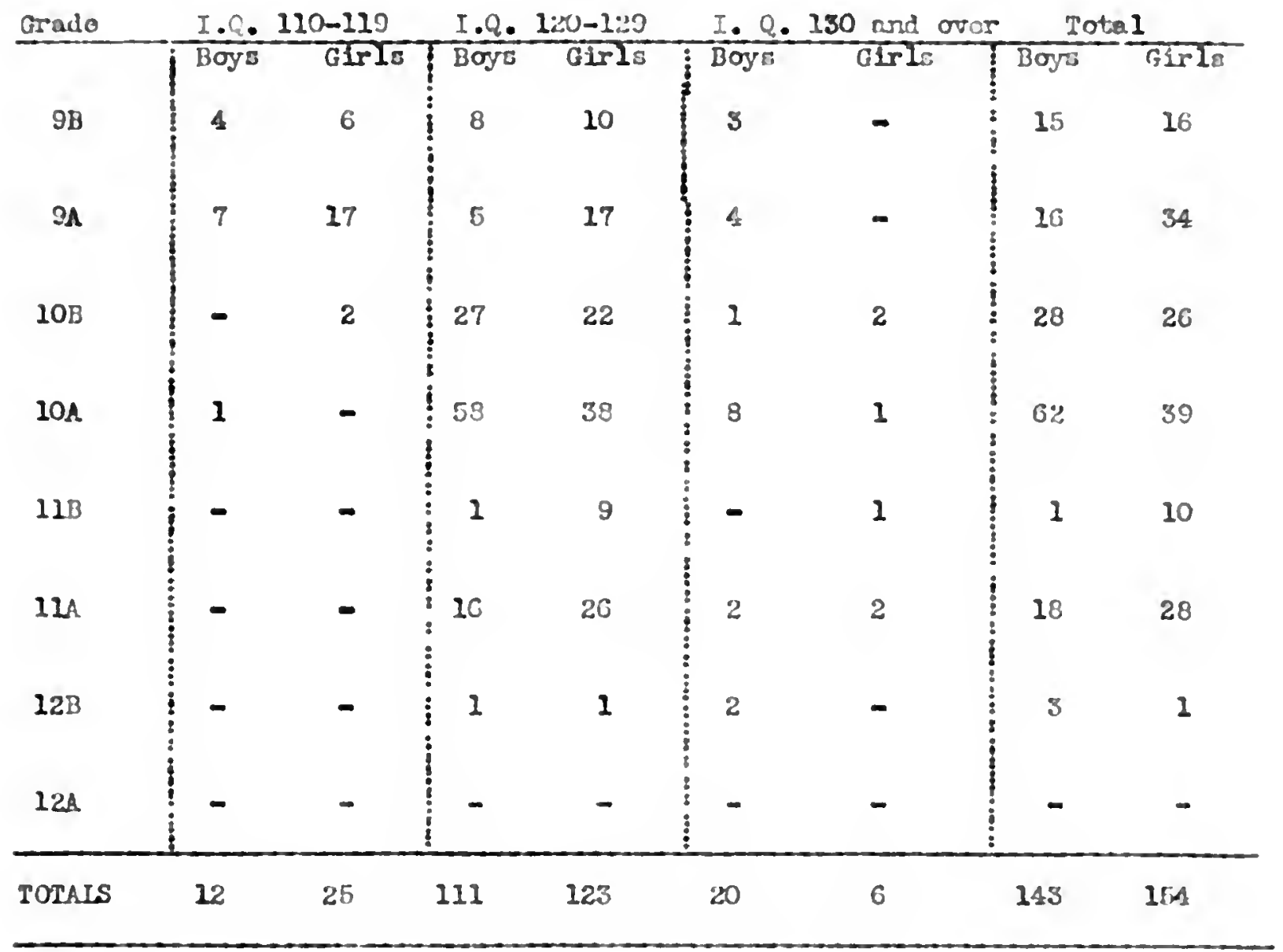


Gritarion of Imilligonco l"ar Soloction of casos

A prolininary counination of sahool rocards and intolliganoo quotionts of pupils in tho a jovo mantionod soccmary schonls ras mado bofare any woro invitod to partiolpato in tho stidy. Only those pupila from frados 3 to 12. Whoso otis intoll1fonos quotionts as rocorded by tho school wore 1:0 or abovo woro includad in tho proliminary invitation. Tineso pupils woro sivan tho otis Solf-Adainistoring Tost of lental Ability, hicher excominatlar, form $A$ and the lonmon Hulson Tost of Mental Ability, Form $\Lambda$, for Grodes 7 to 12. Those puplla who soored 120 or abovo on brth the otie and tho Harman jolaon Intolifgonoe Tasto woro rotainod in the study. A mall group of 37 studonts woro rotainod in tho study whoso intolligenco quotionts on the otis rost fell botween 110 and 119, Whth Intolligence quotionts on tho Homan lolson Test of 110 or above. This last group of pupils ware those whose otis intellifenoo quotients had droppod from 1 to 10 points ovor a parlod of no nore than 2 gons. It wa deoidod to rotain this group for basls of comprisan Whth those pup1le whose I. Q.' a wore oonsistently abore 120. Perhaps umeliability of tho teats usod would acoount for a conuldarablo part of this I. Q. drop. 

B. Collootion of Data ou tho Canos Studiod.

Lonaures of Intollifonoo

As has alroady boon nontlonod, twre group tosts woro uaod as mescros of Intelligonce, the ot1s and Hormon lloloan. Thaso prpils whoss I. Q. Ecores woro 1:0 or aluove on bath toste woro rotalnod in the study. In acidilion, 37 othor casos woro rotainod whose I. Q.' 0 on tho Otis miged betwoen 110 and 119, and whoso llonenon llelson I. Q. vas at lonst 110. It ras assumod, far tho purposo of this study, that pupils who obtained an intollifonoo quotiont of at loast 120 on both the otis and Hermon Jolson Intolligenoo Testr would be considered ns purils of suparior intolligenco.

All tho tosts, Inventorios, and quostioniros adminlstarod tc $\because$ ono particular pupil wore givon within a 10 day pariod. All five schools wore visitod one after the othor during the monthe of Fobruary, March and April, 10:2.

lioesuras of sohtoroment

The Lyara-Ruah High School Prograss Tost Fond All for Sonlor Hich Sohools 117 and the SonosmHarry lif gi School Achlovoraont Toot Form A for Seoondary Sohools and Collogo Entranoello woro tho Gonoral tosis ugod as moasures of achievomont. Thoso tosts moro usod intorahanfoably. Far purposos of carmarlion, standard scaroo woro found for oach tost. Ltyora-Ruah Achievazont Toat covors the Ploldo of Engliah.

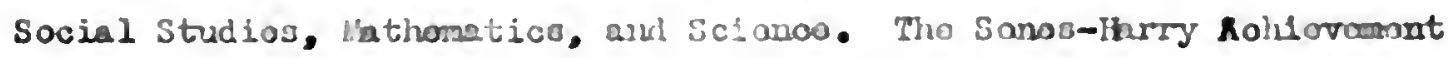

117 Uers, Charles E., Rtoh, Gllos 24. and Loofbouron, Grahais C. Wyers-fuah Hich Sohool Proprese Tost, Forn Am. Vorld book Company, Yonkaro-on-ludson, llow York, 1936.

118 Soner, F. D. and Finry. David P. Sonoo-Ihrry Hift Sohool Achiorecant Teat, Form A. Forld Book Compang, Yonkars-on- 
. 
Toet covors twe samo rlolds modor tho houdince of Languaco and Litomturo, Hathonatics, Social Studios, and latural Sclanci.

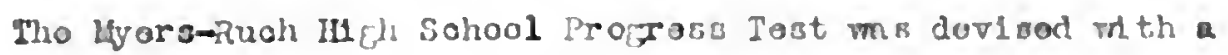
dorinito purposo in rind. hocardine to ito authors, 119 tho lhors-Ruah Hiph Sohool Propress Tost is an ahiowament tost Intondod privarily to : ieli a measura of motory of tho becio content of the averago high sohool courso of study. Tho soore for any singlo subjeot-mattor sootion is not intended to be considored as a reliablo noasure of natery of that subjoct ror any one pupil. Tho total sooro on tho test, howror, is a reliablo indox of ganaral achievonant for inclvidual guldanoo. Tho percentile nomas apply to onch grade for which tho tost is intondad and are based on approximately 9,000 cases from mmorous oamaunitios in the low England states, Virginia and Calisornia.

Tho iffer3-?uch tost was particularly dosireblo boonuso it may bo usod in conjenation with tho otis quick-Scoring Lontal Ablilty pests to find tha achioranont rat1o for aci pup1l - fran tablos alroady constructed bJ tho tost authors. The hyors-Ruch tost and the otis Gaxn tost waro atcinistared jolutly to noarly 3,000 unsolootad hish sohool pupils taken largoly from lith grado pupils in tho oltios of ilarth Caroline. Frou those data, tho Lyors-Ruch High Sohool Progross Toet sooros ard the Otis Geirna sooros wore convartad into stnnderd scoros. Those cooros, of couroo, can bo ocmparad diractly, and tho differancos botwoon thes at various points on the soslo aro oumparablo. Tho form used for corputilns atandard coores rass Standard acare SO, $10 \times$, whore $x$ is tho difforanoe botwoen tho individial scoro and the noan coors of tho

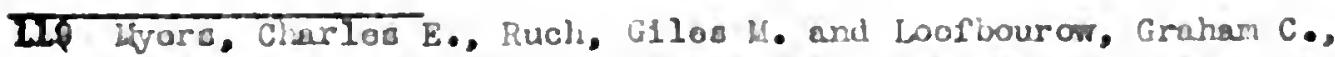
pyors-Puoh High School Proprose Toet, Lanual of Dirootions, 1938. 



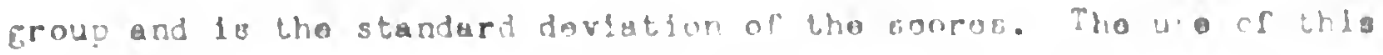

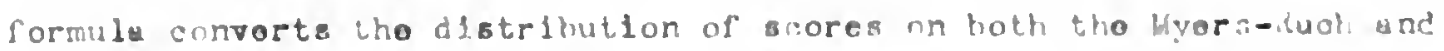
tho clie linma tests lito dsetrilutions torinf a roam of 5 , ard a

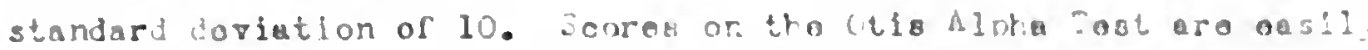
convertel to OLIs fama acores aid thonce to Standard ecoras. Frota the astlevement standard soorab anc tho intellipenco stulkrd scose an

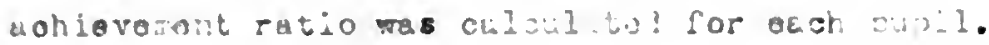

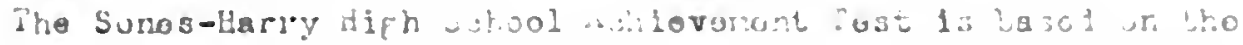

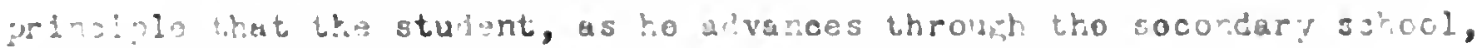
should bo contlmally adding to his furd ot rirational ingoratior. docording to tho lantul of U1roctions, i20

Tho main attorpt has buen to sariplo ris myv parin of lha

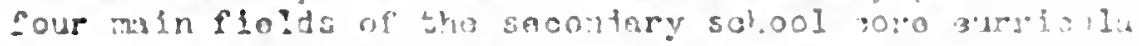
as $1 \mathrm{~s}$ consistont witt. socondury school toctine conditiuns and reliahla nessurn.tont.

Tho soct: ; and tho itoms of ogsh socton havo heon arrarat in orlor

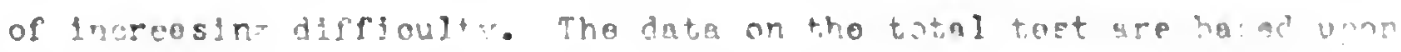

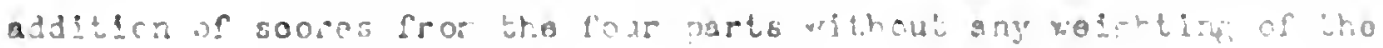
soparats gerts.

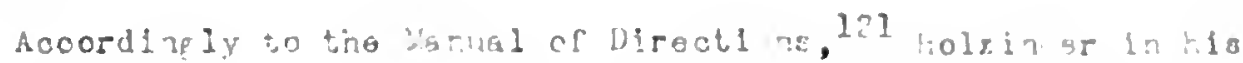

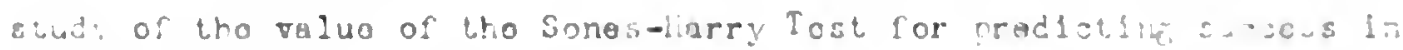
Who "zigersty of Uniouro atute" tret--

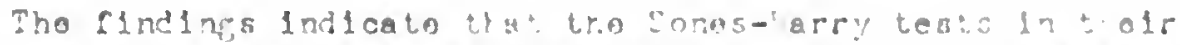
respoctivo loids have a poperallv hlptor prodlctive vuluo

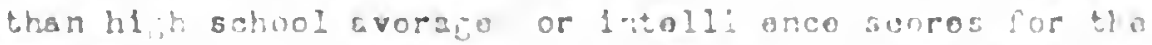
ostiantion of collop, work. It lo rathor romarkatlo that a

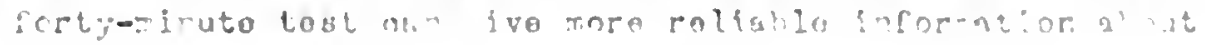

120 Sonos, "D. and isarry, Lavid t. Sonoa-harry rifh sohool dohdevomont

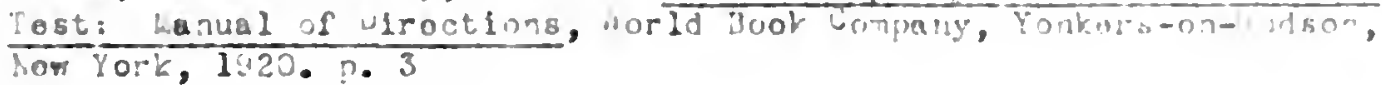


tho spert of wark a studant is 11koly to do in his restoman oourso than 18 givon by hlo high sahool arorago ..... an tho becis of theso findings it is recomondod that tho univorsity oontime to five tosts ouoh as the Sonos-Barry typo, and disoontinuo tho psychological excomination, if oano ourtalliont is nocessary in tho tosting progras.

Tho otandard orror of ostimato is avout 12 points basod on the 416 itous of the tost. The porcontilo noms aro givon for tilis tost a d they are for the liyers-Ruah tost and servo as an excollant mothod of oomparieon for the two teots.

School marks were also usod as a moarure of aohlovenont. Gonoral scholarahip avorago for tho September-Fobruary, 1940-1941 sonostor vas usod as a measure of achlowomont. Tho rwomber of cubject falluros during this term wore also usod in oorpering the groups oondidered in the study. In addition, tho failuros in semostars and semostors sleipped throughout the secondary school perlod wero considered as a measure of achievomont in comparing the varlous groups. Hoagure of Personality.

The two wasures of porsonality used in this study woro tho Nahburne $S-A$ Inventary (Thaopio Edition) 122 and the Inventory of Activition and Intorosts by H. C. Link and othors.123

Mahburno social Adjustmont Inventasy. Acoording to the Lanual of Diroctions, 124 "The primary purpoce of tho Pashburno SoolalAdjustront Invontory is to detervino the degroo of $800 \ln 1$ and enotional adjuotwont of an Individunl." SIx tralts aro soored soparatoly which hare oorrelated very ollghtly wh th 1 rtolliganoo and very highly of th

I22 Washbrano, John $1 \%$. Washburno S-A Invontory. Forld Book Campry. Yon'ser s-on-lhis on, how York, 19:0. !

123 Link, H.C. and othors. Inventory of $\Lambda$ c1trit1os and Intorests (for

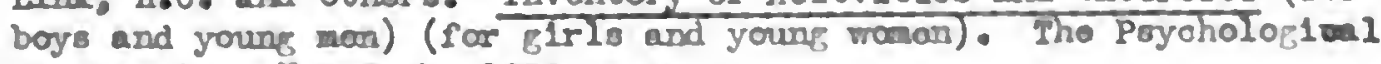
Corparation. Hew York, 1938..... us.

124 Washburno, Johr 11. Washburno Soclal-Adjustmont Invontory (Thasplo

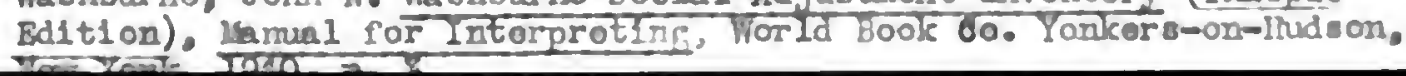


. 
soolel and actional adjustmont. Theso olx soparato soorob may bo ocosbined to give a total adjuetment sooro. Thros of the traits portain primarily to enotional adjustwent to other pooplo and to tho omviroment. The remining throo pertain to oolf-organisation and rogulation. Tho oleseifloations of the subtosto are Truthrulnoss, Fappinose, Alimation, Sympathy. Purpose, Impulso-Judgromt, Control, and W18hos, This Invantory wos set up to ollo1t rocponses with differonoes in adjuctacent but not vd th difforences in Intelligonos.

Ho question in this inventary was rotained unless thore was a reliable difforenoo botwoon the mmbor af maladjustod and the muber of woll-adjustod Individuals who answered it oorreotly. Vashbromo's125 defintion of adjustment was:

The oooperative, happy person who soemed to bo dealing effoctively with his onviroment was oounted voll-adjusted, the unoooperntive, disoontented, disorderly, estranged person or one who seemed to be unablo olther to alter his onviroment or to adapt himself to it mes oounted maladjusted.

Before the test reached 1 ts present farm, between 30 and 40 populations were tosted inoluding woll orer 10,000 individuals. As a further ohook on validity. It was found that the bl-cerlal $r$ ooefflolont of vildity 18. 90 , and the occrelation botween total Boores on the Inventary and Intoll1fonoe 18 nogligible - .07.

Porhapa ono of the major advantages of this toot 18 ito saroonins test of truthrulnocs. Thlo test fa truthrulnoso, composed of questions dovoloped by Hartahorn and lay, is dos 4 bod to roveal arolessnoss or meroprosentation in ropl100. Sprinkled throughout the 

Inventary, those questions are of such naturo that the apparontly dosirablo anowere Ind 10ate inaoouracy or lying. This oubtost on truthrulness overoomes one of the major objeotions to the questionnaire type of porsonality tost. Whare a rolatively $h f_{5} h$ defroo of untrutholnoss Is Indicated by the soore on this subtost, it is adfleablo to disoount the anowers or disourd tho paper.

Nashburne statoo in the Marual of Dircotions 126 that the ooofflotent of rollability as obtalinod fram a rotoat of 400 oollogo otudento aftor an interval of ono somoctar 16.92 . The probablo orror of an Individual's total scolal-adjugtment soore is 5, and tho coofflolents of roliablilty for the various subtests rango Pran .80 to .90. Thoso results all seem to Indicate thet the invontary is suffiolently reliable onough for individual diagnosis.

\section{Wink's Impontory of Activities and Interesto. Link's127}

definition of personality as rocorded in the lamal of Directionsi28 18 "persomality is moenced by the oxtent to which the individual has loarned to oonvert his energles into habits and skllis which interest and sorvo other pooplo". Link has alled this test the Inrentory of Activitios and Interests boceuso ho and his essictante folt it would bo Indolablo to display to those taldng tho tosts ouoh a titlo as Persomality Inventory or Porsonality Quotiont Tosts This tost, differing from the moshburne $S-\Lambda$ Inventory. Inoludos ovor 150 questiono rogarding habits and aotivitios rathor than foelings or cootions. Tho anowers to tho tost aro given by chocking ono of two or throe altarnativoe. I26 IbId. p.I2

127 Kank, H. C. "A Test of Four Porscality Traito of Adoloooente".

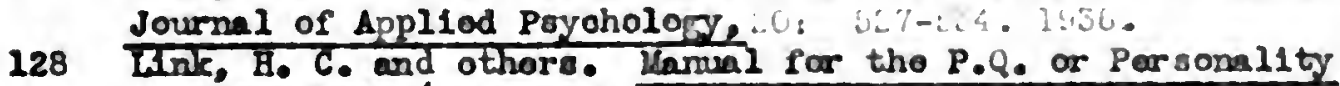
guotiont Tost (Inventary or hotifitios and Interosta) Tho Poyoholoblal Corporation, Now York, 1938. p.l. 

The purpose of the teot, as Givon in the llanunl of Direotions. 129 1s "to provide a masure of porconality for nomal atudonte and to provide this menoure in tarmo of a P.Q. or a parsonality quotiont". Beclde the total oocre fran whioh tho P.Q. 18 obtalnod, thero aro four oubtosto for the followine traits ar collectlons of habits, soolal Inltiativo, Self-Dotermination, Econanio Solf-Dotemination, and Adjustrant to the opposite Ser.

This Inventory wa desienod and otendardized for secondary school studonts. The validity of this tost has boon demonstrated in part by studies which cover 74 sohools in various parts of tho Unitod States. The opinion of pupils and of teachars appeared to havo a signifioant positive rolationahip to soores on the P. Q. tost, acoording to tho resulte of Thomson 130 and Dralos.131

The coofficionts of rellability of the boy's farm, when adainistored to 421 boys in 1936, was foumd to rango frae .75 to .88 for the various subtests and total scare. The Link thoary of poricanality, coocrding to the lamal of Direotionsf32 asounos that it is tho result of habits whioh oan bo devolopod and neasurod just as oducation now dorelops and mearses soholastlo habits. The P. Q. Tost attompts to onmernto and ovaluato the essentiel habits and olellls whioh oontributo to personality.

I29 IbId. p.I

130 Thoraon. ${ }^{\circ}$. A. "An Bvaluation of the P.Q. (Poreonality Quotiont) rost". Character and Personal1ty. $4: 274-242$. juns, 1938.

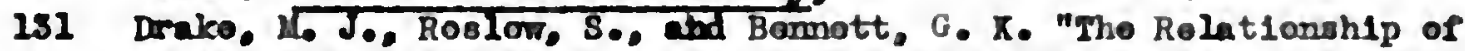
Self-Rating and Clasorato Ratine on Por ennality Iraitin". Journal

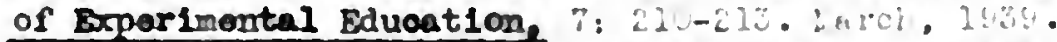

152 Kane, B. C. end othoro. Hanual for tho P. Q. or Poroomality Quotiont Tost. Pryohologial Corporation, Now Yark, 1958, p. 1-6. 

The distinotive fouture of this personality tost is that a personallty quotient nay be obtainod from the total tost acoroa. This personality quotient 18 intended to bo for porsomality what the intell1genoo quotient 18 for 1ntell1genoe. Norns for grados havo been establishod for both boys and firle throughout the 800 ondary oohool poriod. These nome for P. Q. 'B, a based on 3131 toste given to students throughout the united States. The P. Q. is found by using the formula, 133

$$
P \cdot Q \cdot=\frac{17}{\sigma}(X-M)+100
$$

where $\sigma=$ the standard doviation of the distribution for the sex and Grade group of the indifiduel on $S c a l e X$ and $M$ the mean score for the cex and grade group of the individual on soalo $X$, and $X$ the individual's coore an SOalo X.

Moasure of Study Habito

The messuro of study habits used in this study is $\mathrm{C}$. Gilbert Wremn's Study-Fibite Inventory.154 This inventory is composed of a 60 ories of otatements of oltuations, habls, and canditions whioh may affeot the use of etudy time and consequent suooess in sohool work and atudy. The tost to divided into 3 parto. The rirst part concerne note taking and reoding teohniques; the second and third sections conoern habits of oonoentration and sohool interesta, and genoral habls of work. The questions are answered by ohooking one of three differently welghted responser.

135 IbL. P. 7 .

134 Wrein, C. G1lbert und HoKeom, R. B. Study-llablts Inventory, stanford University Prose, Loland Stanford inlvorsty, Call fornla. 1934. 
. 
Aooording to the lanual of Directione,136 the inventory ia an orlentation device. Ite functione aro to 1 dontiry good and bad study haste of atudente. It Indicates which laulty habit is the most sorlous by wolghting more hearly study habits whloh have boen experlmentally determined to be eymptomatio of pood ocholsrship. The total score Indiostes the ceneral quality of the student's study habits. In genoral. high positive sooro on the Wrenn Study-Hablts Inventory Indloates good study hablts, whllo a high negativo sooro indloater generally poor study hablta.

Soo10-Eoonomio Statue

The Sime Score Card for Soo10-Economlo Status, form c136 was ued as the measure of Boolo-ooonomio status. The Soore Card, aooording to the Kanual of D1reotlans,137 was developed by Verner $K$. Sime in order to provide a eimple, convenient, and objectivo devioe for detemining the oultural, soolel, and oconomio beckpround fumished by the homes of eohool ohlldren. This 1s an exoellent dovloe for measuring one aepeot of the envitannent of ohlldren. Perhaps one of the greatest values of the Score Card 18 thet it is ablo to give eaoh pup1l soore and numorloal rating from 1 to 10 whlch lende 1 teelf to etetistioal oaloulations. The Score Card may bo ued for puplla of Erades 4 to 12 inolusivo.

136 S1me, V. K. Score Card for Soolo-Eoonomto Statue. Form C Publlo School Publ1 Thlnf Company. Bloconlngtrn. IIIInols. 1927.

137 S1me, V. U. Soore Card for Soolo-bo nonle Statue, lanual of DI rectlone Publlo Sohool Publiahing Coapany, Bloowington. Ill1nolen, 2827. 
Fealth and Plyalcul Doteots

Eacl of the pupile In thls study was, ivon a spocial thorourh physionl examination liy the bohonl physiclan. A rocord nas bapt of tho coneral farliy health history, studont'a heulth history, ard sta Coneral health examination. Particular caro was tu. y the school dootor in these examinations that no physical dofeot rould bo overlooked. Special attention was fiven to the searoh for defoots in sifht, iearing, speech, noso wn throat, mouth imcludinf teoth, wolpht, any motor dofocts, heart, lungs. In other words, tho examination fivon covorad thorodghly all of those itoms listed on the physiogl examinstion report whith the Divisicn of lioalth and Pnysical Education of the Departirent of tuducation of the City of sultimce requires for eaoh pupil. It was arranred oo that the school doctor rade his oxamination withir 5 deys aftar the pupll had oompleted tho sorios of tosts, inventories and questionnairea. Luestionnaire.

A Eeneral questionnairo was filled out by each pupil. This quostionnalre covered a varlety of fields, and wab somethjng of a miscollanoous dicratl containine 70 quesilons. Iho quostonneiro suppliod information regarding, parents' and Erundparents' country of blrth and wether any foreien lancuages wore sookon in the homo. Information was also supplied refardlne penoral family and sibling rolations for ach pupil in tha atudy. It includod quastions involpln whethar tho pup11's family woro saparutod or not, wlth whos tho pupll was

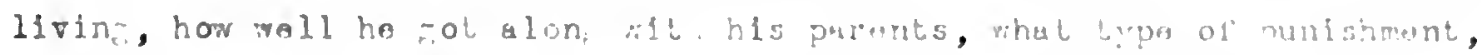
11 any, was adminictored, how many brothers and sistorg lo hat, his 



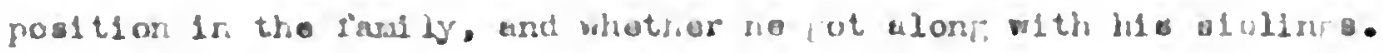
Inte on the-conuming autivitios such as reuroutlaml uotivitlos, church sotivithes, whtur scr.ool jald anploymeit motivitict, howo vork

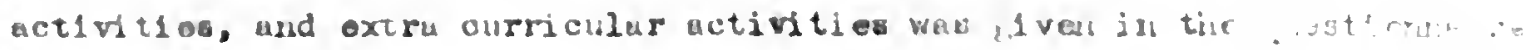

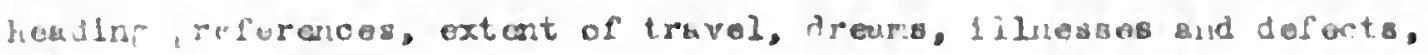
adrittod led halds, and bunk ucoounts ore other 1 tome covered in the questionnalre. Iri uddition, verlous 1 ters rogurdine wohool such as

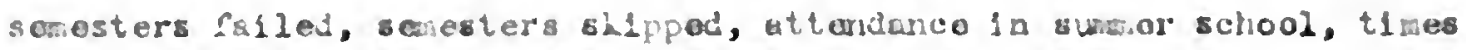
on the honor roll, intents ons roparding udditional sohooline, preferances

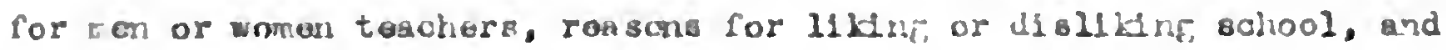
marks in school conduot were iroluded. A copy of this "wosticrugtre w112 be fourd in the hppendix.

Schoni hocoris

The acholarship record ourds givine, sibjoct rurks, oonduot and effort murks wa woll as uttandarca records woro roforral ic.

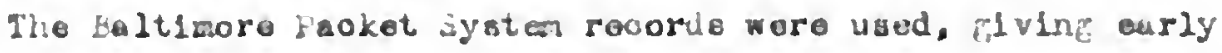

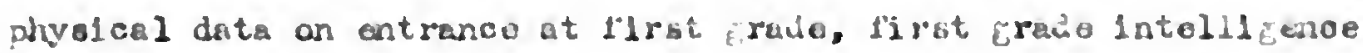

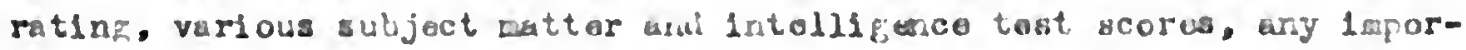

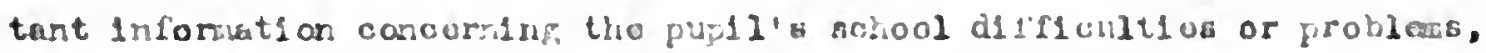
curds shor:1ni puill's airi in 11fe, vocutional choloe, lnterosts, scholarahip rocord fron Il rot phis ip to hato, anci ary othor futtors

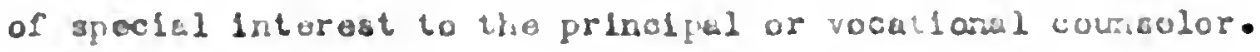


. 


\section{ClLPTLK III}

IKEATL LW I Ol' IHE DATA

A. Compilation of a Lastor Chart Including All the Data Colloctod.

B. Caloulution of the Achieverient latio for Lech Iupil.

C. Statistical lothod Used in Comparing Achievenert Futio vith. Each Voriable - Analysis ol lariance.

D. Division into Achlevement hatio Groups. 

CHAPTER III

TYFiT:TT OH MH: DATA

i. Compjetior of a lisater Chort Insiding All Dala

A mastor chart. war a wlei from tro individual data cards, tosts scres, on? prastinnapomidita. Coldele dala on oush pupil

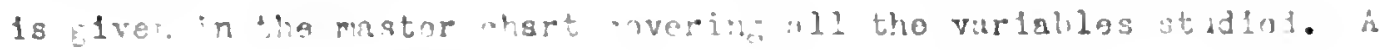
portion. of the mastor chart is shom in the fopondix.

B. Calculation of tho ichiarazant irtio.

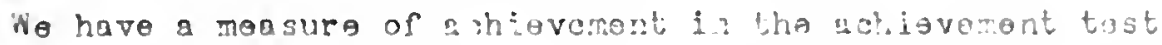

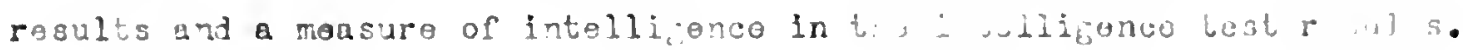

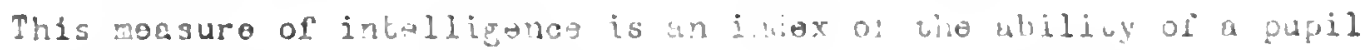
to master tha poneral taiks of Iife. It ls also a reasura ul itrorai

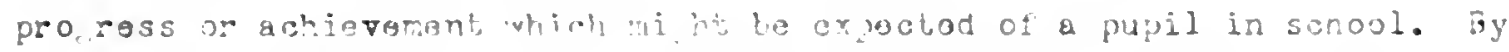
comblulne tho nossures of intalliconce and act invaluent an whievariont

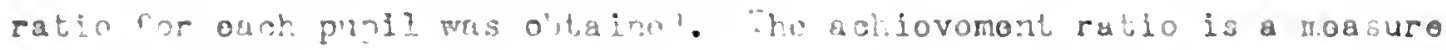

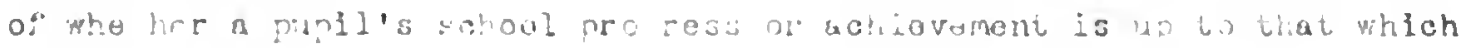

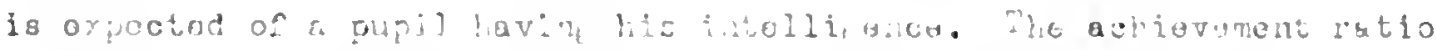
may also be cundiloras as a neasure indicatime whetiner a pupil's schrol pro-rese is poorer than, $4 \overline{4}+1$ ho, or hetter thun nis ronoral

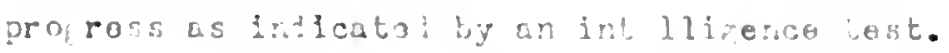

It is possitlo, tut infraguant, o u puisl to be propressine

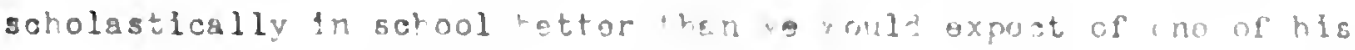

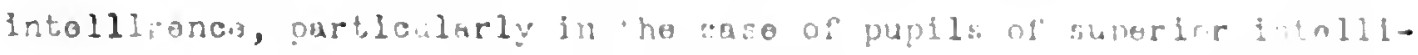

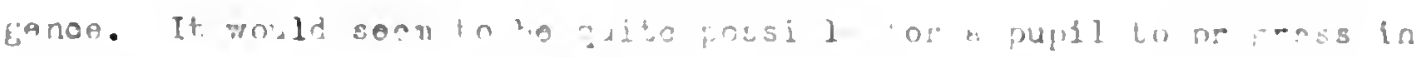
sohool batter than wo mifht expeot from his non-school procroce or a 

measure of 1t. Lutio frequontly, of courso, tho ravorso in rilo; a puyil's promise very oftan exooeds his performanoo.

The achievement ratio u ed haro is bhen a nousure of hor nall a pupil's performanoo in school as mokgurod by and a lavomont tost approachoo ( 1 s le.s thar, oqual to, or hottor phar) hie pro-130 as neasured by an intelli,ouce tosh. This achiovoment ratio was arrived at in this mannor: the achiovament tost scoro ras chanjed to a standard scoro. Tho intelli,onoa tost soore was changod to a standard

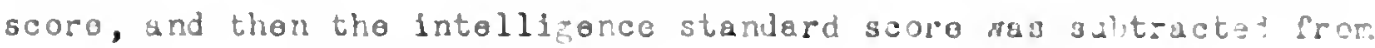
the a oirievenont standard score.

where the achievement ratio wus positive, it was an fidicntion that tho pupil was achlovine botter than mifht bo oxpoctod of a pupil having his I.a. Where tho achievement ratio mas norativo, it was assured that tho pupil was not echieving up to his promiso, a vory hi, hegative reault indicated that ho was achioving considorably below his promiso, a small negative sosult that a pupil ias achiovin sliptly belut his promiso.

In Chupter II under liesures of fochiovoment the method Lyors and Tuch havo usej in ariving at this masure of performanco In referon'a to promise is tentionod.

Whon the achievernnt ratios collootod by ivera and kuch for all pupils are comparad with those collootar in this stud tor

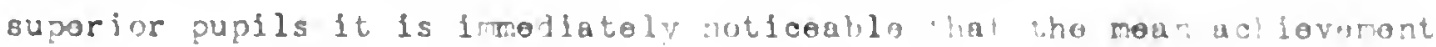
ratio for these suporior pupils is corsitoruliv bol w bire z.gro

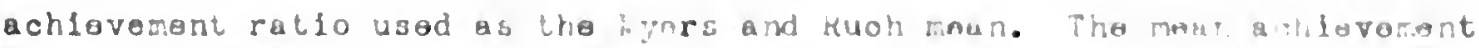
ratio for these 297 pupils of suoerfor intoll, onoo was -7.74 ; 




\section{Wothod Used in Showlnf the Helutionolilp of Achievenant hat to Esoh Varlablo}

Arter tho achiovenent ratio had buen oaloulat od for oach puoll by subtracting tho atandard coro far fitelli-croof fron the standard score for achievenent. the rolutionshlp botween these achicveicrt ratios and various varieblos wore deteminod. The writer was invostlrating the rolationshp of aohievenent ratio witi, porsonelity test scores and home beokeroundo. The Washburno and Lini pursonailty subteat and total scores served as one roup of variablos. Variables selected under home baokfrounds irclude those covering, parent-pupil relationships, the pupils'antecodaute' bi rthplace, perent and pupil hoolth, sibling relationehipe, home study conditions, and Eeneral hane environment. Below is an alphe vetio ist of the variabless

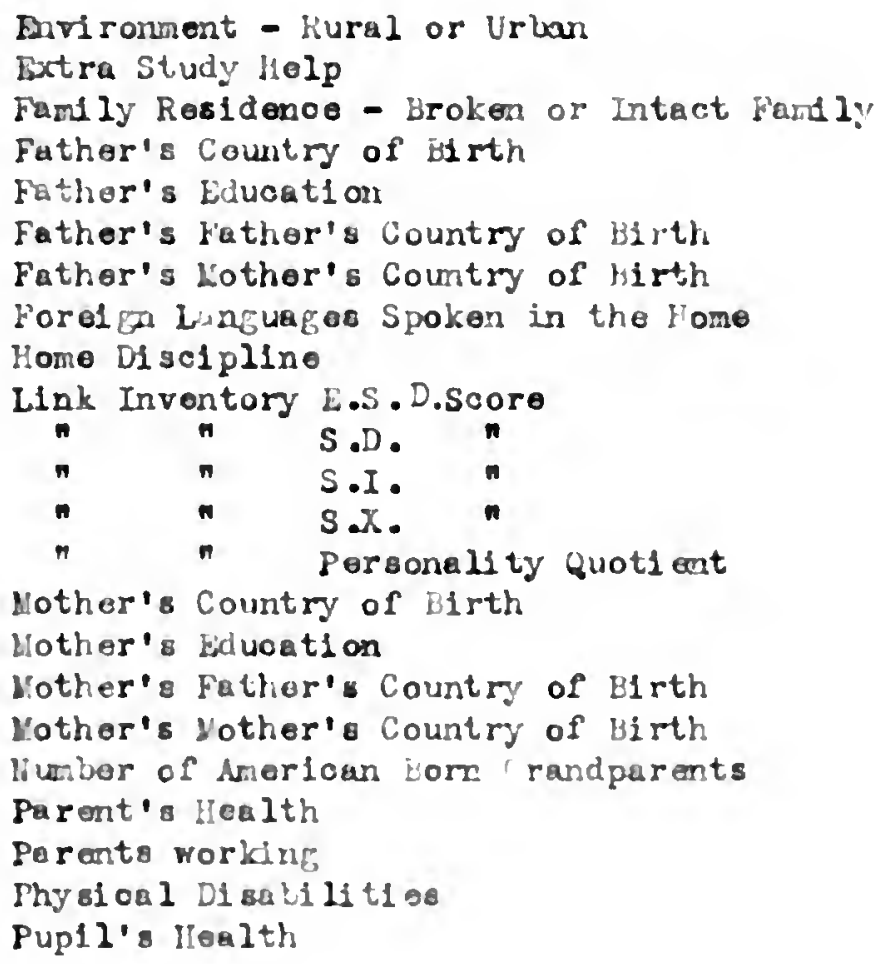



Siblinga

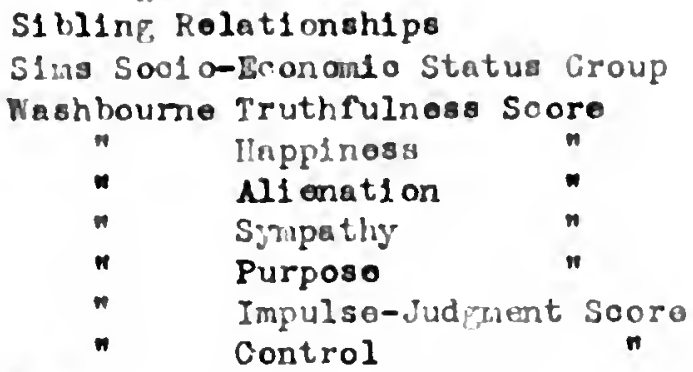

Vrans Study Habits-motal Scoro

Bact of tho abovo varlables had under it soveral subclasalflcations. These subclassifiotiono wore dram up to be mutually exolusive.

A gruph showing the relutionship of achievenont rutio with each variable and its oategories or subclassiflcations was made. Separate grupho wore made for boys and firls as woll as for the total group.

The method used for oalculating the rolationship botwoen the varlables and achievoment ratio was by analysis of varianoe. by using the F tost, 139 it was poseiblo to deteraino whether a sipnlficant relationship existed between any one of the experimental variables and the achiovoment ratio. Unless othervise noted a sigilcant relationship means signifloant at the $1 \%$ level, that $1 \mathrm{~s}$, there are 99 chanoes out of a hundrod that a rolationship exists. Where the $F$ teat indicatod that the relationshlp wus slpnlilount at tho live por cont level, that is, there are gf chanoos out of a lundred that a rolationship exists. the relationshlp was also considerod sifrlfioant, but whonover suoh rolationships woro roforred to, this is notod. As Lindquít 140 says, it must bo remombered whon usinf. the ly toot that the doproo of

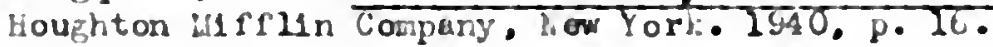



relatianship is not ivon, whi th $t$ whl lo a relutionship may bo consietently present, it may at the same time be smali.

B. Division Into Aohl ovencuit Ratio Groups

The data wore asaigned to $81 x$ achievement ratio proups is listod in Table No. 3 .

As oan roadily be seen there were 143 boys and 254 Girle, making a total of 297 oses in all six oohleventent groups. There were only 2 boys in the hiphest achlevemant retio group 10 to i2; there were 49 oases in the 0 to 9 froup; 149 osses in $11.0-8$ to 0 group: 23 oses in the -10 to -12 group: 11 cases in the -20 to -29 group and 3 firls in the lowest aohlevement ratio group of -30 to -39 . 

CHAYT ER IV

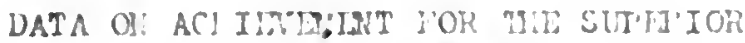

PUTILS SEUDIED

\footnotetext{
A. Data on Aclisevenent l'est Scores

B. Deta on l'ental Af,os

C. Data on Intoll1Eenoe quotj ent

D. Duta on Achieverient Rutios

E. Deta on Comerul Scholarahip Averepes

F. Data on Corduct and pifort larks

G. Date on jemasters linilod

H. Deta on Suresters accelerated

I. Summary
} 



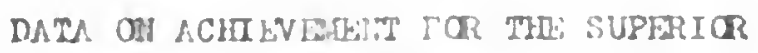

PUPIIS STUDIED

\section{Data on Aahiovariont Tost Scores}

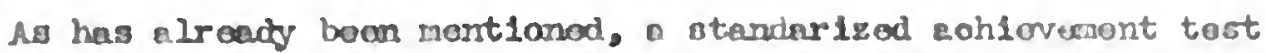
we pives overy pupll and the gooros alungod to standard sooros. Trblo 4 shors it distalintion of those soaras.

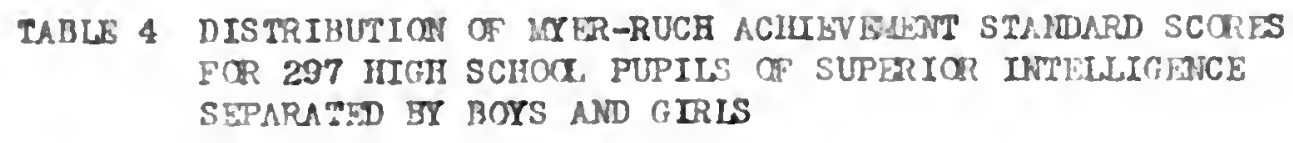
SEPARAFID BT BOYS AND GIRLS

\begin{tabular}{|c|c|c|c|}
\hline $\begin{array}{l}\text { Aclilovanant } \\
\text { Standard } \\
\text { Sooros }\end{array}$ & $\begin{array}{l}\text { RUCBER } \\
\text { BOYS }\end{array}$ & 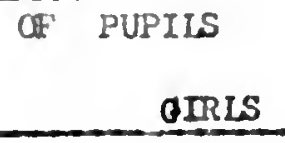 & $\operatorname{ToT\Lambda }$ \\
\hline - $72-79$ & 10 & 3 & 13 \\
\hline $68-72$ & 10 & 11 & 21 \\
\hline $64-\infty 67$ & 30 & 19 & 39 \\
\hline $60-63$ & 26 & 25 & 49 \\
\hline $56-59$ & 31 & 23 & 54 \\
\hline $52-56$ & 23 & 18 & 46 \\
\hline $48-51$ & 8 & 22 & 30 \\
\hline $44-47$ & 5 & 16 & 21 \\
\hline $40-43$ & 1 & 5 & 6 \\
\hline$\cdot 20-39$ & 6 & 10. & 18 \\
\hline TOPAL & 143 & 254 & 297 \\
\hline МڤAU & 59.2 & 55.9 & 57.5 \\
\hline
\end{tabular}

In this distribution as in nany subsaquest diatributior tho stop intearnis at the actrenos of the distribution aro coureonod wherevor the 1Topuonoles of the intervals beocino proportionally vary sanll. 

Bxamination of the distribution of achlevement scoros in Tablo 4 above indioates that the distribution for the tois group olosely appronohes normal." bolag a bit skowed to the loft. The mean achlevement standard score for tho total group 18 57.5. The modal interval is $56-59$ and the mode 1857.6 .

The distribution in Tublo 4 showing the achiovemont standard ccoros for the boys is skewed oonsiderably to the right. Tho muan for this distribution is 59.2 while the mode is 57.4 .

The distribution of Girlo achiovenent standard scores in Table 4 is b1-modal at the 60-63 and 66-59 intervals and was considerably skewed to the left. The mean for the distribution is 55.5 several points below that for the distributions of the boys or the total group. It is quite erldont that the boys oxcel the girls in mean achlevement standard ocores. The distribution of all wohievement standard scores is left skened beosuse of the preponderanco of low scores in the girl's distribution.

This superlority of boys over girls in echlovenent as messured by a standardized achiovement test is seldom reported by other investigators.

Desing 141 reported on four studies comparing tho achievement of boys and girls. In each study boys were found to be superior to girls in ochievement a measurad by achievement test scores. In the same section, however. Deolng reported other studios favoring firls I4I Dosing, Minerva F. op.o1t. pp. 13,14.

- nomal has boen inadvertently used hore and in the following pages where symetrical was the word intended to desoribe the appearance of the distribution or curve. 

whore aohloranent as measured by atandardized tests 1 s conoerned. Thio 18 1 liustrative of the literature on the subjeot.

B. Data on Montal Areo

The mental age for each pupll wao obtalnod from the otio intelliganoe test soore. Table 5 glves distributions of mental ager by monthe for the boye, Girla and the total group.

TABLE 5 - DISTRIBUTION OF KEITAL AGES IN MONTHS SEPARATED FOR BOYS AND GIRLS

Mentel Apo (in months)
NULBEE OP PUPILS

Boye G1rlo

43

61

50

254

297

FotAls

243

224.9

223.3

MEAT

82

1

243 Totul Group 73

81

The total distribution takes the form of nomal curvo a bit sewed to the left. The nodo for the total distribution io 224.4 and the mean is 224.1 ( 18 yro. 6 mo.)

The distributica of mental ages of the boys approaches the normal rather olosely with a noan of 222.9 and a mode of 224.8 . This skomess to the right is noglleible.

Tho distribution of mental afes of tho girla is oloso to normal, a trifle showed to the loft. Tho menn mental ago of the F1r2. 1.223 .3 and the mode 18 224.2 .

The boys and pirls inoluded in this otudy differ 11 ttlo 
In moan mental apo but the silght difioronoe that does oxd st favors the boys. Thls differmoo may in part aocount for the superiority of the boys over the girls in mean aohievenont teat scoros.

\section{Data on Intelligonoo Quotiante.}

Tables 6 and 7 show the diatributions of otis I. Q'e and IIenmon-Neloon I. Q.'s.

TABLE 6 - DISTRIBUTIO: OF OIIS I.Q'O SHJARATED FOR BOYS NID GIRIS

\begin{tabular}{lccc} 
Ot1s I. Q. & BOYS & MULER OF PUPILS & TOT AL \\
\hline $130-37$ & 20 & 6 & 26 \\
$128-29$ & 15 & 13 & 23 \\
$126-27$ & 15 & 16 & 31 \\
$124-25$ & 29 & 27 & 66 \\
$122-23$ & 31 & 32 & 63 \\
$120-21$ & 21 & 35 & 56 \\
$118-15$ & 5 & 12 & 17 \\
$110-117$ & 7 & 13 & 20 \\
TOT NLS & 143 & 154 & 207 \\
LEAN & 124.4 & 122.9 & 123.6
\end{tabular}


. 
TABLE 7 - DISTRIBUTION OF HENXON-NETSON I Q '. SEPARATED FOR BOYS AID GIRLS

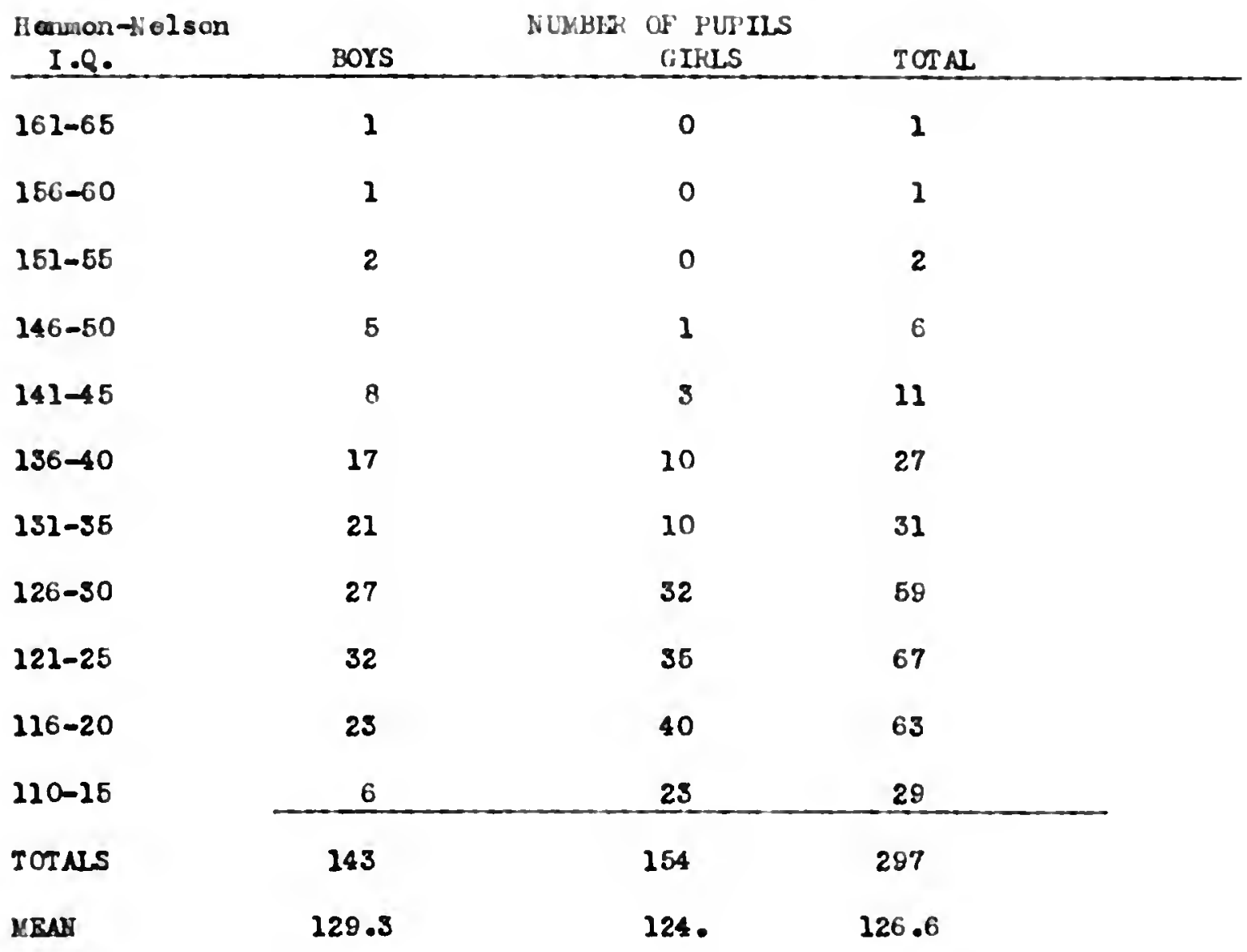

The distribution in Tablo 6 br otis Intellfonce Quotiente for these ouperior pupilo closely approachea normal distributian. The rsean Ot1s I.Q. for the total group 1s 123.6; the node is at praotioaly the same point 23.0 . Apperently the total otia I.Q. distribution $10 \mathrm{e}$ tit, shered to the right. The distribution of

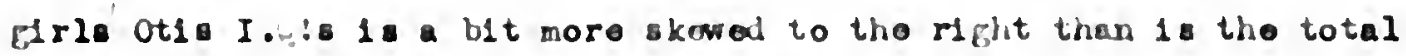
d1 atribution. The mean Ot1. I.Q. For the pirle 18122.9 while the mode falle in the 120-121 interval. The distribution of boy ot1. I.Q.' 1. akewed to tho right with the moan at 124.4 and tho modo at 123.2 


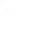




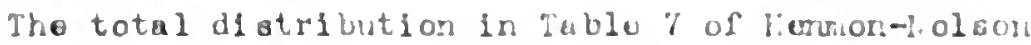

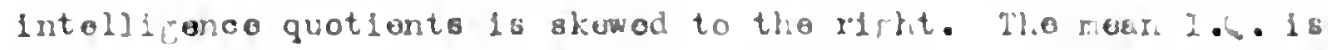

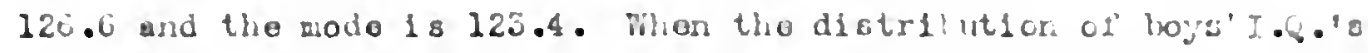

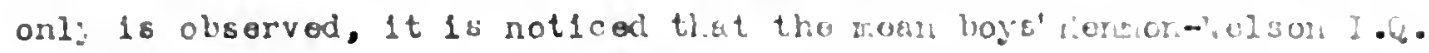
Is $12: .3$ ard the rodo is 123.7. Evddontly the boy s distrintion is conslderably skewed to the right. For the firls distribution, there is a defind to skewness to the riflit suturly us proninmoed as that for

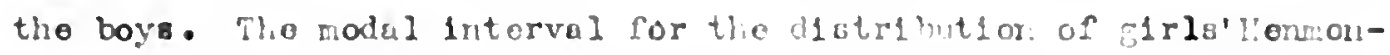

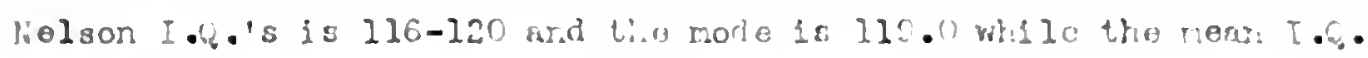
is 124.0

Whon ono lools at the noan I.Q.'s in Thblog 6 knd 7 , It is epperent that the boys surpasa the wirls irt roar. I. A. In difference in otis I.Q. points botwoon tho voys and cirls, however is rather srall, only 1.5 points. The difference botwer. the bo:s and girls on moan Ilenmon-:ielson I.Q.'s 1 s moro pronolgced, 5.3 points, lut this too say bo due to chanoe. These results acroo with those fiound by Teran 142 and others. According to Stroud, "howovor, oarlier predictions with respoct to tho absence of sex difiercioes lu intellectual status heve been Indicsted. This oeeninr contradictlon may bo accountod for by the fact thet Tencris's rosults were basod upon intellifence scores of superior puplis whlle those raportod by stroud wero besad on unseleotod pupils.

Thoso duta in forioril indicate to us that tho puplis selocted are of superior intoll1 renco.

142 Torman, L. L. Genotio studiog of ciens us, lental and phrsical Iralts of 1000 cilftod childran. Stanford ind veralty press. Fulo ilto, $1925,1.559-60$.

143 Stroud, J. B. "Psycholopioal Tosts and their Usos," Rev1ow of Edvoatlonal kesoarch 11,34, Fourisary, 1541. 

D. Data on Achiovanient hatioe

A distribution o: achioverumt, ratios lis i.1 vor bolow in

Fable 8.

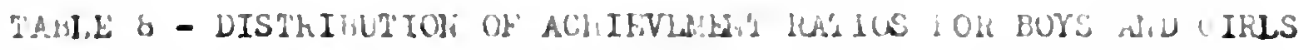
AND TT:E TOTAL GROUP

\begin{tabular}{|c|c|c|c|}
\hline $\begin{array}{c}\text { Achi overent } \\
\text { Rat1 or }\end{array}$ & BOYS & $\begin{array}{l}\text { MTIIS } \\
\text { CIRIS }\end{array}$ & "OTAI, GROUP \\
\hline 10 to 29 & 2 & 0 & 2 \\
\hline 1 to 9 & 20 & 17 & 49 \\
\hline-9 to 0 & i? & 72 & 149 \\
\hline-19 to -10 & $\Sigma 4$ & $1=$ & 23 \\
\hline-29 to -20 & 4 & 7 & 11 \\
\hline-39 to -80 & 0 & 3 & 3 \\
\hline TOTAIS & 143 & 154 & 297 \\
\hline LEN & -5 & -9 & -7 \\
\hline
\end{tabular}

7\%o stidy of the Ireciuenc? distribution of the achievecient ratios in iable 8 shows thut the uchlevancnt for boj:, ir is and total Eroup all fors distributions skevod to tho lest, with the newa for the total group falling at -7 , the raun for tho bogs at -5 and for tho grls at -9 . Tha mode for 11 threo krougs fulls in the o to -9 interval.

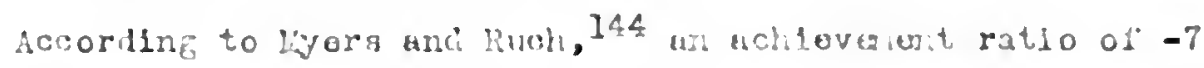

(2.e. a differenco of 7 wtandard score point betwour the echievonent ecoro and the intellifuce score) wnuld occur by char, about 13 tinec

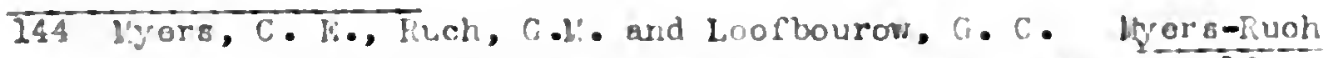

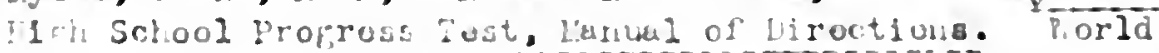

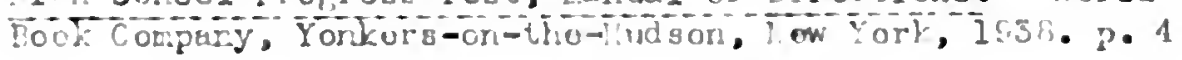



in a hundred. Thls is bas on tho calculation that the probable orror for tho lyors-Ruch tost scoro 183 atendard scoro polnts. For tho girls an achiovomt ratio of -9 would occur by ohanoe about 4 tines in hundrod, and for tho boys an achioveriant ratio of -5 would have about 28 chanoes in a hundred of poourring, by chanco. It wolld 80 em from tins that the ifforonce botweon tho achiovomont scores and the intell1pence ocores for tho girlo is likoly to bo signifioant $4 \mathrm{~s}: 4 \mathrm{i}$

3 times its probable error. Tho difference botween the achievement scores and the intolligance scoros for the boys was nuch lower, and consequantly for tho totul group this differenco was lower than it wa for the girls, and ifith hove resulted in both of these cases from chance errors.

In all probability. tho difference botween achiovent standard scores and intolligence standard scores for the boys and total frou as well as for the grlo is a roul differonce which cannot be disrecarded.

These date on chilevement ratio merely verlfy a previously conceived hunch that superior puplis are not prokressing in school noarly as well as thelr intellipenoo scores indicato thoy can. It appoars from the data piven in tablo 8 that when school aclisevement is mossured by a stundardized achievenent test the boys surpass the Elrls in wean achlovement ratio. The clief puriose of this siludy wil bo to find sone of the factors asoolated wh the low ablovenent ratios of these suporior pupl is, both boys and pirle. 
E. Data on Genoral Scholnrsh1p Averagoa.

Table 9 gives a distribution of data on Scholarahip Avorages.

TABLE 9 - DISTRIBUTION OF GENBTAL SCHOLARSHIP AVERAGES FOR IEE SBMESTER COMPLETED PRECEEDIRG THE INVESTIGATION. SEPARATED FOR BOYS AND GIRLS

\begin{tabular}{|c|c|c|c|}
\hline $\begin{array}{l}\text { Goneral } \\
\text { Soholarship }\end{array}$ & \multicolumn{2}{|c|}{ NU:BER OF PUPILS } & \multirow[b]{2}{*}{ TOTAL GIOUP } \\
\hline Averages & BOYS & GIRLS & \\
\hline $90-100$ & 12 & 10 & 22 \\
\hline $80-89$ & 52 & 57 & 109 \\
\hline $70-79$ & 40 & 47 & 87 \\
\hline $50-69$ & 7 & 16 & 23 \\
\hline TCTALS & 111 & 130 & 242 \\
\hline HEAAN & 81.3 & 80.0 & 80.4 \\
\hline
\end{tabular}

The distribution in Table 9 above fives the general averages for the Soptember to February. 1940 semester. It Includes 241 pup118. Genoral Averages for 9th grado puplls just ontering sonior hith school vere not inoluded as woll as tho avorages of 12 puplis who had transforred from out of state sohools.

The distribution for the boys, girls, and total group is all sewed to the left. The moan for the total group is 80.4 whilo the mode 1882.0 . The mean for the girls 1680.0 and the mode is 80.1 . The mean for the boys 1881.3 and the mode 18 82.0. Apparently the girlo' mean general averago $18 \mathrm{~s} 11$ htly bolow that for the boys and the girlo' distribution $10108 \mathrm{~s}$ highly skewed to the loft. Evidently these superior puplis aro dolne, work from 2 to 4 yoars bolow thoir mental ago lovel. They aro oertainly not working up to their capaolty. It is aurprialng 

to find those firls makin focror avorapo scholarship narks than tho bogs, avon thourh tho differanco is so siall.

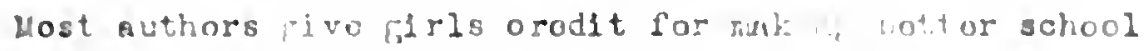

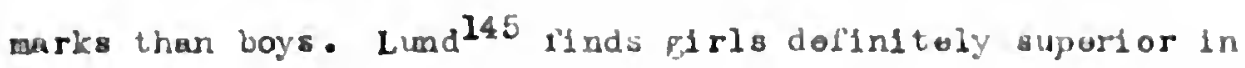

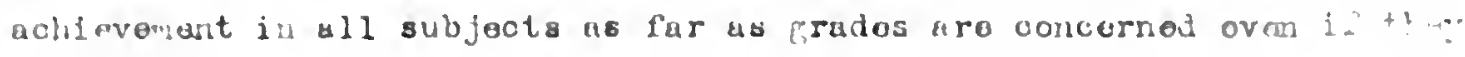
aro satchoc for iutolifperico. Book, Lohnon, und Futtorson 146 roport provounced difiortnco in scholarship marks in favor of the [irls. These reports are 1 lisutrative of the trond of rindings on the subject. Perhaps, whero superior puplis only are studied, the advantaro of the girls over bojs in schuol marks disappoers. Frobably there is a direot cannection botwoen this ard tho fast that tho achievenent ratios of the bors surpass those of tho girls. Certalniy If these boys work hardor, and have higher achiovenent ratiog, thoy are loss 11 kely to to surpassed in school marks by the irls. F'. Data an Conduct and Effort Biarks

Tables No. 10 and 11 show distribution of unsatisinctory conduct and offort marks for the pupils studied.

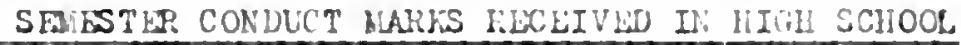

\section{rumber of}

Unsutisfactory IVISERT OF' P.JIIS

Sester Conduct

\begin{tabular}{cccc} 
Larks & BOY & GIRLE & IUTAL \\
\hline 0 & 108 & 125 & 233 \\
1 & 17 & $1 \%$ & 34 \\
2 or more & 18 & 12 & 30 \\
\cline { 2 - 4 } TOT ALS & 143 & 154 & 297 \\
Mbirs & .4 & .3 & .3
\end{tabular}

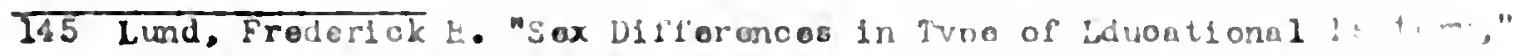

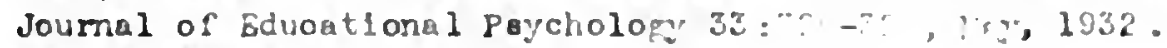

146 Yonroo, Waltor s. op.c1t. p. 154. 
TABLE NO. 11 - DISTKIBUIION OF HHE NULHEI OF UNSATISFACTORY 3E:ESTER EEFORT LARKS REXEIVED IN HIGIS SCHOOL

Number of

Unsentis faotory NURBIR OF PUPILS

Sowoster Irfort larks BOYS GIRIS $\operatorname{TOTN}$

0 118 134 252

1

$$
9
$$

12

21

2 or nore

$\operatorname{Iot} A$

$-1$

16

8

24

143

154

297

YEAN

.3

.2

.2

Tho vory great majority of tho puplls studiex have satisfeotory rks in conduct throughout the time thoy had spant bn ligh school. The distribution of oonduct marke. in pable 10 for the boyr, g-1s, and total group 18 quite derinftoly skowed to the ripht boosuse only 64 puplis of the 297 studied rocelved unsetisfuctory enerk in conduct while they wore in high sohool. It is interesting to note the aean number of uncatisfactory oonduct narke recoived by the boys (.4) 1 s greater than of ther tho moen number of umsnt1 sfactory marke rocelbod by the Eirls (.3) or the noen for tho total group (.3). It soems here that in the matter of oonduot marks, these puplis of supericr intellicence are rumninf, true to form, the boy beinf lose eatisfactory in conduct than disla.

When the frequenoy distribution for insatisfaotory scestor offort marics in Tublo 21 is studied, it 1 obsorvod that tho freat nafority (252) of the puplis had rooelved no unsatiofaoory semester offort marke thwoughout the tino they had spant in high sohool. 

whilo only 45 pupils had rooelved ono or nore unsatisfactory boster effort marks. Naturally, in the caso of tho boye, girlo, and total group, the distribution was highly skewed to the right. The mean number of unsatisfactory effort marks roogived by tho boys (..3) is -gain Ereater than tho moan numbor of unsatisfaotory eifort marko (.2) recelved by the glrls or by the total group (.2). Thesc indines on conduct and offort of boys and girls are in genoral agroesont with those already found. It is intoresting to noto that, al though tho boys' oanduct and effort 18 considorod by their tuachers to be lese eatisfactory than the girle', the boys are still able to make better mean scholarahip arerage and achlovenent tost soores than tho girls. These differences, howover, between the sexes are ail too small to Indiogte that any real difference oxists that could not be due to ohanoe.

\section{G. Data on Senosters Fallod.}

Table No. 12 shows a distribution of the cenosters ralled by the superlor pupils otudied whlle thoy wore attending high school.

TARLE 12 - DISTRIBUTION OF THE NUMUER OF SLIESTERS FAILED IN HIGH SCHOOL, SISPARATED FOY BOYS AYD GIRLS.

No. of

Senestere NULBER OF PUPILS

Fallod in iligh School Boys G1 r18 Total (iroup

0 128 148 276

1 or more 15 6 21

TOTALS 
The frequenoy dietrlbution of the number of enosters fallad by the pupila of superior lntelligenoe is hiphly skcwed to the right for boys, $\mathrm{g}^{1 \mathrm{r}} \mathbf{} \mathrm{s}$, and the total group. Only 21 of tho 297 pupilo et udl ad had fallod ono or moro mesters in high school. Thi 10 a rather smil poroentafo of sestor fallures for this particular group, but it may bo explained by the faot that hifh ochool pupilo who fall one or moro semesters very frequently drop out.

It would be intereating; to note how many superior pupilo who start high ochool drop out boouso of failure. Unfortunately, the data collected did not cover this apect of the problem. Afain it must be noted that more boys than girls failed one or wore semesters while in high school. while the moan number of fallures for the total group was only ol of one cenester falled in high sohool.

H. Date on Semestors Aooolerated

Table 13 shows the number of semesters these pupils of ouperior intelligence have akippod throughout thels attendarco at sohool fran the firet grede an.

TABLE 13 - DISTRIBUTION OP THE HUMBER OF SEULSTEIS SKIPPED TFROUGHOUT ATENDANCE IN ALL SCHOOLS, SEPARATED FOR BOYS NWD GIRLS.

lio. of Sertere NULBER OP PUPILS Ski ppod BOYS GIRLS TOTAL GROUP

0 68 74 142

1 25

42 67

2 33

32 65

8 or more 17

6 23

TOT A 

The froquenoy distribution for the number of someaters acoelerated or sklpped shows a canelderable numbor of puplia akipplne seneoters. This data ooverd the gradea sidpped throuphout the pupilo' attendarce at school from the pirst grade on.

Tho diatribution was again skeved to tho right for tho boys. girl6, and total group. 142 pupl 18 had not skipped any prader. wh110 155 had akipped one or more semesters during thel sohool oareor. The moan number of semesters skppod for tho total group was 2.1. The mean number of semesters skipped for the f1rls was 1.2. a trifle greater than the mean number of semestors okdppod for the boys $(1.0)$.

I. Sumary of Date on Aohi ovement for Superior Pupil..

Dats on worlevement test soores for the group indicates that the superior pupilo are oonsiderably above average for achievenent, that the boys exoel the Girls in sean achlevement teat soores.

The data on mental ages gives the boys a silght super-

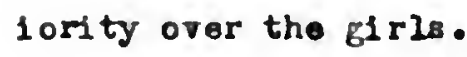

The data on I.Q'G gives the boys superiority over the Eirls in mean Otis Intelligenoe Quotients and the Henmon-Nolson Intelligence Quotients. The mean I. Q. for the total group on the Otis 1. 123.6 and on the Honmon-fielson 18126.6 .

Date on ahiovernent ratios pivo the boys deflnd to superiority over the firle und indloate that the nohiovement of both boys and firlo in high ochool subjocto 18 considerably lower than ad ght be expooted, using their intellifenoe sooros as moasures 

of promiso.

The data on Eonoral acholurship avorulat lniluate that

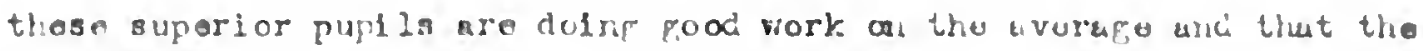
boys are doinf sllfhtly bottor then the firls.

The date on onduct and effort nerke indicato that tho puplis of superior intellígenco roosve relatively fow uncutisfactory oonduct end effort rarks in high sohool and that the boys receive more unsatisfactory marks in conduct and offurt than the c1rls.

Tho data on sonoters falled show that the boya rail

nore sanesters in high bohool than the girls, unt that ol ther a very small number of suporior puils fall semosters in hifh school or, is they do rall, thoy do not continue in high school.

Tho data on semesters accolarated in school show that the girls skippod more senesters tran boys throurhout theis school carcor, and that the average number of semesters skippod is just a triple over one iar the puplis studied.

There is nothing esperially starting about those data oxoept that wherever the boys are comparad with the girls, the firls suffer by comparison excopt in the natters of sanosters sisppod,

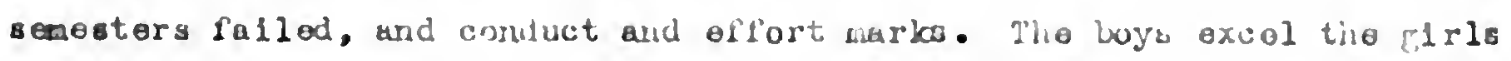

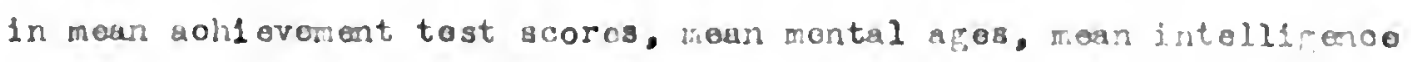
quotiants, moan ucilovenont rutlos, anl mon soholurship averuges. Thoo rosults are sucmarizod in Tablo 14 . 



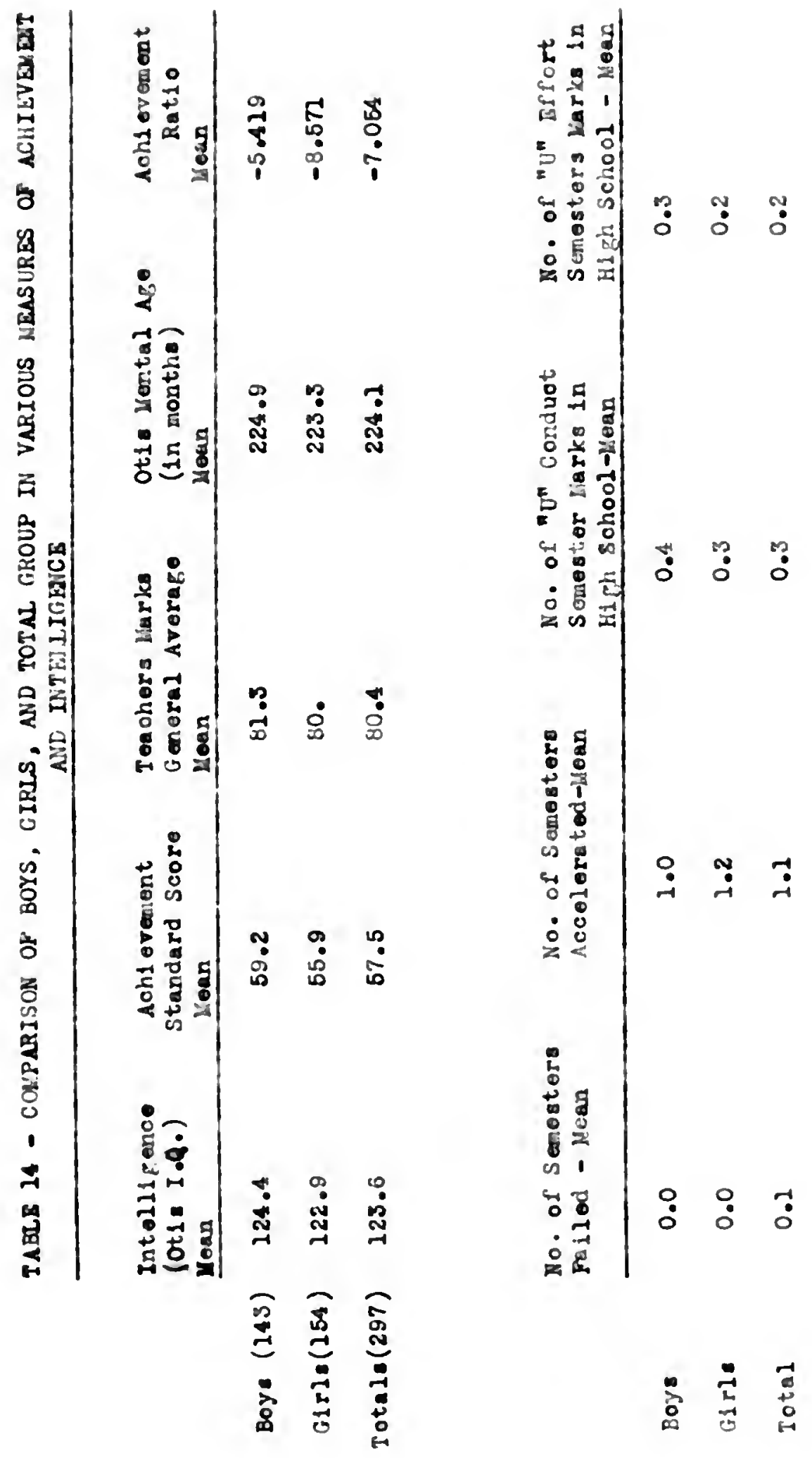




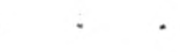


THE RELATION OF ACHIEVEIENT RATIO TO FERSOLALITY TEST SCORES

A. Tho Relation of Scores on tho "Washburno Social-Adjustmont Invontory" to Aohiovomont Ratio

1. Truthfulness to Aohievement Ratio

2. Happiness to Achievement Retio

3. Alienation to Aohiovement Patio

4. Sympathy to Aohievoment Ratio

5. Purpose to Achiovement Ratio

6. Impulse-Judgment to Achievement Ratio

7. Control to Achievoment Patio

8. Teshburne Total Scoros to Aohievement Ratio

B. The Relation of Scores on the "Link Inventory of Activitios and Interests" to Aohievement Ratio

1. Sooinl Initiative to Achiovement Ratio

2. Self-Determination to Achievoment Ratio

3. Eoonomio Self-detormination to Achievernent Ratio

4. Adjustmont to Opposite Sex to Achievement Patio

5. Overell Personality Cuotient to Achievernont Ratio

6. Sumnary

1. Results related to previous studies on iersonality 
CHALTER V.

THE RELATION OF ACHIEVEYENT RATIO TO I.EKGOHALITY TEST SCORES

Two personality tost batteries were administerod to every mull participating in the study. The ecores obtninod on these forsonelity tests woro usod as a basis for comparine forsonality with aohievemont ratio.

The Relation of Scores on tho "Washurno Soclal-Adjustment Invontory" to Achievement Rutio.

The Whourne Soolel-Adjustment Inventory, Thaspic edition, is made up of 7 subtests. The relation of tho achievomont ratios of tho boys, Girls and total group with the personellty scores on these 7 subtests and the "ashburne total scoro was folmd. Tho Relation of Achioveinent Fatio to Truthfulness

A screoning test of truthrulness wis given to all tho pupils, composed of questions designed to reveal oarolessness or misrepresentation in replios. These questions scattered throughout the Washburne Inventory were of suoh a nature that the apparently desirable answers Indloated inaoouray or lying. The frequonoy table 15 and graph. Figure 1, below oontein and 1llustrete those data.

The great jority of the oasos in this study made rather low soores on the truthfulness subtest and, oonsequantly, rated rather hifh for trutheulnoss. The distribution alpoared to be closo to the normal, boing a bit skewed toward the right by the proponderance of low acores Indionting oxcollent adjustmont as far as truthrulnoss was concorned. 



\section{TABLE 15}

[13tribution Stowlng the Peletion of Moplevarant

Facloe to insliburno iruthrulnosa veoro:

iivin tho Ueene for ine and is rlo jog amtoly

\section{TRUTHEULHESS SCORES}

Achlevemont

Ratio $0-4 \quad 5-9 \quad 10-14 \quad 15-19 \quad 20-24 \quad 25-29 \quad 30-34 \quad 35-74 \quad$ Totals

10 to $19 \quad 1$

1

2

1 to 0

$7 \quad 8$

13

3

7

4

6

1

49

-9 to 0

$21 \quad 25$

$33 \quad 23$

19

10

5

15

149

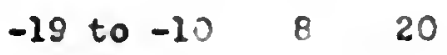

$18 \quad 13$

5

2

7

10

88

-29 to $-20 \quad 1$

23

1

2

1

1

11

-39 to -30

111

3

\begin{tabular}{|c|c|c|c|c|c|c|c|c|c|c|}
\hline$x$ & & 38 & 51 & 67 & 43 & 33 & 19 & 19 & 27 & 297 \\
\hline $\mathbf{x}$ & & -5 & -7 & -6 & -9 & -6 & -3 & -7 & -9 & -7 \\
\hline Boys & 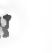 & 14 & 24 & 39 & 17 & 15 & 9 & 10 & 15 & 145 \\
\hline 4 & 4 & -2 & -6 & -5 & -7 & -5 & -4 & -6 & -6 & -5 \\
\hline Girls & $\mathbb{N}$ & 24 & 27 & 28 & 26 & 18 & 10 & 9 & 12 & 154 \\
\hline & 1 & -7 & -6 & -7 & -11 & -7 & -11 & -7 & -12 & -9 \\
\hline
\end{tabular}

$F($ total iroup $)=10.53: p=.01$ 



Tho "g" tost was $118 \mathrm{~d}$, and a value of 10.531 wno obtuinod for

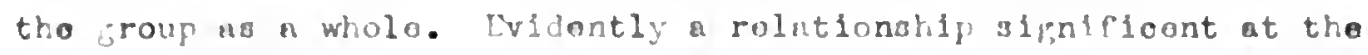
ono for cont lovol oxists botwoen nchiovonont ratio and truthelness scores of tho superlor puplis studied. Wion the eraghio rolationship as shown in Fljuro 1 is studiod. It appoers that the rolationship is positivo but rather small.

The fuplis makin the lowost sonres, indicatine they are woll adjustod for tmuthrulnosa, had the hichost moan achievemont ratios. the poorly adjustod or untruthrul pupils had the lowest mean achievement ratios.

- is relationship hold with very little variation for both boys and sirls.

The main chareotoristic of this graph showing the relationship betweon truthfulness scoros and achiovoment ratios is perhaps its fluctuation around the mean. This characteristio is probably as important as tho faot that there is a significant positive relationshlp between achievement rntio and truthrulness.

Th.ls significant assoolation of truthrulness with high achievenent ratio may be accounted for in soveral ways. The pupil who is more nearly achleving up to his oapacity is more likely to bo doing satisfactory work and consequently will have loss occasion to be untrutheul in order to make a good impression. On the other hand, the habit or trait of untruthfulness may heve boon developod by some fupils to such an oxtent that it w1II have a dotrimontal offoot on tho toudior's

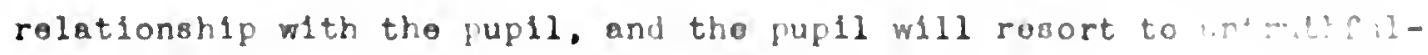

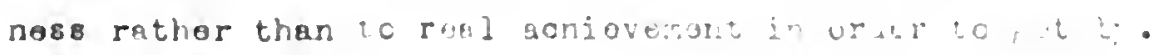



Tho Polation of Achiovement Ratio to Happlnoss

On the happlnesa aubtest of the ivashurne Soolal-Adjuatment Inventory, a low score Inds oates excollent adjustment, whlle a high score indloates poor adjustment for this porsonality tralt. This is true for the remain!rg subtests in this inventory.

The frequency Tablo 16 and the praphio Figurc 2 contain asd 11lustrate the date colleoted on this relatianship botwoon aohiovomont ratio and happiness.

223 puplls of the group recolved happiness scores indicating normal or botter adjustment. 49 oases are rated low normal in adjustment for the trait, whlo only 25 are borderline or maladjusted.

The distribution of Washburno happizess scores is definitely skewed to the rlght because of tho groat number of casos falling In the low soore categories.

The $F$ tost oalculated for the total group is 7.56 which is slensficant at the one per oont lovel.

Apparomtly a relationship that is signifloant oxiats botwoen achlevement ratio and washburno happiness aubtest scorse. Reforenoe to the graph showing tho relationship botween achievement ratio and Toshburne happiness soores in Flgure 2 ind oates that this alpniflcant rolationshlp 16 nogetivo.

When the low normal group is compared with the poorly adfuted pupile for this trait. a notiosable differenoe between these two Froups is discovered. The puplla who have low nomal happiness acorea make achlovocent ratios below the mon ior the group. whilo the puplis 

Distribution Showing the Relation of Aol.jovement Rat1os to Nashourno Happlnoss Scores 'indup the Hanns for Boys and jirls Separately.

TASHBURNE HAPY IMESS SCORES

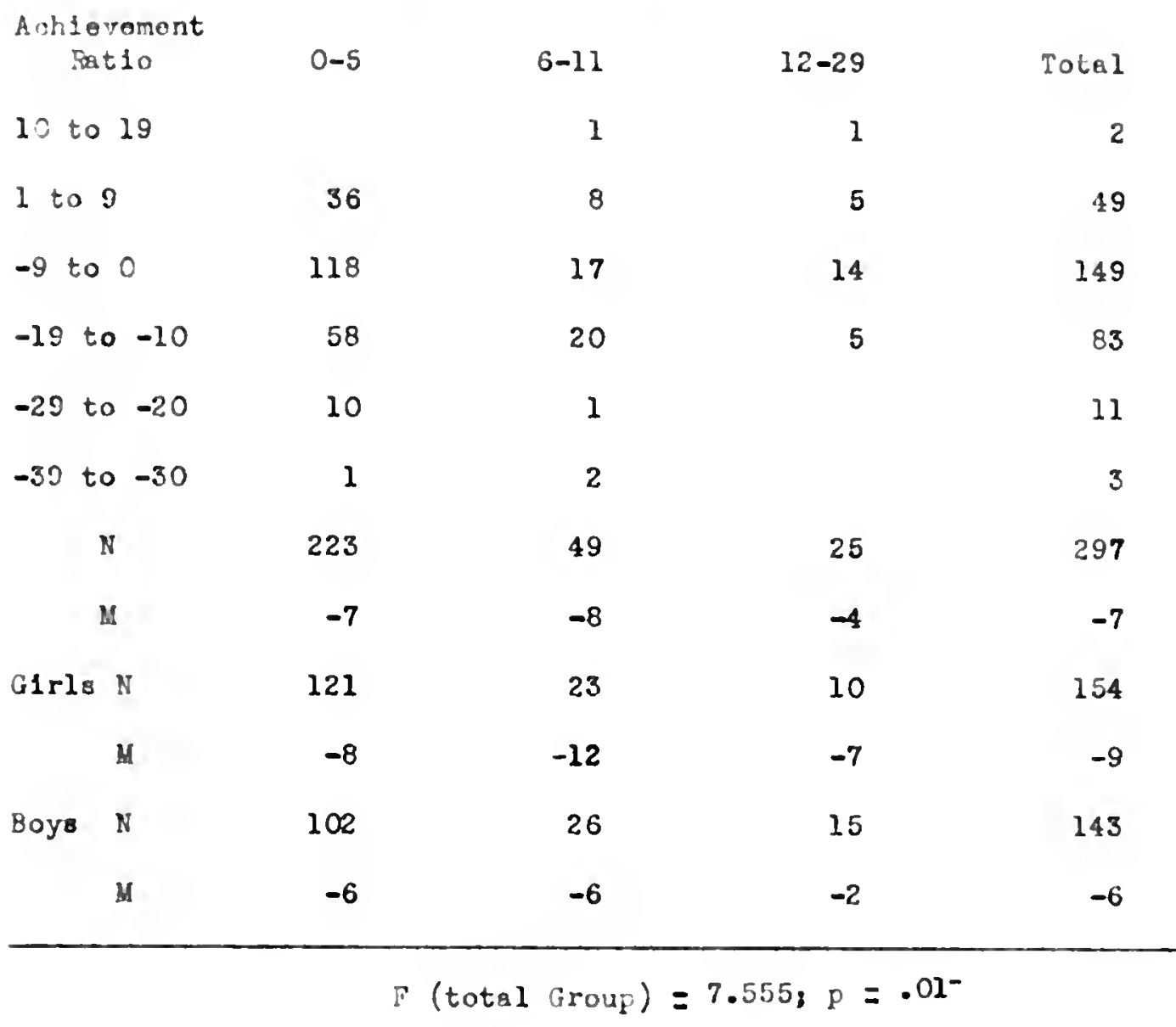




who are borderline and maladjusted make achlovemont ratlos doflnitoly above the monn. The low normal oases dropped considorably in moen achievorant ratio, whilo the poorly adjusted osser axcislod ull athers in rean aohs ovement ratio.

In achlovement ratio tho woll adjusted pupl is rank slichtly ahead of the pupils who are low normal in adjustment for happlness, but definitely bolow those pupils who are maladjusted as indioated by this happiness subtost.

The serio relationship botween happiness scores und aohlovement ratio holds for both boys and girla when thoy are conaldered separate1y. For boys and girls as for the group as a whole, the normal and poorly adjusted puplis axoel the low normal adjustment oases in mean achievement ratio.

This sipniflcent nogative, although slight, relationship botweon achlevement rat10 and happiness soores may be acoounted for in several ways.

The ract that thare are only 25 borderline and maladjisted cases may aocount for thls doviation frox the gonoral trend. or it may be that puplls who are vory unhappy opend a groator proportion of thoir time aray frcon thelr fellowa in ocmparative secluaion and thus find moro time to study and advance soholestioally. It may bo that up to a cortain point, the more unhappy you are, the loso your aohsevonent ratio will be. bocause of a poor adfustment to your surroundings, but beyand this point, an inorease in unhappinoss may onuse you to epond more tio in individual aotivities not asooolated with a social group, whioh in turn may result in incrossed aohlovernent ratio. 

The Relation of Achlorement Ratio to Allonation

Allonation 1 s desoribed by Washbume148 as including a sense of soolal mombersip. simllarity, pyohologionl security, and omotional atablifty in sooial situatione. A low acore on the alienation oub teat of the Washburn. Inventory indicates sat isfaotory oolal and enotional adjustment a rerealed in a sense of non-alienation.

Tablo 17 and F1 gure 3 contain and 1 llustrate tho cato pathered on this varlable. Of tho 297 pupils studied, 75 are poorly adjusted as revealed in a poor allenation score. The remalning 222 puplla have normal or abote adjustononts, acoording to the standards prorlously set up by Washburno. 148

The $F$ tost for the total group showed that there is a rolationship botween achievement ratio and allemation, significant at the one por cent level. When the graphic relationship botween achiercent ratio and allenation in Figuro 3 is studiod, it la observed that this relationship is nogative. Aa the aolioremont ratio increacea, the score on the alienation subtest increases, indioating an increased laok of adjuatmont as tho achlevenent ratio increases.

There 18 considerable fluctuation in the curve for boys and girls, but tho curve for the total group maintains a oonalstant upward slope. When the relationship betweon the aohlevement ratios for

148 Washburne. John N. Washburno Soc1al Adjastment Inventory (Thaspic Edition) Lanuel for Interproting, World book Co.. Yonkers-on-IIudson, Now York, 1940. p. 4 .

149 Ibid. p. 4. 

the boys and allemation 15 considored, it is noticed thet the ourvo rises unlformly unt1 it ronclos tho $31-40$ interval. It then

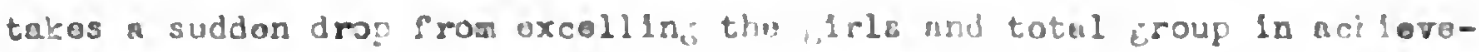
ront ret10 to boin oxoolled by tho irle and totul froug. Pron roro on, it rises slowly but standiy. It ruet bo ronombored thet there aro only 9 oasos in tho 31-40 intorual and that this io quito poobibly the -oason for this rluctuation. Mon the curve for tho relatlonatil letwoon the -1rls' schlorement ratios and alonetion In tho figure 3 is studied, tho oprosito trond ie notad. Tho ourve for tho achlovoment ratios of tho pirls 18 unforaly downed unt1l tha 31-40 interval for allonation scoros is roachod, whan it takos a buddon loc an? eron tilis point on falie slowly to the end of tho distribution. Thio rluatuation 18 due to only e casos. Tho sluctuation around the $31-40$ intervel in tho currae for boye and firls may bo discountod bocauso of the sall numbor of cesos 10 this particulas lntorval as showa in tho frequency tablo 17.

Tho unl:om negntive rolationship botroen achleresent rutio and adjustwont co: aliomtion al ht bo conountod for is this why. Eocauso Ellanation conalste of suah thinja es soolal romborshif. pryoholoilcal soourity, and amotional stakility in ooolal altuetione, e pupli lackine In this constellation of tralts way tond to bo noro of tho introvert. Individualistic tro and lose of a cacial bolib; and, ooneoquantly, havo more tine for suoh individual labore as sohool work. Converely, thoee social, ccauro, etcblo puyllo probauly dovoto moro tice to out of ochool sotivitlos and lose timo to sotual study and this would account for thols lowor achlovencint ratios. 

TATIE 17

Distribution Showing the fuslntion of Aohiovament

Futios to inshburno Midanation Scores Clving.

the sinans for oys and Cislo Sopuratoly.

\section{WASTEURVE ALLMTATION SCORTS}

Aohievament Ratio

$0-10 \quad 11-20$

$21-30 \quad 31-40$

41-90 Total

10 to 19

1

1

2

1 to 9

20

13

6

4

6

49

-9 to 0

65

47

13

12

149

-19 to -10

44

22

7

6

83

-29 to -20

6

1

11

-39 to -30

1

3

1

1

$$
3
$$

$N$

136

86

34

17

24

297

if

$-8$

$-7$

$-6$

$-6$

$-4$

$-7$

G1rls N

80

45

14

8

7

154

is

$-9$

$-9$

$-11$

$-4$

$-6$

$-9$

Boys II

56

41

20

17

143

$u$

$-7 \quad-5$

$-3$

$-8$

$-4 \quad-6$

$F($ total group $)=6.247 ; \mathrm{p}=.01-$ 

. 


The Rolation of Aohiovumant Ratio to Sympathy

Tho torn, sympathy, is dofined as "oympathotio, ompathotio, non-negative responsiveness to people."150

A low soore on the Washburne 150 Social-Adjlistmont Inventory sympathy subtest indioates a satisfactory social and emotional adjistment as roplected in sympathy.

Table 12 and Fygre 4 oontain and 11 lustrate tho data on this variable. Aocorcing to the standards set up by Washburne, tize great majority (251) of the pupila recolve soores indiating that they are low sorulal or better as far as sympathy is conoerned. The remining 46 casos are below low nomal in adjuetment on this trait.

The $E$ test for the total group gave an $F$ of 13.38, showing that there is a signilicant relationship between Washburne sympathy soores and aohlevenont ratio for this group of 297 pup1 1s. When the graphio rolationship is reforrod to. It is notioed that the relationshlp is negative, that 18, the highor the achievement ratio, the poorer the adjustment for sympathy. The ourves for boye, G1rls, and total group are oharacterized by oonsiderable rluotuation.

The general trend for the total group is rather consiatant, exoopt at the end of the ourve, where the maladjusted puplis show a olight drop in achievoment ratio. The surve for the boys sow oonsiderable fluotuation, atarting out 6 ahievenont ratio points above the ourvo for the total group and 7 abote the curve for the girls. The ourve then continues to fall uniformly until it reaches the 16-19 interval whero it takos a 

sudder r180, and from the point on drops alowly to tho ond of tho diatribution. The ourve for the girls fluotuates oonalderably. It is up and down throughout the oourse of the graph, indlanting a rather inoansistent negative relationship botwom achlovonont rutio und sympethy 3 cores for the girla.

As oan bo noted by reforring to Table 18, the firls as a group aro sansiderably mare sympathetio than the boys. The oases for the boys tand to fall tawserd the ungypathet1o and of the ourve, whilo the onses for girls tend to oluster toward the sympathetio end of the curve.

This slight although significant negativo relationship between achlevement ratio and sympathy sooros may bo acoounted for in this way. The people who are likely to have high achlevement ratio soores are likely to be working closer to their capacitiea, are leas 11 kely to take timo enough to exhibit sympathetio tendenoies toward their canpanionss and, as a consequenco, people with highor ahlovement rat1 os $\$ 111$ have lower sympathy scorea.

Girls are as a group gonerally moro tender-hearted than boys and mentally superior firls appear to be no exception. Porhaps this oharacteristio of firls is responolble for the negative relationship oxi et ing betwoan aympathy and achioverant rat1o.

The Relation of Ach! svemont Ratio to Iurposo

A low soore on the Washburne purpose subtest ind latos setisfaotory adjuetiont as rovioalod in a sense of purpose, 1.0. "desire dofinitely dirocted toard a goal involving plan, ovaluation, solootion, and offort."16l This subtest was given to 297 pup1lo. Tablo 19 and Flgure 5 contuln and 

TABLE 18

Distribution Showing tho Rolation of Aohiovomont Rat1os to Washburno Sympathy Scores Giving tho Moans for Boys and Girlo Soparatoly

TASIBURIE SYMPATHY SCORES

Achievement Rat1o $0-3 \quad 4-7 \quad 8-11 \quad 12-15 \quad 16-19 \quad 20-43 \quad$ Totals

10 to 19 1

1 to 9

5

9

6

10

10

1

2

-9 to 0

24

35

25

24

18

9

49

-19 to -10

18

13

24

11

6

11

-29 to -20

5

3

1

2

11

-39 to -30

12

2

$54 \quad 59$

56

48

35

46

297

u

$\begin{array}{ll}-9 & -7\end{array}$

$-8$

$-6$

$-4$

$-6$

$-7$

Girlo N

$50 \quad 38$

29

20

10

154

$\boldsymbol{y}$

$\begin{array}{lll}-10 & -7 & -10\end{array}$

$-6$

$-8$

$-8$

$-9$

Boys X

$4 \quad 21 \quad 26$

28

28

36

143

M

$-3 \quad-6$

$-6$

$-7$

$-4$

$-5$

$-5$ 



11lustrate the data oollooted on this viriablo.

An oxanination of the duto in Iable 19 on the totul group shor that 218 pup11s. $116 \mathrm{~g} 1 \mathrm{rlg}$ and 102 boys, made sooros ind oating noral or bottor adjustonent for this porsonility trait, nooording to the nores sot up by Washturne. The remaining 79 borderline or maladjugted pup1le includes 38 girls and 41 boys.

The distribution of furpjoe soores olosely follows that for a nomal population, again belng a triflo skered toward the lower end of the distribution. The mean anu the mode fall in the camo 1aterral, 49 to 54 , whi oh 15 normal aooording to Wastiburio.

The E tost for significance for the total broup jieldod e value of 11.974 ohloli is signifleont at the ono per cont level. There as a 59 chances in 100 that a rolutioushlp exists botwoen achlevemont ratio and purpose subtest soores for these pup1ls. Then the graph1o relationship as shown in Fikure 5 is studied. It appoars that the rolationship 18 linoar, positivo and small. Iho chiof oharactoristio of the graphio 11luatration of the relabionship is its fluotuation. No unifora trend 18 ooldert. As might be expectod, the fluctualion $1 \mathrm{~s}$ greatest at tho onds of the curve whore the number of cases in each catogory is smallost. tho pup1ls making comparatively low scores, Indloathug exoolient adjustment, on the pur 080 subtest in the $27-33$ interval havo the highest moan achioverent ratios, and the pupllu making comparatively high soores in the 69-75 Interval an the purpose subtest make the lowest moun aoliserumet rat1os for the total group.

Apparently, good adjustment a measurad by the Nashbura Purpose subtost is positivoly rolated to hich achiovement ratio for puplis of suporior intoll1gonoc. 


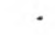


When the rolationship botwoen the ohlovement ratios and purpose soores 1a studied of the boys only. It is observed that the fluotuation Is $108 \mathrm{~s}$ and the positive relationshlp is apporently increased.

When the rolationship for the girlo only is studied, the fluctuation is observed to inorease and the positive relationohip soenc to disappear.

The positive relation botwoen eohievenont ratio and puoposo as Indicated by the Washbume test may be eooounted for in sereral rays. First it must be remenbered that the relationship 18 small and that there 18 a chanoe in a hundred that it does not exist at all. Granted, however, that a relationshlp of small degree exists botwaen aohievenent ratio and purpose, it may be that high achlevenent ratios are emoouraged by proper adjustment for purpose, as dofined by Nashburne.

Quite probably a deflnite puspose serves as an incentive to superior pupils to higher schievenent in sahool. This is more likely to be true if the pupil's purpose is as soolated with furthering his eduation. This, too, would aocount for the differences between the girls and boys. The purposes of the boys are pose1bly sore dependent on suooess in sohool then those of the girls and oonsequently, this would oooount for the higher relation botreen sohievement ratio and purpose soores of the boys. The purposos of girls may not be alosely dopendent an sohool sucooss and this would acoount for the diminished relation betwoen the aohierenent ratios and purpose scores of the girle.

It may be that both high sohlovement rntios and good purpose adjustments are caused by a third faotor or proup of factors. In the opinion of 
the author, the second hypothosis is true ar oxonlont adjugtmont for purpose helpe a fupll. Farticularly a bey of guparior intelificonco. make a high nchievonont reatio.

The Rolntion of Aohiovoment inlio to Injulso-Jui mone

A low imulse-judgment sooro indicutos satiafuotory ndjustment as far us inpulsu-judiment is concorned. This torm may bo dofined us "the ability to jufge wail butwoon conflieting impulas. so that artisfactions which aro recognized as gruter, but nore renote or moro difficult, are not discounted in pavor of ousier or moro immediato but obviously lesser satisiructions." 152

The r requenoy Table 20 and Fiburo 6 contain and 11 lus.t,rate the dete collected on this vuriable. The froqueney distribution of Tashburne Inpulse-Judgment scoros shown in Table 20 is hiohly skorod to the right as are the distributions of the boys and birls.

259 oases (135 girls and 124 boys) have normal or better adjustments for impulse-judgmont acoording to the standards sot up by Washburne. Only 38 sases are border line or maladjustod for this trait. 19 are girls and 19 aro boys.

The f test for this variable for the total group yiolded a result of 6.689, which is sieniflcant at the ono fer cant lovol, indicetine trat a relntionshif exists vetween achiovenont ratio and Nashburne impulsojud Emont sooros.

Whan the eraphio rolotionship in figuro 6 is studiod, it is obsorrad that the curvo for the total group is a vory plat boll-shapod ourve, with the groat majority of the oases on tho loft side of tho curvo. The indiontion is that tho relationship butween the variablo and achicvomont 



\section{TALLE 19}

Distribution Showing tho Rolation of Aohiovemont

Ratios to thshburno l'urposo Scoros living tho Keans for Roys and Girlo Soparatoly.

MASHBURNE PURF OSE SCORES

Aohlevenent Ratio 0-26 27-33 34-40 41-47 48-54 55-0்1 62-ن் $69-75 \quad 76-96$ Total 10 to 19 1 1

1 to 9

46

7

7

7

4

5

3

$6 \quad 49$

-9 to 0

19

22

22

32

21

14

$8 \quad 149$

-19 to -10

6

17

6

15

8

10

$7 \quad 83$

-29 to -20

13

3

3

1

11

-39 to -30

1

1

3

\begin{tabular}{|c|c|c|c|c|c|c|c|c|c|c|c|}
\hline \multicolumn{2}{|l|}{ N } & 19 & 31 & 48 & 41 & 49 & 44 & 27 & 17 & 21 & 297 \\
\hline \multicolumn{2}{|c|}{$u$} & -8 & -4 & -8 & -7 & -7 & -8 & -6 & -10 & -5 & -7 \\
\hline \multirow[t]{2}{*}{ GIrls } & $\mathbb{N}$ & 7 & 16 & 23 & 24 & 28 & 26 & 9 & 10 & 11 & 154 \\
\hline & $u$ & -14 & -6 & -11 & -8 & -7 & -11 & -5 & -13 & -6 & -9 \\
\hline \multirow[t]{2}{*}{ Boys } & $N$ & 12 & 15 & 25 & 17 & 21 & 18 & 18 & 7 & 10 & 143 \\
\hline & $\mathbf{y}$ & -4 & -2 & -6 & -6 & -6 & -8 & -7 & -6 & -5 & -6 \\
\hline
\end{tabular}

$F($ totel group $)=11.974 ; \mathrm{p}=.01-$ 


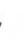




ratio is rathor nogative. 1.o. the botter tho adjustmont for liashburne impulse-judgmont, the lower tho achiovement ratio. The highost moan achlevement ratio for both the girls and total group oocurs at the intermodinte 8 to 9 intorval on the washburno impulse-judgmont scores. Soores in this interval on the Washburno impulse-judgment subtost are considered to be an indioation of low normal adjustment for this perticular trait. No uniform trend is noticosble in the graphio rolations show in Figure 6. Fluctuation seems to be tho dominant charaotoristio of the 3 line graphs shown in this rigure.

Tho boys seom to differ from the girls and tho total group as vell, In that the relationship botweon Washburno impulse-judgmont soores and ahievement ratio appoers to be slightly positive. The highest achievement ratios for the boys oocur at the 2 to 3 interval for the Washburne impulse-judgment soores, and the lowest moan achievemont rat1o for the boys ooours at the opposite ond of the ourve at the 12 to 25 interval. This general positive trend on the part of the boys is counteractod by the faot that aonsiderable numbers of oases fall in the first intorval, and the trond from the first to the seoond interval is dooidedly nogativo.

Although there is a significant rolationship existing botwoen Washburno impulse-judgmont scores and achiovement ratios, it is evident by study of the graphio rolationshipe that these rolationships are rather slight in degree.

These relationships may be acoounted for in a number of ways. Twentyone pup1la having low evorago impulse fudgmont adjustments have littlo ability to judgo betwnem conrlictinf, impulses and ofton soleot satisfaotions wioh aro lessor vul more imediato. This porsonnlity weakness is assoclated with ligh achiovomont retlo and is somewhat difficult to 



\section{TABLE 20}

Distribution Showlin the Rolntion of Achiovomant Ratloe to Tachburne Implse Judzment icores Givine the Heane for Boys and Girls Soyarntoly

MASHBURNE IUSULSE JMGIRENT SCORES

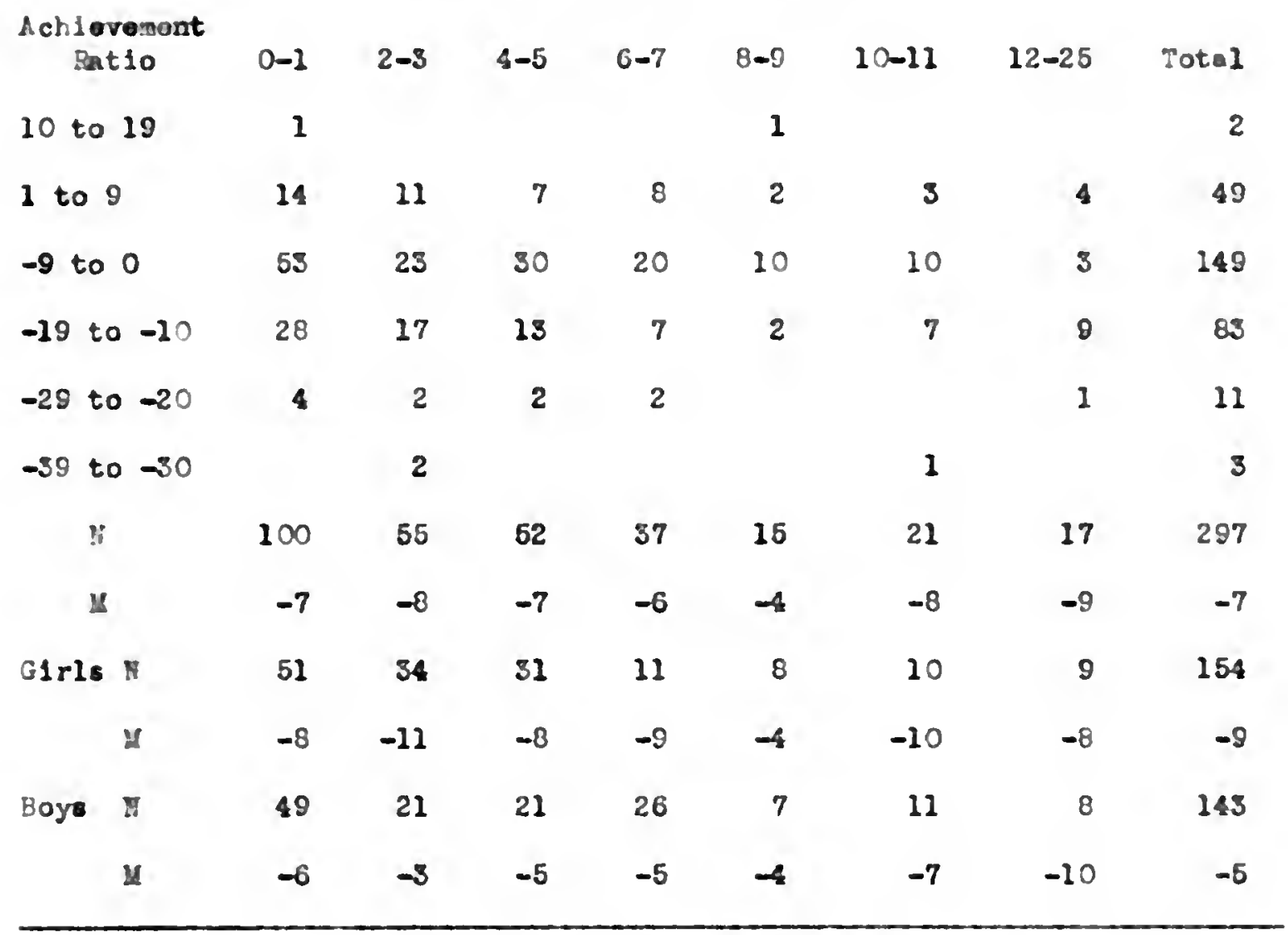

$F($ total Eroup $)=6.689, p=.01-$ 




$$
\text { - }
$$


aocount for. Porhips axcollunco in sohvol Lchionvulent may rosult fran just mah traits. Ioworer, when tho adjustrant ion impulso juderent bocomas coctronely poor tho achiovantont rutlo drops aharply. This may bo tho result of odxyleto Innility to soloct solool tasks as dosirablo satisfrotiono to bo attained.

Tho boye differ fros tho Eirls in that those boys showing avorage adjustanent drop in achior erront ratio whilo tho firls riso in mean wohiovogant ratio. Possibly tints is a ohance fluotuntion. Porhups it is a fundamental difforaco jotwoes boys asul firls of superi or latelliganae. At and rate, the ganoral nogativo rolationship wisting botwoon impulso fudgmont and wohicrowant ratio is the inportant sinding.

Tho Folation of Achiovamont Rat1o to Control

A Low score on the control subtest of the rashburno S-A Inventory indlcatos satisfiactory adjustinent as shovm in a sense of "self-control, self-regulation, and ability to make and axecuto plans." 153 Table 21 and Figuro 7 glvo the data collected on this variablo.

By reforring to tho frequency diatribution of the control subtest scores in Table 2l, ono can see that the groat najority of tho cases, 201, havo sooros undor 24 which, acoording to Washburno, Indicato Ior noraul or bottor adjustment for ocontrol. Of theso 261 cases 134 are birls and 127 ure boys louving a total of 36 pupils, 20 girls and 16 boys who mado sooros indicating raladfustment for control. As a result the distributions of control Boores aro akowad to the right for tho boys, girls and total proup - whoro the cases pilo up at the lowost tatervals. 

The fost yields a valuo of 6.002 for the total eroup which 10 Elgnifioant the tho ono por aent lovel. Thare are more than 99 ohnncos In 100 that a rolationship oxists botwoon tha achiovamont meios and the oontrol scores of those puplls of suporior intallicenco.

The eraph in Figure 7 for the total group indicates that the group of 102 pupils having the lowest oontrol scorer, indicnting bost adfustmont, have the highest moan achievement ratio. whllo the eroup of 101 puplls having the next lowest moan control score have the lowest mean achlovement ratio; and from this point on the ourve gradually rises. The relationship existing betwoon oontrol soores and achiovomont ratios $18 \varepsilon$ positive linear relationship throw off porhaps by a relatively small number of oaser in the intorvals at the maladjusted ond of the control distribution, or the distribution 18 curvilinear of the invertod bell type, possibly skowed to the right.

It 18 interesting to noto that this noticeablo drop in moan nohievement ratio at the $\varepsilon \theta c o n d$ interval in the control scores distribution ooours in both the boy. "nd girls'distribution as well as for tho total eroup. The drop in achievoment ratio at this socond intorval is moro notlceable for the boys than it 1 for olthor tho firls or the total group.

Judging from theso data a normal adjustment on the control subtest is moro olosely assoolated with a low nohlovement ratio than is olthor a good or poor adfustment.

This assoolation of low a ohiovoment mt10 with nomal ndfustmont for control may havo soveral oxplanationa. 

Thero are only 94 ones in the poor adjustmont ond of the control distributinn, and this rolatively amallor numbor of onsos no comprod to 203 onses in the bottor adjustment ond of tho distribution may bo indionting on assoolation betwoon poor adjustmont control soorno and high achiovomont ratios which doos not oxist. Tho rolationohip botwarn oontrol adjustment and aohievoment ratio may bo positivo throughout; 1.e., the battor the control adjustmont the bettor the achiavement ratio. Then again it may bo that high achlevement ratio is assooiated with both good and poor control adjustment, but for two different ressons. Perhaps a well adjusted pup1l, well adjusted for control, would have a natural advantage in progressing in school and so make a corrospondingly higher achievemont ratio. On the other hand poor adjustment for control may have a compensating advantage by increasing tho I hil's aclideverent ratio through reducing his soolal adjustment cutting him off to a cortain degreo from his assoolation with his follows and incrosing his attention to such things as school progross, which require little association with others $8001011 \mathrm{~s}$

Even though the $F$ tost indicates a signifioent relationship betwoen achievement ratio and control adjustment oxists, it may be prosont only to slight degreo. Tils relationship may be onused by olther of the variablos or by a third variable offeoting both. The Rolation of Achievement Patio to Washburno Total Sooros

The rishburno total soore is a composite sooro mado uf of the ton? of all of the subtest soores. It is a moasure of the total social adjustmont of the individual tested. Tho rolation of inabhurne total sooros to achloroment ratio may bo considerod a oumary of tho rolationships botwoen tho varlous subtost scores and achiovomont rntio. 


\section{.}




\section{-7 L.E. 21}

Distribution Showin tho olation of hol faverent

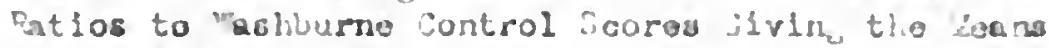
for noys and irle Sageratoly.

CASHRURNE COUTROL SCOHES

Achievinont

$$
3 a \pm 10
$$

$$
0-7
$$

$$
3-15
$$$$
16-25
$$

$21-71$

Totul

10 to 19

1

1

2

1 to $?$

22

10

11

6

49

-9 to 0

51

51

27

20

149

-19 to -10

27

32

16

8

83

-29 to -20

2

7

2

1

11

-30 to -50

1

1

1

3

N

102

101

58

36

297

$x$

$-6^{2}$

$-8$

$-7$

$-7$

$-7$

G1rle प

50

54

30

20

154

u

$-8$

$-9$

$-9$

$-8$

$-9$

Boys N

52

47

28

- 16

143

u

$-4$

$-8$

$-4$

$-6$

$-6$

$I$ (total group $)=6.002 ; p=.01-$ 


- 
Table 22, giving tho distributian showling the relation of achlovewant ratios to Washourne total soorea, shows clearly that the diatribution is skew a triflo to the right bocause of the piling up of scores toward the bettor adjustment end of the soore. The Washbume tast is set up so that a soore of 100 indicatos a normal persomality adjustment. For the 297 pupils tested, 34 are dofinttely suparior in their adjustment as measured by the Washburne S-A Inventory, 85 are above normal in adjustment. 76 oeses fall in the lower half of the nornal group. 55 are definitely low normal in adjustment, 67 are bordorline oases, and oaly 10 are defintely maladjusted.

Table 22 shows that the distribution for the girls 18 even more highly skewed to the right than that for the boys, whilo the distribution for the boys more olosely approaches the normal. Apparently, as negsured by the Fashburne S-A Inventory, the girlo as a group are better adjusted than the boys.

The $F$ test for varlance yields a value of 9.762 , whi oh 1a significant at the one per oent lovel. There is 1038 then one ohance in a hundred that thero is no 81 paflcant relationshlp between achierement ratio and Fashburne total S-A Inventory scoros.

Reference to figure 8 indicates that this relationship is of the flat inverted bell type. The pupila who save low total soores on the Fashburne S-A Inventory, indiating exoeliont soolal adjustment, and the pupils who have hlgh total scores on tho Washburne S-A Inventory. Indicating that their soolal adjustwemt is very poor, both exoel the group who have intermediato Fiashurne total soores. Indicating that they have an intormediate eoclal adjuetment. The ourve showing the relation of achievant 



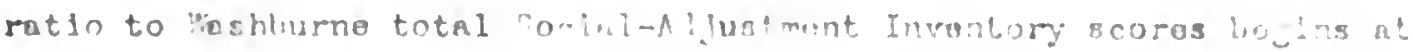

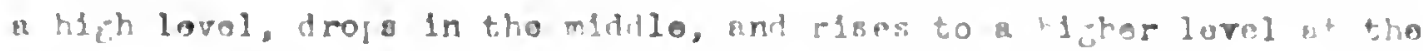

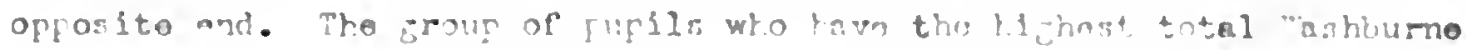
scoros and consuguently the prorost "abliurne anclal n! gustnon" excol all othere in monn achiovomont mtic, 1ncluding, those puplls who shov"

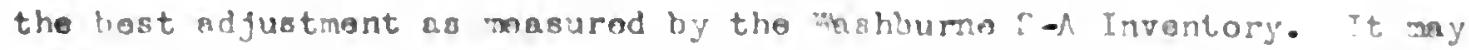
bo asoumod, thorofore, that high achlorement ratio is gosoointor with both oxcellont ndjustmont and poor apjustmont as nus:urgd by th:s inshbumo Social-Adjustment Invontorg; but, of tho two, tho hichor uctiavomont ratio in more closoly assoolated w1t! the poor aljustmeat. Low achlovomont metio is apporently associnted ifth intormadiato or noral adfustront $n$ s noecured by the ripshourno $3-A$ Inventory. with 1 ittlo or no varistion, this gituetion holds true for both boys and jils as woll as for the total group of pupils stidied.

lorhape thls slenifjcant relntionship botween vishburn S-i. Irventory total sooros and aohlovoment ratio may bo explainod in the colloming way. If we asame that upila who aro not well ndjuetad aocially as rionsured by the miliburno $3-A$ Invontory do not get along mell with thoir cominions. It is quito probable that t!oy associate and minilo loss wht theco gompanions. Those poorly ndfusted poople probably gpond lese timo in soolal activitiag and more timo on Intorestr ant tasks 1nrolving Indivislual attention. lorhaps bocause of th:1s oompretivo saclusion broulitabout by remor sociol contacts with tiolr oompanions, thoy havo moro tins to turn thoir intorosts tomerd school acomilishront. fos a rosult no this increased attontion to sohool tasks, thoy ure likoly to have hich achioromont rutlos. 

On the othor hand, uolng this same lino of arguent, it would som that those pupils who have more oolal oontacts and are bettar adj oted soolally to tholr oampantons, will probably spond loa timo on thoir sohool work and bo 108 s interosted in sohool aooamplishment; consequently they w112 have lower aohlevement ratios. Th1s 18 apparently what happens up to a oertain point, but beyond that point the botter a pup11 is adjusted, the higher his achlevement ratio bocomes. This may be explained by the assumption that exoollent soolal adjustment oarries with it advantages whi oh counterbalance relative seclusion from a soolal group, which is perhaps the greatest advantage of the poor adjustront group of pup1ls. It may be that exoellently adjusted pupils, by the very reason of thelr inoreased scoial contacts as well as more efficient use of their tiue, are able to inarease their achievenent ratios to a point whero they oxoel tho ahievement ratios of the intermediately adjusted group.

It is interosting to note the fact that the girls as a group soem to be a trifle better adjusted than the boys, as measured by tho washburne Soclal-Adjustment Inventory. The chief part of the differenoe is probebly brought about by the better adjustment of tho girls on such traits as truthfulnese, happlness, allenation, sympathy and impulse-judgment subtost sooros. The glrlo' sooros indicate only sllghtly bettor adjustment than the boys', exoept in the trait of sympathy where the adjustment of the girls 18 definitely superior to that of the boys. For the traits of puzpose and oontrol, the boyo exoel the girlo in adjustment. 


\section{TABLE 22}

Distrilution Showd $n_{b}$ tho Naletion of Achlovosont Ratlos to Mastiburno Totul Scoroo Givin, the thens for Eoye and Girls Soparately.

MASPBUURES TOTAL SCORTS

\section{Aohloveant} stotio

$$
25-74
$$$$
\text { 75-99 }
$$$$
100-24
$$$$
125-49
$$$$
150-74
$$$$
175-274
$$

Totn 1

10 to 19

1

1

1 to 9

7

$9 \quad 12$

10

5

49

-9 to 0

$17 \quad 46 \quad 36$

31

13

149

-19 to -10

9

28

21

12

8

$B 3$

-29 to -20

45

1

1

11

-39 to -30

1

1

1

3

\begin{tabular}{|c|c|c|c|c|c|c|c|c|}
\hline \multicolumn{2}{|c|}{$n$} & 34 & 85 & 76 & 55 & 27 & 20 & 297 \\
\hline \multicolumn{2}{|l|}{ s } & -6.4 & -7.9 & -7.6 & -6 & -5 & -7 & -7 \\
\hline \multirow[t]{2}{*}{ Strls } & $\mathrm{r}$ & 22 & 53 & 39 & 25 & 10 & 5 & 154 \\
\hline & u & -7 & -9 & -10 & -9 & -6 & -5 & -9 \\
\hline \multirow[t]{2}{*}{ Boys } & $N$ & 12 & 32 & 37 & 50 & 17 & 15 & 148 \\
\hline & $x$ & -5 & -6 & -6 & -4 & -5 & -7 & -5 \\
\hline
\end{tabular}

$E($ total group $)=\$ .752 \quad \mathbf{p}=.01-$ 




\section{The Rolation of Scores on tho "Link Invontory of Aotivities and interests (Porsonality Quotiont tost) to Aohieveront Rat1o.}

The Link Inventory or forsonality quotient toot 18 made up of rour subteste and an overall persanality scoro from which is obtainod the personality yuotient. The mohievement ratios for boys, Girls and total brour are compred with the personality soores. The Rolation of Achievomont Pntio to Social Initiative (S. I.)

The sooring on all of tho tosts hns boen arranged so that on all $8 \mathrm{cales}$ the higher scoros indicato satisfactory or dosirablo degreos of the trift. Tho trait, social initiativo, inoludes habits of taking the initiativo in mosting and dealing with pooplo. Table 23 and Fifuro 9 show the data collected on this variable.

Table 23 indioates that the distributions for boys, firls and total group closely approach the nomal. The mean for the total group falls in the 65-70 interval and the mode in the 59-64 interval, indioating the distribution is a bit skewod to the left.

The F test for the total group yields a value of 5.923 which is signiflcent at tho ono por cont level. There aro moro than ninety-nino out of one hundrod chances that a rolationship exists betweon achievement ratio and Link soolal initiative scores for thoso pupils of suporior intelligenoe.

The graphio illustration in Figuro 9 ohows considerable pluotuation in the relationship, artioularly at the onds of tho ourve whore the cases aro fow in numbor. In general, for both boys. girls and tho total group the relation between achiovement ratio and sooial inftiativo is smill but positive and 81 gnifloant. The conoral trand on the eraphio illustration 

Distribution Showing tho Ralntion of Aohlovomont lestios to Link Invontory wociul lnithutivo Svorus iving the Manne for Poys and irle Sopnratoly

\section{LINK INVEHYORY SOCIAL INITIATIVE SCORES}

\section{lohievomont}

Ratio 23-40 41-4 47-52 53-58 59-61 uj-70 71-70 77-93 83-E8 99-34 Total 0 to 19 1

to 9

5

9 to 0

69

2

1

2

19 to -10

26

29 to $-20 \quad 1$

39 to -30

1

9

8

5

G

$5 \quad 2$

41

$5 \quad 19 \quad 20 \quad 14$

26

18

10

7

134

(1)

$\mathbb{N}$

$15 \quad 15 \quad 10$

44

46

12

93

3

71

61

1

10

8

irls N

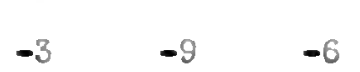

$-8$

$-7$

1

1

2

th

loys N

u

49

$6 \quad 21$

22

27

44

34

15

10260

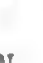

$-10 \quad-9=$

11

64

$-10$

$-9$

$-7$

$-6$

$-5$

$-6$

$-8 \quad-6$

y

$0 \quad-8 \quad-5$

23

$\mu$

$+2$

$-5 \quad-7$

24

18

22

19

5

$3 \quad 129$

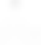

$-5 \quad-$

$F($ total group $)=5.923 ; p=.01-$ 

. 
Indloatos that high or good sooinl inftiativo sooros aro nasoointed with high achiovomont ratios.

It would appoar, thon, that lablte of taking tho initintive in montine. and doaling with pooplo aro positively assoolated whth achlovomant ratio. Possibly possession of soolal initintivo holps tho sujorior pupil to mot and boome aqualnted with his toachers and othors who may bo nulo to holp him with school work and oonsequently holp to inoraase his achiovoment ratio. Soclal inltiativo in tho classroom may cot moro attontion for tho superior pupll and so holp to incroaso his achiovomont ratio. Some suoh condition as those listod abovo will account for the positive relation found botween achievement ratio and social inftiative.

The Rolation of Achievomont Ratio to Self-dotermination (S. D.).

According to Link, the scale for this tralt consists of items reprosenting habits of doing things which are considered desirable even though they may bo unpleasant. An example vould be making friendly advances to [M.c. Ie you dislike, or studylng your lesezns whon you would rether go to tho movios.

Table 24 and Fifuro 10 oontain and 11 lustrato the deta oolleoted on this varlable for the puplls of superior intelligence who wore studied. Roferenoe to the frequonoy distribution in Table 24 shows that ansos are protty woll spread out in a distribution olosely approaohing the normal. Tho modo and moan for tho distribution for the total group ocours at the 56 to 60 intervil. which 18 tho mid intorval for this distribution.

The F test for tho total groug gives a mluo of 2.994 which is 8 ignifloant at tho ono por cont lovol; accordinely. thoro ls a signifionnt 

relationship oxiting botwoen nohlevement milo and tho Link Inventory solf-detarination sooros for thoog pupils of superior intolliganoo.

The graph in Figure 10 for tho total groun shows coneidornblo fluotuation, but tho relationsip is evidontly nogativo but small. Hig soores on the solf-determinution subtest of the Lirk Invontory. indioating excollent adfustmont, nro positively arsociated with low aohiovemunt ratios for the total proup; but. ns ono can geo from observation of Fliure 1C, this assoolation is of small degreo. It is also true that a pupil who is poorly adjusted as measured by the self-determinatica subtest is more likcly to have a he ahievemont ratio than a low one. There is considerable fluctuetion in the graphic rolationship for the total group. but oven more fluotuation is in ovidence for the Graphic relationship for the boys and firls. Ioth the curves for the boys and for the girls show a slight negativo association between achievement ratio and solf-detormination scores. The relationship in both cases is rery small and possibly would diseppoar with a larger samplo. At any rate, oven though tho ralationship is signifloant, it is of very small degrae.

It soems evident to tho writor that sovaral nthar paotor nust bo

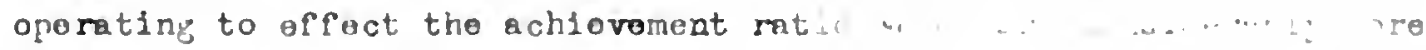
Imortant than the factor of self-detormination. Iuctuation in the Eraphio relationships and the foot that the relationghip is of very small de ereo botwoen achievoment ratio and self-dotemination sems to bear out this point.

It is a little dilicult to account :or. the pact that a sianicant nogative relationship exists between solf-detormination and aohievamont 
$-$ 


\section{TABIT 24}

Distribution Showle tho rulation of lohiovemont

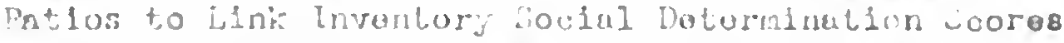

Giving the hosne ror Mus and uirle Sojaratoly.

\section{Le rement}

zatio

25-35 3E-10 \$1-\$5 46-50 51-55 56-60 61-65 6u-70 71-75 $76-80$ 81-95 Tatel

;0 19

1

1

:0 9

15

$5 \quad 5$

2

9

$5 \quad 7$

4

5

2

2

to 0

$7 \quad 13 \quad 10$

18

$1 \varepsilon$

$18 \quad 19$

20

12

5

49

to -10

3

$9 \quad 9$

$7 \quad 11$

$5 \quad 13$

8

7

7

83

to -20

12

2

31

2

11

to -30

1

1

1

$\mathrm{N}$

$18 \quad 14$

25

27

$27 \quad 41$

31

41

35

24

14

297

$-6 \quad-$

.18

7

$-8$

$\begin{array}{ll}-7 & -7\end{array}$

$-7$

$-7 \quad-6$

$-8 \quad-6$

$-9$

$17 \quad 25$

15

12

10

154

,

$-6 \quad-12$

$-8$

$\begin{array}{ll}-20 & -7\end{array}$

$-11$

$\begin{array}{ll}-7 & -9\end{array}$

$\begin{array}{lll}-9 & -7 & -10\end{array}$

$\begin{array}{lllll}11 & 8 & 10 & 17 & 9\end{array}$

$22 \quad 14 \quad 16$

20

12

4

143

$\mathbf{M}$

$-5-4$

$\begin{array}{lll}-2 & -6 & -6\end{array}$

$\begin{array}{lll}-4 & -6 & -3\end{array}$

$-8 \quad-5$

$-5$

$F($ Tatal Group $)=2.091 ; P=. \mathrm{Cl}-$ 



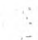


ratios. This signifioant rolationship. Elthsugh omall, may bo due to several fossiblo ceuses. In achievoment ratios ay havo a tendency to causo low solf-dotomingtion scores, or low self-determination scores may be oausing the his achievanent ratios, or both my be oaused by the third fector oporating to oontrol both. The Felation of Aohiovenent Fitio to Economio Self-Detemination

This sonlo on the Link Invontory moasuros the ability to earn ono's own living in reletion to personal ndjustment. "Ihe items of this scnlo consiet of habits of carning money by chores, selling tickets or mazinos, making tredes, otc. In othor words, zamplos of the disciplines and service required for eoonowic ends or work succose."154

Tablo 25 and Flgure 11 contain and lllustrate tho data oollected on this variable.

Feferonoo to the frequancy distribution indicatos that tho economio self-deteraination scores fall in a ratlor rogular romel distríbution. Tio modo falls at the 30 to 32 interval, whioh is the mid interval for tho distribution.

The $\mathrm{F}$ test gives a valuo of 5.320 which is significant at the one per cont level Thore is ovidontly a significant roletionship oxistinc between economio self-deterination scoros and aohievernant ratios for the suporior pupils studied.

Oservation of the graphic relationship for the total group in Figure 11 shows that this rolationship is nocative but girall. The 3

154 Lini. Bonry C. and others. liwnal for tho P.2. or ersonglity Quotiont Tost. (Inventory of Activitios and Intorost6) 1930 Ro-

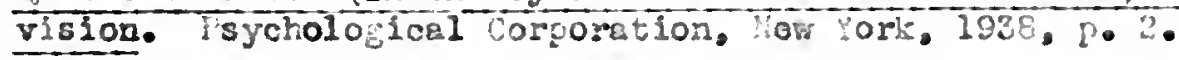



groups of pupilg having the highost monn achlovomont ratios fall at 3 widely separatod intervals in the ourve. The first group of puplls have vary low E. S. D. воогав, Indiosing poor adjustmont for this trait. The second group of pupl18, inving comarntively high moan achiovement ratic, salls in tho middle of tho ourve for tho total group. showlng average adjustment on E. S. D. The third group of high aohiovomont ratio puplis falls noar the upper ond of the $E$. S. D. curve, indlating good adjustment for E. S. D. General inspeotion of the curve for the total group reveals considerable fluatuation, partioularly at the onds of the distribution whore the number of cases is amall. If the onds of the distribution of aohievement ratios were to be removod, the distribution would be of the rlat boll-shapod ourve typo.

When the distributions for the boys and girle are oompared, It is observed that both are characterized by considorablo fluctuation. The boys who have the highest moan achievenent ratios fall at the niddle of the ourve. The graphic 1llustration of the relationship botwoen the cohievemont ratios for the girls and E. S. D. 800 res shows considernbly less fluctuation than that for elther the boys or the total group. The Girls with the lowest aohlevement ratios havo definitely the highest $E$. S. D. scores, while the girls with the highest achievement ratios havo the lowest E. S. D. scores. The negative relationship botwoen E. S. D. and achiovemont ratio is consequontly moro marked for the firls than it is for either the boys or the total group.

This small signifloant nogative relationship whioh exists botwoen E. S. D. and achievemont ratio may bo aoounted for in several ways. Pupils who are economically solf-roliant or who rank high in ablity to take oare of themselvas ooonomianly whilo attanding sohool aro more likely to be sponding a considorablo part of their timo at cortain 
. 
arter sohool jobs whloh w11l reduoe the amount of tine they oan a pend an their studios; consequently, their aohierement in sohool will not oome as olose to their oapaoity a might otherwise be expected. The degree of the rolationahip 18 omell and, in the opinion of the writer, merely presents ovidenoe that no positivo relationship exiats betwom the achlevenent ratio of puplis of superior intelligenoe and what Link allo conamio self-determination. This finding seems to be in agreamt wth the findings of others in regard to matters of vooational choioe and related varisblea.

It may be, too, that the association of low aohlevenent ratios with goad afjustment, as far sB ooonomio self-determination is conoemed. may result from other faotors influenoing this relationshdp. High ratiog for E.S.D. may bo associated with need or intention to lecte sohool early. This in turn may influenoe the achievement ratio to 8 omo considerable degree. Othor factors any influenoe the relationship indireotly in just such a manner.

The Relation of Achierement Ratio to Adjustment to the Opposito Sox (S.X.)

Th1s scale assumes that proper sex adjustment depends upon habits of ation formed carly in 11 fo toward mombers of the opposite sax. It Inoludes such Items a golng to mixed parties, learniag hor to drnoe. Table 26 and Figuro 12 oontain and 11 lustrate the data collected on this variable. Tablo 26 show tho diatribution of adjustront to tho opposite 8 ex soores for the total group to be 811 ghtly skewed to the lort. The greater number of ooores tend to fall in the uppor half of the distribution. Indiating that the groater nuenbor of these pupils of superior Intelligenoe are well adjusted toward tho opposite sex, 


\section{TABLE 25}

Distribution Showlng tho Rolation of Achlovement Ratios to Link Inventory Eoonomio Solf Detormination Scores Giving the Manne for Roys and Cirls Soparatoly

\section{LINK INVENTORY ECONOMIC SELF DETERIINATION SCORES}

\section{levement}

Retio

to 19

09

to 0

to -10

to -20

to -30

N

M

-18 N

v

$\mathrm{N}$

I $6-17 \quad 18-20$

1

1

5

2

1

1

6

$6 \quad 6$

$9 \quad 16$

$30-32$

$33-35$

$36-38$

$39-41$

$42-44$

$45-50$ Total

1

$\begin{array}{lllll}6 & 9 & 5 & 9 & 4\end{array}$

$8 \quad 8$

$27 \quad 21$

20

19

10

44

76

14

10

18

31

1

1

1

I

$10 \quad 14 \quad 20 \quad 25$

29

53

37

48

30

16

5

1

$\begin{array}{lllll}-6 & -9 & -7 & -8\end{array}$

$\begin{array}{ll}-6 & -7\end{array}$

$-7$

$\begin{array}{llllll}2 & 8 & 8 & 14 & 19\end{array}$

32

22

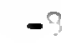

$-6$

25

14

$-7$

$-9$

$-10$

$-9$

21

15

23

16

11

$\begin{array}{lll}-5 & -4 & -10\end{array}$

$\begin{array}{lll}0 & -6 & -6\end{array}$

$F($ total group $)=5.326 ; p=.01-$ 



evidently more so tian any of the othor throo traite measured by tho Link Inventory of Activitios and Intorosta. Tho mode for the distribution falls at tho 32 to 34 interval, whl ah is quite dofinitely in the uppor half of tho distribution. Tho distributions for the boys and girls are skewed definitely to the left, whare adjustment to the opposite sex scores are conoerned.

Perhap it should bo noted that, of tho 41 cases in the total group shoring the best adjustment for opposito sex, all of then are girls. It seam evident that it is due very groatly to the influenoe of the girls that this auperior group of puplis possesses better than average adjugtment to the opposite sex.

When the $F$ test is applied to the distribution, a result of 13.552 is obtainad. This is $81 \mathrm{gnifl}$ cant at the one por oent level and Indiates that there is a signifiant relationship axisting botween adjustment to the opposite sex and aohievenent ratio for the total group of pup1ls of superior intelligenoe.

Reference to Figure 12 shows that the relationship is definitely negat1ro. Puplls having high achlovenent ratios aro $11 \mathrm{kely}$ to have Iow soores on this subtest, indioating poor adjustment to the opposite sex, and pupils having low achlevement ratios are likely to have high coores on this subtest, Indioating good adjustrent to the opposite sex. This rolationship holds for both boys and girls as woll as for the total group.

There is some fluotuation in the negative rolationshlp rist oh sens to oxiat botween aohlevenent rat1o and adjustment to tho opposito cor coores, and thls liuatuation inoresses when the boys or 61rls are conoldered apnrately. 



\section{TABLE 26}

Distribution Showing tho Rolation of Aohiovomont Ratios to Link Inventory Adjustment to tho Opposito Sex Soores Giving the Means for Boys and Girls Separately.

\section{LINK INVENTORY ADJUSTMENT TO THE OPPOSITE SEX SCORES}

shievement

Ratio

$$
2-10 \quad 11-13
$$

1$$
3
$$

36

$7 \quad 6$

4

3

5

7

5

3

49

to 0

$$
9
$$

3

$10 \quad 11$

16

16

16

18

23

$27 \quad 149$

9 to -10

$$
2
$$

2

4

4

8

616

12

21

8

83

9 to -20

1

21

2

1

2

1

1

11

1

99 to -30

N

$16 \quad 12$

22

22

30

27

38

39

2

3

M

$-4 \quad-3 \quad-$

rls $\mathrm{A}$

M

ys

X

32

$-5$

$-5$

$-7$

$-8$

$-8$

$-7$

19

20

33

41

154

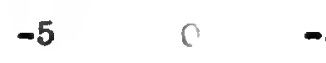

$1310 \quad 1$

$-4 \quad-4 \quad-5$

$-6$

$-3$

$-6$

$-10$

$-11$

$-9$

$-8$

$-9$

H

$F($ total group $)=13.252 ; p=.01-$ 

, 
The nogative association botween aohlevement ratio and adjustmont to the opposite sex, whloh holds for the boye, girls, and total group. may bo acoounted for in a number of says. The puplls who noquire, probably through a number of personal contacts with the opposite sex, an excellent adjustmont to tho opposite sex probably spend less time and are 1 ess interested in sohool work. Comsequently. they mohlove ocmsiderably below what might bo expected of puplis of their Intelligence.

The fact that the girls are so muoh better adjusted to the opposito sex than the boys if tho moan ashiefenent ratio for the girls is oonsiderably lower than the mean achieremen rat1o for tho boys. ca the other hand, pup1l. who do not do so weil in school or whose adjustment oomes furthor from their prowles lhan ufkt ordinarily be expected, may turn to the opposite sex for an outlet for tholr energios. The Relation of Achlevement Ratlo to Porsonality Quotient

This scalo Inoludes all the items of the inventory. As IInk155 explalns. "the possersion of hablts whioh interest and serve other peoplo." Personality quotient may bo interpreted as the intelligenoo quotient, a soore of 100 belng avorage. On this test, 150 puplls reoelved P. Q.'s of loss tinan 98, wh1le 103 pup1ls rooolvod P. Q.'B of over 105. The mode for this partioular tost foll at the 88 to 105 Interval. where there are 55 cases. Judglng from these resulta, 1t appears that this superior group of pup1ls had just average porconality quotionts. 
Iable 27 and Mgure 15 contein and 11lustrate the data an peraonality quotiant. Tho dietribution appoers to bo vory olose to normal. It 18 interesting to note, howeror, that 54 cnses. 1noluding 24 girla and 30 boys, have derinitely low Link porsonallty quotients. but this is oounterbalunoed by 67 cases. 35 Elrls and 24 boys, who heve dorinitely suporior porsonallty quoticnts. The distribution of P. G.' for the boys and firls clocely upproachos nomal distributione. kut the diatribution for the boye la skoved a kt more to the right with a lower moan $P . Q$. than that for the (1) 18

When the F teot is applled to the total distribution, a value of 8.\$4l is secured, whloh io sifnlfloant at the one por cent levol. A algnificant relationsif pex sto botwoen porsonallty quotiart and aohievenent rat10. Observation of the graphlo rolationshlp if Figure 12 Indiostes that this rolationship 1 o notive, but to a sull degroo. When the group as a whole 13 otudiod. It 16 obsorved that the meen achioroment ratio for the 55 ases having arerage P. Q.'s (98 to 105) Is lower than that for any othor category seleoted. Ihis is truo for tho girlo, and with one exoeption true for the boys. It would seec that avorage persoaslity guotiont 18 assoolatod with Iow achlevement ratio, that low porsanallty quotients aro assoolated Wth high achioremeat ratio, and that high poraonality quotients aro asscolated. too. Wh thigh achievoment ratio. This is true for boys Glrls and total group with little axcoption.

The nogative relationohip whi oh exlata botwoen aohiovement ratio and persomallty quotiont nay be acoountor for in a number of ways. Elrst, although the ralationohip is significant, it is ovidently vory 

small. To the writer, this is muro of an indiontion that a positive rolationship botwoen porsonality quotiont and achioroment ratio does not oxist than 1 t 16 an indloation that a nogativo relationship botwoon aohievomont ratio and porsonal1ty quotient does $-x i s t$

The as8ooiation of low personality quotiont with ligh aohlorament ratio, although small, may be duo again to a timo ractor. Pupils having moro outside intorests and tending to spond nore tiro in social activitios and cultivating frionds are moro likely to spend less time on tholr school work and, consequontly, achlove loss than might be expected of them. Perhaps this is more pertioularly true of the Elrlo than it is of the boys. It is likely that the glrls are more interested in soolal contacts likoly to devolop their personal1ty than thay are in hooks; this is probably true of boys to a lesser extent.

This is probably true up to a oertain point, but tho assooiation of avorago fersonel1ty quotients with lowest aohiovenont ratios introduoes a oompliontion. Probably the same thing is indionted horo as is indioatod by tho Vistiburne S-A Inventory soores.

Better adjusted pupils spend loss timo on sohool work, and tholr aohieverent ratios suffor. Poorly adjusted pupils ifth low P. Q.'s have fewor soolal contacts and more time for sohool achieremont. The boat adfusted pupll having an intermodiato cohiovement ratio probubly has arrivad at a happy modium and so attaina an intormodito achievomont ratio 


\section{TABLE 27}

Distribution Showing tho Rolntion of Mohiovoment Ratios to Link Porvornlity Quotionts Giving, tho ldoane for Boys and Girls Soparatoly

\section{LINK PERSONALITY QUOTIENTS}

Aohloveinent

Rat1o 50-73 74-81 82-89 90-97 98-105 106-113 114-121 $122-137$ Total

10 to 19

1

1

2

1 to 9

4610

9

8

6

2

49

-9 to 0

$13 \quad 14$

15

27

20

27

16

149

-19 to -10

10

12

10

19

12

12

83

-29 to -20

1

1

3

6

11

-39 to $-30 \quad 1$

1

1

3

\begin{tabular}{|c|c|c|c|c|c|c|c|c|c|c|}
\hline \multicolumn{2}{|l|}{ N } & 23 & 31 & 37 & 49 & 65 & 45 & 27 & 30 & 297 \\
\hline \multicolumn{2}{|c|}{ M } & -6 & -7 & -6 & -6 & -9 & -6 & -6 & -8 & -7 \\
\hline \multirow{2}{*}{ Girlo } & $N$ & 8 & 16 & 18 & 19 & 33 & 27 & 14 & 19 & 154 \\
\hline & $\mathbf{y}$ & -10 & -8 & -7 & -8 & -11 & -7 & -9 & -8 & -9 \\
\hline \multirow[t]{2}{*}{ Boys } & N & 15 & 15 & 19 & 30 & 22 & 18 & 13 & 11 & 143 \\
\hline & $\mathbf{x}$ & -5 & -6 & -4 & -5 & -6 & -5 & -3 & -10 & -5 \\
\hline
\end{tabular}

$F($ total Group $)=8.941 ; P=.01-$ 




\section{Porsonnlity Summary}

The gonoral trond of tho relationship botwoen achiovomont ratlo and lorsonality, as measured by both tho Vishuurno SoolalAdjustment Invontory and tho Link Inventory of Activitios and Interests, is the samo. It appoars that tho rinding outainod from the results of both poroonality toste are in gonoral apreomont.

The Link Personality Quotient, whioh is moroly a sumery of tho various subtest soores, and tho Meshuurne total scores, whioh is a sumary of the washburno subtest scores, show the same relationship with the aohiovomont ratios of the pupils studied. In both casos, poorost porsonality adjustmont is assoolatod with highest aohiovoment ratio, intermediate personality adjustment is assooiated with lowest moan achlevement ratio, and highost porsonality adjustment is associatod with intermediate moan achievement ratios. It soems quite ovident that the rolationship whioh oxists hetween nohievement ratio and personality is not a positivo rolationship, but that it tonds to bo nogative. Apparently, howevor, that large group of pupils who have normal personality adjuttment also have something whioh roducos tholr achlovement ratio.

Tho rosults found horo aro not in agrooinont with thoso raportad

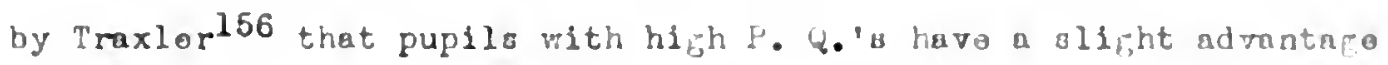
in aodemio compotition. Accordine to tho rosulte fivon abovo, punils with hich $P$. Q.'s havo a slist advintago in

156 Traxlar. A.E. "Curront Construotion and Evnluation of Forsonality and Charactor Tosto". Ruvlow of Eduontional Rosearoh. Fobruary. 1941, p. 60. 

oompatition over those puplis who hevo avorule :-4.'B, but tho puplis who havo low P. 4.' 3 hevo un advantafen ovor loth the pupils who havo averape and over those who havo hifh personality quotionta, as lur as acudonio compotition mousurod by uchiovomont rutio is concornod.

It must be remembered that porsonality testo unfortumutoly do not always nousure accurately a pupil's tomporamont and, us a result, suoh faulty moosuros compared to achiovonont ratio may bring inconolusivo rosults.

Stagnerl57 writos in general afroments

1. Linear correlations of intelligonce, achievement, and personality measures are low and are probably so as a result of the inherent nature of the relationship.

2. Extremo personality trends soem to counterbalance advantaces in aptitudo, making for equal achiovomont in opposed groups. High omotionality and hich self-sufficiency lead to lower achiovement than would be predicted from intolligence scoros.

It is quite posiblo that oven if there wore a positive rolationship existinf, botwoon forsonality and achievoment ratio; poor personulity might not cause poor achievement ratio, but that the reverse may be true. f'ailure to work consistently up to one's aapacity may demoralizo tho personality. 
THE RELATIUN OF HORE BACRGROUNDS TO ACHIEVEWENT RATIO

A. Sins Socio Eoonomio Status

B. Forolgn Lanfuagea spoken in tho llomo

C. Number of Amorioan Born Crandparonto

D. Antocedont's Country of Birth

E. Father's Education

F. Rothor's Education

G. Number of Siblings in tho Fanily

R. Sibling's Position in the Fanily

I. En uf ronment - Rural or Urban

J. Family Kiosidenoe - Broken or Intact Funily

K. Rupils lloalth I \& II

L. Parants Hoalth

น. Rupil's Physical Defoots

N. Hane Disciplino

0. Paront's iorking

P. Study Habits 

The Relation of Achievanont Ratio to Sims Soclo-Eoonomio Status

The Sims Score Card for Soolo-tioonanic Statas was dovolopod to provide a simple, convenient, and objective devico for determining the oultural, sooial, ind eoonomio baokgrounds furnishod by the homes of school children. It consists of 23 questions raneinf from whother there is a telephono in the home to what the pupil's fathor's occupation is. Thesores on this test were arranged into 10 socioeconomic status classes set up by Sims, class 1 bolng vory inferior. class 10 beinf extromely superior. Cases in this study wore classified aocordingly.

\begin{tabular}{|c|c|c|c|}
\hline Soolo-Eoonamio & Boy 8 & Girls & Total \\
\hline Cless & & & \\
\hline O-Indeterminately Low & & & \\
\hline 1-Lowest & - & - & - \\
\hline 2-Very Low & - & - & - \\
\hline 3 -Low & - & 1 & 1 \\
\hline 4-Modium Low & 3 & - & 3 \\
\hline 5-Yodium & 16 & 22 & 38 \\
\hline 6-jodium High & 35 & 36 & 70 \\
\hline 7-High & 66 & 58 & 124 \\
\hline 8-Very HIgh & 18 & 32 & 50 \\
\hline 9-H1 chest & 5 & 6 & 11 \\
\hline 10-Indeterminately $\mathrm{Hi}_{\mathrm{E}} \mathrm{h}$ & - & - & - \\
\hline TOThLS & 143 & 154 & 297 \\
\hline
\end{tabular}

As can be soon from the abovo froquenoy dlotributian of $31 \mathrm{~ms}$ Socio-Economlo sooros by classes, tho vory groat majortty of casos : 11 in modium to hifhest socio-joonomio statas clusses. This fropp 
. 


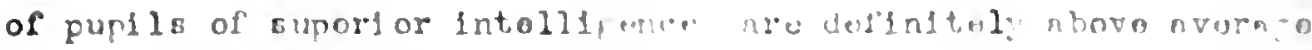
In soolo-oononlo status.

Table 28 and Fipure 74 rive the data colluct on on the relulionship of this variable S. I. S. 10 nobienement retio. Ma t tust yiolds a velue of 6.132 which is el priflcant at the ono per curit

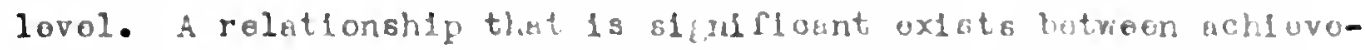
mert ratio ard soclc-econoric status for these gulla of superior intolifenoe. Fipure 14 indicatos that this ralationship for the total froup is lineer and positivo. Lvidently a high actisycrent ratio is assoolated with a high soolo-economic status score lor puplis of superior intelligenoe.

With the exooption of Blight Iluetuations at the end oi the ourvo, this signiflont positive linfar rolatlonahp betwoon aolisevement ratio and socio-oconon c status appaurs to exist for both boys and eirls as well as the tutal gruup. The boys nt the lower eni of tho S. 5. S. distribution do not have the very lovest achiuvamunt ratios for tho boys, and the 1 rls at the upper ond of the is. L. 3 . distribution do not have tho verg hiphest achiovenunt ratios for the girls; w1th thase two oxooptlans, howevor, the A. R. - j. . S. curvo is unfors, indioating a derindte signifloant positivo linuar rulationahip betwoen aohlovement ratio and soolo-econvalu Etetus f'or boys, firls, and the total group.

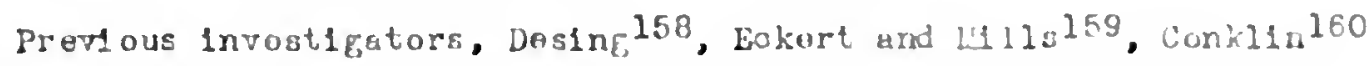
are agreed there 15 little diffarenoe botweur the l:ome sott1ni or gocio-

158 Desing, Linerve F., op. olt. pp. 18.19.

159 Eckort, Kuth L. and IIIIs, lenry C., "Varlatlons Amone, H1ph Sohool Santors in Promd se and Porformance lensures". Sohool Rovi ow. $44,274-282$.

160 Conklin, Aprob, op. o1t. p. 114. 



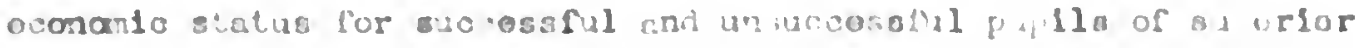

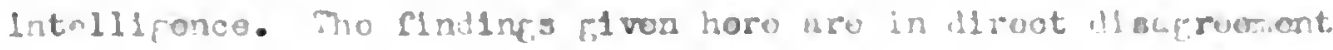
on t.ils point.

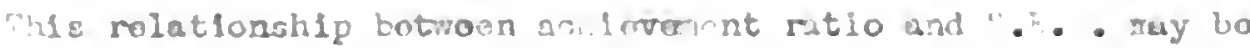
uccountod for in u numbor of wyyb. In fonorul, a buttor sooial and

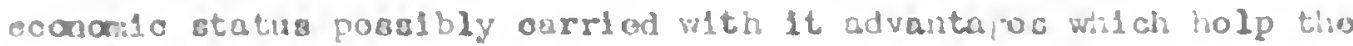

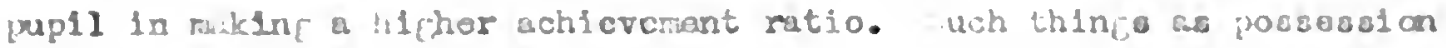
of mer: books in the hane for soforonoo, zoro roome in the houso allowinf rore privueg for study, bottar odicutad poronts, wey all ald tho

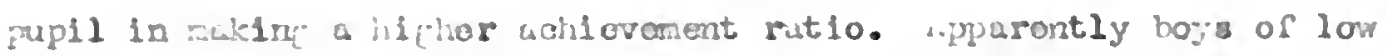
soc10-ocanonlo statis havo lose troublo than firle in ovoroondne thin dieadrantice and. onsoguently mko botter achlevenant rotios. sppar ontly. tow, a vory hich achlevamont mito is a disadvantaco for 1 rle. but not for boys. ilrls of hich socto-oconomlo status prossluly havo rolatively soro outeido 1.2terosts so that thal echoul work siffera and thule achleverieat ritio fells.

un the othor suad. hich achiovesent ratlos on tho part of ctudents may rosult in puplis and l:asos in poral having a hifhor sooio-conante

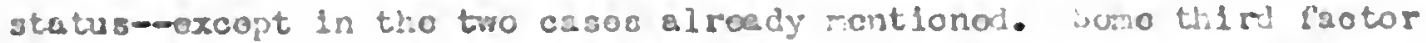

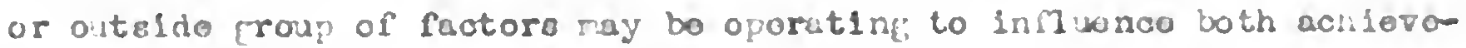
mont ratlo and socio-ooonon" o status. Why or ull of Wioso tuln, may bo actine to bring abost tho positivo sifnifloant rolationatip fosnd botwoun acilovanont ritio and sociomoononic siabus.

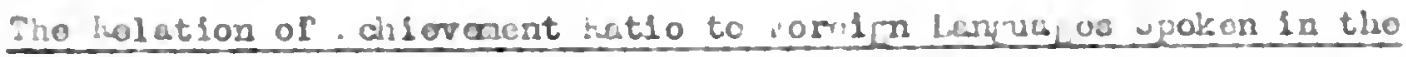
Ilome

vary pupll includod in the etudy was ackod to list tho nuzbor

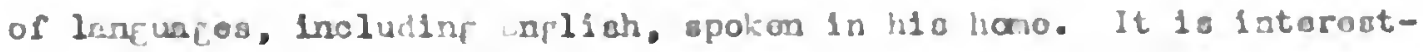
ing to noto that 12 difforont forolg lunpug os wro spoicon in tho howos of 297 pupils of superior intellifianco who aro ind luded 



\section{TABLE 28}

Diatribution Sharine tho Rolution of Achlormont

Ratlos to ins Soclo-liconomic Stutus lnasos Givine, tho Noans for Bays and lifls Separatoly.

\section{SIMS SOCIO-ECONOMIC STATUS CLASSES}

$\begin{array}{lrrrrrr}\begin{array}{l}\text { Achioveront } \\ \text { Ratio }\end{array} & 3-5 & 6 & 7 & 8 & 9 & \text { Total } \\ 10 \text { to } 19 & 1 & & & 1 & & 2 \\ \text { I to } 9 & 4 & 8 & 24 & 9 & 4 & 49 \\ -9 \text { to } 0 & 15 & 35 & 62 & 34 & 3 & 149 \\ -19 \text { to }-10 & 19 & 23 & 33 & 4 & 4 & 83 \\ -29 \text { to }-20 & 2 & 4 & 3 & 2 & & 11 \\ -39 \text { to }-30 & 1 & & 2 & & & 3 \\ \text { N } & 42 & 70 & 124 & 50 & 11 & 297 \\ \text { U } & -10 & -8 & -7 & -4 & -5 & -7 \\ \text { Girls N } & 23 & 35 & 58 & 32 & 6 & 154 \\ \text { M } & -14 & -9 & -8 & -5 & -8 & -9 \\ \text { Boys N } & 19 & 35 & 66 & 18 & 5 & 143 \\ \text { N } & -5 & -7 & -6 & -3 & -1 & -6\end{array}$

$F($ total group $)=16.132, P=.01-$ 
$-$ 
In lic stidy. 2ls of the papla 11 vo in harbe L." oh only fila Is ispolitur.

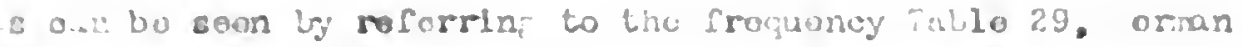

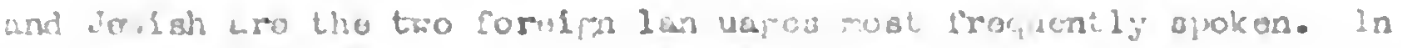

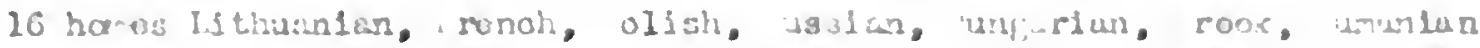
or :antah aro snokon.

Pho distribution, of casse. Is ifhly skovod to lha right bo cause of thie al zo of tio cutoiory of no forolin langaro epoicen. "hile is true for bo:s. firls en! tho total rrop. The tegt yiolda a vulup

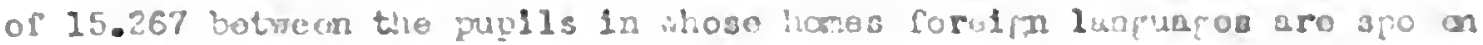

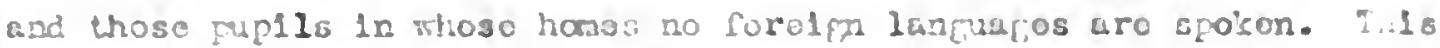
10 sf rnifleant st thic ono per cont level.

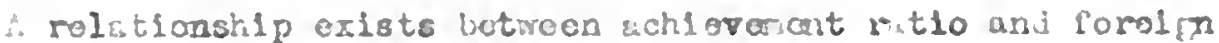
lampares spoken in the honc. Hifure 15 showd criphlealig for tio

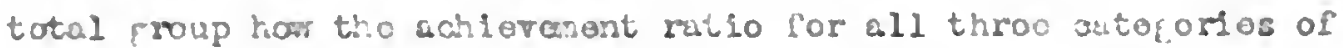
mpils in moso hasos forelgn lameuaros ero spokan oxcelo in man

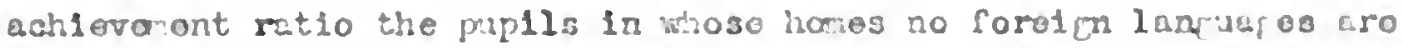
spolson. In cther vonds, whore tho lotal proup is oonocriod, hich cohleverant milo is associntod with forelon lancuar o3 spokon in tho home.

"hon tho achlorement ratlos for the croups who 19 wo in homes in which a forclin langlage 13 spocon ara rankod acconiln to varlois lunplatos, it lo notlood that the miscollanoous roup of 16 cusos has tho hlphest everero achlevoront ratio, tho Jould roup of 51 cacos has the noxt hichest avoraco achlowont ratlos the coran croup of 17 oases ranks third in avorajo ashlevonont ratio and tho proup of

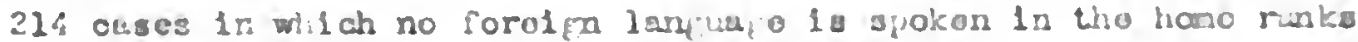



last in mour achiovemont rutio.

This same situation is truo with vory litho viriation for tho boys, the only differonce bofne, thit the mon nchlovomont rut 10 s $\mathrm{by}$

runk aro as follows: (1) Mioollanoous, (2) Coman, (3) Jowigh, (4) no foreipn languago.

Fifuro 15 shows that the mean achiovanont ratios for tho frls varios from both bys and the total group. In tho cuso of the rirls, thore is a difforono in tho rankinf: by moan achievonont rutios. Tho Eirls in whoso homes no foreign linguares are spokon oxool those firlo In whose hamos both Gorman and Jowish are spoken, but thoy in turn are oxcolled by the miscellunoous group in moan achievanont ratio. Evidontly, the sipnificant relationship wich exists betwoen achiovocont rutio and the presonce or absence of foreign languagos epoken in the homo is duo largely to the influence of the boys.

If a foreign languago is spoken in the hame, it is fairly good ovidenoe that somo marber:s of the fanily have not boon in wnerica their ontiro lifetino, cortainly not lone onough to forget how to speak their native tongues. It may be that in some oasos the fuct that the forolgu lunguges aro s oken in the homo is an evidence of superior education and knowlodge of languages not nativo to the farily, but tisa ia probubly the exoeption ruthor than the rulo.

If, thon, wo aseumo that the fact that forolifn languages wro spoicen in tho home is an adoquate criterion that poollo in tho homes havo boon inderants not too long ago, how cun wo oacount for tho fact that pupils ooning from homos in wioh forolg lanpluagos aro spokon havo u hifhor moan achievement ratio than "nativo" pupila? inut is tho dir- 



\section{TABLE 29}

Distribution of faldovenent iution secordine to

Eorolin Languees spokon in ilono Cirine tho soans for Boys and Girls Sogurately.

\section{EOREIGIN INNGUAGLS SIOKEN III HONE}

Achievameat Ratio

10 to 19

1 to 9

-9 to 0

-19 to -10

-29 to -20

-39 to -30

\begin{tabular}{|c|c|c|}
\hline $\mathrm{N}$ & & 214 \\
\hline W: & & -8 \\
\hline Girls & li & 130 \\
\hline & $k$ & -9 \\
\hline Boys & Ii & 84 \\
\hline & Li & -7 \\
\hline
\end{tabular}

30

2

64

11

2

1

$$
\text { Jow sh }
$$

ilis scell ancous

Total

1

1

2

4

13

2

49

$107 \quad 12$

24

6

149

17

83

11

3

19

55

9

297

$-6$

$-5$

$-2$

$-7$

1

9

4

154

$-9$

$-6$

$-9$

10

5

143

$-3$

$-1$

$-5$ 



feronon botwoon the boys and, irle wilah gacounts for tho lower mean achlavemt rntio for tho firla who como from home lin whioh forvign

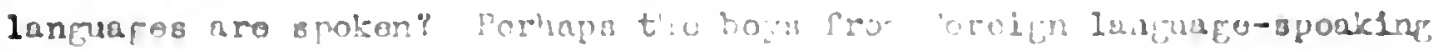
fardlios fool that thoy havo a handicap and work hardor to ovorcane it. The boys como in preater contuct whth the outaido Arierican world und posaibly aro moro influenoed by it than firls my be. Theso ure possiblo explanations for the differencos found.

It wns intorostine, to noto here that of tho many poolo of Polish and lussian descent, only 9 livod in loncs shero folish or husian vus spoken, while in the comparativoly smallor roup of olildron having German antocodents, 20 11ved in homos vacro Cerman was spoken. It would seam that the Rusians and Poles are much more asily assirilatod into our umorican way of life than cre the Gormans, if a forctell Imuge spoken in tho hone oan bo used as a critorion.

This micht bo oxplainod by tho fact that the Russians or toles, instead of spenk1nf Rusian or Polish, may be nubured anont thoso 51 cases in whose homos Jentsh is spokon.

The Kolation of Achievozont Ratio to the liumbor of Anorloan Bom Grundparcists.

Every pupil in tho study was askad to find out and list tho country of birth for ach of his four rrandparonts. Tho numbor of smorloan bora grandparents belonpinf, to any one pupil was solootod as ono variablo to be compared with the aohiovoment ratio.

Roforonco to Tuble 30, giving distribution of achlovement rutios

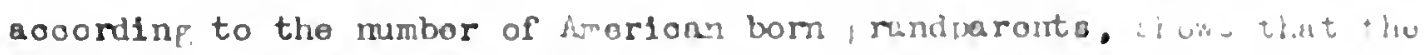

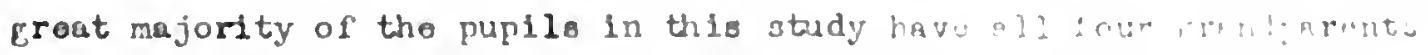
born In Amorica. Consequontly, tho dietributior is hnvily chencd 



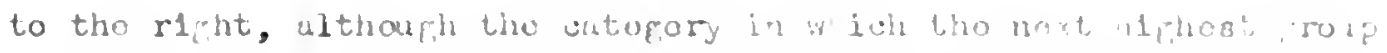

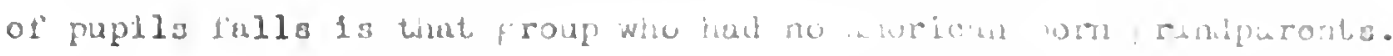

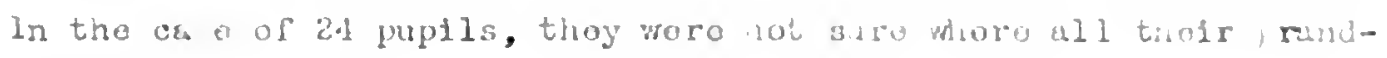
paronts wore lorm.

lino tost ras upplied to this rolutionalp, and u vilo ol 11.014 was olvtured. Tuis wros sifnilluat ut tho one per cont lovel, 1I-

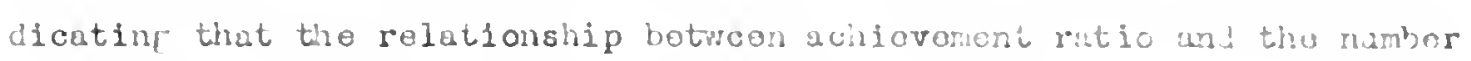
of imorian born crundpurents is hilli, sipnificant.

inoforenco to tho Eraph in $f$ curo $1 i$ shory that tho amsler tinc number ol' morican born Erandparonte a pupil mey liavo, the hicher his achievomont ratio is likoly to oc. This rolutionship pluctuates qulto

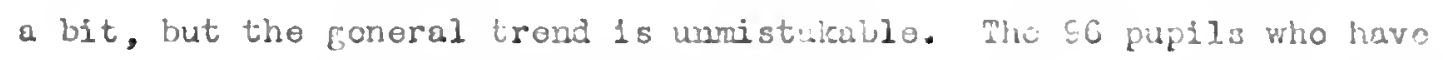
no inericun born cradparents aru slightly oxvollad in soun wchicromont ratio by the 6 pupils who have ono werican born Erundparent, but they excel in mean ichievenent ratio the 3 other groups of pupils who havo 2. 3, and 4 therican born Erandparents. Tho 17 pupils who have $\Xi$ Snorican com randparents cxcellod tho pup1ls who hato 2 anorican born crandparents, but no other group cxcopt those pupils who bavo 4 hinorican born runiparents.

The boys differ slichtly from tho firls in the rolationship which exists between achievemont ratio and the number cf "areric.n bom randparents. The significunt rulutionship wich oxists botvoon hich achiovoment ratio and a small numbur of inoricun lon frundparonts existe to a proutor dogroo for tho pirls. .ruin, two rirls who huvo onc wiericen born crandparont havo a lowor mocn uchiovelient rutio than 34 firls who havo no warioan born numbrents. vor ovorjothor catucory, hovovor, tho pup1ls who havo no h oricus born ranipuronts oxel 

thoso who huvo 2. 3, or 4 hmoricun iorn prundparonta. Agaln, that eroup of lifrls who huvo 3 hrorioun bom prondpuronts slithtly oxools

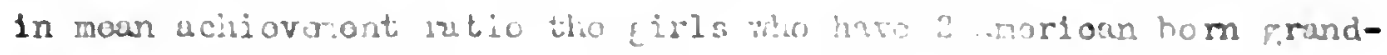
paronts. "hore tho boys aro concornod, thoro is conaldombla iluat-

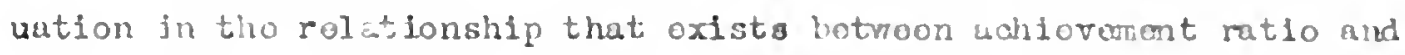
tho ranber. A Amorioan born [rundparonts. The 62 boy with no imorican bom Erudparents and the 4 boys mo havo ono hmorican born Erandparant hive the samo hown achloremont rutio. The 13 boys who have 2 Anorican born erendparante and thic 33 boys who huve $4 \mathrm{hmcrican}$ born grandparonts baro the ssinc mcan achiercient rat10, but it is oonaldorably laror than tho mean achiovement ritio of tho boys mio havo nono or ono Morican born Erandparont. "hore aro 3 boys who hrvo 3 Wroricar born Crandparonts whosc mean cohievenent rutio excols any of tho othor groups. It is tilis groil wich is responsiblo for tho seaning ereat amount of sluctuation wich oxists in the rolationship for the boy3. It appears that for boys, hiph achicvement ratio is assoclated with a low aubibr of Imorican bom frandparonts, but tho defreo of the rclationship 13 not quito as erat as thet which oxists botwoon tho high ächiovomont ratio for firls and a low mubor of horloan born grondporente.

This sifnificant rolationship which oxists botseon tho numbor of Amoricar bors frandparonts and tho achievemunt ratio may bo acoounted for in a number of ways. Apparontly. pupils who tre of roout foreich extraction, as moasured by the numbor of crandpurents who wero born in forolgn countric, rooolvo nomo additional stimlug to wahiovo whiloh puplis who aro not of rocont corolgn extration lo not rooolva. Porhaps 1t is booause thoy fool that tioir forulg uxtraction is a handoup 

Distribution of Achiovanent hutios acoording to

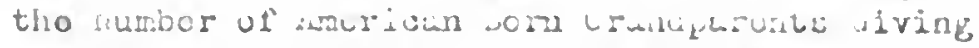
the Leans for Boys and Cirle vounretoly.

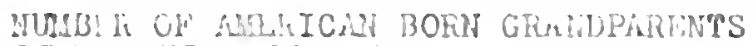

Sohievumurst

$\begin{array}{llllllll}\text { Rutio } & 0 & 1 & 2 & 3 & 4 & \text { Unknown T'otal }\end{array}$

10 to $19 \quad 2$

2

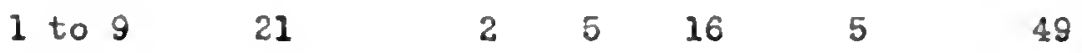

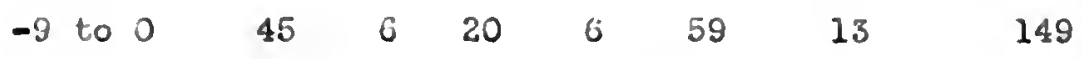

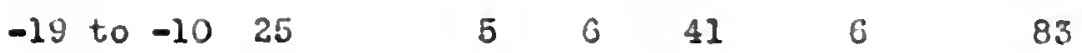

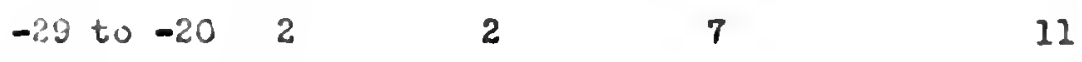

$\begin{array}{llll}-39 \text { to }-30 & 1 & 2 & 3\end{array}$

\begin{tabular}{|c|c|c|c|c|c|c|c|c|}
\hline NI & & 96 & 6 & 29 & 17 & 125 & 24 & 297 \\
\hline L & & -6 & -5 & -7 & -6 & -3 & -5 & -7 \\
\hline G1rls & $\because !$ & $3 \frac{1}{x}$ & 2 & 16 & 3 & 87 & 6 & 154 \\
\hline & w & -7 & -5 & -3 & -7 & -9 & -13 & -9 \\
\hline by 8 & :I & $c 2$ & 4 & 13 & C & 38 & 18 & 143 \\
\hline & L & -5 & -5 & -7 & -4 & -7 & -3 & -5 \\
\hline
\end{tabular}

$F($ total Eroup $)=11.014: 1=.01-$ 



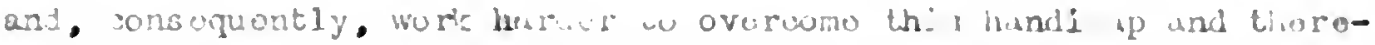

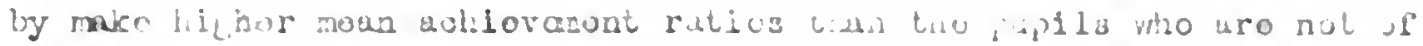

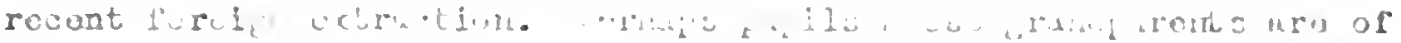
Sorolin cxtruation aro noro likolj to approcidto tho opportinition prantal by imoricin eduoution, consoquently norle hurdor, tiaroby rabine hi jior achlevomout rutiou.

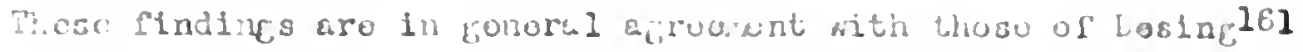

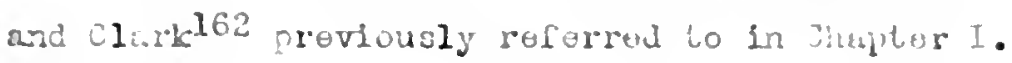

Tho Nolation of Achio anont Iatio to kntecodants' Country of Birth

4. rumber of variablos were included under the hoading of antosodents' country of birth. Thoy urc listed bolor:

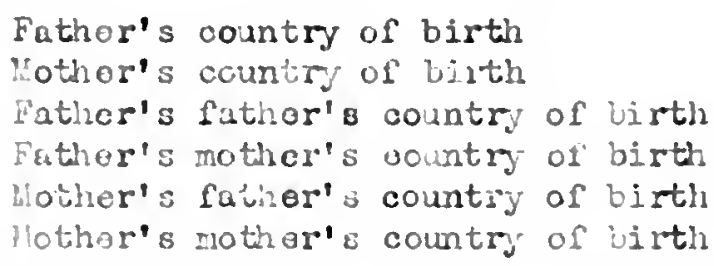

mo relationship of tho numbor of molicun born frundp-ronte to achiovomont rutio hag already boon foind. The rosults lead us to Dolieve thit tho smaller the numbor of imerican boln grandparonts. the hichor tho mean achievenont ratio for thoso suporior puplas studiod. Tho relationshin betwoen achievanent ritio and the erundpuronts' country of bith is now troatad moro extonsivaly, talini the ountry of birth of ono type of erundluront \& $t$ a time. The rolationahip betroan tho achievement mitio and the paront, $3^{\prime}$ country of birth is inoluded.

161 Dosine, linarra F. O, oit. pp. 107, 14:-141.

162 Clurk, E. L. op. olt. pp. 237-238. 

inly tioso oountrios whioh aro ruprosontod by 10 ur roro onsce aro 1colubod in sepurete oulogorios. Countrios in wich tieno ure

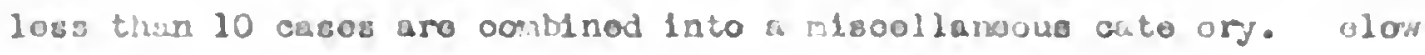
is 1 istod the moan udiovanont ratio rank f'or and lypo of antooodents

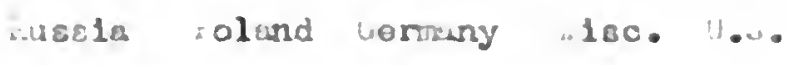

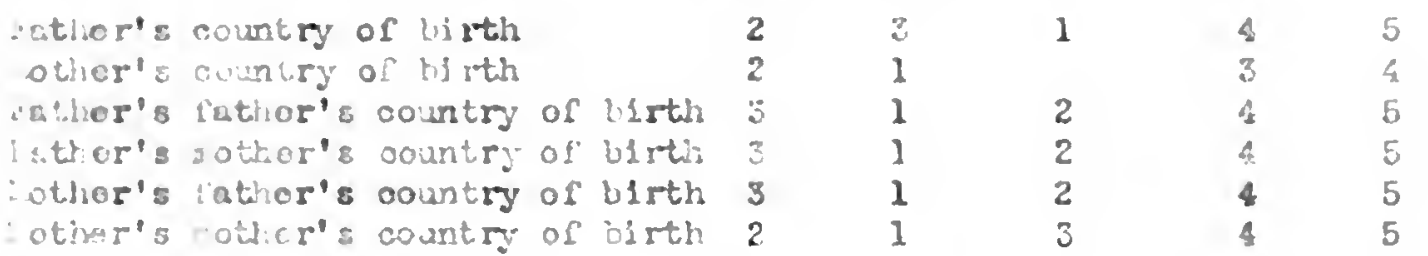

It $41:$ be notod hore thet the rited tates runks last in ovory

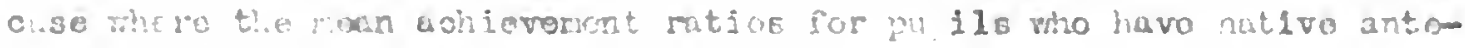

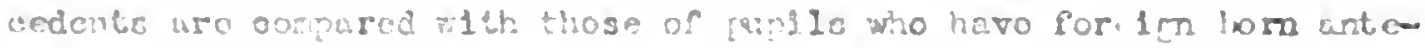
sadents.

- uliur's country of birth is the firet murable that is consldored ro sutoly. "ndor this nirisule tioro tore only 4 catororlos In milch thoto aro 10 or norc cucos. Tho froguency distribution in S.ovlo 31 sloarly slows that the (rout rajority of the pup 115' (226) fathers wero bors in tho Initod tatos. 34 pupllo huvo fathors who wero horn in issia, 10 hevo fathors who rore lom in foland, and 27

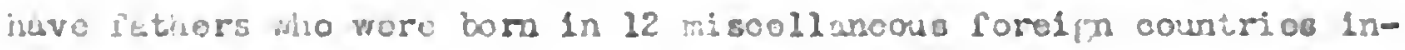

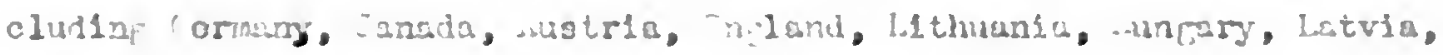
rosco, Grechojlovalt. Buming and urope.

It is eridont tict the distribition 13 havily sicmed to tho rifnt. T.0 \& tost ylolded a valuo of 10.865 for tho rolutionship lotwoun puplle "hooc futierz wore bow in tho initod tatoo and puglls moso fatiors

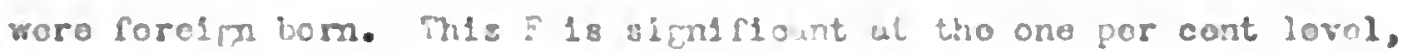
Indionting that thoro is a olalficunt rolutionohip oxistint wotwoen 


\section{Thi L 21}

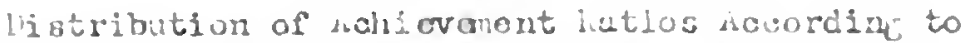

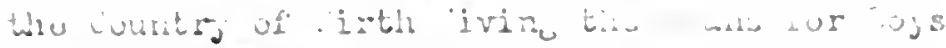
and uirls üeparutoly.

\section{PAIERES COUNTRY OF BIRTE}

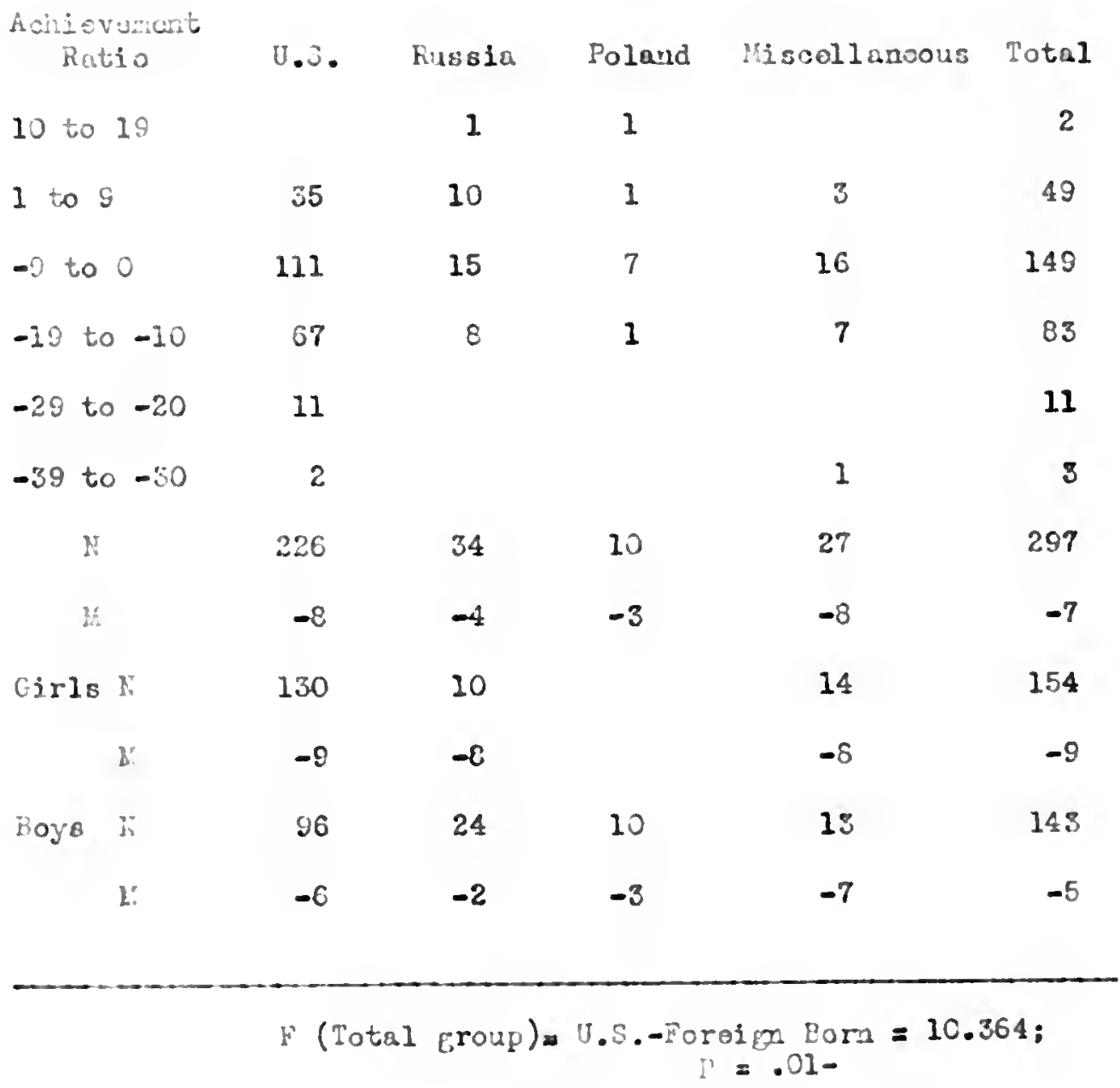





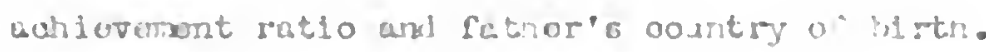

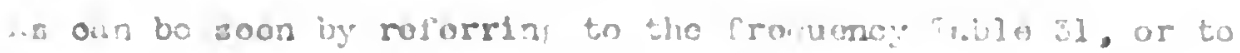
the for, raph in 1pure 17, the puplls whose fatnore voro burn in

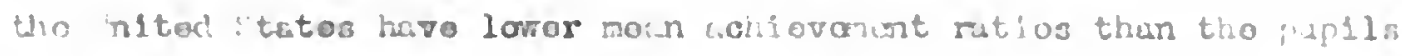

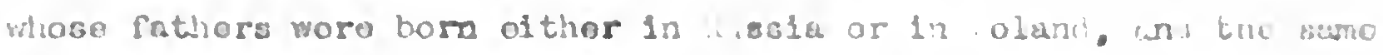
now echievonert mito ae tho miscollanuas froup.

hen tho boy and pris aro comperod, It is form! tist relativoly

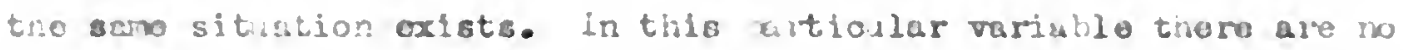

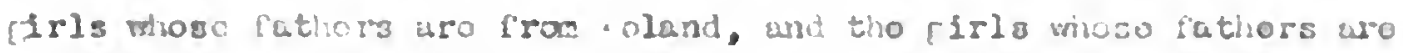

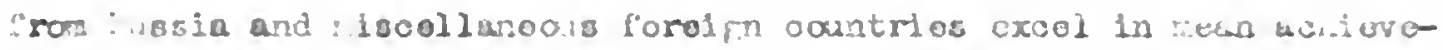

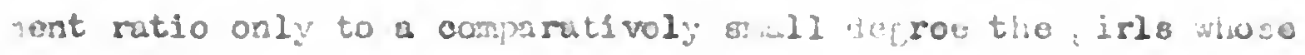
fathors wore kom in the nited. tates. 1310 boys whose futnurs aro

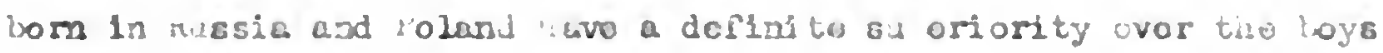

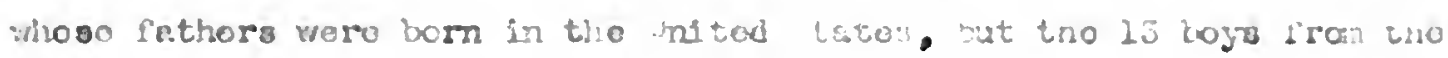
necollanooue forus gn oointries rankod lowor in noun acblove:ont rat lo

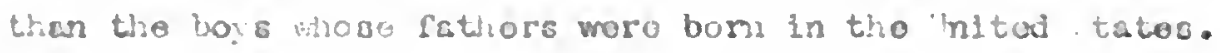

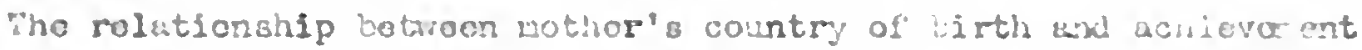

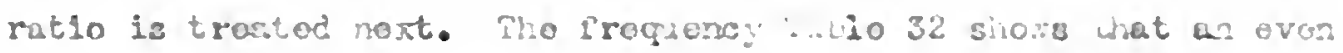
ronter nubar of yuplls bad nothors born in tho inled - tatog than

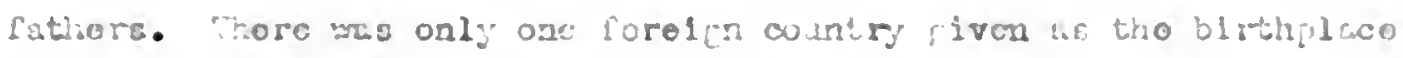

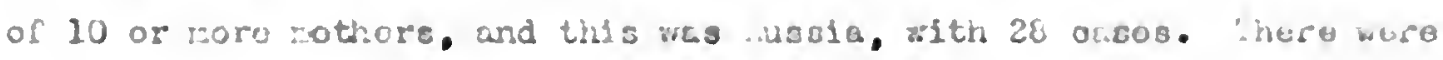

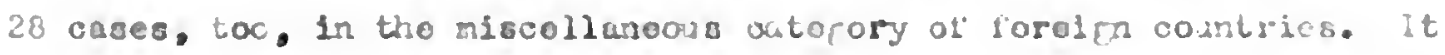

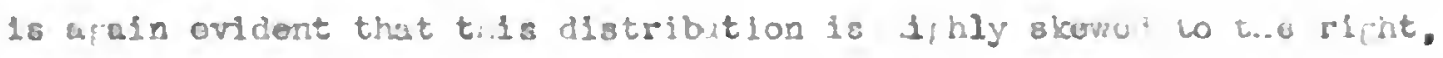
as the r rost rujority of the ousor lisil in ono citucorj.

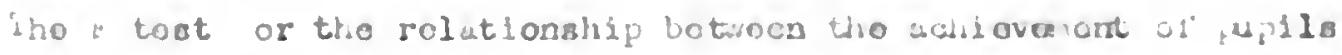

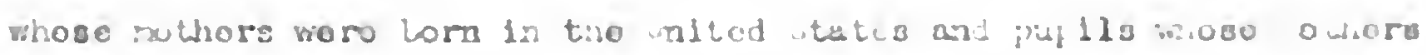

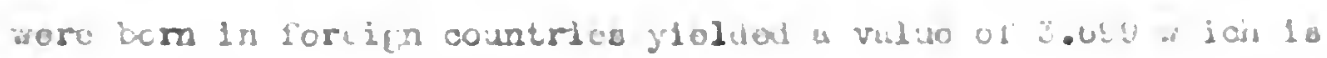





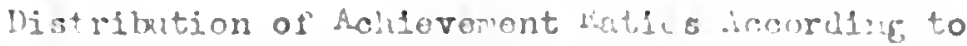

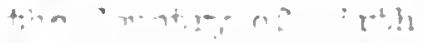

and (1ris Separatoly.

MOTHER'S COATITY OE" BIRTIE

\begin{tabular}{|c|c|c|c|c|c|}
\hline $\begin{array}{l}\text { Achic } \\
\text { Ret }\end{array}$ & $\begin{array}{l}\text { tion. nt. } \\
\text { tio }\end{array}$ & $\begin{array}{l}\text { "nitca } \\
\text { States }\end{array}$ & Russia & $\begin{array}{l}\text { "'iscol- } \\
\text { lensous }\end{array}$ & Total \\
\hline 10 to & 19 & & 1 & 1 & 2 \\
\hline 1 to & & 38 & 6 & 5 & 49 \\
\hline-9 to & 0 & 122 & 12 & 16 & 149 \\
\hline$-12 t$ & $0-10$ & 69 & 8 & 6 & 83 \\
\hline$-29 t$ & $c-20$ & 10 & 1 & & 11 \\
\hline$-39 t$ & $0-30$ & 2 & & 1 & 3 \\
\hline H & & 247 & 28 & 28 & 287 \\
\hline 24 & & -7 & -6 & -6 & -7 \\
\hline Girls & l: & 136 & 7 & 11 & 154 \\
\hline & $\because$ & -8 & -11 & -9 & -9 \\
\hline Boys & $"$ & 105 & 22 & 17 & 143 \\
\hline & $\because$ & -6 & -4 & $-i$ & -5 \\
\hline
\end{tabular}

F (total roup) U.S.-Foreien Born $=3.699 ; r=.(5-$ 
$-$ 


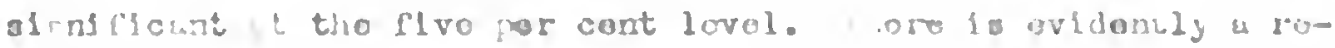

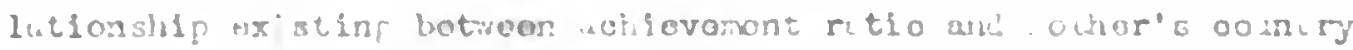
of birth, wit tho rolationship is pot 60 signilount ws that widals cilste lotweor colilevownt sitio und fatior'a soulry ol" blrti.

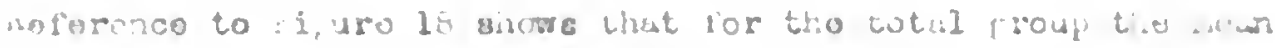

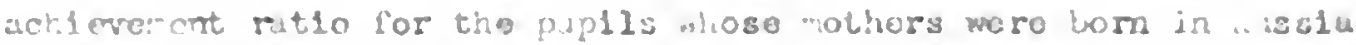

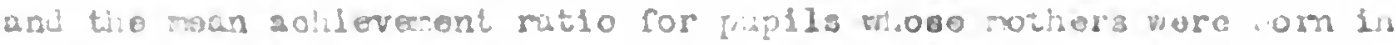

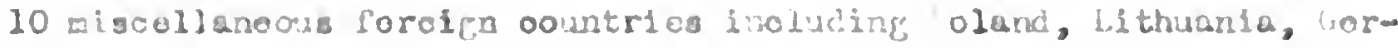
rany, uatrlu, ranco, ryland, ingury, inu'u, zcchosloviria wnd

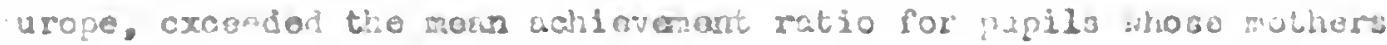
were bors in the justod tatos.

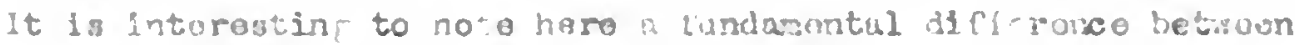
the bog s ard firls. The zen aculeva ont ratio for tivo irls muso

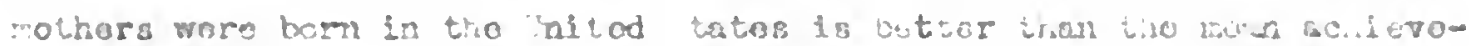

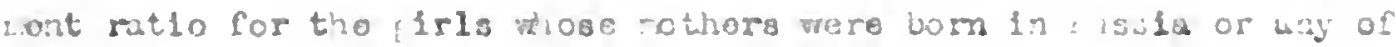

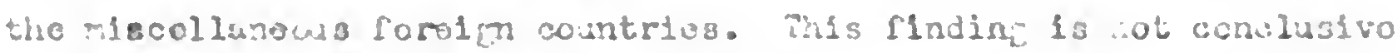

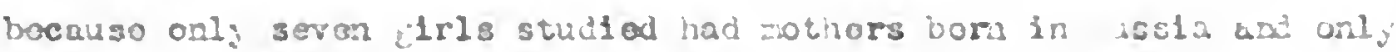
clavan othor firls had rothorg born in othur 10 rulia cowitrles. Mo-

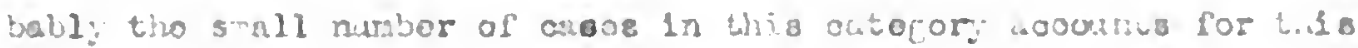
Ulvoriont roleisngibip.

I the othor likad. the man ecinioracent rutio of tho lojs whuso

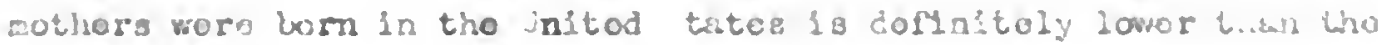

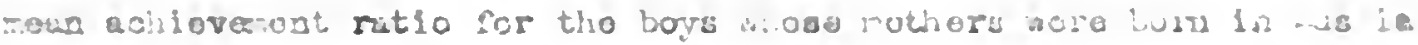
or any of tho Eiscellanoora foraln sountrles. Twunty ond loyo buve Dothors Lom In wasia and sovontoon boyo huvo rothods in nu in ohiser

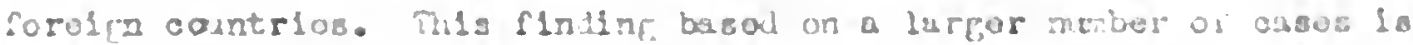
acialn in lino wh wh provioss rosulta. 


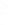


Tho rolationsin hetwoon tho cohievemont ratio and a pupil's fother's fothor's courtry of birth is tirated noxt. Under tis V riable it vas found that thero woro 3 forel po countrias in whioh thero woro 10 or moro casos. The froumency distribution in Tablo 33 was atill heavily skowed to the aicht, but a considerably lurgor numbor of pupils havo nativo born fathers as oompurod to native born paternal Erandfathers. Of tho 226 pupilo whose fathers were bora in the Unitod States, only 151 of theso pupils' patornal frandfathers mere bom in the United States. 46 pupils had patermal Grandfathers born in lusia. 24 hod paternal grandfathors born in uerany, 10 had puternal frundfather: bom in Poland, and 63 had paternal grandfathcrs born in 14 miscellanoous forolgn countrios including Lithuanta, ingland, rustria. Hungary, Latvia, Scotland, Canada, Swoden, France, Holland, Bohomia, Groece, Irel and and Burope.

Tho E test for the relationship betwoen the pupils whoso paternal Erandfathors were born in the Unitod States and the pupils whose puternal erundeathere were borm in foroign countries ylolds a value of 17.703 , which is sifnificant at the one per cont level. Thore is a significant rolationship oxisting betwoon achiovenut ratio and fathor's father's country of bith.

figre 19 shows again the superiority of pupils who luve forelgh born antecodents as compared to puplls whose antocedonts are nativo bom. In every category of pupils with forolpa bom patemal enanfathors, the noan achievonont ratio is frouter than it is for the pupils who have paternal grandratherg born in the Unitod statos. It is interosting to noto that tho pupils whose patemal prund futhors cono from 


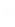




\section{This 33}

Distribution of Achiovamont Ratios Aucording, to the Fathor's Futhor's dountry of 'irth Civine the ileans for Boys and Girls Separately.

\section{FATIER'S FATIER'S COUNTRY OF BIRTII}

\begin{tabular}{|c|c|c|c|c|c|c|c|}
\hline \multicolumn{2}{|c|}{ Aohievomont } & U.S, & Russia & Gormany & Poland & Misoellaneous & Total \\
\hline 10 to & 19 & & 1 & & 1 & & \\
\hline 1 to & & 20 & 10 & 5 & 2 & 12 & 4 \\
\hline-9 to & 0 & 75 & 19 & 18 & 6 & 31 & 1 \\
\hline-12 to & -10 & 48 & 15 & 1 & 1 & 18 & \\
\hline$-29 t$ & $=0-20$ & 9 & 1 & & & 1 & \\
\hline$-39 t$ & to -30 & 2 & & & & 1 & \\
\hline$y$ & & 154 & 46 & 24 & 10 & 63 & 25 \\
\hline 4 & & -8 & -6 & -3 & -2 & -7 & \\
\hline Girls & $\mathrm{N}$ & 103 & 15 & 11 & 1 & 24 & $1:$ \\
\hline & $2:$ & -9 & -9 & -2 & t5 & -9 & \\
\hline Boys & $N$ & 51 & 31 & 13 & 9 & 39 & 1 \\
\hline & $M$ & -7 & -4 & -5 & -3 & -5 & \\
\hline
\end{tabular}

$F($ total group $)=17.703 ; 1=.01-$ 
. 

$\therefore \because$,

$i^{2}$

$\because$

- $\begin{gathered}4 \\ -34\end{gathered}$

? 


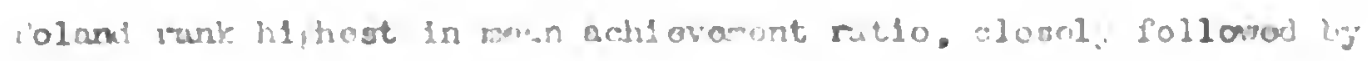
paptle wioso; atemis randetiore oase from lorany, then iresiu. thon misollunocua, axd finaliy last. Nith tho lovopt peur achioversont

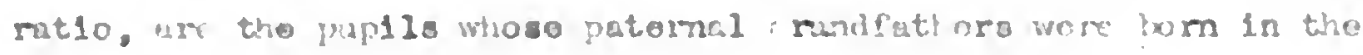
initerl tatos.

ithout guostion hich achiovarent ritio is afuin aseosid tad

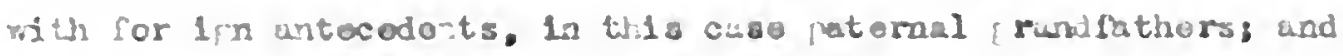
lur cohicveront retio is associthed with notive bora patomal rundpathers.

The sume rolationship that bolds lor tho total group holde for ho boys oniy. ... bin tho kojs whove putemal rundfuthors ara fras thic nitod tatos aro lowost in man achiovorart rutio. tho nisooll-

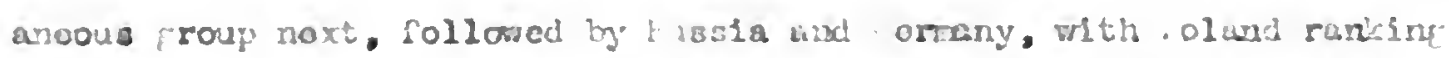
hil hest as tho coutr. havin tho frutomal randfathore of pupila rhose soun acllevesant ratlo is hiphest.

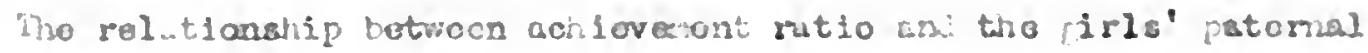
rundeluore' country of birth fluctuatos considerably. 103 firls whose patomal fronifathars cano prom tho inftod tates and 15 firls whooo

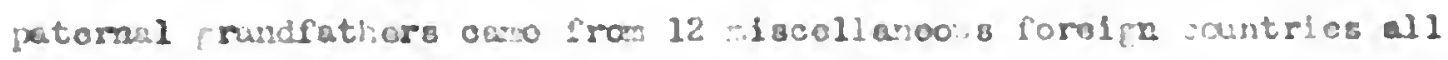
Pivo tho saro mean adiloveront ratio. Fpo 11 , irls rhoso patomal

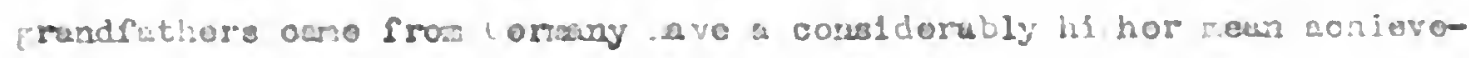
mont rutlo than any of the 2 proups fust ranticad, but those puplis in

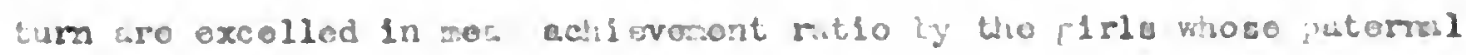
rrualfaticrs sore born in ioland.

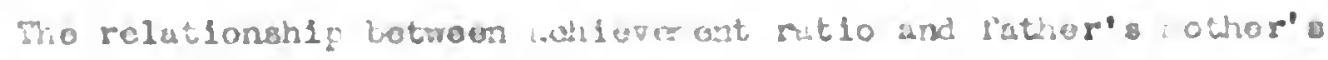

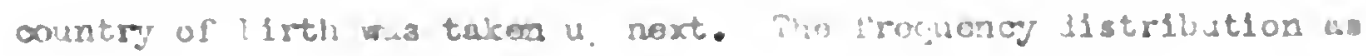





\section{T.'.1: 4}

Distrinition of Achioromat Rutios uccominm to

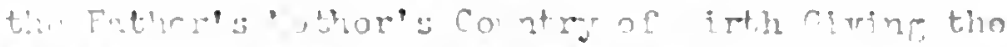

Heans for Boys and Girls Soparatoly.

\section{FATHIR'S IOTITR'S COUNTRY OF BIRTH}

Aciliavincolt

Tratio U.S. Russia Germany Poland Hisoellanoous Total

10 to 19

1

1

2

1 to

20

9

6

2

12

49

-9 to 0

78

18

17

7

29

149

-18 to -10

$49 \quad 14$

1

19

83

-39 to -20

1

1

11

-39 to -30

2

1

3

\begin{tabular}{|c|c|c|c|c|c|c|c|}
\hline & I & 158 & 43 & 23 & 11 & 62 & 297 \\
\hline & $u$ & -8 & -6 & -2 & -2 & -7 & -7 \\
\hline Girls & $\mathrm{li}$ & 106 & 11 & 15 & 1 & 21 & 154 \\
\hline & li: & -9 & -2 & -9 & $\not 5$ & -11 & -9 \\
\hline Boys & $\mathrm{N}$ & 52 & 12 & 28 & 10 & 41 & 143 \\
\hline & b' & -7 & -3 & -4 & -3 & -5 & -5 \\
\hline
\end{tabular}

F (total erovis)

$=20.746$ 
show in $i$ iblo 3418 aruin skerrod to tho rifht as a roil at of tho refority of ousos falline in tho outorory of puplis whoso patornul Frund-othors woro born in tho Jnitod itatos. 158 pupils huvo nim tivo tom putomal, rabdsothora, 43 piplis huvo patomul prundiothore tom in Russ10, 23 have putomul prindzothora born in orrang. 11 have patomal randmothors born in oland and G2 havo patornal fundrothurs borm in $12 \mathrm{misoclancos}$ forolgn oountrlos Including Canada, :unfary,

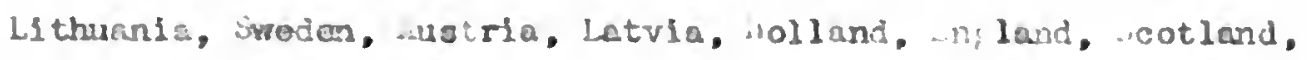
Ehanla cronce and lie rway.

Tho E tost for tlie rolitionship betroen achiovonont rit 10 and father's mother's country 6 birth yioliod a valuo of 20.746 wiloh was simifleant at the ono por cont levol. . 31 al fioant rolation-

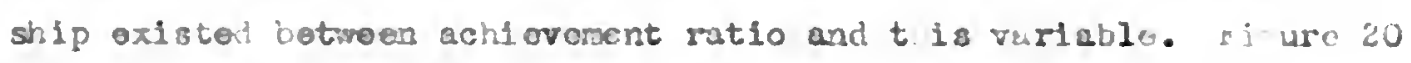
shows tiat apuin his achiovoment rutio was asaoci tod with forolf cosity of tirth.

"iho swo consistent relationshlp betwosn acilovornant rutio and anteoodats' courtry of birth hald for thio variable as in tho procodine ones. Uplis vith native korn patorial prandmotiors runicod

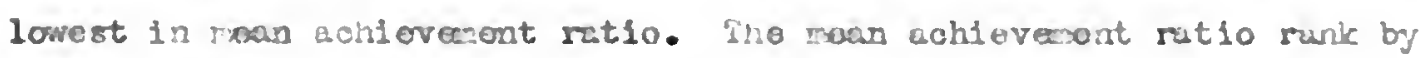
countries ra inltad tates lowost, wis00110re018 noxt, followod by Muscia, mth vamany and iolend tiod for top pouston.

iluro 20 sinows that, wth one rinor excoption, the rresn achleremont ratlos for tho boys malntalas the olno rolutive rolutionship to

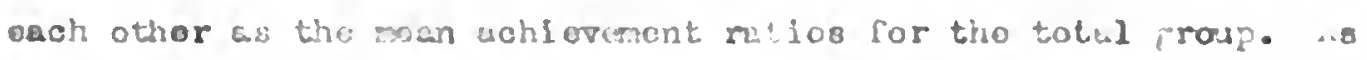
bofore, the intind itatos ranks lowest in moun acklo:osont ratio,

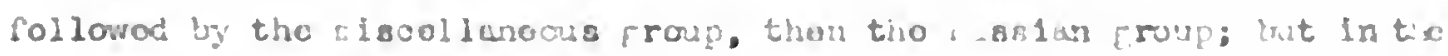

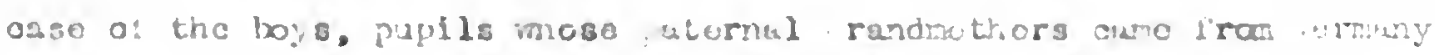



- 


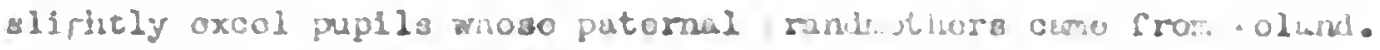

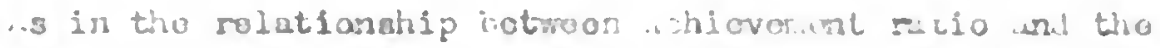

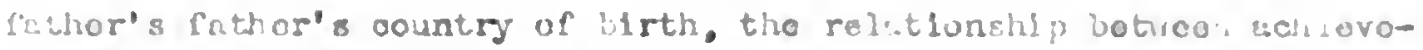
Font ratio ari fathor'a mothor's country of listh for isrle only

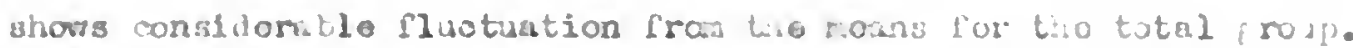

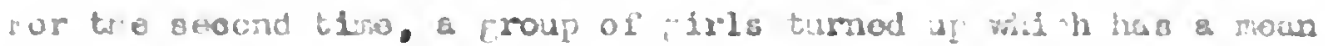

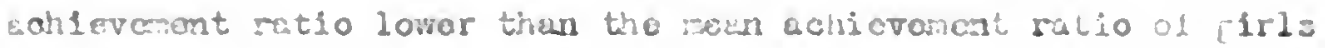
whose artooodents auro irom tro nitad "tatos. In this cusc it is

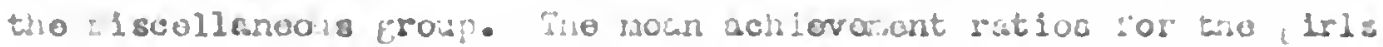
rinkod by cautries aro as followa miscollunciis, nitod twos

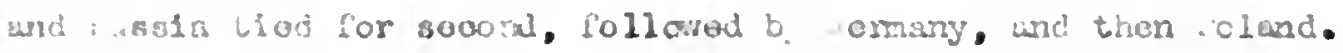

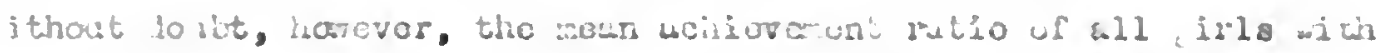

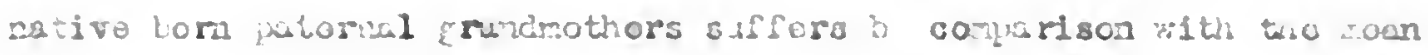

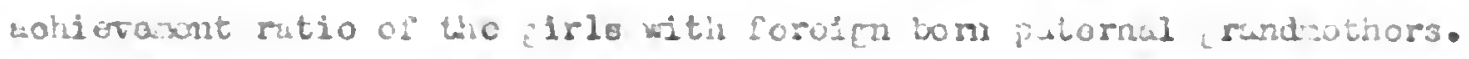
The relutionship of cel.icvonont ritio to rothor' a iatior' a countr.

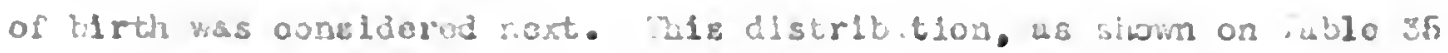

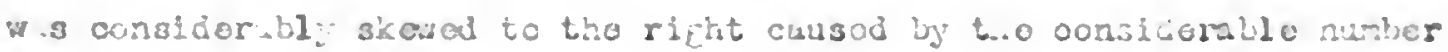
of puple (161) shoso ratoral f ruarelicrs woro win in lia initod

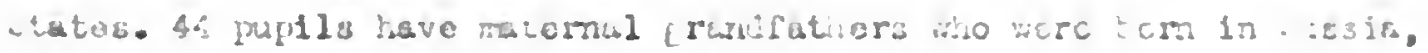

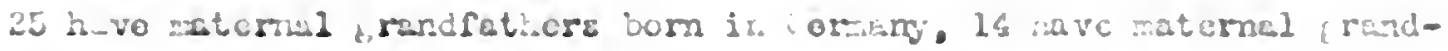
Sathore born in - oland, and 63 hevo matornal fandetions bost in 12

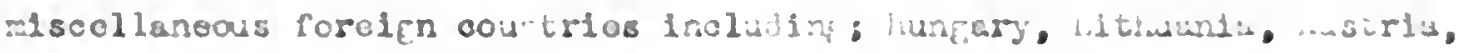

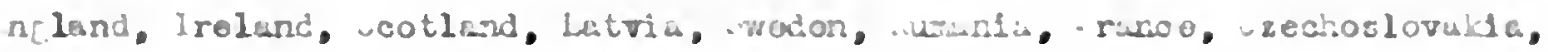
and pain.

Who test for tho rolutionailp Lotwoun tho papils wosu tatoral 


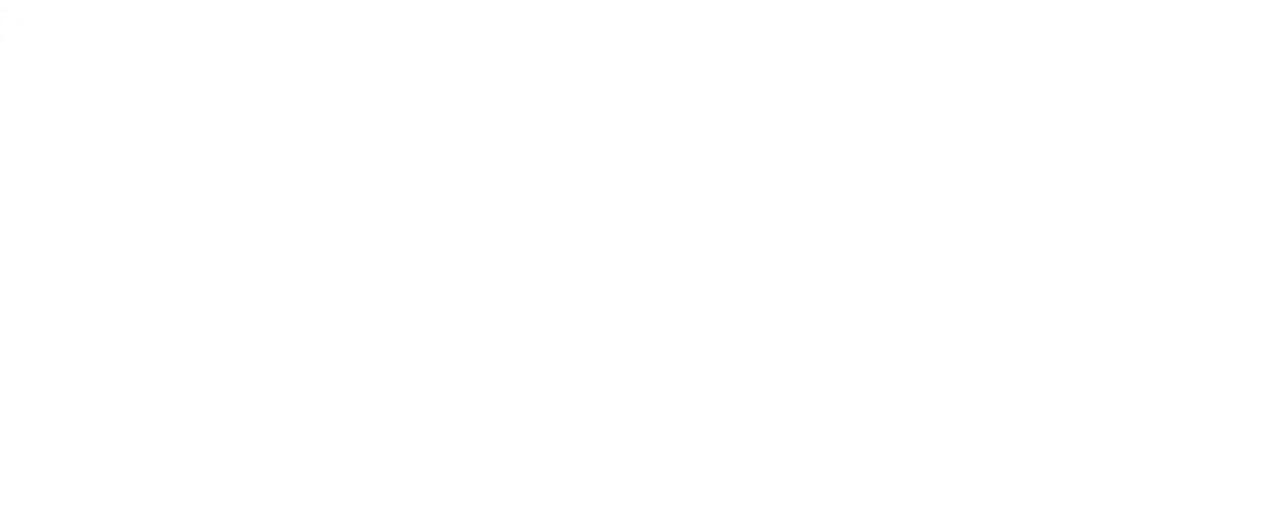




\section{TAL 35}

Distrivation of Acilievanont Tatios haorlln to the Lother's Fatior's Country of Birth Giving

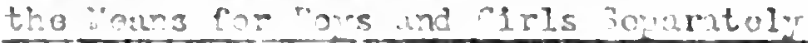

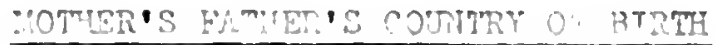

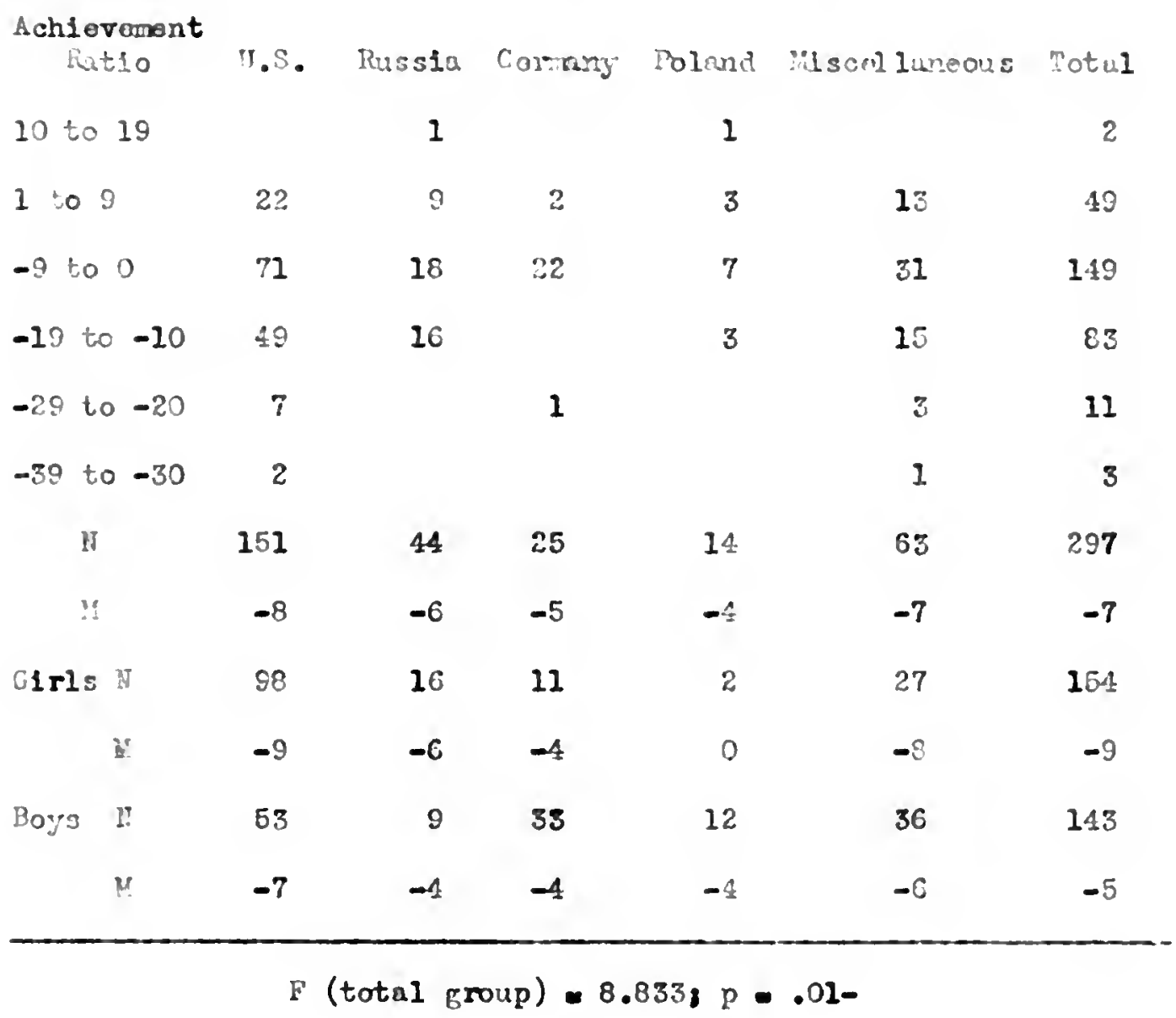







\section{TABLE. 36}

Ds at ripution of Achiovonnt Ratios konorlin to tho bother'g hother' Country of 31 rth sivine tho bioans for roys and lirls Sepamtely.

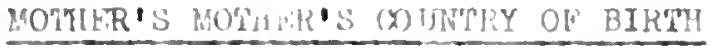

Aahievanont

Ratio

U.S. Russia Germany Poland Miscollanoous Totul

10 to 19

1

1

2

1 to 9

$17 \quad 10$

$?$

17

49

-9 to 0

75

20

21

2.5

119

-19 to -10

46

15

2

3

17

83

-29 to -20

7

1

11

-39 to -30

3

3

\begin{tabular}{ccccccc}
$M$ & 147 & 46 & 26 & 14 & 64 & 297 \\
Girls & -8 & -6 & -6 & -5 & -6 & -7 \\
Boys $N$ & 97 & 11 & 13 & 3 & 30 & 151 \\
& -9 & -4 & -7 & -2 & -7 & -9 \\
& 50 & 35 & 13 & 11 & -4 & -5 \\
\hline & -7 & -4 & -4 & -6 & -6 & -63
\end{tabular}


. 


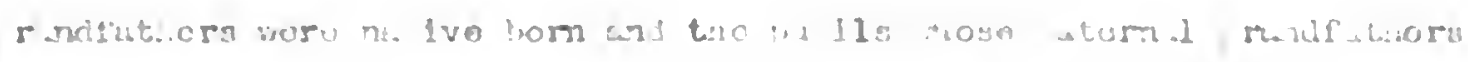

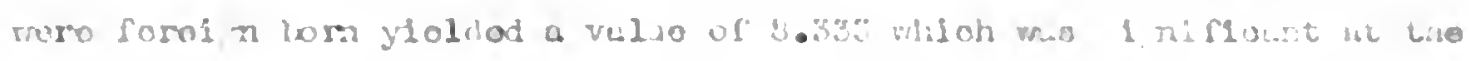

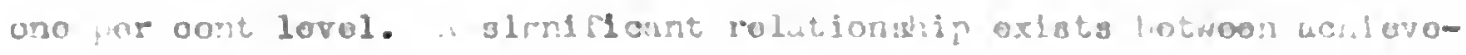

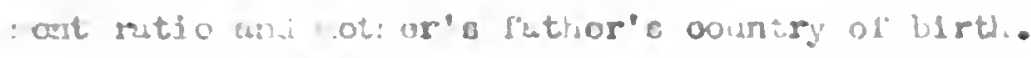

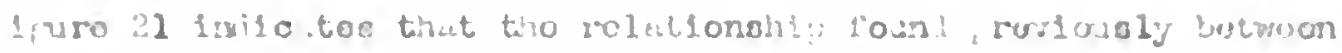

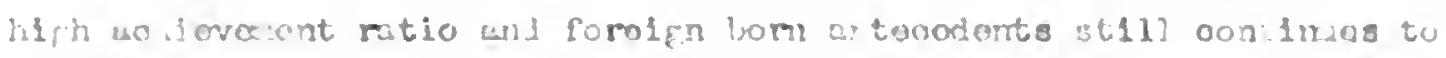

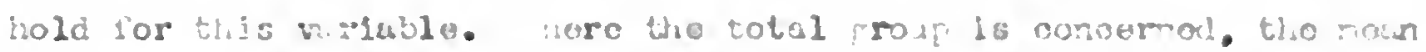

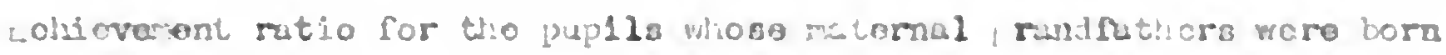

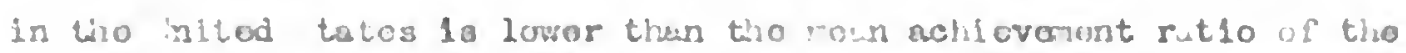

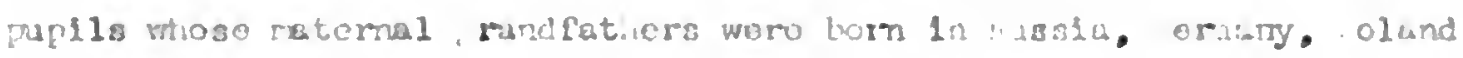
or the riscoilureos froup of forciph oountrios.

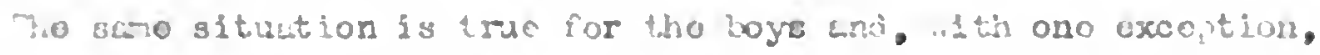

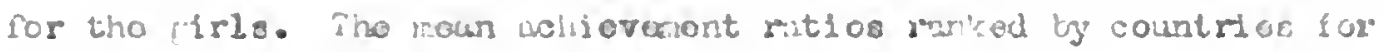
woys, firla knd the total croup 10 ar folldwa: ar tho bogs- ind tod

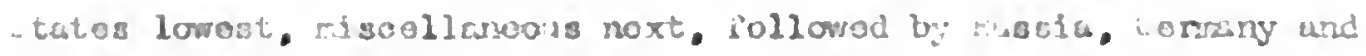

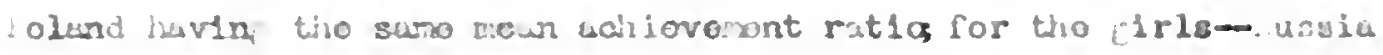
lasest, initod tatos noxt. followed by mideollancour. or ang wal - oland ior tho totil roup- inited titos lovost, iscollingeose

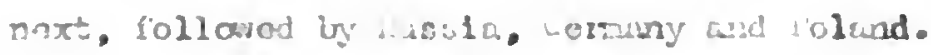

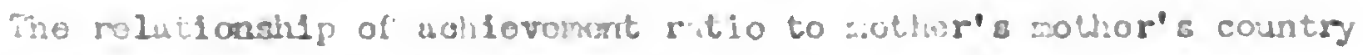
of tirth we the nort veriablo oonoldera:. ?aln 36 shows tho distri-

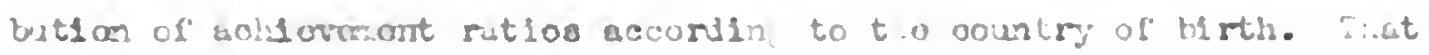

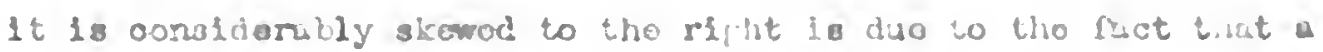

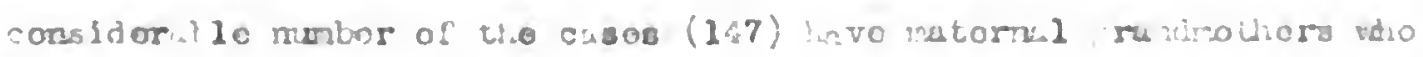
wore born in the nicod tatos. SC pullls luve plomel, runirouhore

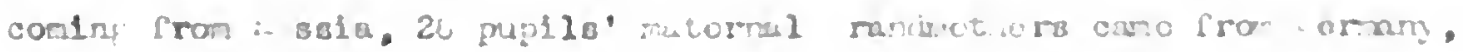


. 


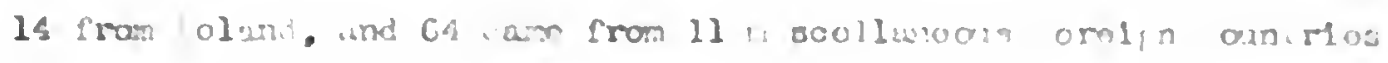

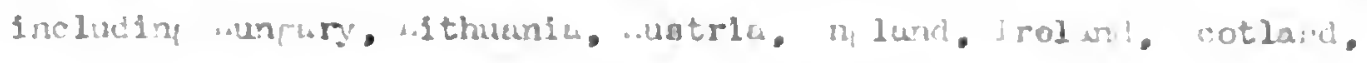

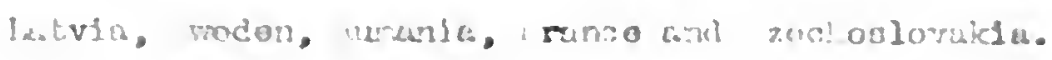

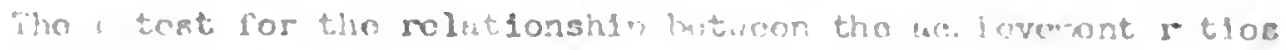
of pupils whose: atomal, na imotiore woro born in the nitod catso

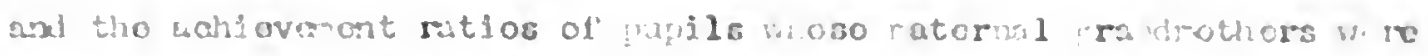

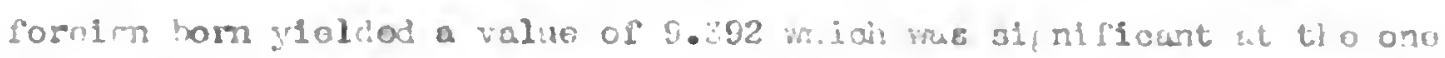

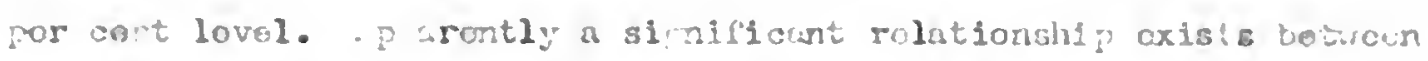
wehlevercht ritio and Uie ratornol reandiothor's country of birth. ifaro 22 ladicutos that .. ICll acisovement rutio 13 a wia associnter with foroin born antecodonts. Tho Jorn liciliovanont rutio

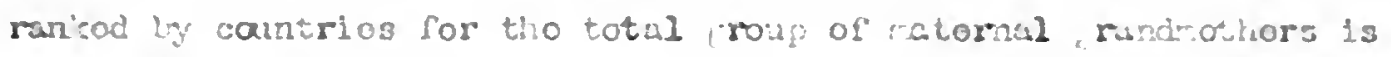

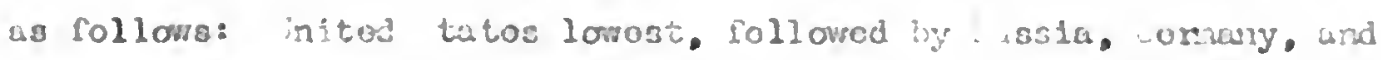
the riscellanoas lorolin co.ntrics all with the sumo roun nchiovonut rutio, Htir iolund aving, tho hiphost torn uchevonont rutio. hon tho bogs aro oonstdcred 30 proratoly. whe savo rulutionship botwean achiovemect nitio and antocodents' country of Uirth holdo poos with very littlo Rluctution. In ovory ense hin boys whoso ratormal rundrothors cere from tive nitod tribos rans lowor in roan achiovo-

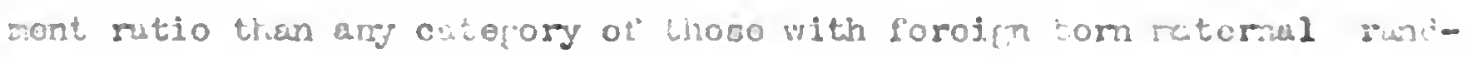
rothere. : iruro 22 continas to shor consicorublo rluot wation in ihe goan achiovenont rutios of elrls havin lorcign bom -atemal randrotiore.

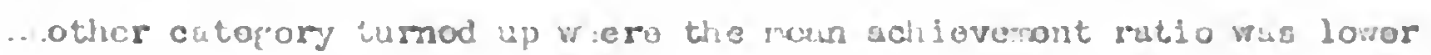

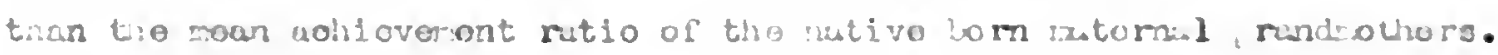

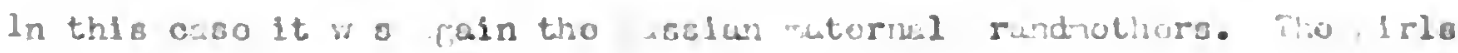

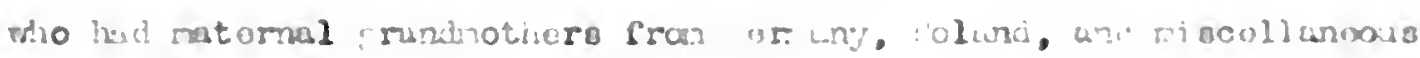

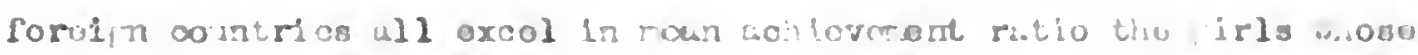
ratomal raztrothors woro lom in tho nitud tatos. 



\section{Jux=ary}

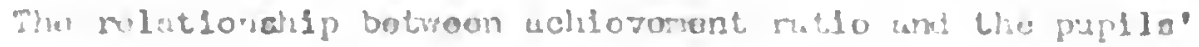

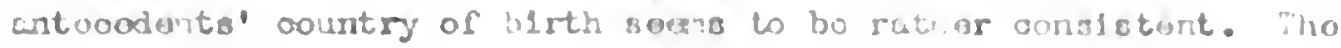

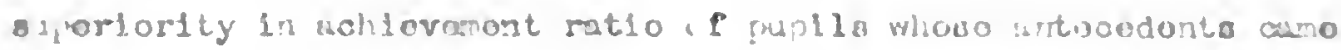

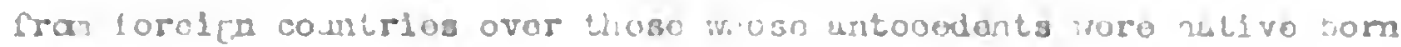

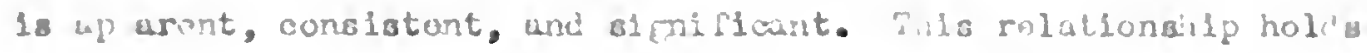

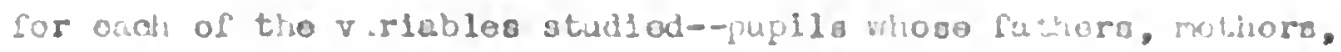

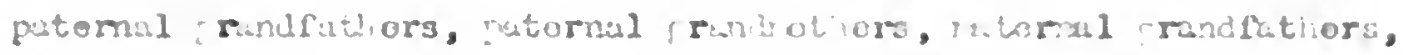
and ratornal rand othoro wore bom in foralin countriog aro ruro

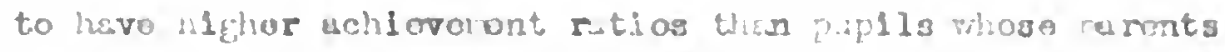
und rundparonto voro born in tio int tod tatos.

Theso Mndings aro in arrocront with inno of . osincles and

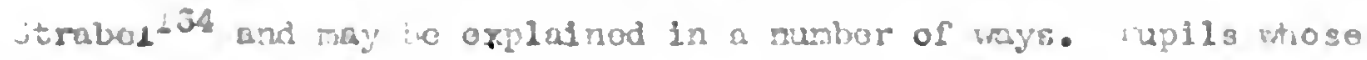
estocodonts woro poroign vom are moro lihely to axand foro oflort

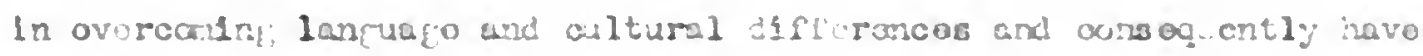

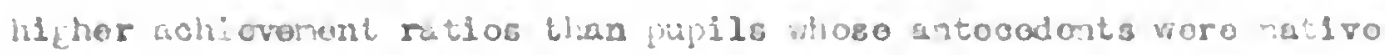

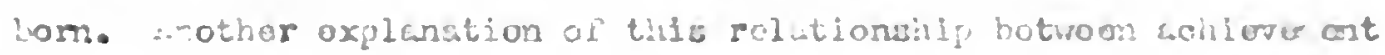
ratio and the forolon born antocodent: of si crlor fupila zay be that those pup11s hevint forolph lom antocodonto edo t.cro litoly to up ro-

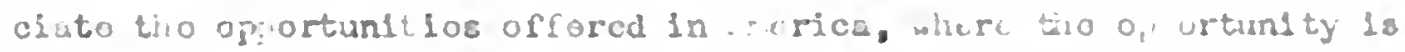

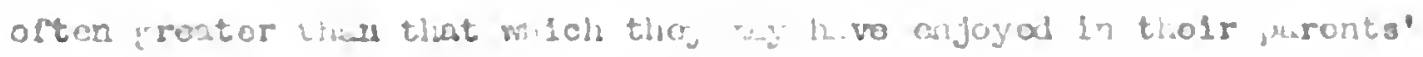

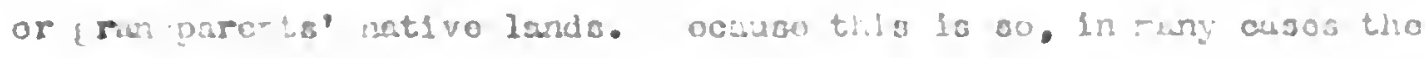

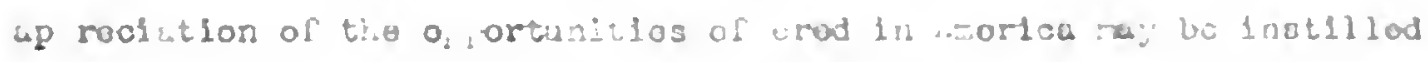
in tiso pugll by his foralcz tom prent or rusurant whi so notivuto h1: to roctor cohiova cnt. 

The rolution of Aclilovoment netlo to suthor's duation

Wata was collootod on the rount of formal adiuntion confoyors by tho father of aad pupll studiod. Thlo 37 shows that 59 fallora had

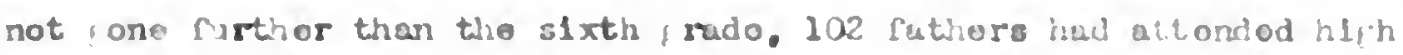
Gohool without graduating, 28 had produatod from hich sohool. 12 had attontad oolloge without Eraduatin. and 40 had pradutod fror collogo. In 56 asos Infomation ws incorplete refardin? the adication of tho fathoro. Tho alstribution is skased to tho right, Mth tio modian liallInf in the attonded but did not eraluate from hich ochool autofory.

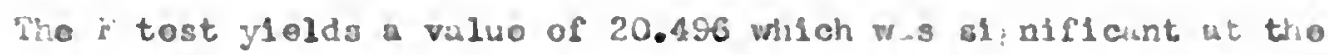

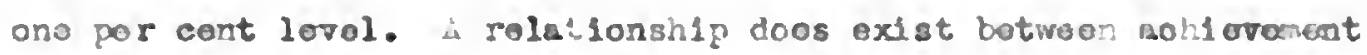
rutio and tho emount of fathor's oducction; and this relationaing is sinlricant.

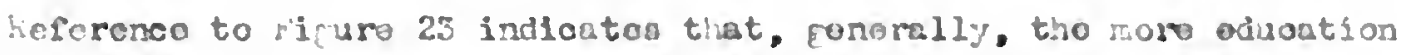
tho ithor has. tho hichor tho achiovament nitio of tho pupll. Its trma is farticulsrly ovldent, with ono oxcoption. Tho pluplis viloso fathors attondod colloge tat did rot fraduato, drop in aohlovonont retlo a triflo below thic puils whoso iathors had raduatod from hith school. Pooullarly enouph, the puplls whace rathors' aduostion vas unicown ranic a trifle move tho noan for tho total rusp in tho distrib tion. hen tho relutionship betwoen tho fathor's odiortion and aohloro-

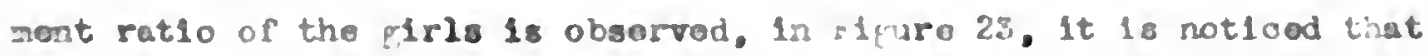
tho semo fonorel trond hold truo - tho noro adusetion tho plria' fachere had. tho hifhor the [1rle' wohlevount rutio. Fhoro io ono oxooption to this. Tho cirlo whoso fathers had f radiated frue collopo rank a trigle bolon loth the pirla whoce fathors had frudiated frot ilch sohool 



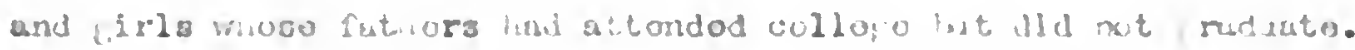

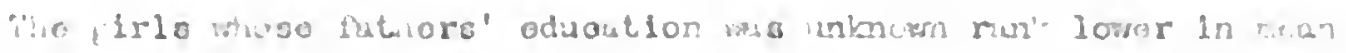

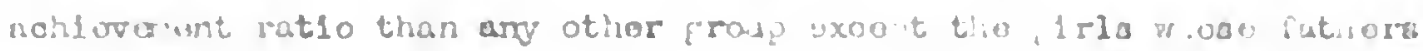
had attondod elenent ry ochool.

The rolationahip botween tho achiovment ratio and tin Lo. 3 '

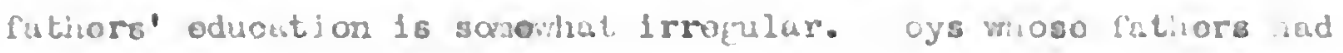

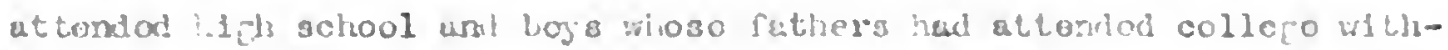

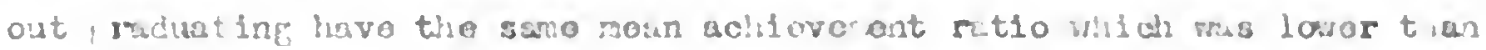

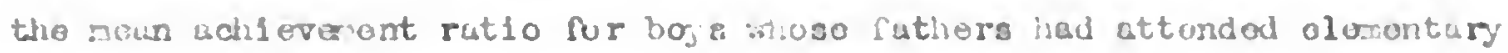

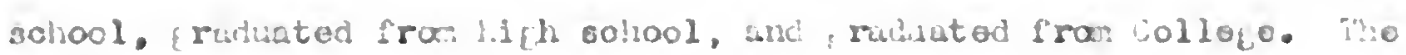

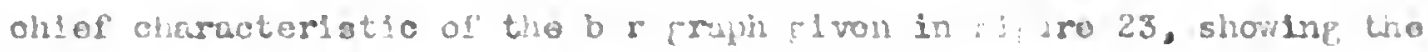
rolutionahp batwcan uchicronunt ratio and futror'o aducition is tho prost arant of sliotiation.

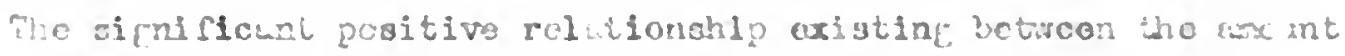
of oducition of a pupl's father and his sohiovor ant sutio rä bo accoutod for in a numbr of mys. It is c: 160 poosiblo that b juril whose fathor 1 a bottor oducatod w11 be bettor ablo to holp rit with his school work. knd this risy reasit in 2 ill hor uchicvonont nitlo for tho mp11. uplls are rore likcly to roonoct sus look up to paronts wio wro bottor adjostad, und consaquontly strivo sardor to ancood in their scho 1 rork in orier to be rore like thoir. aronts. arunto who havo i ttur oducation $\nabla$ ry citon ap reolute its raluo and therefore onodrufo their ofleprin" to work harier in school be lut thoy, too, sicy rooolvo a rood o Eeriupe who fuct thet tho puplla whoso futhors ultonded collic o lut did not prasuto ilave a lower noun aobirvoront rutio $t$ an tio palls

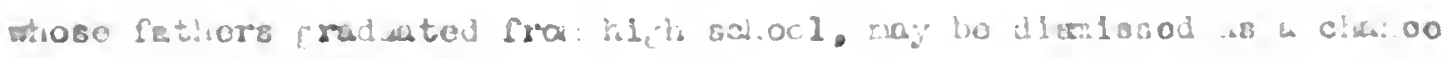



orror, ar tidg 118 orenoo 18 rathor all.

Fho differonoo botivoon tho rolulionglip of tho cons swonont ratio

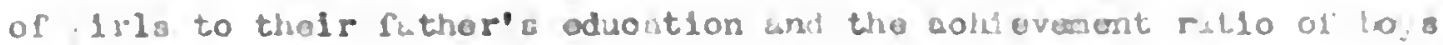

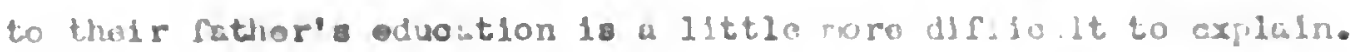

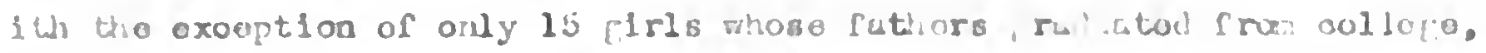

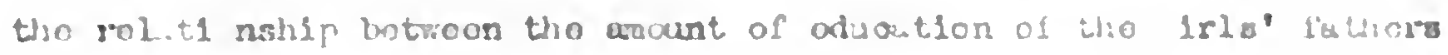

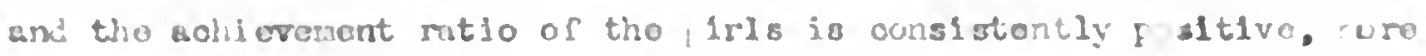
so for tho firlo than for tho totil proup. oriaps tho proator influono of tho Rathor's educistion on the firlo' achlevasont rutio ray

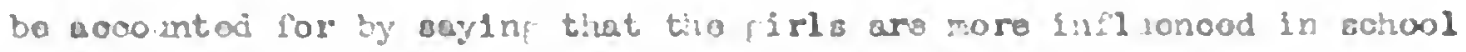
ratters $b$ tholr fathers lhas aro boyo.

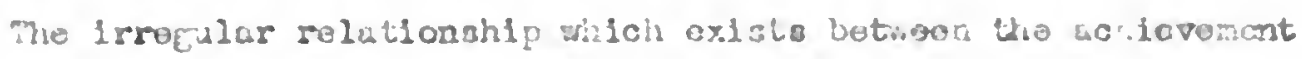
rillo of tho boyo and wholr father's clucution soars to irrisouta that tho byo are holpod and ancouracod rach loes by thal iathors thun wro the frls. Thare ray do a compensuting caubo for this il.otiation in tho rolitianshe for this varloblo. It io possiblo tiut tio loys, soolne

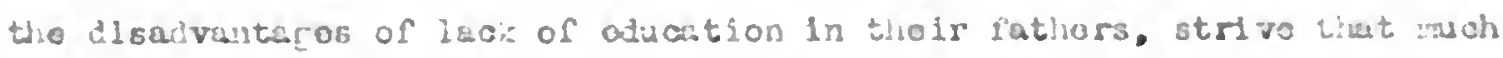
harder to acquiro an eduoution for thorgolvec. This may account for tho fect thut tho boys wose futhere had attondod only elcmontirn ochool ox-

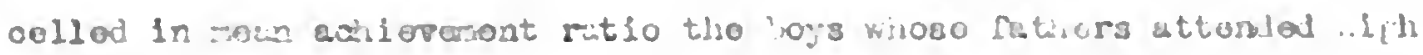
cohool and bojo whose fathors attondod collace. It loos rut, horover, account for tha faot that boys whose rathers pradutad frac $121 \mathrm{~h}$ school and oollefo oxvollod In sesn achlevenont ratio tho boyt whoso fishors

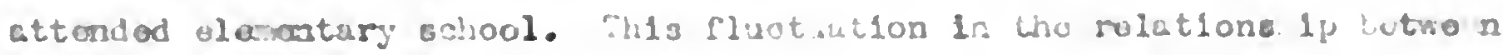
collovacant rut1o and to B' futturs' od ication iz bo as uccuntod for If who fuot that thoro aro crly 16 boyt whoso lathors wetesidod ale ont ry

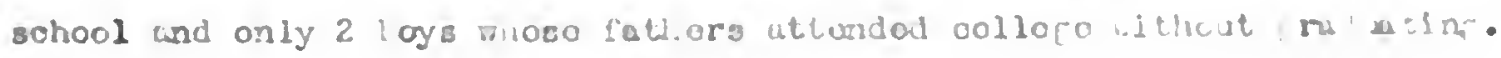





\section{T:BLE 37}

Distribution of Mohlovemont Ratios Acoording to

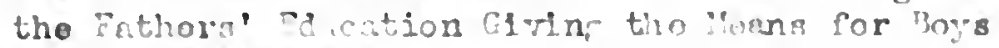
and Girls Soparately.

\section{FATHEXS' EDUCATION}

\begin{tabular}{|c|c|c|c|c|c|c|c|c|}
\hline \multicolumn{2}{|c|}{$\begin{array}{l}\text { Aohiovamant } \\
\text { Ratio }\end{array}$} & \multirow[t]{2}{*}{ Elcmentary } & $\begin{array}{l}\text { Attordod } \\
\text { hilgh } \\
\text { School }\end{array}$ & $\begin{array}{l}\text { H.S. } \\
\text { crnd. }\end{array}$ & College & $\begin{array}{l}\text { Coll. } \\
\text { Grad. }\end{array}$ & $\begin{array}{l}\text { Un- } \\
\text { knom }\end{array}$ & Total \\
\hline 10 to & 19 & & & 1 & & 1 & & 2 \\
\hline 1 to s & & 3 & 18 & 9 & 2 & 9 & 13 & 49 \\
\hline-9 to & 0 & 16 & 51 & 31 & 7 & 21 & 23 & 149 \\
\hline-19 to & $0-10$ & 15 & 35 & 5 & 3 & 7 & 18 & 83 \\
\hline-29 to & $0-20$ & 4 & 2 & 1 & & 2 & 2. & 11 \\
\hline$-39 t c$ & $0-30$ & 1 & 1 & 1 & & & & 3 \\
\hline $\mathbb{N}$ & & 39 & 102 & 48 & 12 & 40 & 56 & 297 \\
\hline$y$ & & -11 & -8 & -6 & -6 & -5 & -7 & -7 \\
\hline Cirle & iv & 23 & 53 & 31 & 9 & $2:$ & 15 & $10 \mathrm{~s}$ \\
\hline & $\mathbf{W}$ & -15 & -8 & -6 & -5 & -7 & -11 & -9 \\
\hline Boys & ii & 16 & 49 & 17 & 3 & 17 & 31 & 14.3 \\
\hline & $u$ & -4 & -8 & -3 & -8 & -2 & -5 & -5 \\
\hline
\end{tabular}

$F($ total group $)=20.493 ; p=.01-$ 



The sirul numbor of cuses in thoso two cutcliorlos make the moan uchiovomant rutio for tho 2 ontugorius unroliublo. Thusu findine aro in gonoril agroemant with thoso of Dougluse and Cumplial1 165. Clark ${ }^{166}$, Smith ${ }^{167}$, and Dosing ${ }^{168}$, howevor, find a norativo rolation botweon pupils' nohiovomont and tho futhors' oduontion. Furlaps tho disagroamont existing may result from tho proator influonco of fathors' aduortion on Girls than on boys.

The Rolation of Achievament Ratio to Mothor's Education

The forml education received by tho mothers of tho suporior pupile studiet rantes from attondance to elementary sohool through graduation from colloge.

The distribution of achievement ratios of the pupils acoording to the amount of educution rocoivod by their mothors shown in Tablo 58 is skered to the loft with the mean education of the mothers falling in the attended but did not graduato fram high school oatogory. In 46 cases of the 297 studied, the extent of the mothor's education is not given. The distributions for the boys and Girls $4 \cdot 293$ itt 16 in this respoot from that for tho total Eroup.

Tho F test for analyois of varianco yleldod a valuo of 12.248 which, when the degreos of froodor are considared, is slinilleant at the one por cant levol, making, tho null hypothosis untonable. A sienlficant rolation vory likely odsts botwoon achiovement ratio and tho amount of mother's education.

165 Douglass, Harl h. and Camptoll, Ina, op. olt. pp. 188-189.

166 Clark, E. L., op. cit. p. 237.

167 Suth, harry p.. op. olt. p. 27.

168 Dosing. Minerva f., op. olt. p. 107. 



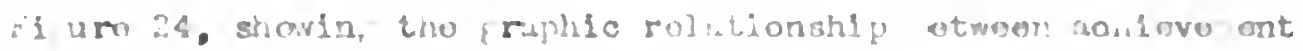

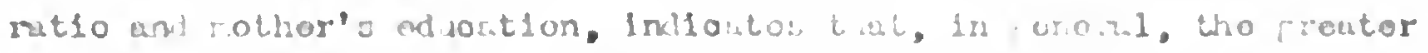

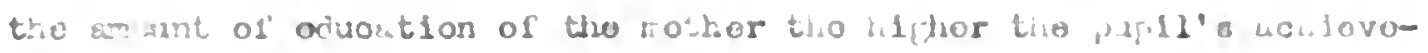

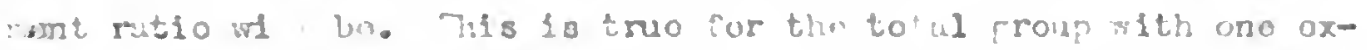

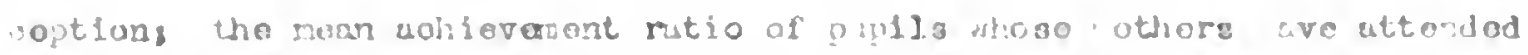
only closentary sabool is protor thun tho no:n achiovosunt ritio of tho pupila whose notiors havo uttendod hich school, ani oguals that of tho hich sohool tratusto roup.

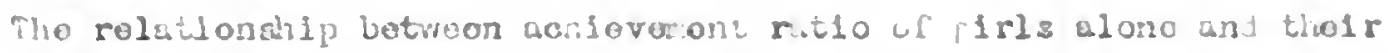
rothor's oducution 12 moro pronounood tibn it is lor tho toul roup.

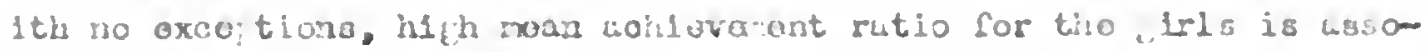

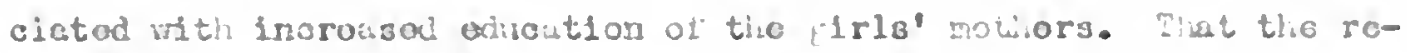
lution oxisting horo 18 vory consiotont is shom in frure 24.

sor tho boys. L oro is litilo ralstion botwoon dollovosiant rutio and motinor's oduo.t1on, as shom 1n. íuro 24. nly two of tito c tor porles hiso noan sciblovecnt rutios that viry ut all from tho wan for

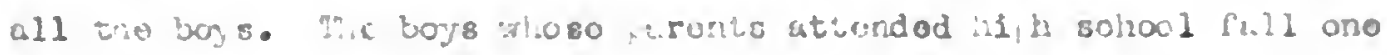

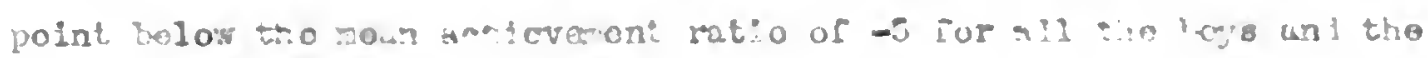

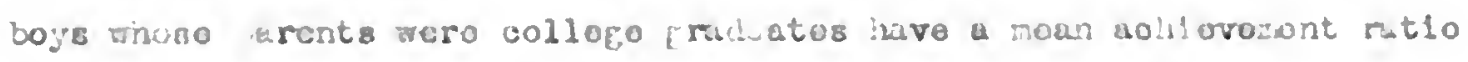
two points abovo the roma. "ise rolution of lor aokievcust ratio isth

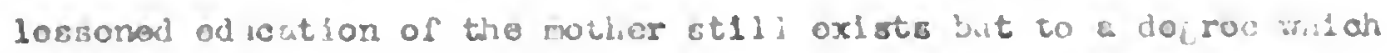
was no lonser slinifichrst.

'tho rolation botroon rupils' weitiovo cot riblos und tholr rotidor's

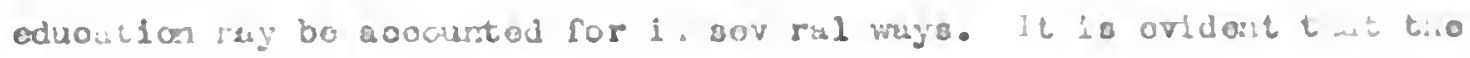
exptinf rcluliondilp is duo onlorly to wio frlo sxt not tho boys.

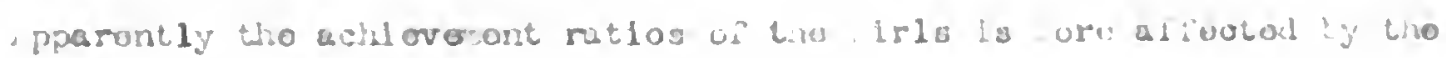
anount of thoir "olior's od.cution tian lo tho ac iovo ant riotlo of 



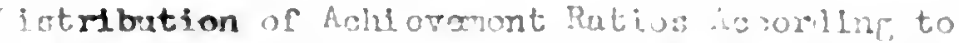
tho Lot? w. "lucution Givine, the Wens for Boys

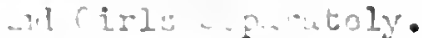

\section{MOMIERS' EDTCATOR}

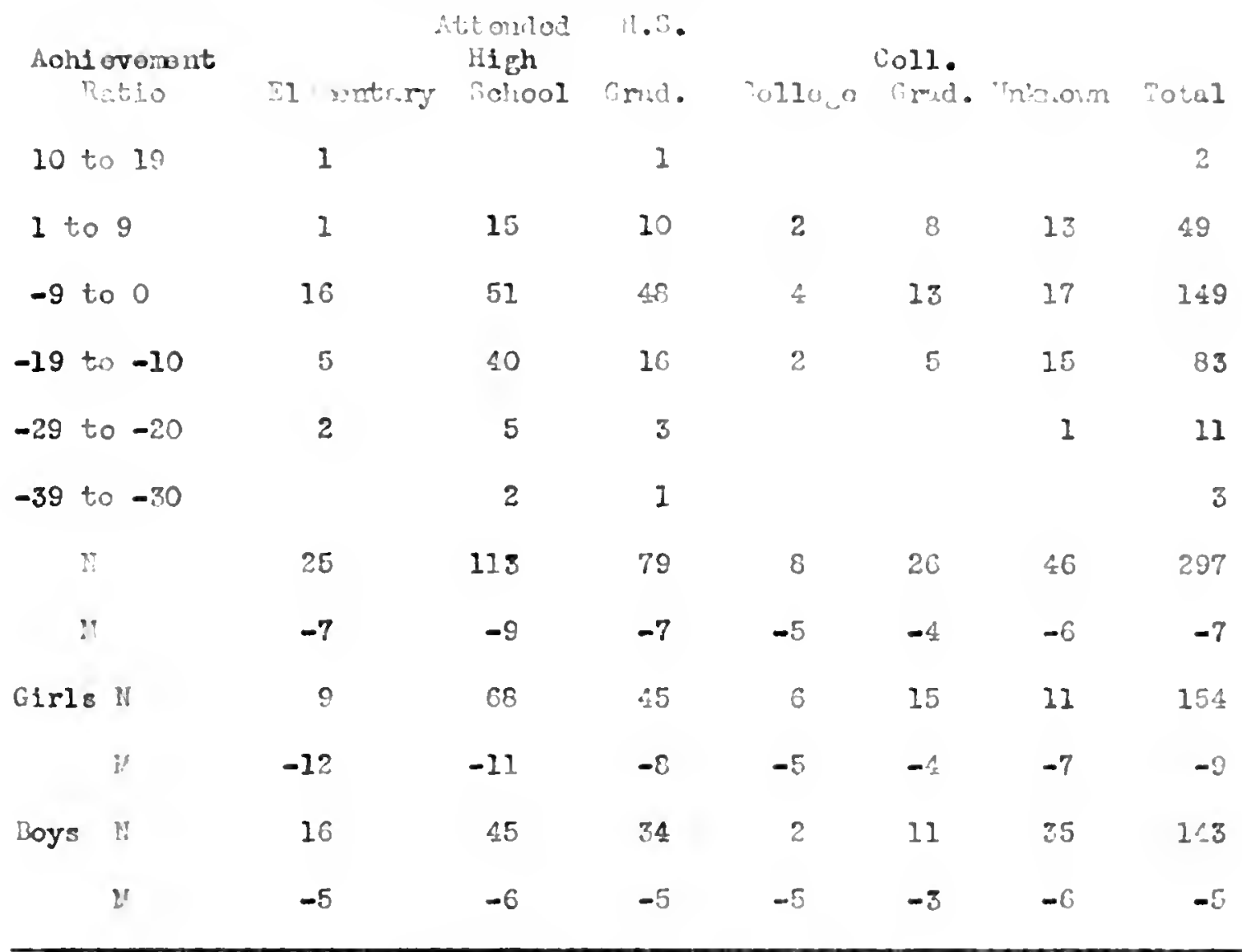

$F($ total group $)=12.248 ; p=.01-$ 

tho boys. "iho sumo reasous thest ucsount ior tho rolationaisip botwo on

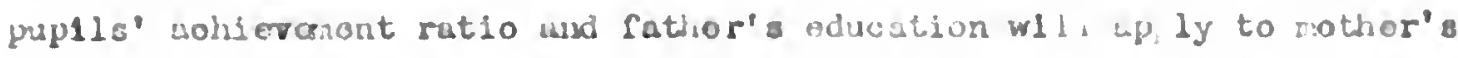

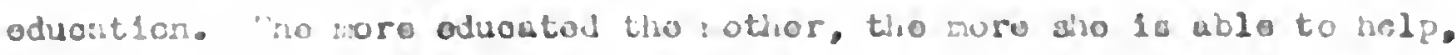
oncourare, and lispiro her childron, urtloularly firle, to lnoremo thel achicranont ratiog in school.

ros a study of tinis rolationsisp and Lio oomprison of pupils' achiovoront ratios with fatior' a adwation, it woild soen that thoro is only a srall jelationchlp botwoen the achlovomont rutio of boyo and the defreo of tho parents ad-cation, willo choro is a rariced

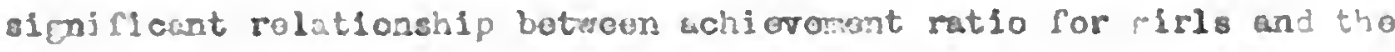
dogreo of paronts' acucation. Fcriaps this is dio to tho fact that the arents axert grastor infliduce ovor firl ohiliron then wy chl1d ren.

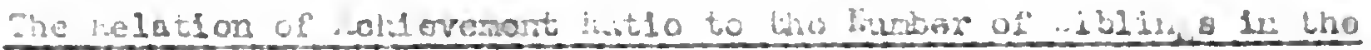
tarl1y.

Thore is some question af to whethor thore is ary relutionahip betwoen the achicvesont rutto of an only child urce a puptl who is a nombor

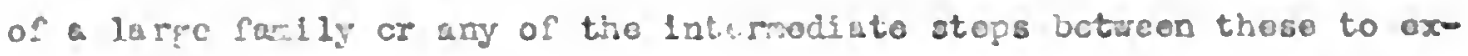
traces. Tho number of sibllice a pupll hs $\mathrm{ms}$ subdividad into coven

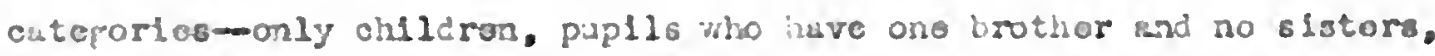
pup1ls who have one olster asd no srothars. ilup1ls wio havo ono brothor wa ono sister, puplis who heve tro brothore and no sictors, pupilo who huvo two siotorg and no brothors, wad pupils who have coro than two brothors and ststors. Who frogumnoy sebla 50 shome that the distribut on is rathor akowod toward tho ri he tooesso of tho largo mumbor of puplis who aro only ohildron or have only ono brother or ástor. "hit 1s truo for both koys and c1rlo ws wull wo tho total croup. Tio f toat lor tho distribution ylelds a valuo of 9.900 whith 10 

- 

sigrirlownt ut tho ono per oant loval. Fhosen la iase than ono ohanro In a hundrod that this wiationahip irotwom ahlovenont $r$ tio and the masbor of stulin; in the fomily to not a blentriant rolstionshlp. filuro 25 ghoss ratior clmarly that tho purilg was aro only onlidros havo a inlfhor soan uohlovomont ritio than thoso guplis who havo tro or moro slblims. tut aro oxcoodod in moen wchlovonont r.tlo by tho prpila viro have ono silling. Tho oro oxcoption is the relntionship lol tho total rroup is that the puplls who hiso ono urothor and onc sigtor huvo a moun uchioronent rutio wilich oljals tho moun aciriovo:ant ratio for the only ohlldren. For the total froup tho cutapory havin tho .iffrost woun achlowoent retio 18 tho puplis pho have ons ol btor ard no rothors.

hers tho pirls only aro corparod. It ap.ours that amin tho araller the namber of aiblinrs, tho hirhor who noun ahioversent ratio. Nils is not gurte so noticoablo in tho croo of anly cirl chlliren. To moan ahievorant retio of tho ontororios of pirls by rank is as follans (1) firle isaviar ano uruthor, no slatores (2) ilria iavine ono sigtor. no lrothars; (3) Arla lavine cne brother ard ono sister; (4) only irl ohildrcn tiod with girlo having two ators, no vrotiors (5) (1ris havinf noro than two brothers or siotere; (6) Eirls huving tho larost

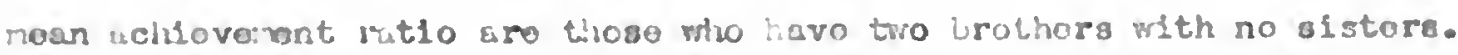

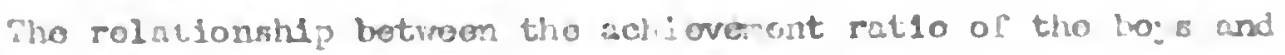

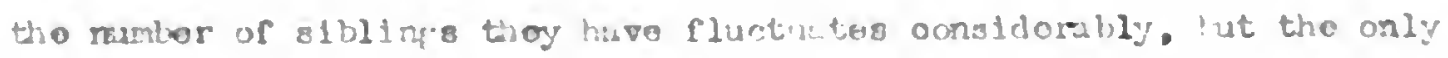

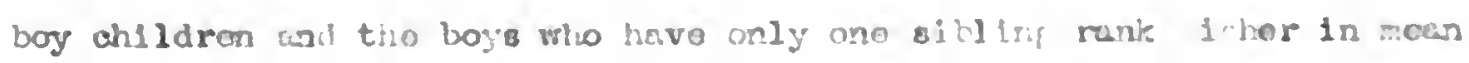

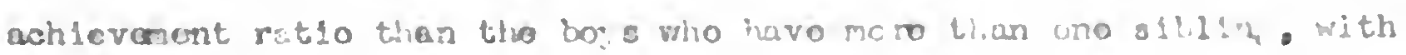

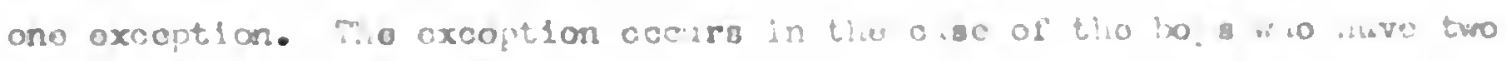

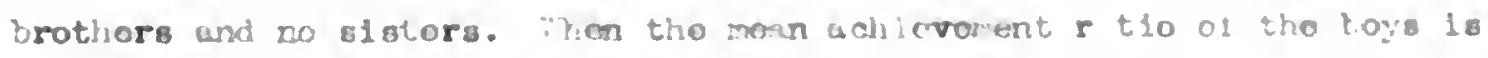

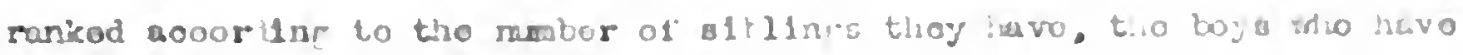



ano alstor und no rothers or two brothere und no alstors. ro tlod for tho hichost mata uallevenont ratlo, tho hoye who aro only chiliron ani the ino who lave one brotlior and no slator aro tiod in tho nupt position. followod by tio boys who hisvo ono brother and ond siats. then tho boys

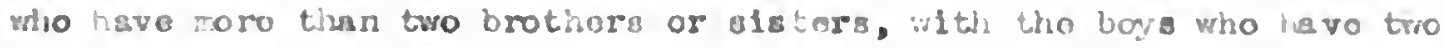
olstors and no brothoro ranilng, lowost in roan uchiovomont ratio.

In conorel, It coems timet for bo s. pirls ant the total froun. tho anallar tho number of sibling:a tho ifhor the achiovanont ratio la likoly to bo. rifitts 109 and urahl ${ }^{170}$ cane to tho sano conolualon.

Tho relutionshlp which oxlsta betwoen adicvaront ratio und tho number of sliling in the fasily on to accounted for in a nutbor of

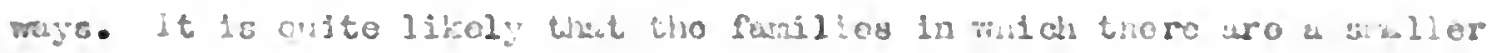

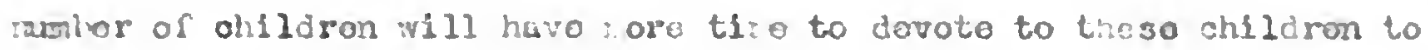
help and onooururo thom to put forth tilop bosi offorts in ahcool. It

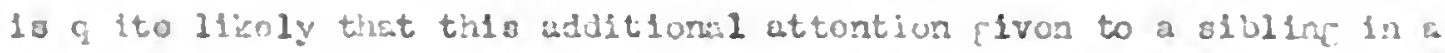

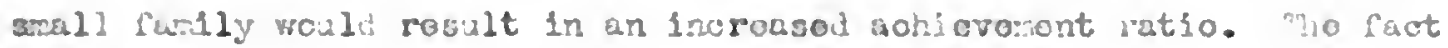
that the only cillidran do not hevo the il thoot roan wel lovement rutios Loy bo aocounto: for liy eaylne that ferliaps theso only ahildron aro

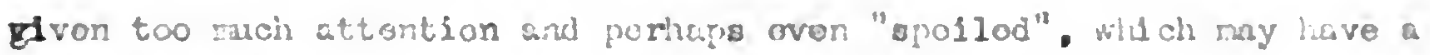

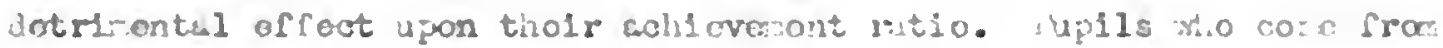

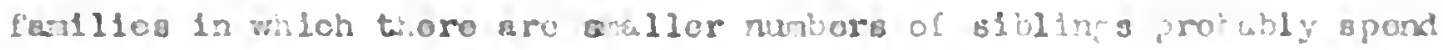

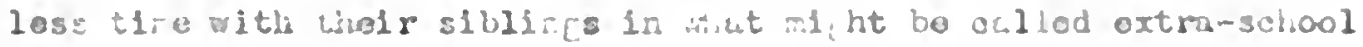

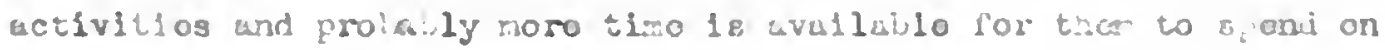

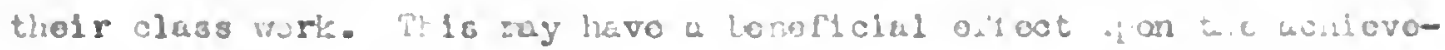
mont retio of Fiulls livirr in arisl farilion

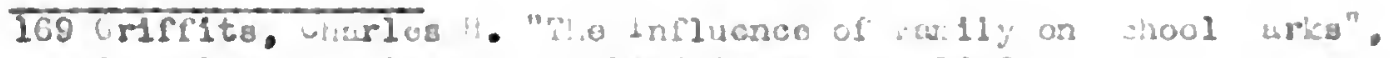

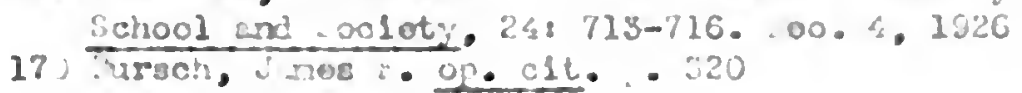





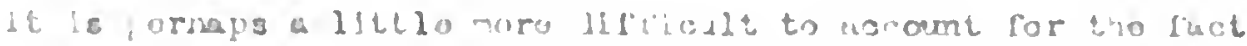
that tiat proup of Eirls who havo tho lorost woin unhlmomemt ratio is thin proup wio biro two brothors and no sisters, willo that rot of

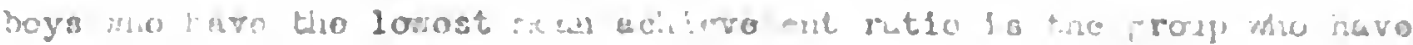

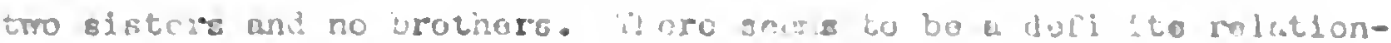

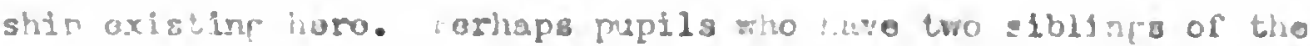
oprobito snx and noze of tholr om sox, wro dikul: to. Avo lowbr Iutan

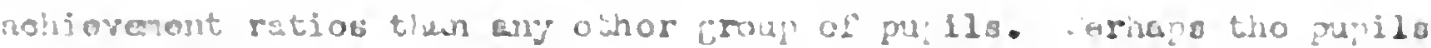

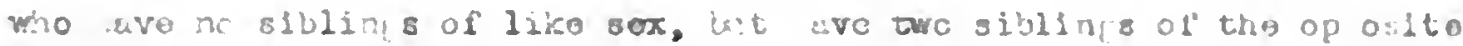

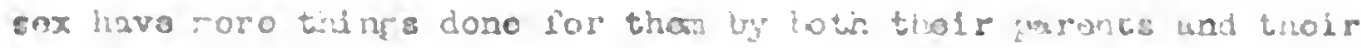

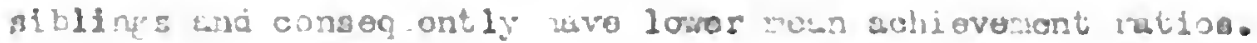

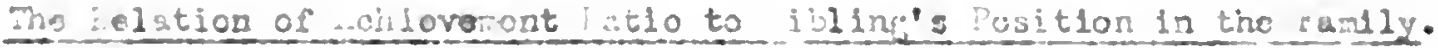

This rerieblo is dificd into throc outororlez-tho yoursogt Allitife 1. ferlides form one cuterory, puplls tho aro oldast and

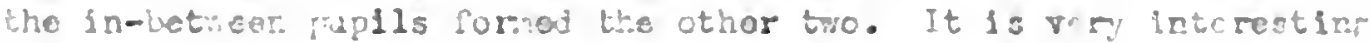
to nolo trat thero are loss rila in tio in-betwour catarory tiun in clthel of the cther two. Iho rreruenov alstritition is of the flat

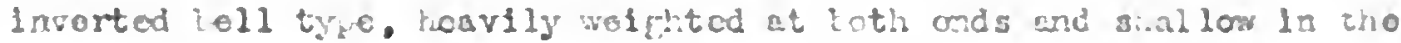
nidd10. "hero aro 95 youngut chllden, 5i ruithnr younfoat nor oldost. and 83 oldest ohildron inclided is tho study. Tho raxiniar chlidron aro calj chlidron.

Who: wast for tho to:ul croup viclds = val.. of 7.052 whlok 18

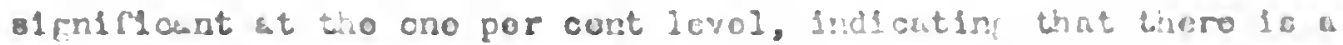

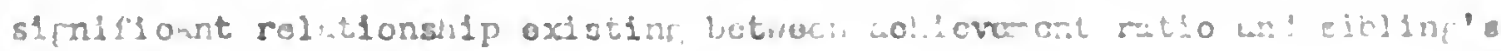
porition in ine rusily.

Heforonco to iablo 10 lmloatos t et the oldust childron huro tho 



\section{TABL: 39}

Mistribution of hohiavonent it lies hocordiag

to the Numbor of Siblinge in lunily civine, the ineans for icys and firis coprratoly.

Achiovamant Only 1 L 1 S. 1 B. 2 . 25.26

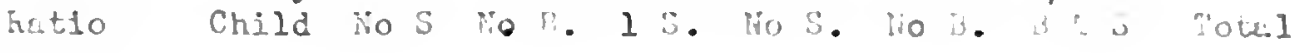

10 to $19 \quad 1 \quad 1$

2

$\begin{array}{lllllllll}1 & \text { to } 9 & 7 & 12 & 10 & 6 & 3 & 5 & 6\end{array}$

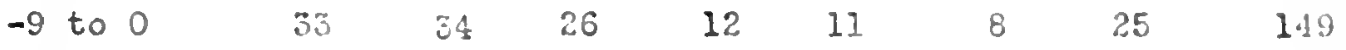

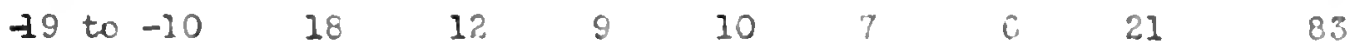

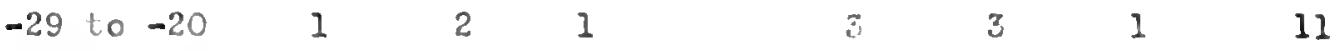

$\begin{array}{llllll}-39 & \text { to } & -30 & 1 & 1 & 1\end{array}$

\begin{tabular}{|c|c|c|c|c|c|c|c|c|c|}
\hline iv & & 61 & 62 & 406 & 28 & 21 & 22 & 54 & 297 \\
\hline L & & -7 & $-t$ & -5 & -6 & -9 & -3 & -9 & -7 \\
\hline Girls & $\mathrm{N}$ & 35 & 27 & 20 & 16 & 14 & 11 & 31 & 154 \\
\hline & Y & -9 & -6 & -7 & -7 & -13 & -9 & -10 & -9 \\
\hline Boys & $x$ & 20 & 35 & 26 & 12 & 10 & 12 & 23 & $1+3$ \\
\hline & $h^{\prime}$ & -5 & -5 & -4 & -6 & -4 & -8 & -7 & -5 \\
\hline
\end{tabular}







\section{TABLE 40}

Diatribution of Achiovemont Ratios Ansorisno to the Sibling's Position in Family ing. +tu

Manns for Boye and Girla Separatoly.

SIBLING'S POSITION IN FAMILY

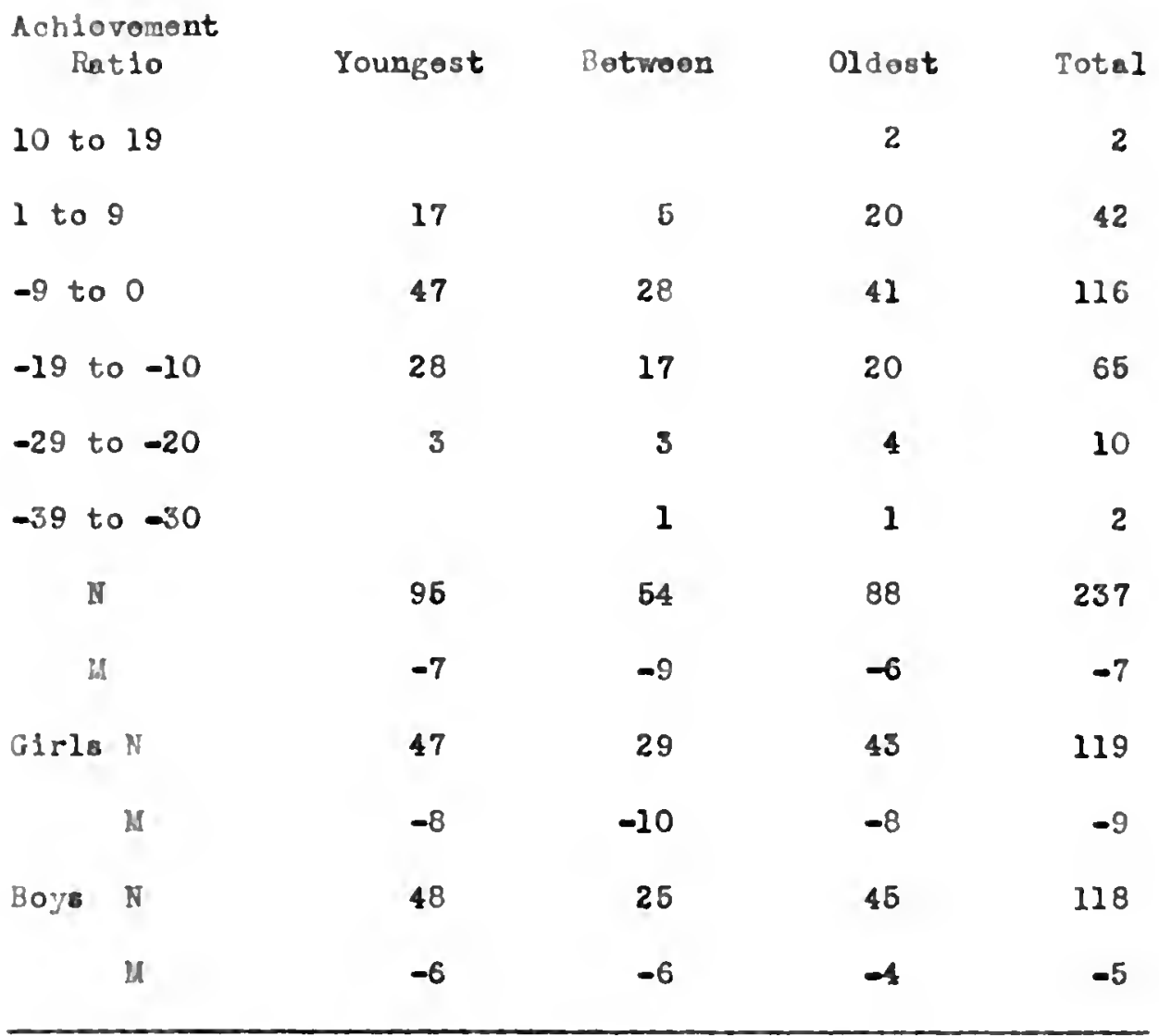

$F($ total group $)=7.052 ; p=.01-$ 


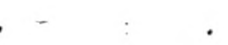


highost nown aohlovament rotlo with tho youngost ohl ldren rankin, aecond. the anly childran rankling thl rd, and the ohildren who wore not thor youngest nor oldest ranking lowost in moan nohlovecent ratio.

Tino same oltugition hold true for the girla, oxoept that the oldest children and the youngest ohildron all tlod in moan achievement rat10 two polnts aboro the mean aohlevement ratio for the inbotwoen pirl $2151125^{3}$

Thore is a slight variation whon tho relntionship botwoen the bog's position 1r. the factly und thelr nondevement ratio 18 obs rvod. It Is noted that the joumpost snl nolther youmest ror oldest oblidren reve the sesu acen achlovment ratlo and that both proups are oxoolled by the oldost Eroup.

The rointionshin between the echiovemert ratio and the sibline's position in the fumily may be accounted for in sereral ways. The oldest elbllnes probably have to approeoh tholr problem with the lenut ans stanve fros tholr :ounger hrothorn and slaters ind oansoquentiy develop hablte of action which hive a benofiolal influozoo upan thulr oubleveront ret10. The youngest chlldren ranked below tho olicst cilldran and above tho ramining, chlldren. Forhape tinlo is boauso thoy racelvo so much attentlor, encourapocet, ens holo from tholr paronts and thelr

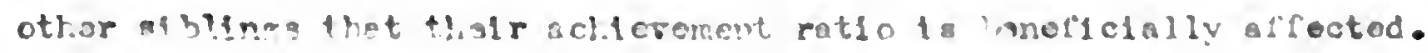
The lobetwean ctildron are grentably the zoet nerlocted rroup, probably having the novelty of the takks taken off thelr older sblinpa, but

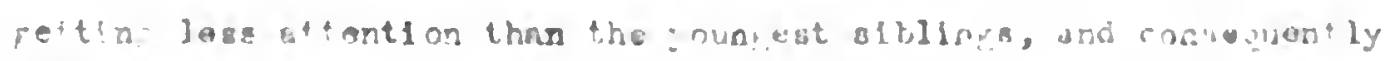

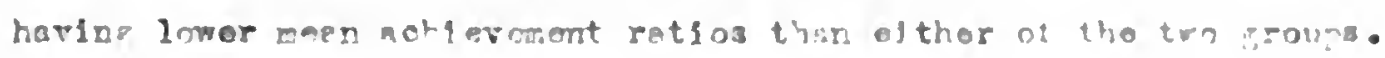

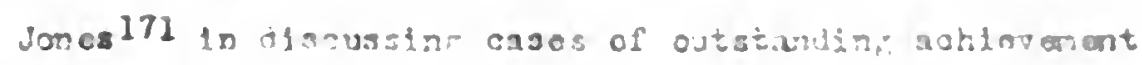





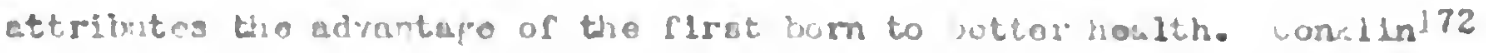
on tho other liund. Plnde nolthor the aucoosstul nor fullinf: puglis of su crior Intollifenoc ohow ing prodominence ol ravoruble poeition wanp thoir clilinge.

Tho olstion of aldevemsnt lutio to nvironront - irsl or iriven Tho rossuro of onviromont soloctul wres dotorinod by which of 4

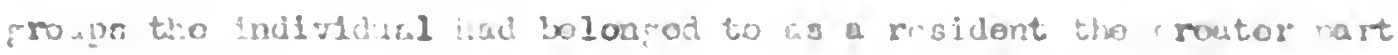

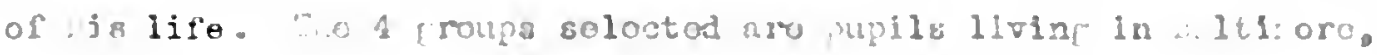

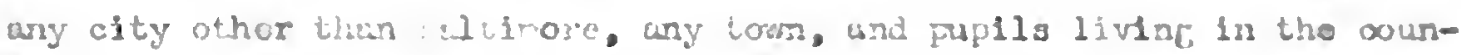
try. The very f rast ra jority of tho cusos (205) havo spont tio f rostur past of thoir livod in tho eity of isti orc. Tio rominiaf z2 casos

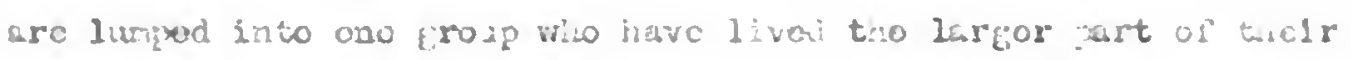

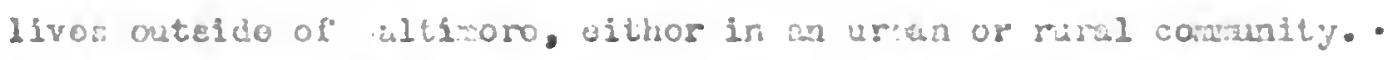

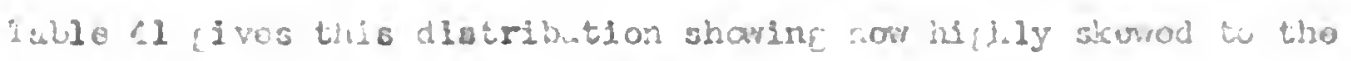
ritht it ic for tho beys. irle und totul proup.

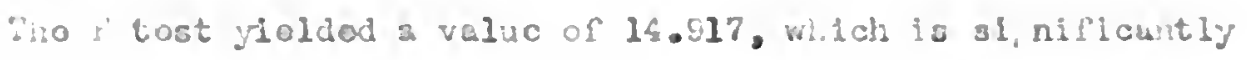
hill omoupl: to rulo out tho null hathosis that no rolationsilp odsts

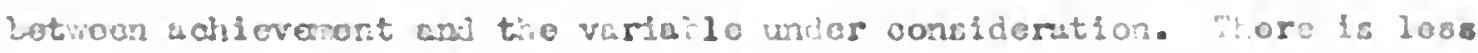

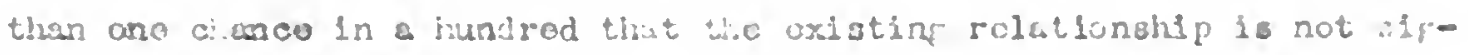
al isont.

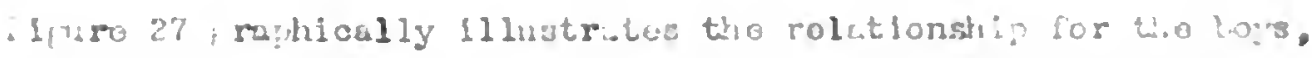

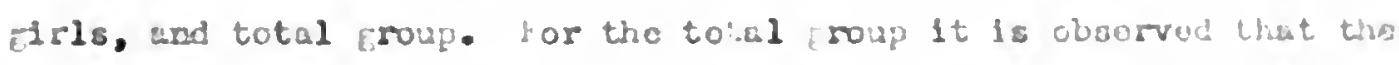
woun achiovonont rutio for tho nativo altimoroano id alcnlisunty

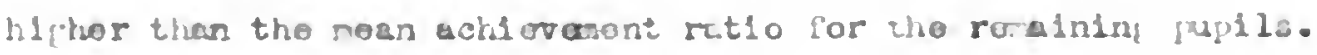




$$
\bullet
$$


Cnly \& ent.11 numbor (14) of the pupilo stusiod hivo opent tho proator

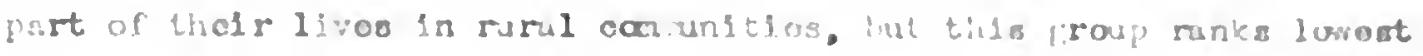
in cohievanent ret10. inis le not indicutod on tho duta ivon, lut 1s roroly addod horo so a rattor of inforticlion.

on the firls alono aro conaliorod, it is obsorved fron. firo 27 that the moun wohiovanent rutio for tho netivo. It

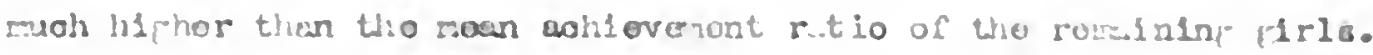

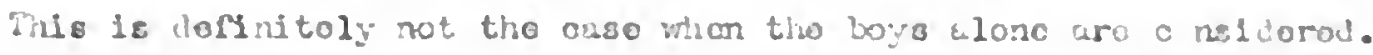
in fuct, thoro 18 no difforcuco at ell 1:l rom cohievement ratso for

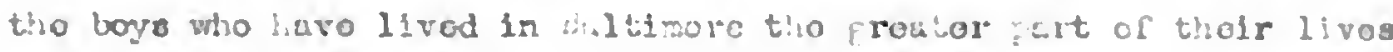
anc tho bo:s who lisvo livod out of icitinoro. ividently, tho sifsiflest rolationshp oxistlne botwcon this wspoct of anviron ert and achlevenont ratio is due entirely to the influonoo of tio. irls. inero tho irle in this study are concornod, thith achievonent ratio is assoclat d uth livine. In valisom, und lov woldovenont p tio is wisocistod

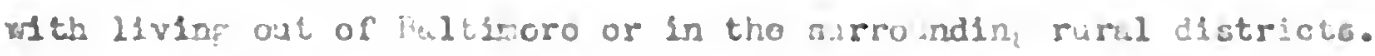

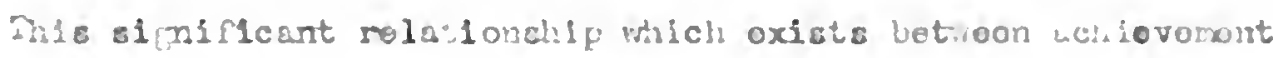
ratio and tilis aspot of environicat for irls and nol for boy s ray be scovinted for in this way. abo incrased udvintaros of a motro-

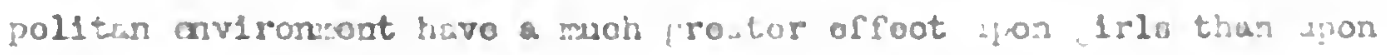

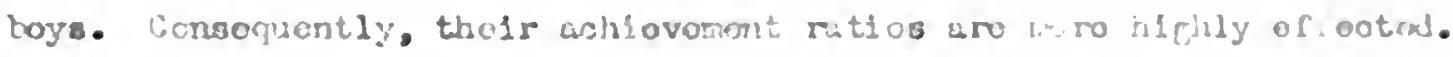

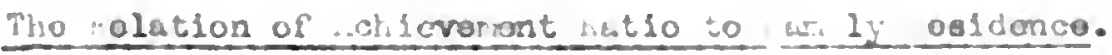

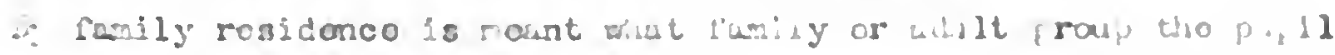

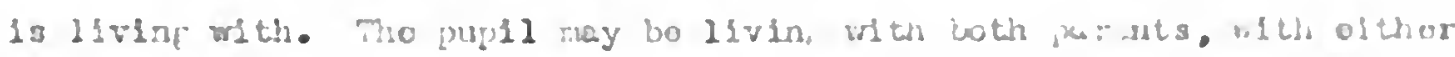

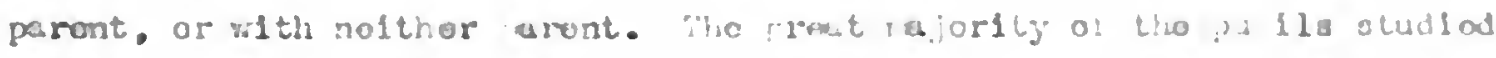

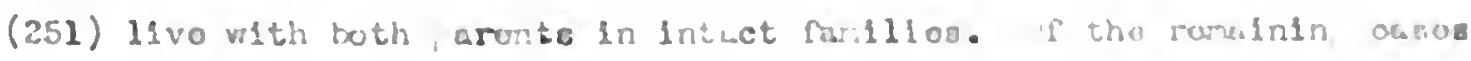


TABLE 41

Distribution of Aohlovoment Ratlos Aooordin: to Environmont Giving tho "oang for lloye and Girlo Soparately.

ENVIRONMERT

Achlovemont Rat10

10 to 19

1 to 9

-9 to 0

-19 to -10

-29 to -20

-39 to -30

N

u

Girls N

$\mu$

Boye I

M
Baltimoro

2

48

130

77

9

266

$-7$

133

$-8$

133

$-5$ out of

Baltimoro

Total

2

49

19

149

83

11

3

31

297

$-11$

$-7$

21

154

$-14$

$-9$

10

143

$F($ total group $)=14.917 ;:=.01-$ 


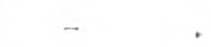





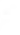




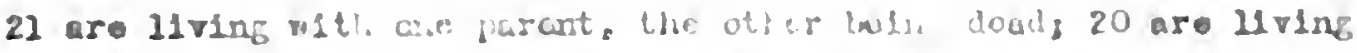
with one purent, tho other boing seloratods and 5 aro ofrod fur by guard lans.

The Srequaroj dietribution in Table 42 paitrolly tives a distributlan wheh is highly okowed to the Fitht for the boys. Blrla. wad tho totkl froup. "Iflro 28 111ustratos graphloally tho rolationehlp botreen achleverent rat10 and foully residonoe for the total group. RIrlo and boys. For the tolul group hich achloranent ratio is cppereatly assoclatod with tho pupll whose preats are sogarsted. Sho pliblo who have the next hlchoet achleveruat retlo wre those who are 11 lifi, with both parcuts. follawed by the puplls who hate ane parent doad. with. the pup128 11Vlng Fith nolther parent reaking lowest in aean aohloyocent ratio. When the wean achlevenent rat1o of ablidren frcm brokon farallos is compared with the mean achlevant ratlo of ohildren fror Intact failleo, It is obsorved thet the ahildren from broken farliles had a s il tht advantage.

The $F$ test. Fiolding a value of 4.998 . Ind cates that the rolotlon-

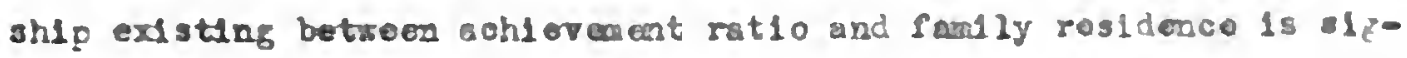
nlflcant at the ano per cent 10rol. Iligh achievenust ratio is assoolatod with troken famlios to \& 81 rafleant dogroo.

The rolet1oashig 18 quito markod in the caso of the boye whoro the boya fram brokon familles hero oonsldorably hi gher aban aolueveant rat10 than elther the boge who have one parent deal or boys who are IIVig with both parento. Whoro the Girls only aro consldered, tho relationahlp is not co well markod. Ihe flrl who aro $11 \mathrm{vine}$ with both paruats have hiphor moan achlevessent ratlo then any of tho othor 3 groupa of firle. but the 61rle whose parents waro soperatod have a hor 



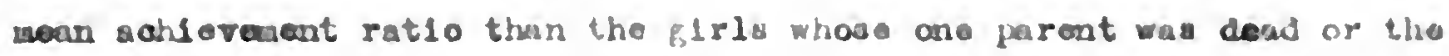
Blrls who aro not $11 v$ fre with of ther parent. It would soon that luch

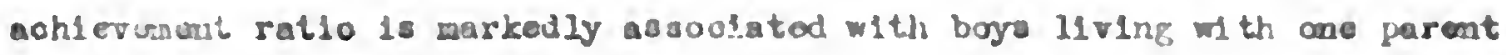
when their paronts aro soparatod nul with firle 11 vinc with both paronta.

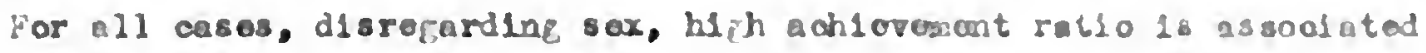
with punlig living with one parent with tho other soparatod. Aoocunting for this relatianehlp which oxdsts between the high aoblevecent ratio uni ianliy roslionce is quito a difloult mattor. It soens apparant that the boys who are 11 ing with one of two soparated parents aro stiraulated 12 some way to work hardor in sohool than any of the othor threo groupn of boys atudied. Parhape this is due to tho fact that in not soparated fanliles the pup118 11 ve wh thelr pothere. and the wothorg havo to work in order to malntain the hase while the chlldren go to sohool. In the esso of s boy who 10 attendlag 8 chool, this is probably a powernl inoontive to loars as woh as tho can as quilakly as ho can so that he ray rollowe his mother of tho hardehl ps connooted wh supporting tho farily.

In tho caso of the girlo who ere IIVIng, with ono of two separnted parents. In mast cases tho mother, high aohlevesent ratio is not so ordent. The girls ovidontly aro not quito so hlghly otleulatod by such a situation, although they do oreel la sean achiovocent ratio those G1rle who are livlof, aith one purest with the othor dead, or with nolthor parent. In the case of tho girle, it sooss that $11 \mathrm{finf}$ with both paronte togother 1a en adventago which holpe to koop up thels gean aohievesent rat10.

As Par as the eatlre Erou, 18 oanoernod, tho Influanoe of the boys 1. oufflclent to ake the meau achlovarent ratio for all of tho puplle 


\section{TABLE, 12}

Distribution of Aohiovomont Ratios Aooordin to

Fasily Rosidenco Giving the Ifonns for Boys and Girla Seprrately.

\section{FAUILY RESIDENCB}

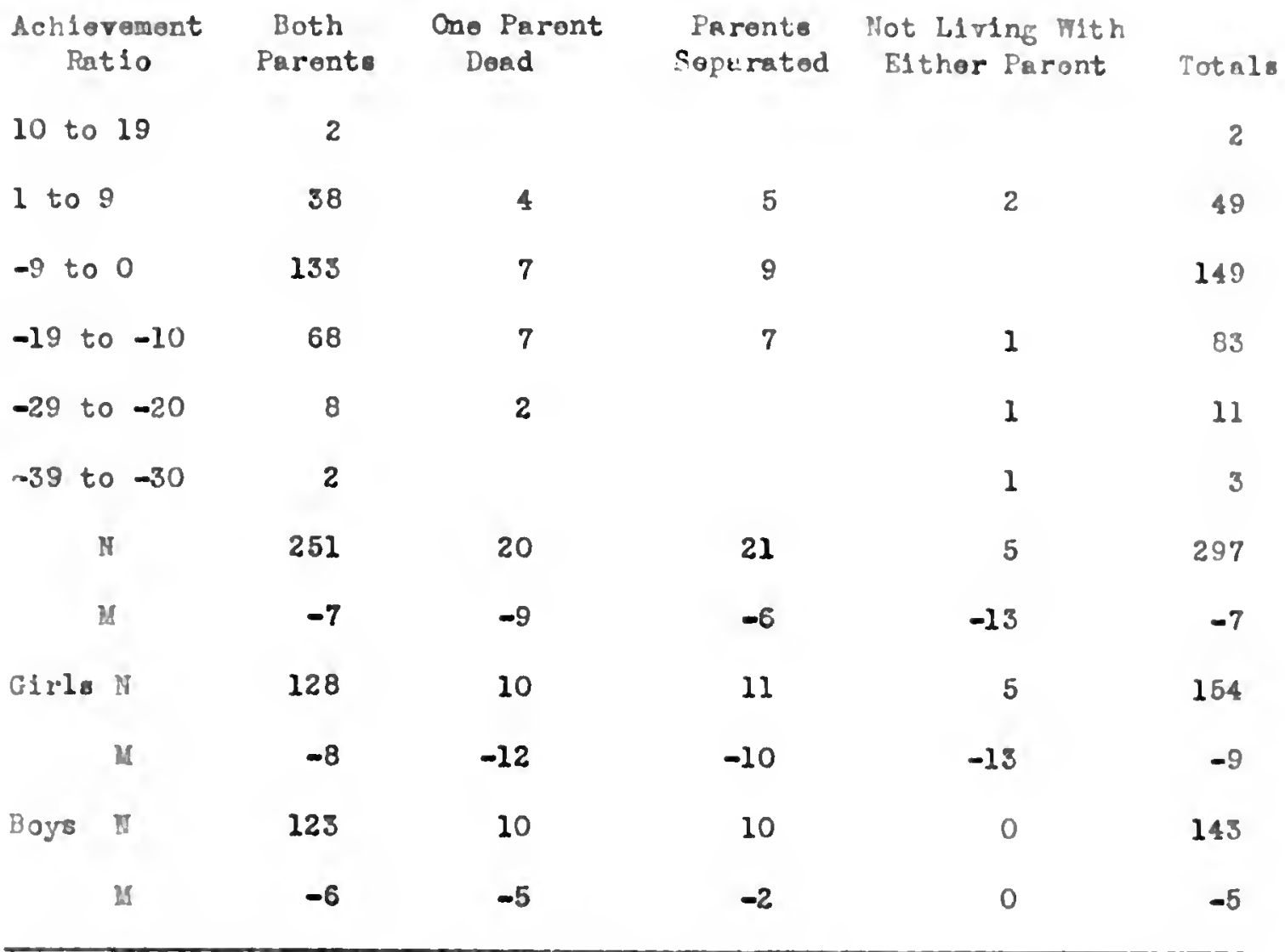

$F($ total group $)=4.998 ; p=.01-$ 

In the sopernted fumlly group axool the monn eohlovoment rntio of tho othor 3 groups, but ovon with the total group the influonoo of the firls is strong onough to mak the punils who gro livini with both parents rank seoond in moan achiovement ratio.

Conklinl73 finds no roliable difformnan hatweon suocossful and falline puplis in the soparation of prents, lit jusinglit finds thet ohildren of soparatod arenta gain loss in cohlovomnt than s thuc trom intact homes. The findings of this study for boys on this variablo aro in genoral disagreement with those of most investifators, including Conklin and Desing. The findings for glrls, however, aro in essential agreement.

The Relation of Aohieremont Ratio to Pupil's Health I

The estimates of the nurse and doctor, based upon a complete physion examination given the muril, determino whother the pupil's hoalth is

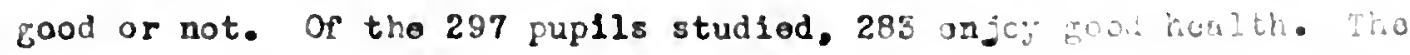
14 reminin, cases are considered by both the doctor and nurse to have poor health.

Table 43 Indioetes how highly sewed the distribution is to the right. as a result of the groat mejority of tho pupils heving good hoolth. Tlis Is truo for both boys and firls as well as for the total group.

The $F$ test yielded a value of 1.32 whioh was not signifioant. Thero are more than firo ohanoes in a hundrod that no rolationship existo botwoen this moasure of pupil's hoalth and achiorement ratio.

It is interosting to note that the girls with good houlth had highor mean aohieroment retlo than the firle with poor hoalth, whilo the boys 




$$
\text { . }
$$


T.3LE 4.

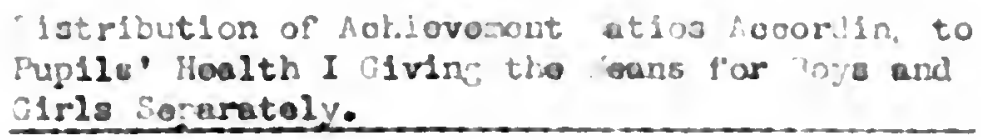

\section{PTILILS IIEALTI?}

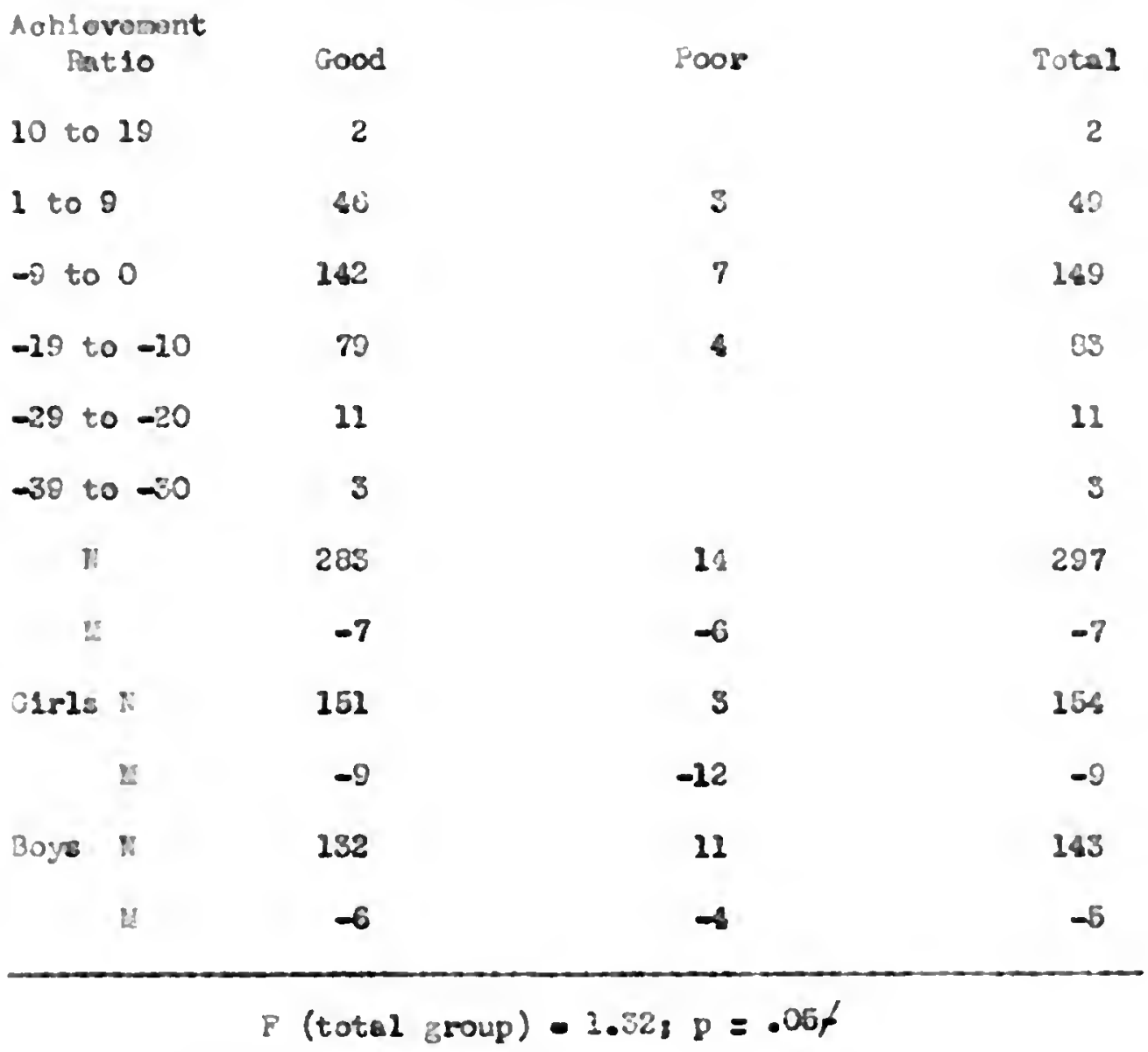

with poor hoalth have a highor moan aohievoment ratio than tho toys with good health, but agein the number of oasos in tho poor hoalth sute;ory 18 so small that the relationahip is not slmalioant.

Such a findinf 18 not hard to aocount for beonuso of tho $\operatorname{small}$ number of anos in one of the two aterortes inoluded in tho v rintulo and also beccuse tho mean achievement ratlos for the tro prouper uro only one point apart. 



\section{TABLE, 44}

Distribution of Aohloromonts Pnt1os $\Lambda$ ocording to Pupila' Hoalth II Giviné the "cans for Boys and Girls Soparately.

\section{PUPILS' HFALTH II}

\begin{tabular}{|c|c|c|c|c|}
\hline \multicolumn{5}{|c|}{ Achiovoment } \\
\hline \multicolumn{2}{|c|}{ Rat 1o } & 1.2 Divoasos & 3 nis & Total \\
\hline \multicolumn{3}{|c|}{10 to 19} & 2 & 2 \\
\hline \multicolumn{2}{|c|}{1 to 9} & 15 & 36 & 49 \\
\hline \multicolumn{2}{|c|}{-9 to 0} & 30 & 119 & 149 \\
\hline \multicolumn{2}{|c|}{-19 to -10} & 19 & 64 & 83 \\
\hline \multicolumn{2}{|c|}{-2.9 to -20} & 2 & 9 & 12 \\
\hline \multicolumn{2}{|c|}{-39 to -30} & & 3 & 3 \\
\hline \multicolumn{2}{|c|}{$N$} & 64 & 233 & 297 \\
\hline \multicolumn{2}{|c|}{$\because a$} & -7 & -7 & -7 \\
\hline \multirow[t]{2}{*}{ Glrls } & $\mathrm{x}^{\mathrm{r}}$ & 26 & 128 & 154 \\
\hline & H & -8 & -9 & -9 \\
\hline \multirow[t]{2}{*}{ Boys } & ri & 38 & 105 & 143 \\
\hline & 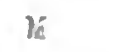 & -5 & -5 & -5 \\
\hline
\end{tabular}




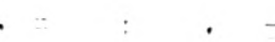




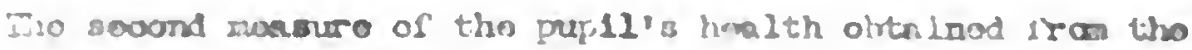

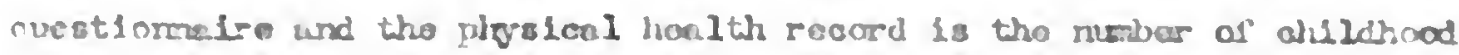
disonses ach puill has contrnctactod. If the 297 pupllo stu 10d. 233 of

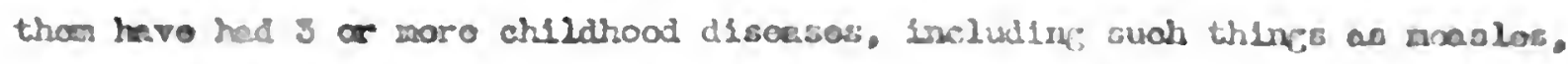

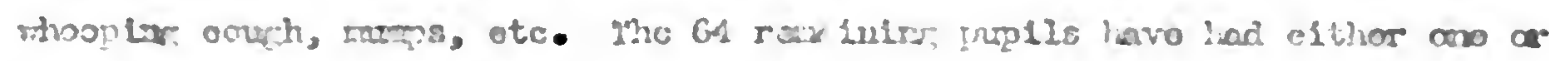
two suoh cilldhat alscosos.

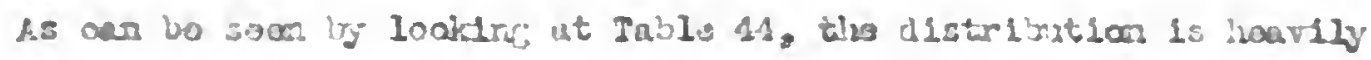

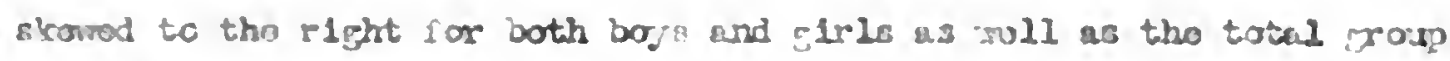
bocanso of this reot.

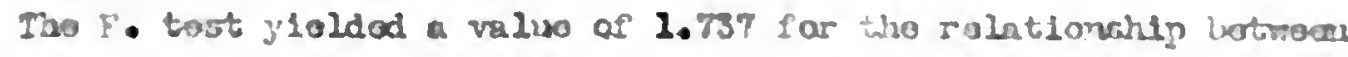

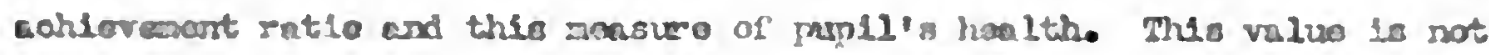

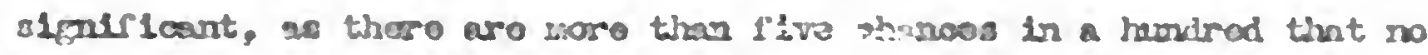

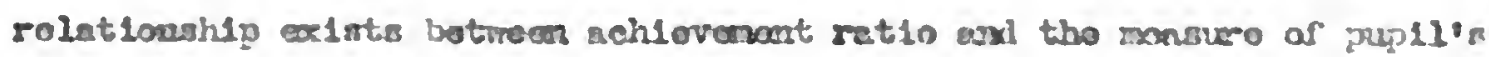
hoalth.

Flguro 30 11lustrates how olosely tha moan aclierwont rstlo for tho two proupe is rolatad. For tho total proup, tho moen echlowarant

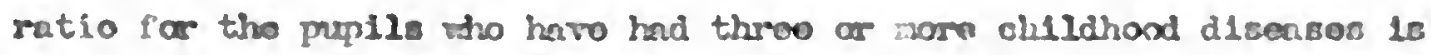
conotly tho aeso as tho moar achlorenont ratio for tho puills who havo had on or two childhood d10easos. Tho arro thing is truo far the bogs,

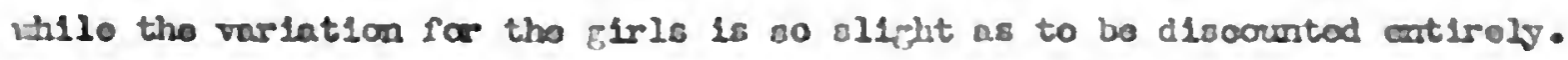
Evidontly tho manbar of chlldhood disonoos contractod if a prall has nothlac to do with hio maces schlovesnant ratio.

This 1 probably duo to tho fect that most ahlldroor diswares

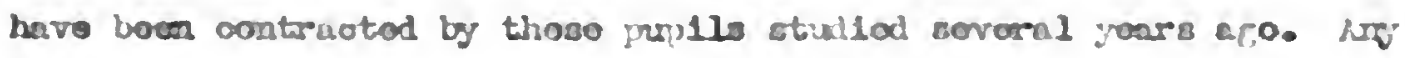
offoct cuusad by tho chlldhood disonoos rould probably malco itcolf lolt 



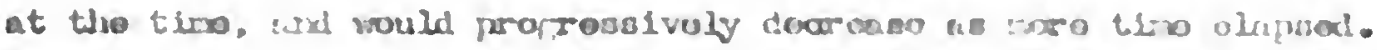

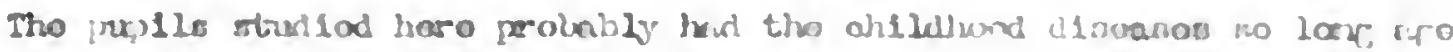

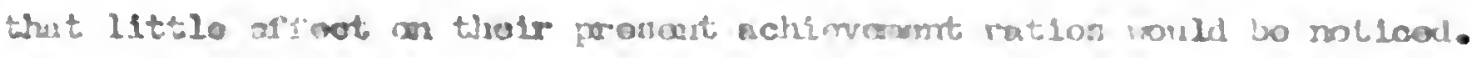
Thase findinge oomocontine, the role:tion af puplls hacth ax

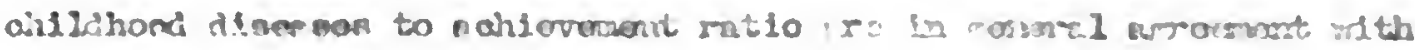
Whow af coniclist. 175

175 Conklin, Arnos, gp. c1l. D. 216. 



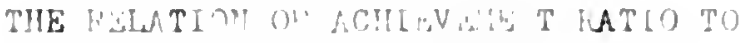

IALIF is' SIIH

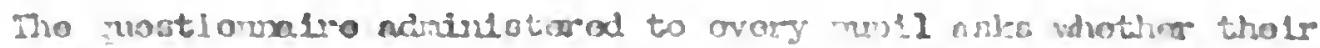

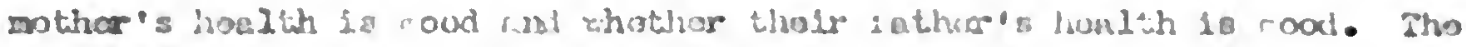

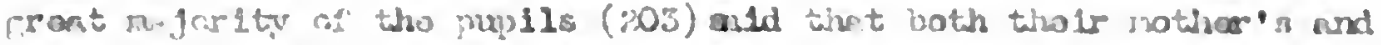

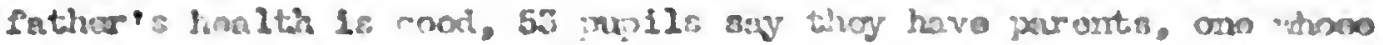
houlth 18 roxi nad on those heulth 18 poor, 26 punlla havo orly ano

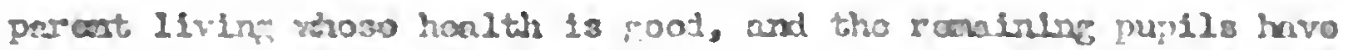
peraxts both of thoso hoalth si poor. Tabin 45 shoms that tho diso

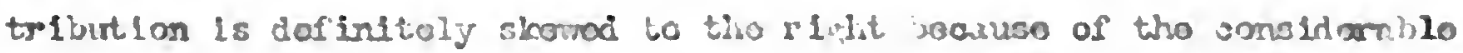
zarbor of puptle both thaso paronte' health is fepod. This is trin far boys and -2rle ae moll cs far tho totr. rroup.

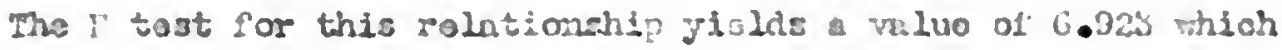
is sipnificum at tho on per cont loval. Thta li indeatos tint proiln

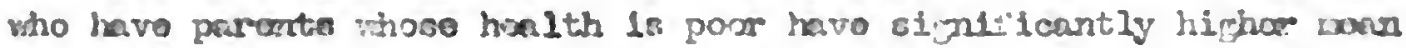

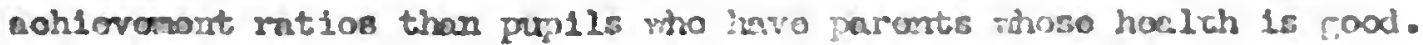

Raforonoo to Fleme 31 beling out this polnt. Tho pupils itwo

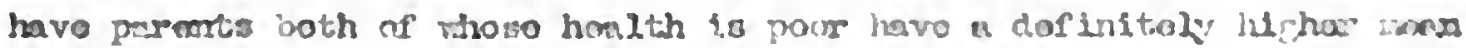

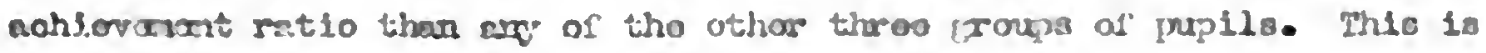
true foe both the bogr, eirle, and tho total morre.

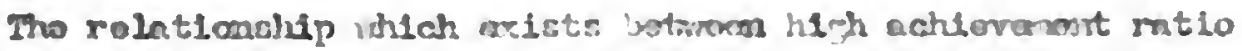

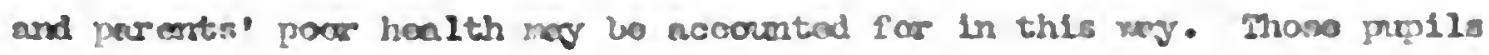

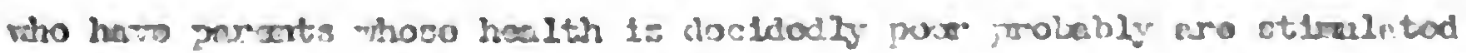
by mooselty to mole no hand we thoy ors in and out nf sohmol no thit

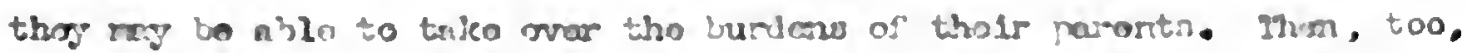



these puplls whose parants havo poor houlth may be filva a grentor appreatation of the advantafos of an oduation than puplis who do not have this handloap. In wll probablilty, how ovur, this 18 meroly anothor Instanoe or Indioktion that possesolon of a handicap tends to make the possessor of that handioup work hardor to ovorcone it than ho ordinarly would; and, in so working to overcono tho handicap, hl s moan achlovement ratio is increased. 



\section{TAILE 45.}

DISTRIBUTION OF ACHIEVE2:LII RATIOS ACCOFUIPG TO PARETTS HENLTH GIVING THE MEANS IOR BOYS NID GIRIS SEPARATELY.

shi evernent

\section{Rat10}

to 19

to 9

to 0

19 to -10

29 to -20

39 to -30

H

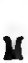

Irls $\mathrm{N}$

y

oys N

y
PARENTS ' I!EALTII

Both Parents Ono Good Both

Health rood
One Pursont

yead
Total

2

49

149

83

11

3

53

15

26

297

$-7$

$-7$

$-3$

$-9$

$-7$

212

20

16

154

$-8$

$-9$

$-7$

$-11$

$-9$

91

33

10

143

$-6$

$-1$

$-5$

$-5$ 


\section{•}




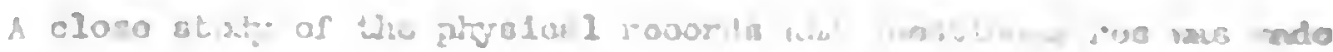

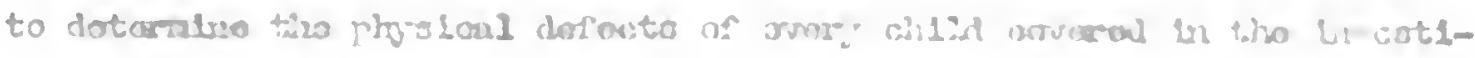

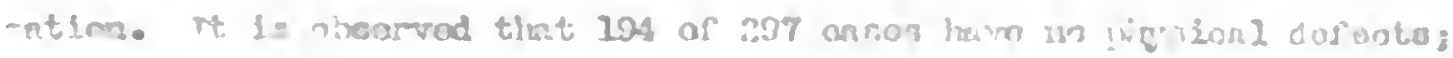

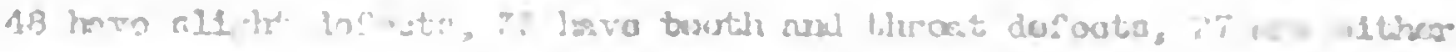

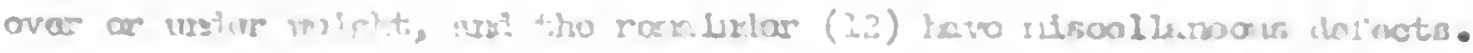

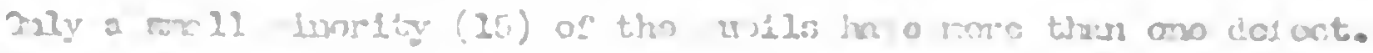

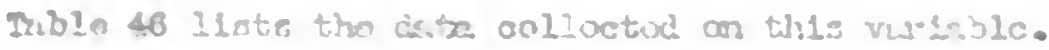

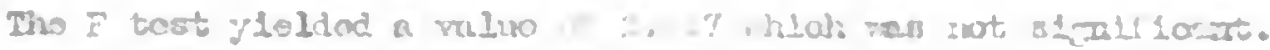

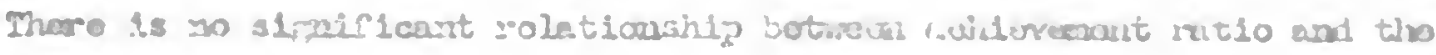

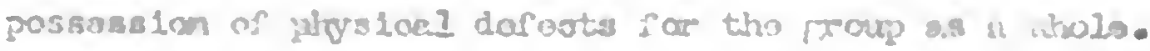

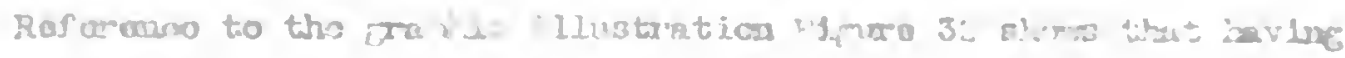

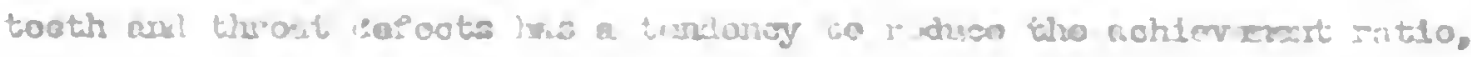

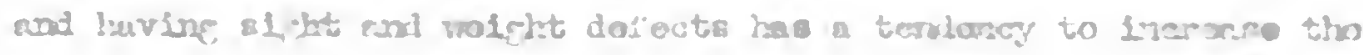
ach.erwarsert ratio.

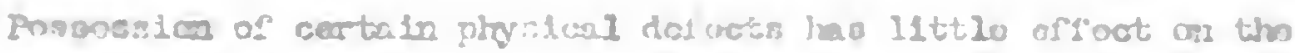

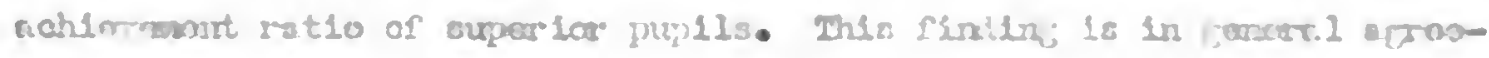
mat with tisnt of akort and il1218. 173

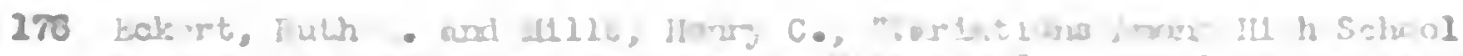

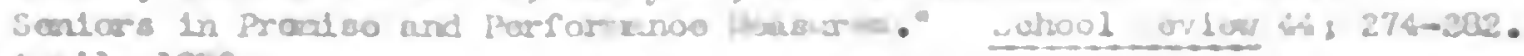
Rpir11, $10: 6$. 



\section{TABLE 46}

DISTRIBUIION OF ACHILVEZERT RAIIOS ACCORDING TO

PUYILS' PHYSICAI DEFEXT'S, GIVING TTH MEANS FAR HOYS AND GIKLS SEPALA:ELY.

Aohlovent

Ratio

PUPILS' IHYSICAI DIEETS

lione

Tooth \&

Sient

Throat only

Welght

Only

Throat only

only

Hiso.

Total

10 to 19

2

1

2

32

6

3

6

49

93

21

10

12

13

149

-19 to -10

57

8

5

5

83

-29 to $-20 \quad 10$

0

1

11

-39 to $-30 \quad 2$

0

1

3

N

194

36

23

20

24

207

K

$-8$

$-5$

$-8$

$-6$

$-5$

$-7$

Girls N 207

14

16

11

6

154

u

$-9$

$-10$

$-5$

$-9$

$-9$

Boys N

87

22

7

9

28

143

L

$-6$

$-3$

$-5$

$-7$

$-2$

$-5$

$F\left(\right.$ total $\left._{\text {Group }}\right)=2.217 . p=.05+$ 

THE RELATIOA O AUHSVILET KATO TO

HOW: DISC IPLITE

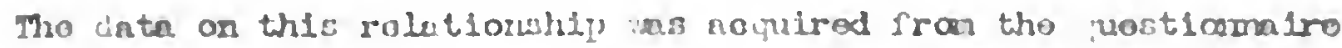
In whlch tho priplite aro nsked whioh nothode are usad at homo to disolplino. It ves disooreral that the manity (121) of puill't paranto use tho sothod of dopriving tho pupils of privilegeg. 67 parants locture tho pup118. 23 parente uso a combination of tho f'lret tro. 10 pereats uso uhipninf as a rathod of disolplino, 36 uve nothins as a nothod of discipline, and tho raminler use nisoollanoous farms of discipline. Tho 1requenoy distrlbutian, As show in Teblo 47 sa honvily skevad to tho ripht for boge, firls, and tio total proup.

Tho $P$ tost jlelded a valuo of 3.546 miloh vac slenirlonnt at tho 16 10vol. Tharo is loss than ane chanco in a hundrod that no rolatian ship axlited batroun hura disofpliswo and achlervowant ratio.

The Eraphio illustration Finure 33 Indicates that tho pup11s tho aro doprived of privileges by hoir paranta as a nothud of puniaknant havo e lower nown achiovenont rutio than the gupils who aro locturod or

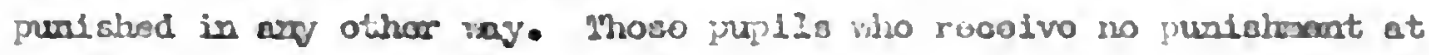
all rank just abovo thea in mown achlovanoist ratio.

Svarpelalnely mourh, tho nothod of disciplino usod by parants;

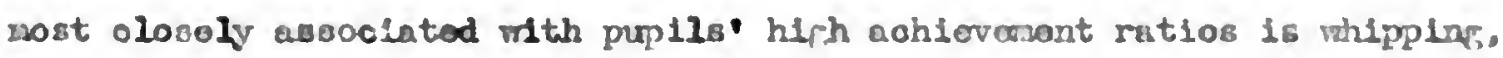
olosoly followad by locturing. Apparontly low achlovecuant ratio Is asaciatod with dopriving of privilopos or no homo disolplim at all. and hich achlevemont ratio is asooolatod wth whipping and looturing. It rould oocs that the noro disagroonblo the pronistesont or disolplino tho noro tho ouporlar pupll ic eturalutad to porfarm up to 
the prandse of hls intolil anoo.

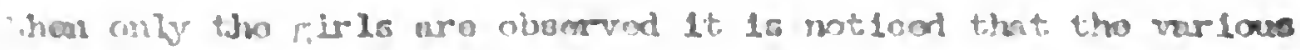

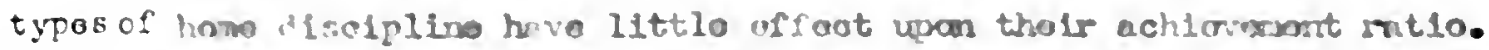

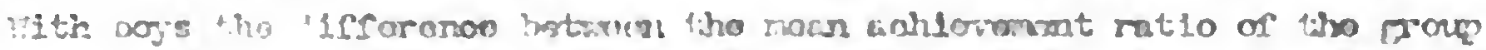

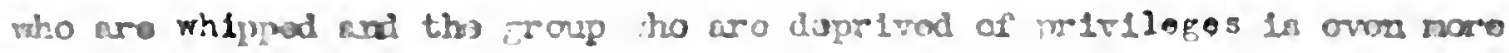
Drapanucerl in Mres of tho parmor.

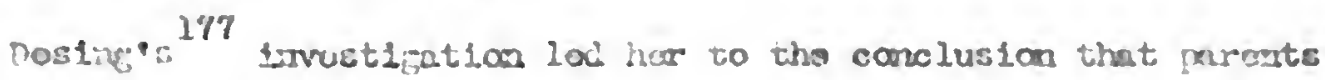

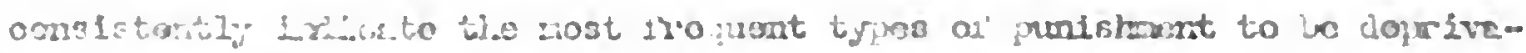

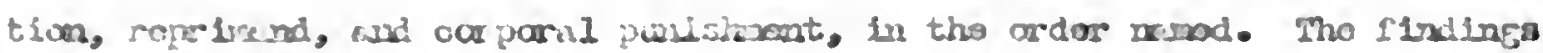

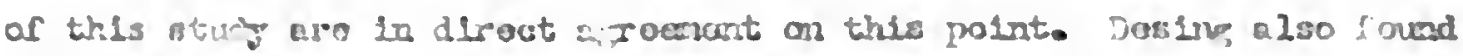

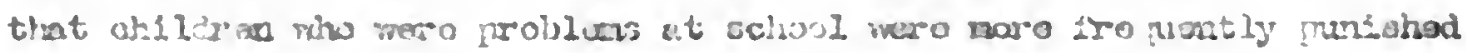

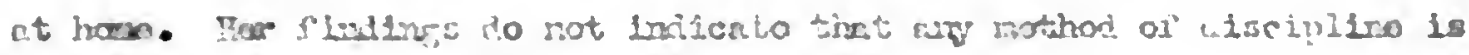
assuelatol. rith mpericr achior:croont. 



\section{TALIE 47}

DISIRIBUTION OF ACHILVEZHW' RATIOS ACCORIING TO hOUL

DISCIPLINE, GIVING THE LERNS FOK WOYS NOD GIHLS SLPNRATBIY

hi evement

Rat1o

HOWE DISCIPLING

NhIpping

Deprivation of Privilegos to 19

to 9

to 0

s to -10

9 to -20

9 to -30

I

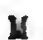

rlo $N$

$\mathbf{x}$

N

M
1

10

43

67

48

12

1

7

3

10

$-4$

1

$-15$

9

$-3$
144

$-9$

79

$-\theta$

65

$-7$
$-5$

37

$-9$

30

$-4$
1

10

17

10

2

1

6

19

10

83

11

3

40

36

297

$-6$

$-7$

$-7$

18

19

154

$-7$

$-9$

$-9$

22

17

143

$-1$

$-4$

$-5$

$F($ total f,roup $)=8.546 . p=.01-$ 
. 


Tha achinement ration for tho pu,ile aro can,arod uniar those headlngs: puplis whose fatharo anly aro morlinf, pupllo moco mothors only are worline, punils whose wothere snd fathers both are waskine,

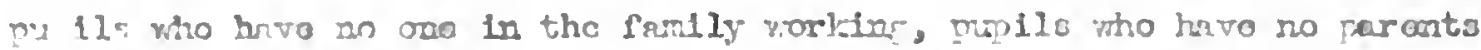
but rolativos morisin, and the puile rito hevo both parents ard relatives working. Frblo 18 indicatos thut the distribution is sloorrod to tho lart for both iojs wa firle as :oll as the totnl Eroup.

Tho fi tost for this reiablousuip yiudiod \& value of 2.126 which is not significant.

For all of the above listed clasalfiant lone fran horsos lus which no ono is sorkinf; to homes in which parents and nue or noro relativos

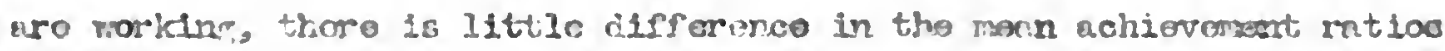
of the proums. As illustratod in Fifure 34 tharo is no rolationship oithos

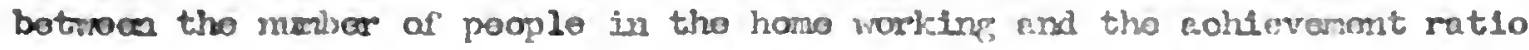
for tho from as a vholo as voll ab for thry and Girls.

Tro Iluotiation in moan echiermint ratio for somo of tho catororios shoven where ofther boys only or pirls only noro conelderod ray bo disconntod bocauso of tho paucity of cksos in thoso ontororios.

Apporontly. whother ar not ovoryiudy noisaty in tho fonily,

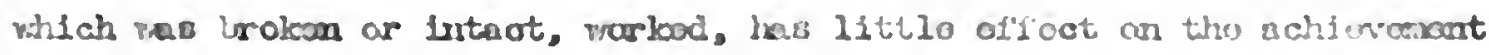
ratio of the propils studiod. 



\section{TAHLE 48}

'DISTRIBUTIOS OF ACIIIEVIIENT RAIIOS ACCOKDDIG 2O

PARETTS WORKING, GIVING IFIE HEMS HOK HOYS MD

GIRLS SITARATERY.

PARETIS WORKIIC

hi ercont

\begin{tabular}{|c|c|c|c|c|c|}
\hline None & $\begin{array}{l}\text { Father } \\
\text { only }\end{array}$ & $\begin{array}{c}\text { Nother } \\
\text { pnly }\end{array}$ & $\begin{array}{l}\text { Nothor } \\
\text { and } \\
\text { Father }\end{array}$ & $\begin{array}{c}\text { Relutive } \\
\text { only }\end{array}$ & $\begin{array}{l}\text { Parent } \\
\text { and } \\
\text { Relative }\end{array}$ \\
\hline
\end{tabular}

Total

Futher

to 19

2

2

to 9

$3 \quad 23$

1

3

16

49

to 0

$8 \quad 73$

1

11

8

47

148

to -10

$4 \quad 37$

3

4

28

82

to -20

1

1

10

to -30

2

1

I

142

6

19

18

$\Re$

294

u

$-7$

$-7$

$-7$

$-8$

$-7$

$-7$

1rls If

74

10

47

152

u

$-10$

$-8$

$-3$

$-10$

$-9$

$-9$

$-9$

688

10

47

142

u

$-6$

$-15$

$-5$

$-3$

$-5$

$-5$

$$
F \text { (total eroup }=2.126 \cdot p=.05_{t}
$$






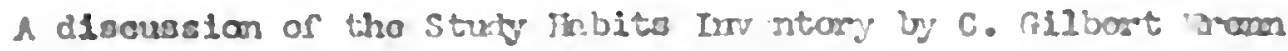
ho nirond boon includal in Chaptor II, P. 51. irLafly, tho iram stab

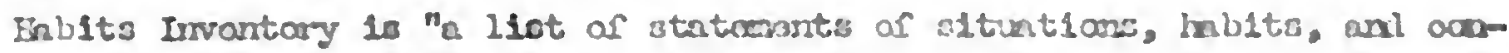

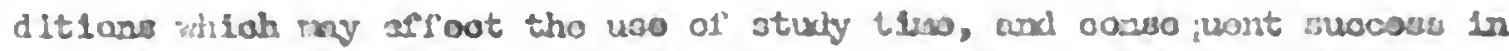
sahoal worle nat stuxty. "178

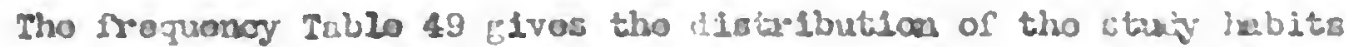
scares for the 297 puplls otudiad. Tho dlatributton npironahno a noral

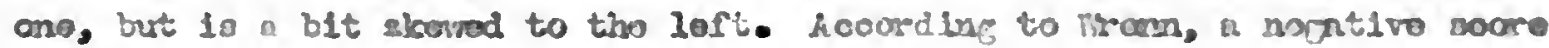

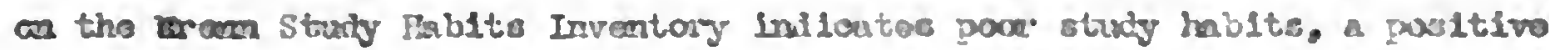
coce indlesios good study laists, and a himp positivo sooro indicateo vory

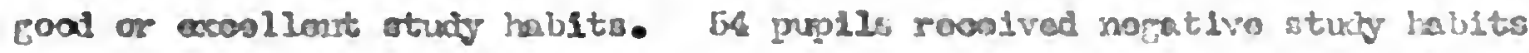
scoros, while tino rominder (245) rocalvod positivo uturly habltw scorus.

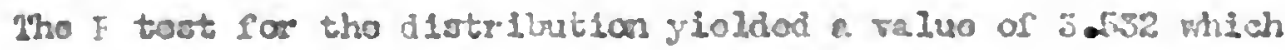

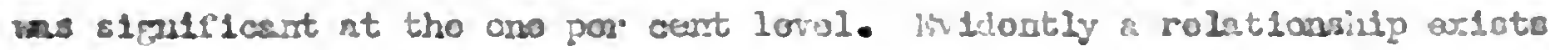

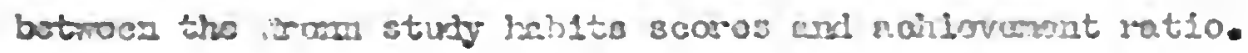

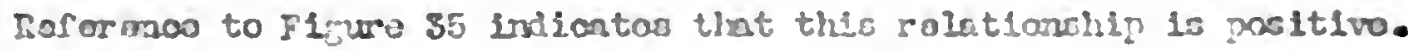

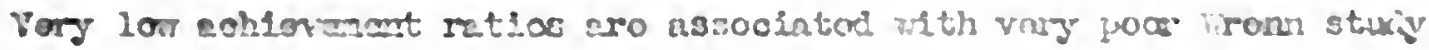

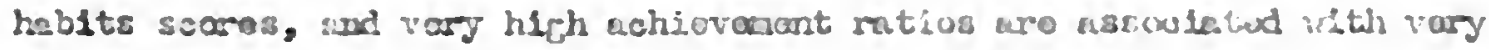

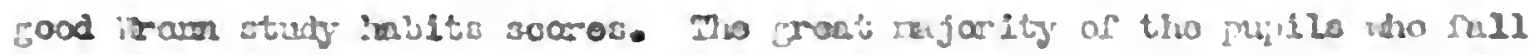

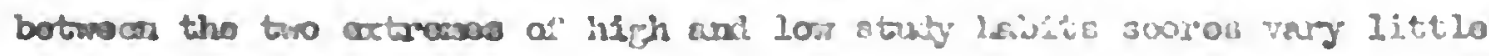

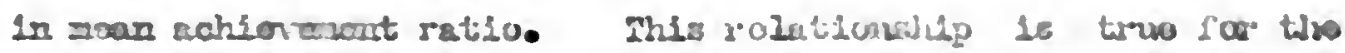





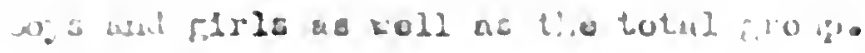

1. ure $\$ 5$ and Toblo 4! show ratior olearly that the rugorlty of

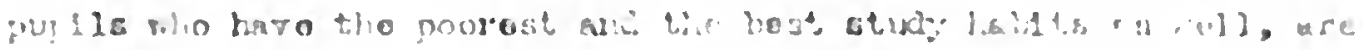

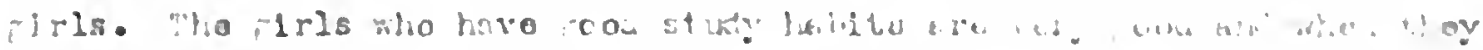

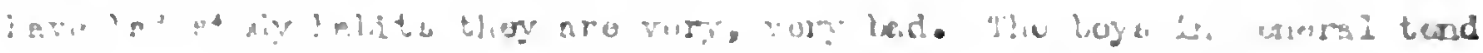

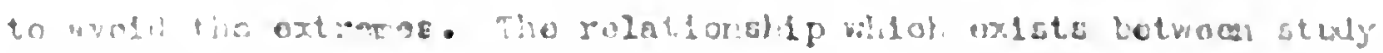

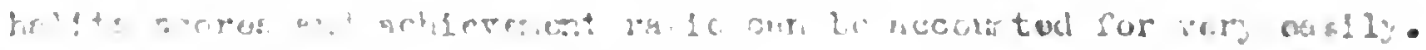

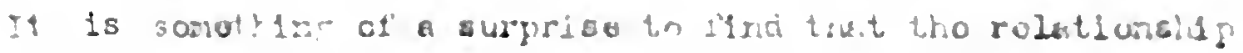

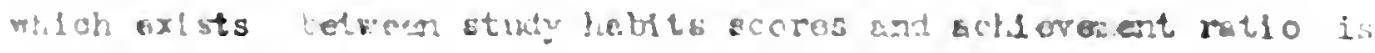

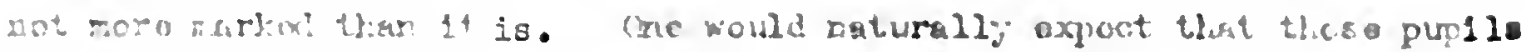

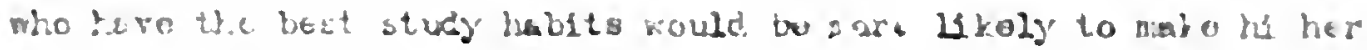

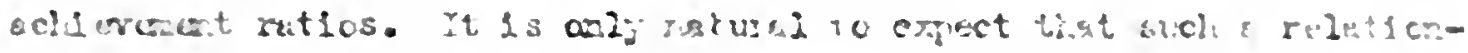

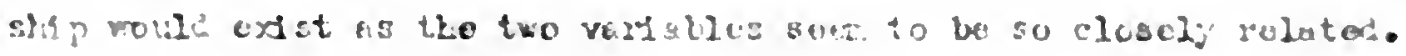

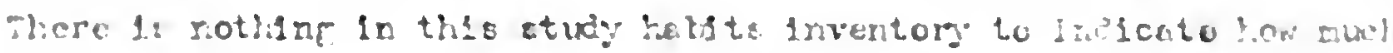

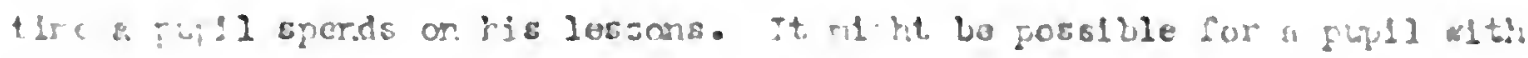

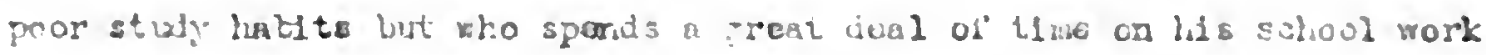

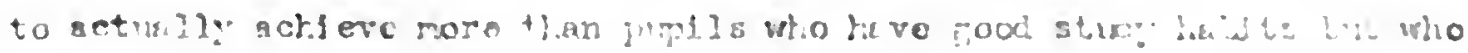

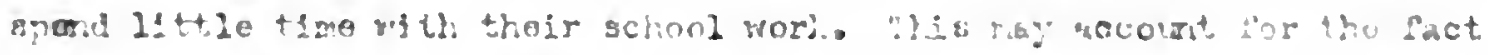

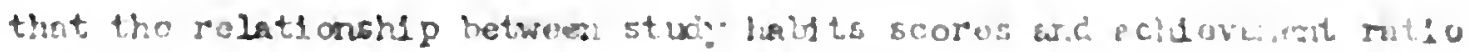
Is not soro : arias thur. 1t is.

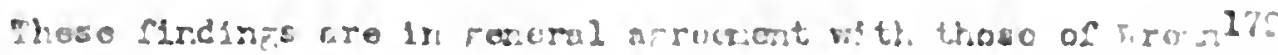
and nesin., 180

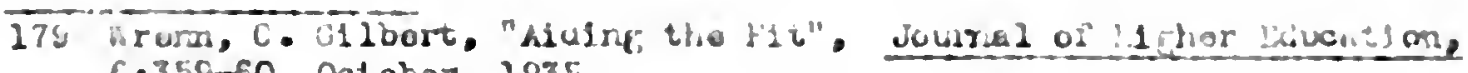
C.359-60, Ort obor, 2935.

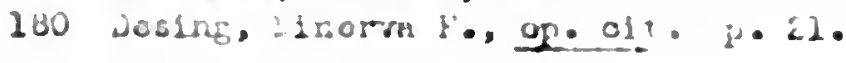


营 韋里果 m

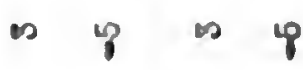

总 요 N $\infty$ 9 P 1 i w
व.
(n)

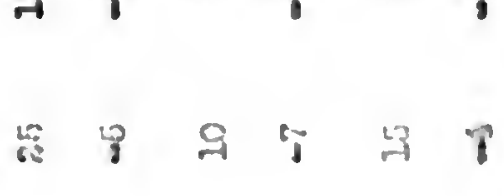

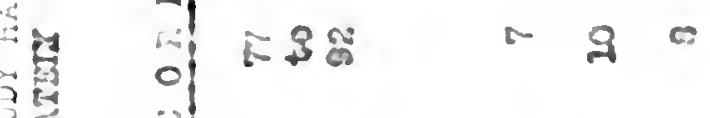

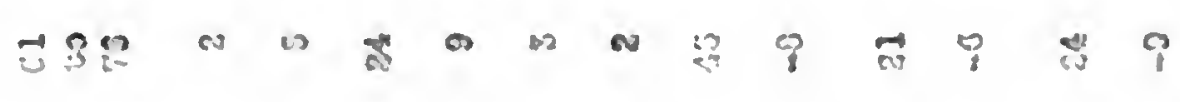
जी

sit

的

c 叟

㩆

承

mi

$=1598$

$\infty 2 \stackrel{2}{2}$

尺:

$\div$

ง

․ 8 औ

की 94

-

(1)

猔

है

군

$3+3$

मे त

采 8 क

$=\frac{1}{40}$

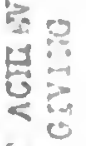

(3)

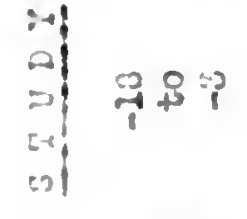

$\therefore \quad 900$

8

$=4 \quad 9$

है

है

it

的

車,

站施

$\because$ से 89

क जै

$\rightarrow$

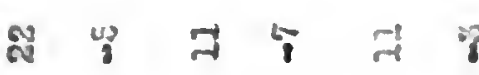

水

ind

3 요요

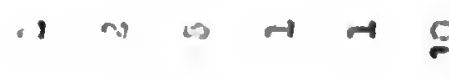

$2 \dddot{1}$

$\infty \stackrel{7}{7}$ c:

है

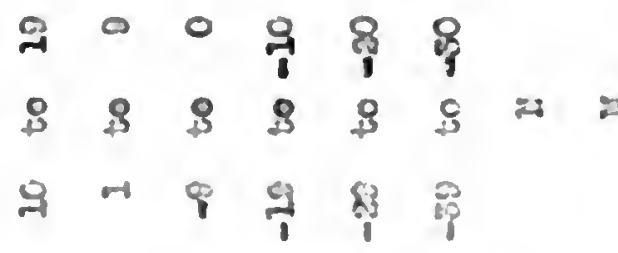

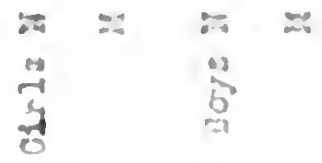





VII CONCLUSIONS

1. Sumary of the Rolationships found betwoen Achiovorient Ratio and tho Lxpurinentul Vuriables.

B. Implioations for Further ReBearoh.

C. Bibllof,raphy. 


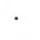




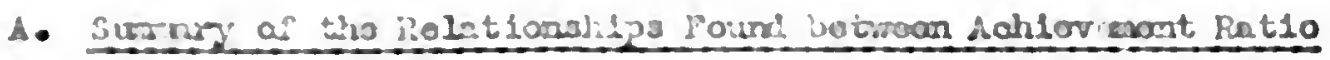
nind tho Esporisiantal Vorlnilos.

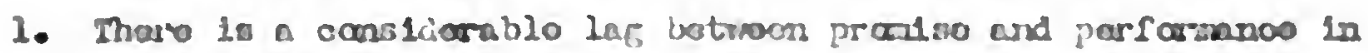

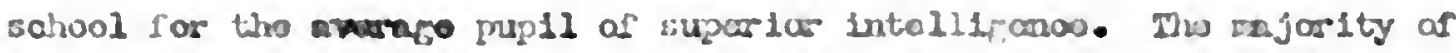

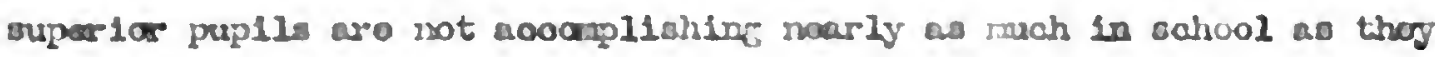
uro ablo to woomisish.

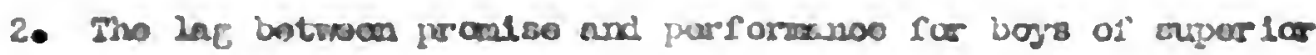

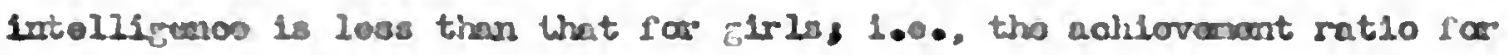

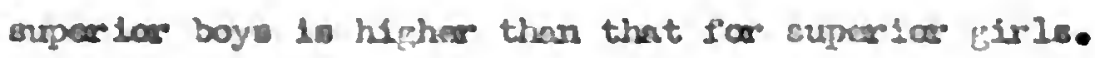

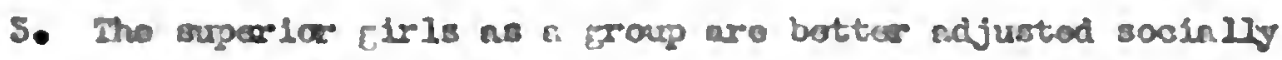
and cosotiomily thens aro the supporiar boys.

4. Ior nahiovenont ratio 18 eesociated with internodinto, average,

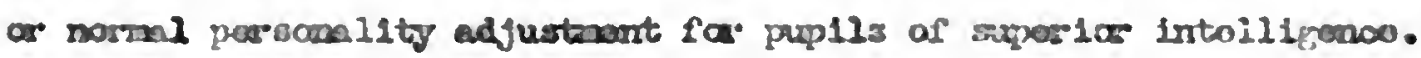

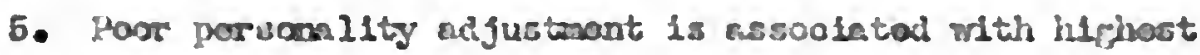

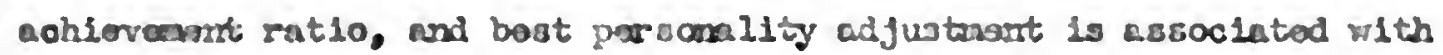

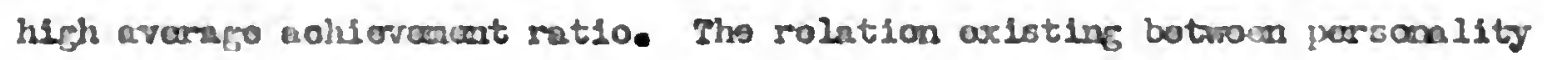

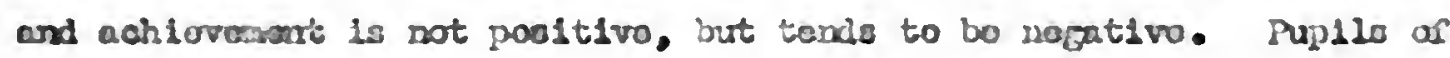
supar or Intollifanco who havo roll adjustod porsanalitios havo an

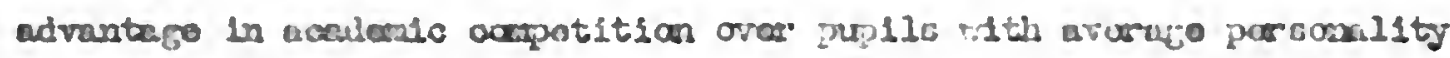

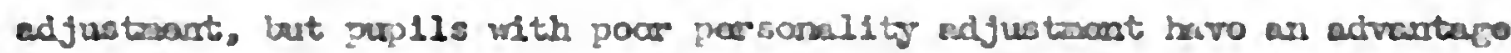

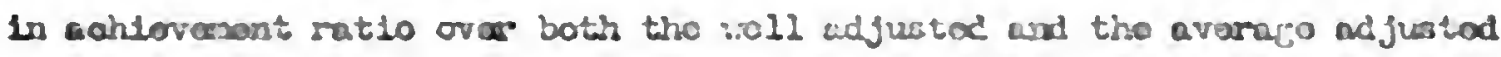
zrouge.

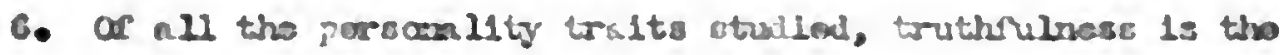

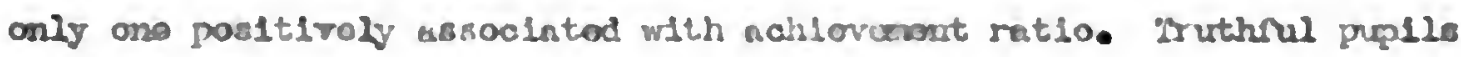

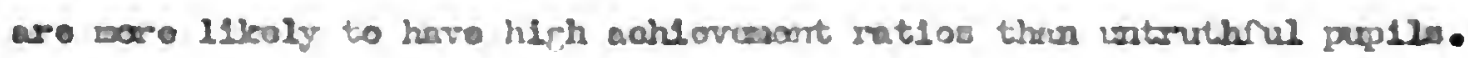


7. The relations to aohleveriont ratio of such poraonality traits as

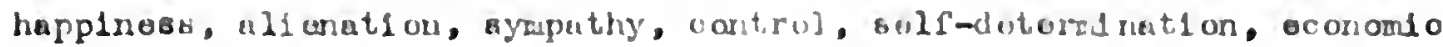
self-dutorination, and purticulneily ndustnond to thu opposito sax tol tend to be nogativo for suporior punils.

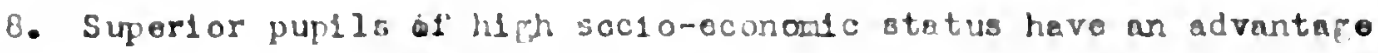
in achievement ratio over pupils of low socio-oconamio statue.

9. Ihe laz betweon promise and performance of 8 upertor piml18 of forelgn extraction is less than that for puplls of native extraction.

10. Pup1ls in whose homes forelgn languages are spoken have an advantage in aohievement ratio over pup1ls in whose homes only phellsh 18 spoken.

11. Puplis whose antecedant were born in Poland have, in goneral, an advantage in achievement ratio over pupils whose anteodents were borm in Germany, Russia, or the United States.

12. In General, pupils whose paronts and grand parents cano from forelgn countries consistentiy exceed the moan achievement ratio of pupils whose parents and erandparents oamo from the United States.

13. There 18 a positive assoolation betwoon aohievement ratio and the amolnt of formal education of the pupila fatiner. Th1 a asooistion adsts bu* $1 i$ is not so woll narked for the anount of formal education of the pupil's mother.

The relation between ohlevement ratio and parents oducation 18 muoh grouter for girle thun it is for boys.

14. Superior pup1la from small famllos of one or no atblinge havo an ajvantago in ahlovenent ratio ovor pupd is from larco ianillos. 
, 


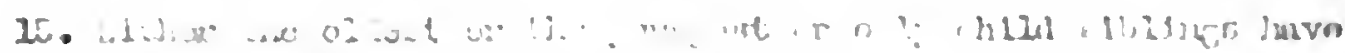

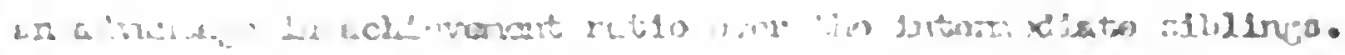

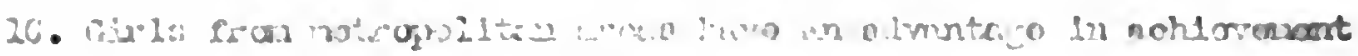

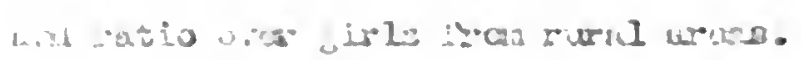

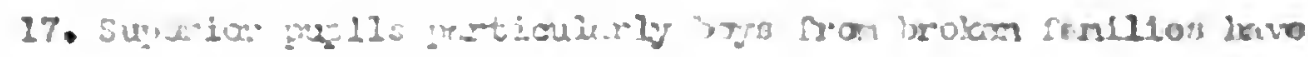

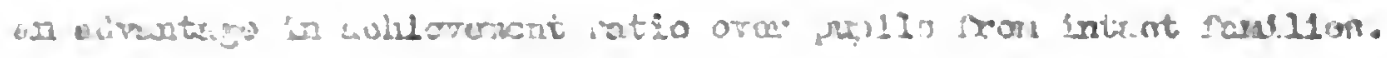

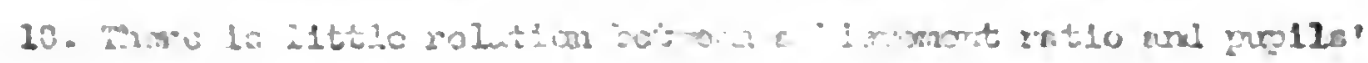

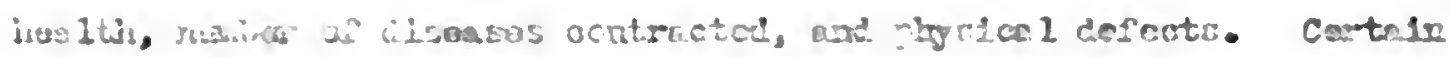

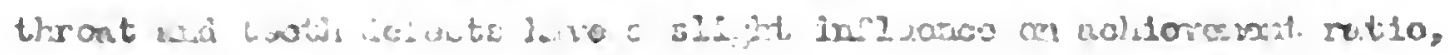

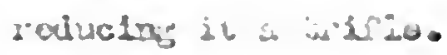

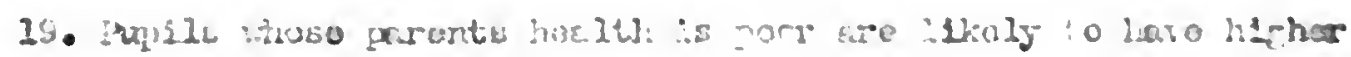

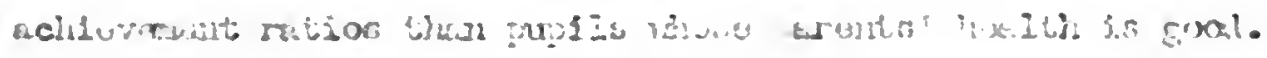

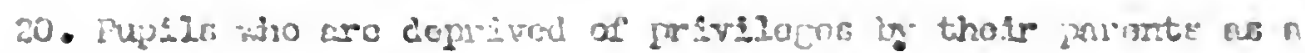

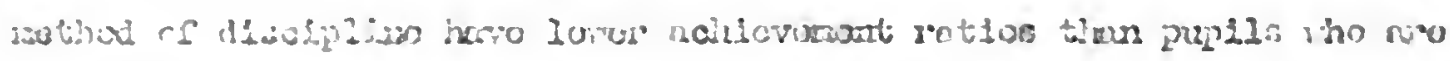

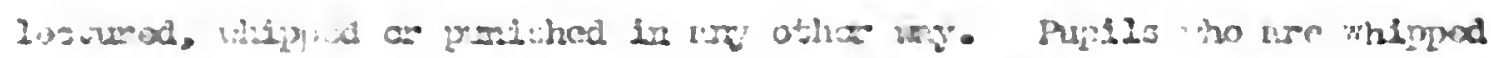

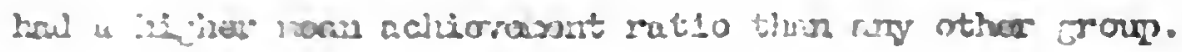

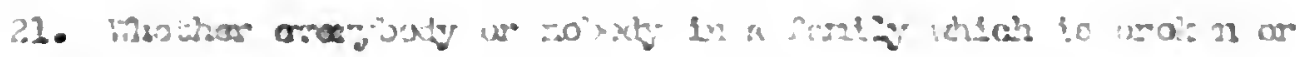

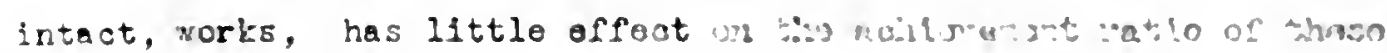

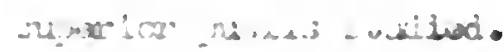

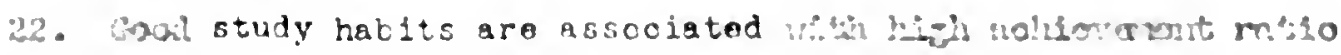

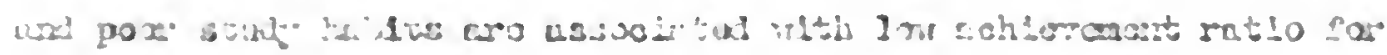

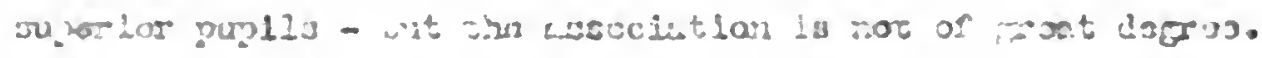

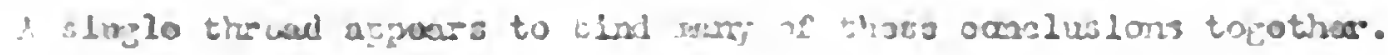

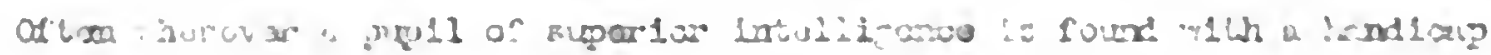

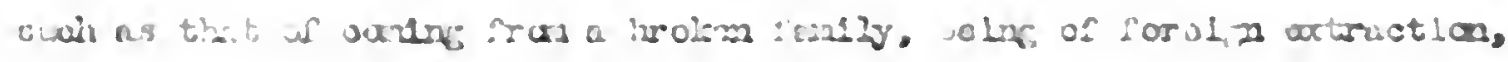

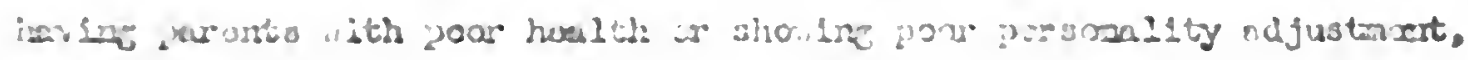




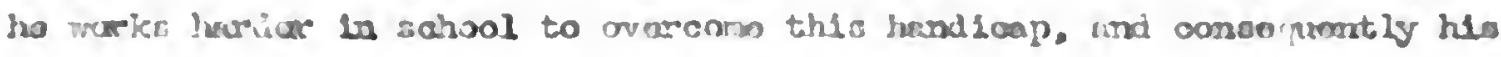

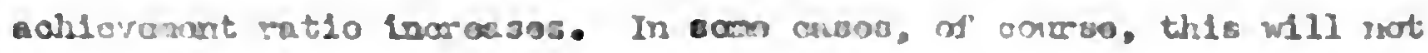

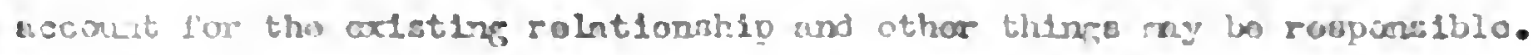
2. Imol1cot1ang rar Further Fosoarah.

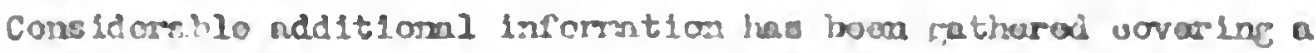

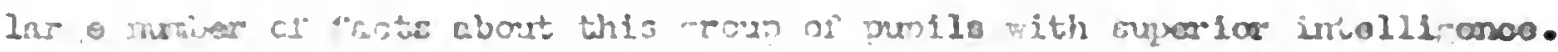

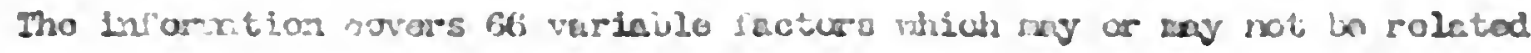

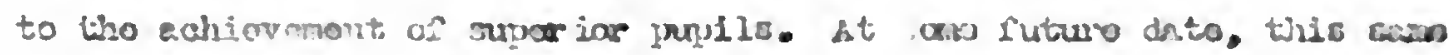

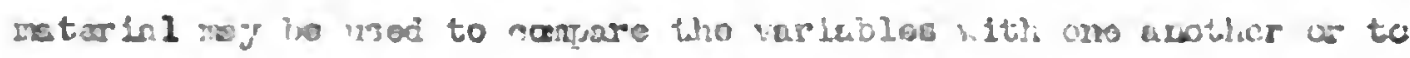

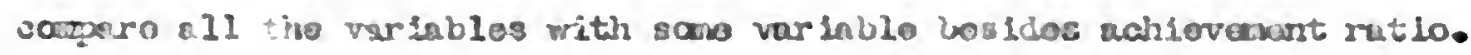

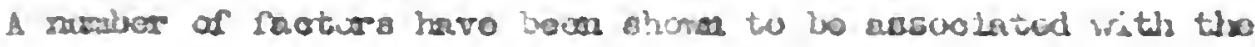

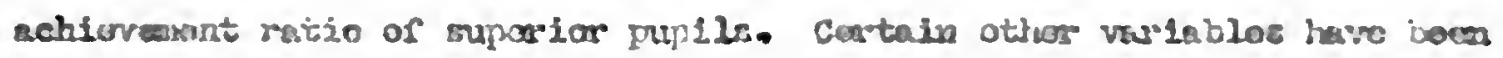

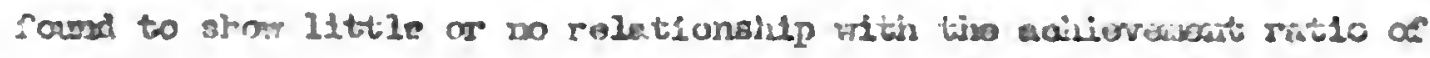

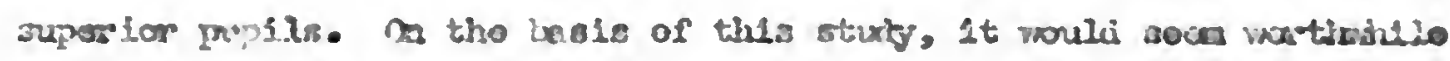

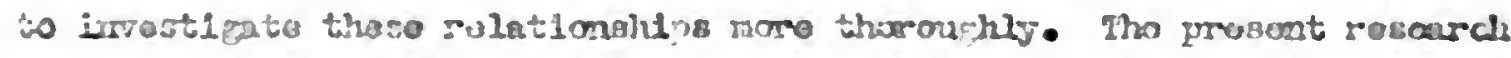

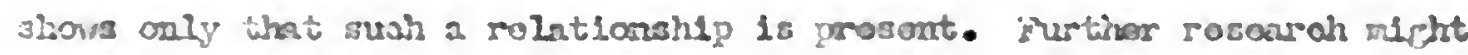

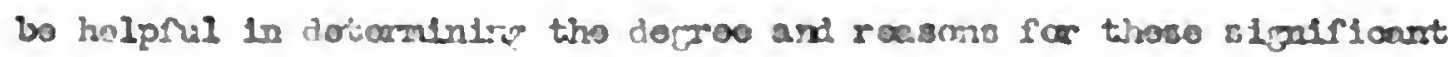
relationshios.

othor irrostiptare any bo intorastad in pursulne tho Irrustipation

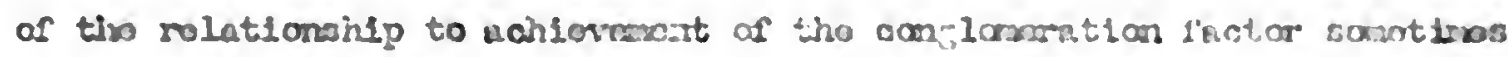

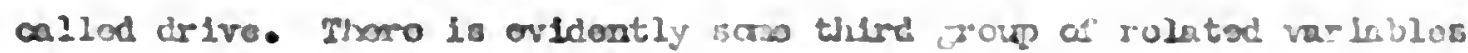
boaldoe Intol11;enco and parsanality thloh has a diroot aflect un wio

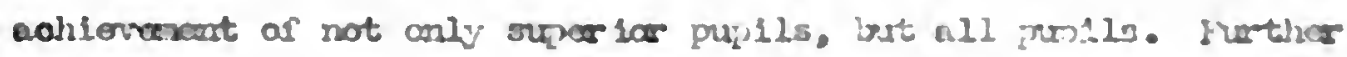

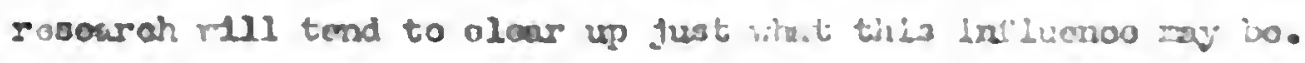

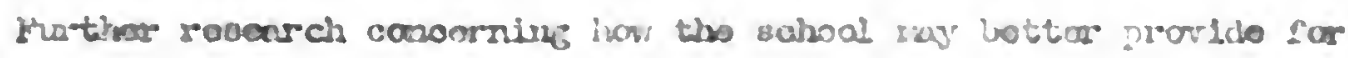

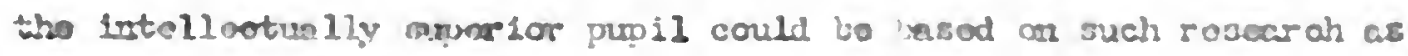




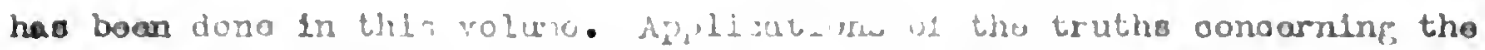
factors nasolatod with paod nohlavant of isuparior puptls would bo holprul. Tho sohool would not only like to lnow vitut frotore are assoolated with tho achloversmt of superior pupsig, int would also I1bo to know vint propres would anoourapo the dovelopmont of thase finotoro positives associatiod wh aohloromont.

The pupil of suparlor intolliganoo dosorvoo spoolal attontiom. Particularly in a dericcracy, tho general lovol of loarning of tho population is $\mathrm{MC}$ botter than the levol of tho intallootual lasdors. Tremondous afforts havo beon mado to imrovo tho achlevemant and loarnims lovel of tho lower ability groups an so to bring up the average loval of tho whole population. This is very dosirables but the sano attantion, If given to pupils of suparior ability, would yield reoults tonfold in value. The fortile soil of the superlar ahild should not bo noflootod for the stomy land of the low ability ohildrem. Fo are never any bottar than our leaderB, and wo should loarn to train our vest to be leadar. Finlo. 
. 
1. Anowymous. "Charaotoristios of Suporior Studento." H.E.A. Rosoaroh Bullotin, 19,158-162, Soptombor, 1911.

2. Baoon, Franols Lo "The Study Babits of Broollent and Doflolont Pupile." Bulletin of tho Dopt. of Soo. Sohool Principale, 40,107-115, Laxhh, 1932.

3. Bakor, Harry J. Charactoriatio Difreronoos in Bricht and Dull Pupllo. Publio Sahool Pub. Co., Bloculafton, III., 1927. 118 pp.

4. "Baltinore Program of Eduation for Puplis of Suparior Ability," Baltimoro Bullotin of Eduotion. 18:1-46. Sopt.-0ot., 1940.

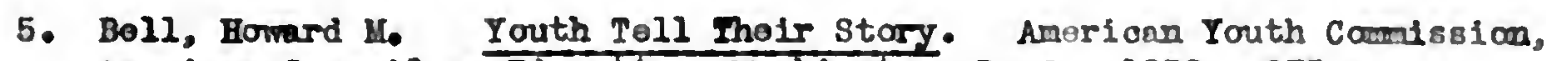
Anerioan Covmoil on Education, Washingtom, D. C., 1938. 275 pp.

6. Bentloy, John Edward. Superior Childroz. W. W. Hortan and Company, How York, 1937. $331 \mathrm{pp}$.

7. Bolzau, Lom Le "Lothods Usod vith a High Abliity Group." Soolal Studies, 29,255-258, Dotobor 1938.

8. Burks. Barbara Stoddard and othors. The Pronise of Youths Follor Up Studios of a Thousand Giftod Childrens Ganotio Studies of Crenius 3 . Stanford Iniversity Proos, Callfornia, 1930. 508 pp.

9. Bursch, Jame F. "How and Comrumity Conditions Relatod to Pup1l Lin ladjustmont." Porsonality Adjustmont of the Elomontary School Ch1ld, Rat1. Elan. School Principal, Bull. of tho Dopt. of Elomb School Prin., B.BA. 15.320-323, July, 2936 .

10. Clark, E. L. "Family Bacloground and Collogo Suooess," School and Sooloty. 45 :237-238, Fobruary 19, 1937.

11. Cahon, Holon Ioulso. "Tho Program for Giftod Pupils in New York C1ty." Engl1sh Jourma 1, 26:548-556, Soptomber, 1937.

12. Conklin, Agnos. Fasluroe of Bighly Intoll1gont Pup11s, A Study of Thoir Bahavior by Hown of tho Control Group. Toachors Colioge, Coluato Univ., Coluenbia Bur. of Publiaations th92, 1940, $250 \mathrm{pp}$.

23. Cox, C. $\mathcal{L}_{0}$ and othors. Tho Early Tratts of Miroe Fundrod Goniuses: Gonotio Studios of Gonlus 2. Stanford Univaroity Pros, Californla, 1926. $842 \mathrm{mp}$.

14. Coy, Gomorlovo. Tho Intorostc, Abilitioo, and Aohiovanont of a Spocinl

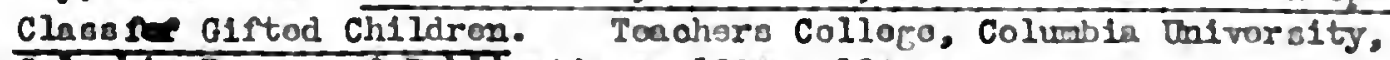
Coluesta Bureau or Publiontions, 1923. 191 pp. 



\section{BIBLIOGRAPII (oontimod)}

15. Dosing, linorra F. Tho Rolation of Cortaln Pupli Aohiovmont Gains to Cortaln Porsomal and Enviramontal Llomonts. Univor 1 ty of Pormoylvania, DIssortation, FhIndolphia, 1940, 169 pp.

16. Douclass, Barl R, and Corpbell, Ina. "Fuotors Rolatod to Failuro in a Mimoapolis Jumlas Hith Sahool." Elamantary Sahool Journal, 37,186-189. Novambar, 1936.

17. Drako, K. J.. Roslow, S., and Bannott, G. K. "The Rolatlonship of Self-Rating and Classmate Rating on Porsonality Traite." Jourmal of Evorimontal Education 7,210-213. Larch , 1939.

18. Ecbort, Ruth E. and L4116, Howry C. "Pattorns of Hifh School Performanco." Studies in Articulation of Righ Sohool and Collogo, Univorsity ar Buffalo Stud100, Sorlos 2, Vol. 13, 10. 4, 1936. pp. 127-180.

19. Ealoart, Ruth E. and Mi118, Honry C. "Variations Amons High Sohool Sentors in Prandse and Parfarmanoe Hbasures." Sahool Revier, 44, 274-282. April, 1936.

20. Finch, F. H. and Hemrok, C. L. "The Rolationahip of the Berroroutter Personality Invontary to Scholastio Achievenant and Intolligonoe." School and Socioty, 36, 592-596. Jovonaber 5, 1932.

21. Prancis. Kennoth V. and Filmore. Bva A. The Influence of Foviroment upon the Parsonality of Childron. Uaiv. of Iowa Studios 10 ChIId Falfaro, Vol. 9, I0. 2. 26y 1, 1934. 186 pp.

22. Gohman, A. I. Factors othor than Intolligonce Portainine, to School Succoss." The Now Doal in Eduoation, 2lat Amual Schoolmon's Procoodings, onivorsity of Poren. Bullatin, 28,3015307. 1934.

23. Goddard, H. H. School Traintar of Olftod Childron. Forld Book Co., Yonloors, H. I., T928. $226 \mathrm{pp}$.

24. Griffitts, Charlos H. "Tho Influonoe of Fanily on Sohool Larles." School and Socioty. 24,713-716. Doo. 4, 1926.

25. Haton, Julia L. "Tho Hobby Clubo for Childron with Spoolal olfte." Bduoat1onal Wothod. 18:21-26, Octobor, 1938.

26. Hollingoworth, Lota S. "An Enrichmont Currioulim for Rapid Loarnara at Publlo Sohool 500, Spoyor School." Toechor' Collogo Rooard, 39.296-306. Jamary, 1939.

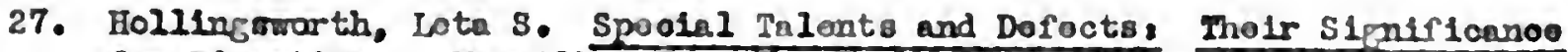
for Education. Kacillar Co., How York, 1925, 216 pp. 



\section{IB IBLIOGRAMII (oont inuod)}

28. Hollin;, wrorth, Lota S. Giftad Childrnn: Thalr Mature and Thurtwre.

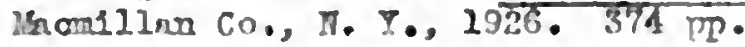

29. Hollingarorth, Iota 6. Spooial Tulonta and Dofoots. Leomillan Co., I.I. 1223, 216 pp.

50. Jonos, Edvard S. A Chartor far the Suporior Student. Univorsity of Bufralo Studjag, Vol. 10, Wo. 3. Buffalo, N. Y. Jnnuary. 1936. 87 pp.

31. Jonos, Harold E. "Rolatiomslips in Phyciunl and Hontal Dovolopmont." Rovion of Eduartiomal Rosaarah, 9:97-102, 134-137, Iotruary, 1937.

32. Koal, Honry H. "Mantal Ratings, Scholarship, and Honlth." Sahool and Soolety, 28, 277-280. Soptomber 1, 1928.

33. Lamphear, Prudenoe T. "What Cloveland is Doing for Suporiar Pup11s." Beflish Joures I, $26,723-728$. Norembor, 1937.

34. Windquist, E. F. Statistical Analysis in Eduoational Rosearoh, Houghton, Mffrin Co., Ilet York, 1940. $266 \mathrm{pp}$.

85. Ink, R. C. "A Test of Four Perbonality Traits of Adolesoonts." Jourzel of Appliod Psycholosy, 20: 527-534. 1936.

36. IInk, H. C. and othors. Inventary of Aotivities and Interests (for boys and young non, for firls and young womon.) Tho Psyohological Corp.. Jor York. 1938. 4 pp. ea.

37. Link, I. C. and othors. Mamual for tho P. Q. or Por Bonality Quotlent rest (Irventory of sotivition and Interests). The Psycholorical Corporation, How York, 1938. 14 pp.

38. Luad. Froderick .1. "Box Difforences in Typo of Educational whotory." Journal of Educational Pzycholopy, 33, 321-330. 15ay, 1932.

39. Herrill, Waud A. "Tho Sipnificance of I. Q'G on tho Rovisod Stanford-Binot Scalos. Jourmal of Education Psycholocy, 29,641-651. Dooombor, 1938.

40. Hyer8, Charlos E., Ruch. Gilos M. and Loofbourow, Grabrim C. Wrars-Ruch H1Eh School Progrose Tost: Form Am. World Book Co., Yonkars-on-Fudson. H. Y. 1938. $8 \mathrm{pp}$.

41. Lvers, Charles E., Ruch, Giloc H. und Loof oourow, Grahan C. Wvars-Ruch High Scl.ool Progross Test lenual of Dirootions. Fiorld Book Compand. Yonkors-on-thudoom, 11. T. 1938, 8 pp.

42. Wonros, Whitor S. Enoyolopaedla of Lducetional Resonroh, Bacillan Co., Now York, 2344 pp. 



\section{BIBI,IOGRAPIX (oontimod)}

43. Osburn, T. J. and Rohan, B. J. Friching tho Curriculion for Giftod

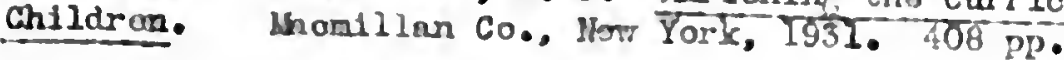

14. Patorson, Domild G. Pilve1quo and Intolloct. Tho Contury Cowquary.
Now York, 1030. 30s pp.

45. Tryma, Arthr F. nnd Porry, Jamas D. "Tho Intoli1gonco handinc; of soptemar. 1355. Honor Studonte." School and Socioty. 42. 383-384.

10. Paynter, Richard H. nod Blenahard, Phyllia. Eciucational Achlovcmont nf Probles Ch1ldren. Commormealth lund, Now York, I029. 72 pp.

47. PLntner, Rudolph. "Intell1ganco Tosta." Psychologioal Bullotin,
$23.453-472$. July, 1935.

48. Poffembergar, A. T. and Carpontar, Hloronoe L. "Choractor Traltz in

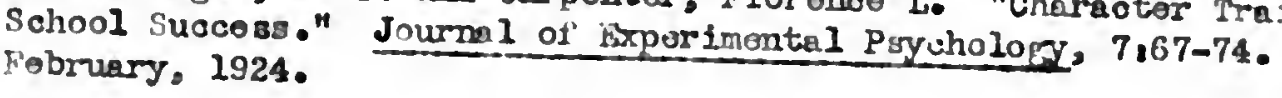

49. Regensburg, Jeamotte. Studios in Educational Suocoss and Fallure
in Suparnomel Chlldren. Itay, 1851, 150 pp.

50. Rothnoy. 3. T. and Roons, B. A. "Applicatlans of Porsonality and Character, Hoasuremant." Roviow of Bducational Rooceech, 11: 91-108,

51. Ryans, D. G. "A Tontativo Stateront of the Relation of Porsistenco Tost Soorog to Cortain Porsons]ity Traits as Monsurod by tho Beranoutor Invontorg" 229-34. Parch, I939.

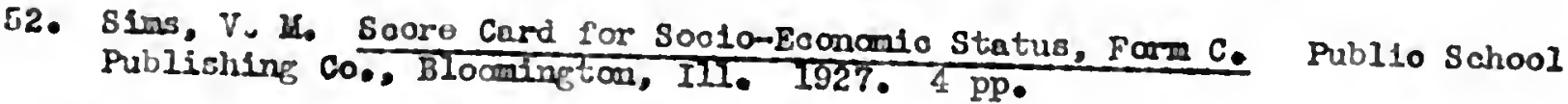

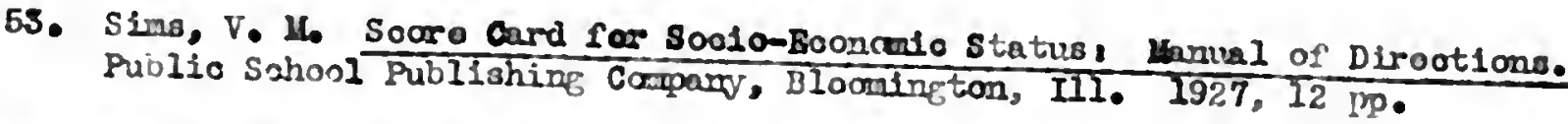

54. Smith, Barry P. "Faotors Rolatod to Acadonto Achiovomont." Praotioal Valuo of Educational Rosoarch, Norican Bducatlonal Rosearah $\frac{\text { Praotioal }}{\text { Roport, pp. 26-28, Lay, 1938. }}$

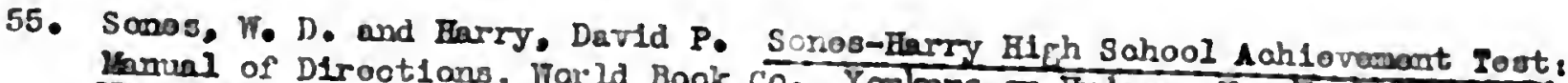

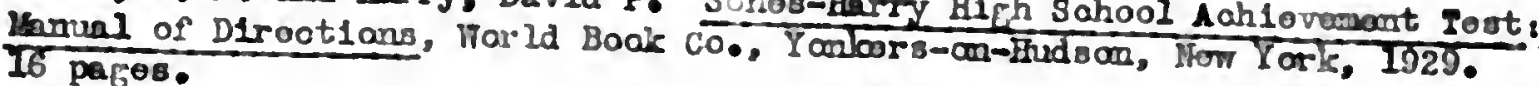

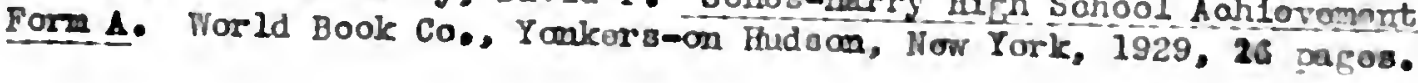



BI BILIOGKNHYY (contInuod)

57. Stapner, Ros. "The Relation of Peroonall ty to Aoudomlo Apt1 tude and Aahloveront". Journal of Eduoutlonal Rosonroh, 26,648-660 May, 1933.

58. Starrack. J. A. "lletchlur, Ability with Acluovoment". Journal of III hor Eduoation, 8,315-320, Juno, 1937.

59. Stedman, Lulu U., Edvoatlon of Gl Itod ChIldron. Norld Book Company. Yonkers-nn-lluds om, how York, 1924. 190 pp.

60. Stoore, Ii. J., "The Effeat of Charactor Tralts on Sclolust1o Aahi ovement". Sohool and Soclety, 29, 707-708. Jume 1, 1929.

61. Strabol, Bunfoo, "Aoadowio Suocess of Varlous Ape and Exporienco croups". Studios in Artioulation of $11 \mathrm{ch}$ School and Collogo. Und versity of Buffalo Studies, Serlos 2, Vol. 13, Bull. 3, 1936.

62. Stroud. J. B., "Applioution of Intell1genco ToctB." Revler of Ejuoat1 onal Reaearch. 11,25-11. Fobruary. 1941.

63. Terman, Low1e L. und othere. bontal and Physlcal irkits of ono Thousand Gifted Childrens Genetlo studies of (ianiug l. Stanford University Press, Califormla, 1525. 646 pp.

64. Thompon, W.A.. "An Evaluation of the P.Q. (Personallty quotiant) Tost". Charuoter and Personal1ty, 6, 274-292. Juno, 1938.

65. Traxler, A. E., "Current Canstruction and Evaluation of Jorsonallty and Character Tosts". Kovi on of Educatlonal Fosearch,11:67-79. Pebruary, 1911 .

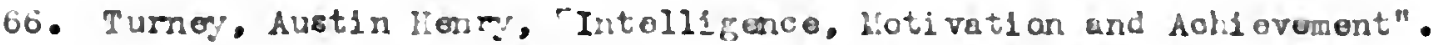
Journal of Educetional Ss:rchology, 228426-434. September, 1931.

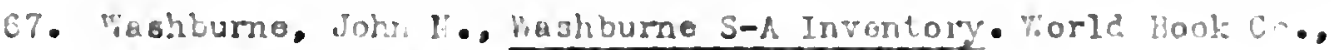
Yonlers-on-liudson, liew York, 1940. $8 \mathrm{pp}$.

68. Vashburno, John $\mathrm{l} \cdot$, Viashburne S-A Inventory (Thagric Edition):

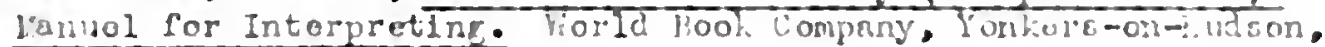
Tow York. 1540. 22 PR.

69. N1111ams, J. Herold. "The Socially haladjusted". Kovi or of" Ealucatianal Reseuroh, 11,238-2yG. huro, 1941 .

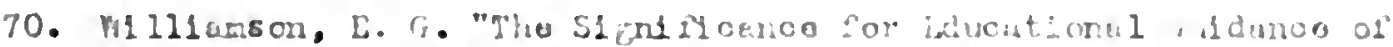
Persockl 191storles". Sohool Rovlow, i4: 41-4y, Jaruery, 1930. 



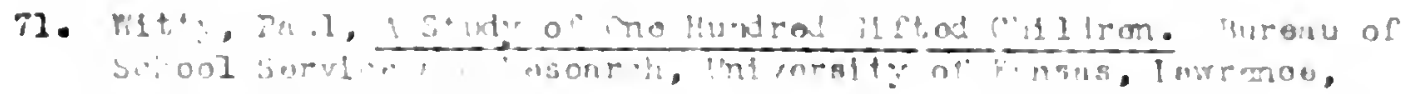

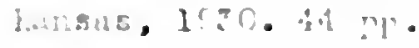

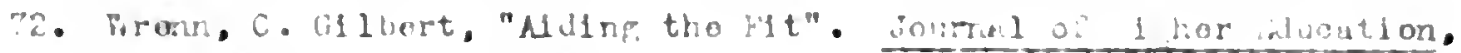
6.357-303. Jetolar, 1235.

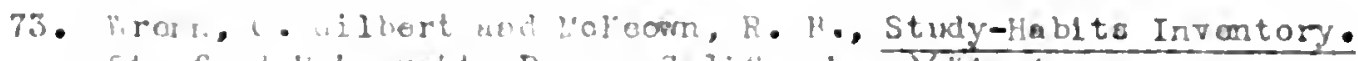

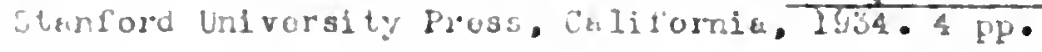

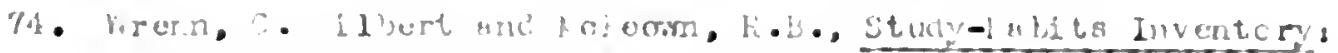
$\frac{141}{104.8 \mathrm{pP}}$.

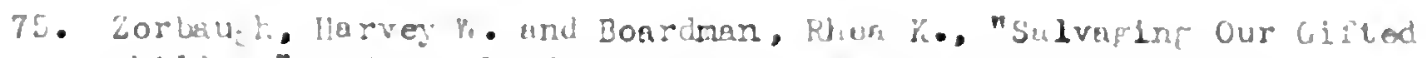

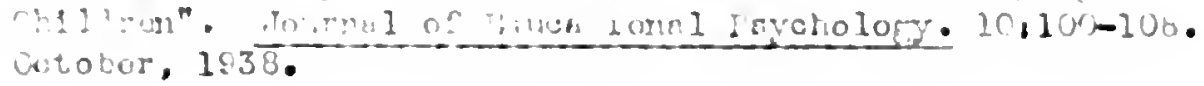



A P P E D I C ES

\section{Questlonnal re}

vita

Kastor Chart 



\section{QUENII IORINAIRE}

1. In what oountry wore you born?

2. In viat router" was your lathur born?

3. In what countr:" was your notbur born?

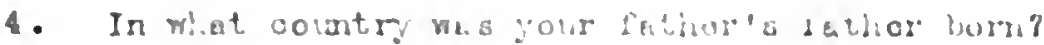

5. In what country was jour fathor's mothor born?

6. In whet cointry was your nother'e futher born?

7. In mint country was your mother's mothor born?

8. Do you I1ve with your mother? your rathor?

9. Do you IIve with any othor relatives besides brothers and 81 aters

10. Are you the only child

11. If not, how muny younger brothers do you havo? h. ow suny older

12. Zov many younger sisters do you have? how suany older

13. In whet place have you opent the ereator pert of your 11 fo?
Balt1moro
a city
a town
the country

14. Fitat forolgn languagos, if any, aro spoken in your hone?

15. What tine consuninf activitios havo you ongagod in outside sohool, such as pald employment, muelo loesone, othor sohool Lri, houblos, play, ohurch work, eto. be spoolflo

16. In what k1nd of rocreational actiritlog in sohool ard out do you on joy participatinp

17. Name plaoes to which you have travellod outside llarylnd

18. Lavo you any phyoloal disablitieg or handionps if wo naru thom

19. What id of books do you lite to read? lo speclelc und olonr. 


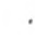


20. What mombor of the foully do you l1ko beet?

21. What menber of tho fandly do you like least?

22. Are your paronts rathor strlot with you whon you do aomothinp, wronp,

23. Do you droam ofton? ocosionally? about the same thing. more than onoe?

24. Do your drooms frichten you? or do you 11ke to droam?

25. Do you da $z$ drenm? winat sobout?

26. Wint church do you belonf to?

27. Do you take a part in church activities? If so list sono

28. Do you 11ko school? Why?

29. Do you intend to eraduate from hiph school?

30. "Iow many half yenrs have you falled? Nime the grados

31. liow meny half yonls have you skipped? "sme the rrados

32. Have you evor gone to sumer gchool? Advaroo ? Roviow?

33. Lave you falled lu any oubjoct since you onturod the ph grado? If so nario the prade und tho gubjoots fallod

24. How many times have you boan cr the homor roll olnoo you antorod the the 78 grade

35. Do you intend to go on to wollage if you oun?

56. What do you intend to do whor :our schoollne $1 \mathrm{a}$ war?

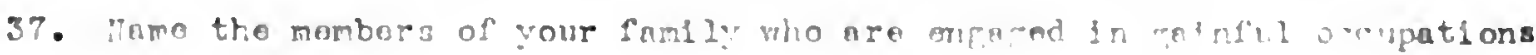

38. How many timos haro you noved sinco you mera horn?

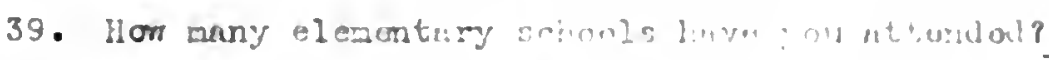

40. How many junfor hipt schools have you thet ondod? 

41. How unny sond n? is haclioolo hivo you attondodi

42. Is your mothor's hoalth food?

43. Is your futhar's heralth pood?

44. Dano tho 111 nossos gou havo had.

45. Do you woar plaseos? Can you soe well?

4C. Do you host wol1?

47. Havo "ou over baon operatad an? ror what?

48. Do you got wlong well with your brothors and olstors?

49. Do your parents got along. all rleht togathar? On spoakine torms?

50. Low are you punished when you displease your paronte?

51. Do you have any bad habits? Nane them

52. Do manbers of your fand ly have had habts? Namo the porson and the habits?

63. On the arerace, how many days a yuar have you becen absent?

54. Hor: many terms in Jurs or and Senlor hich school havo you rocol vod an umatisfactory mark in conduct Erfort?

55. Do you profer mon or women teachera? Why?

66. Name in order of importance to you. flvo tralts of the rood touoher, and rive tralts of the poor tosoher.

Gooc

$\begin{array}{lllll}1 & 2 & 3 & 4 & 5\end{array}$

Poor

57. Huve you evor thought about runding away from homo?

68. If you have boon succoseful in school work, oxplasn what you think has made you suocossful

59. If you ithre ovor falled in school work, l1st hore tho roasons you bollove havo oa ued your rallure 

60. Llst tho part timo jobs you huvo had wilu jou woro attending sohool.

61. L1st the simeior jobs rnu huve had

62. Do you do work around the house for whioh you uro paid? Explu1n.

65. If you havo oarned monoy. do you koop it all yoursolf? ritat hinds of thinis do ycu spund it for?

64. Ir you aro eiven s; endine monoy, how do you spand it?

65. Do you havo a bank acoount?

66. That housohold task do you perform at hono?

67. That grado did jour father flns sh in school?

68. That grado did your mothor flns sh in sohool?

69. Does anyona holp you vith: :ur scliool work at home? Who?

70. What pert of this study do you 11 ko nost and why?

11 ko least and why?

Notes For pusposeo of this study so that a omplato pioture of every pupli may be obtalned, the investipator would 11 ko to have evory quotion completoly 1111 od out truthfully to tho bast of jour abll1ty. If, howovor, for sumo reason you would rathor not answor a quostlon, leavo lt blank. Use the back of the ahoot if you nood noro spaco for un answor. 

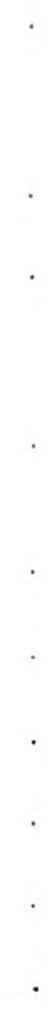


\title{
FOLD OUT
}

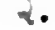 \\ Gama Funn i \\ Gama Form A \\ sore \\ sge I. i. \\ - $(0 t 13)$
}

-Puch Achlovara? soro

-Rucla Standard c $u$ ro

Gatra (Por A) tandard coro

ovemont Ratio ason $=$

.--M. A. Crous

oral 3chol. Ar. op-Fob 1940)

of aubj. Calluros revloun torm 
$(9-10000)$
norcus

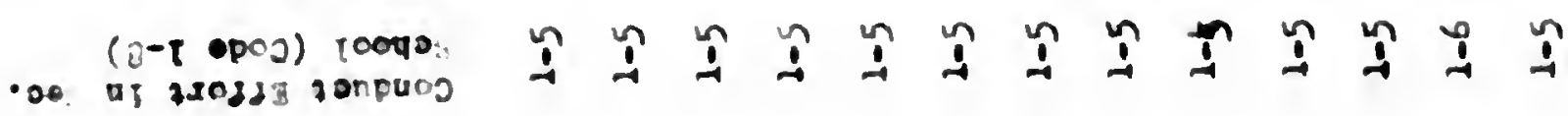

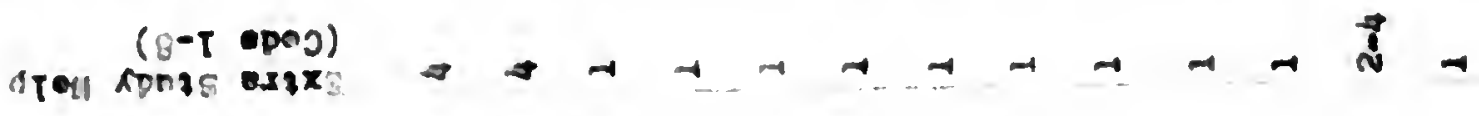

$(S-T \cdot 0,00)$

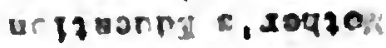

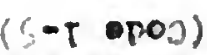

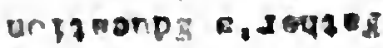

(t-t epos) toonos ut extrai soj urees.

$(L-t$ op j) toopo a) ccooon.; sing sucosets

(t-t opos) $x$ : Bugonal doj eouaragas

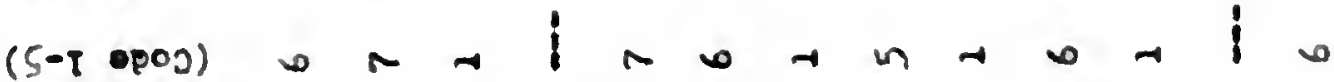

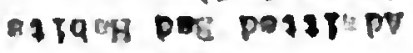

$($ T(5)

$(\vartheta-t$ opos) II Cotropuesig roouof

$(6-1$ opos) II00uepueziY T0040

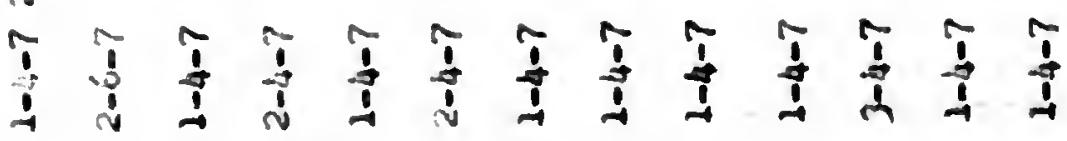

2025050 anc laOs? suecqu okn

$(9-1$ opos)

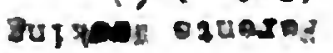

$(L-\tau \bullet p \circ)$ Tooप:

1 n

$1+10.10$

- a $r$

i

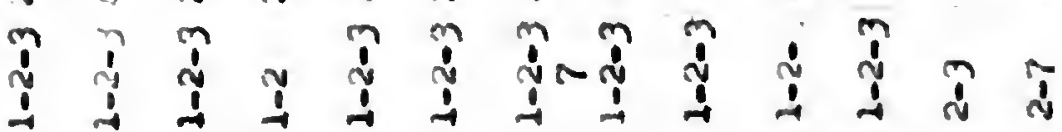

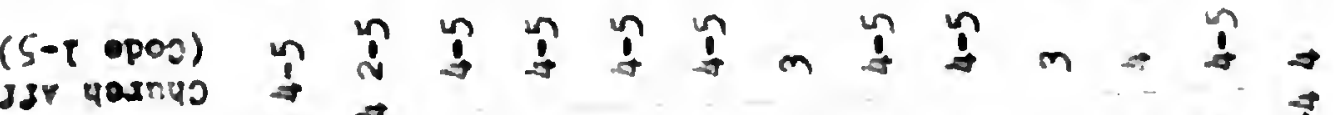

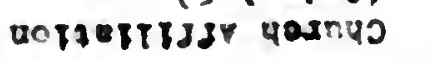

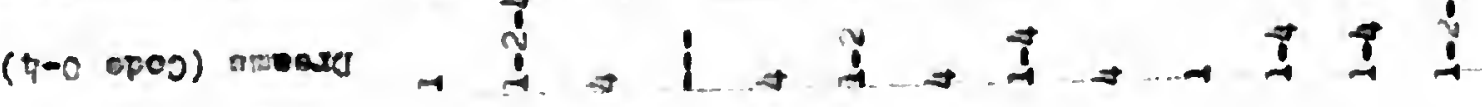

$(S-1$ opos)

matกรos so mot?

i

$m n \sim n N$

(ctepos)

d $+-i ! j+i+\frac{1}{i}$ 
$\underline{P I T \Lambda}$

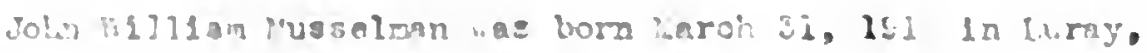

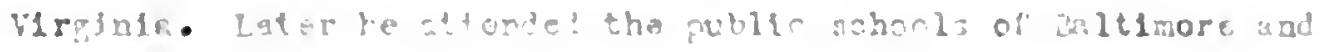

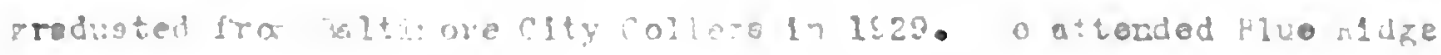

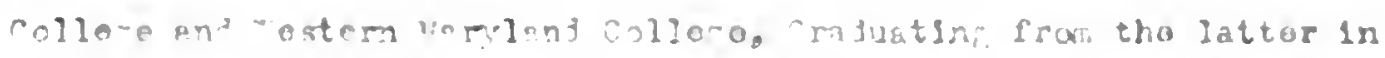

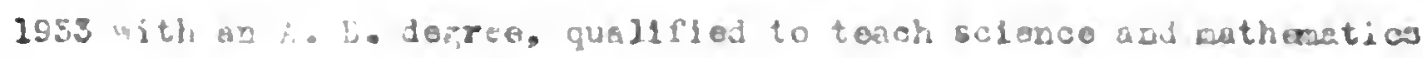

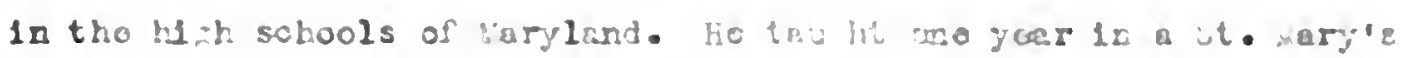

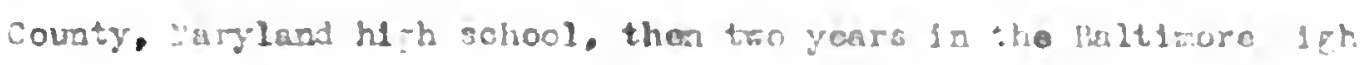
Schools as taschor and athletio coach of boxln end football. Wfer two years na teacher-1n-charre of 5 hator lith school antex, bo vecamo the Prinolinal's weclal Aselatant ond Dean of Roye at. Southem Junlor-

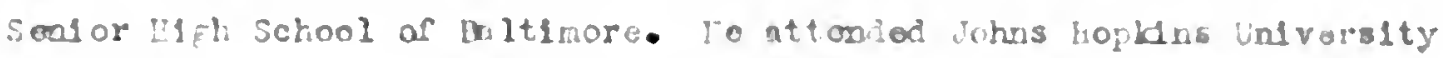
fran the surmas of 1937 untll tho fall of 1942 . Iis arly publlshed work to dato is a eumerary of the dissortation undor the saso t1tlo in tho Journal of ixperinental Educeticn. 





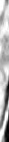




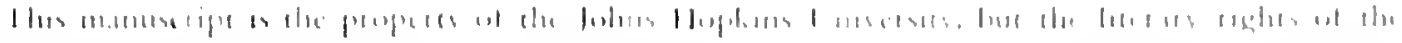

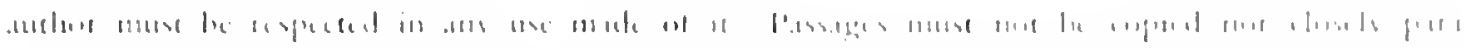

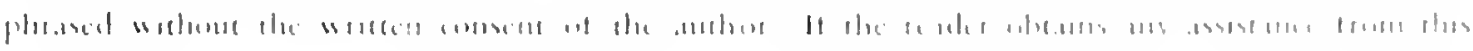

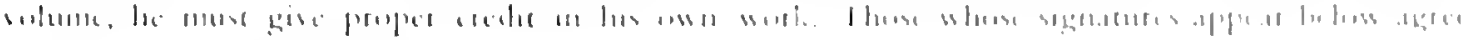

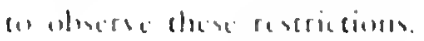


